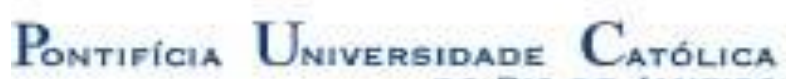

Alexandre Arantes Pereira Skvirsky

\title{
A Introdução Da Dúvida No Ceticismo No Renascimento
}

\section{Tese de Doutorado}

Tese apresentada ao Programa de Pós-Graduação em Filosofia da PUC-Rio como requesito parcial para obtenção do título de Doutor em Filosofia.

Orientador: Prof. Danilo Marcondes de Souza Filho

Rio de Janeiro

Maio de 2015 


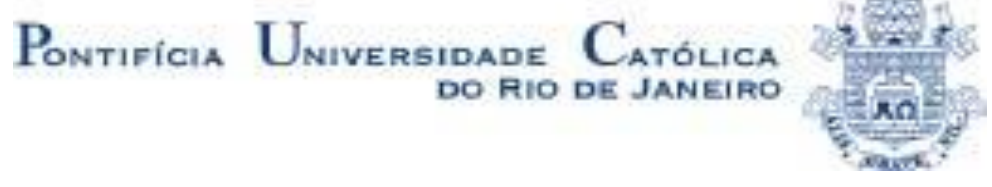

\section{Alexandre Arantes Pereira Skvirsky}

\section{A Introdução da Dúvida no Ceticismo no Renascimento}

Tese apresentada como requesito parcial para a obtenção do grau de Doutor pelo Programa de Pós-Graduação em Filosofia do Departamento de Filosofia do Centro de Teologia e Ciências Humans da PUC-Rio. Aprovada pela Comissão Examinadora abaixo assinada.

Prof. Danilo Marcondes de Souza Filho Orientador Departamento de Filosofia - PUC-Rio

Prof. Rogério da Costa Soares Departamento de Filosofia, PUC-Rio

Prof. Aldo Lopes Dinucci Departamento de Filosofia, UFS

Prof. Rodrigo Pinto de Brito Departamento de Filosofia, UFS

Prof. Cesar Kiraly Departamento de Filosofia, UFF

Profa. Denise Berruezo Portinari Coordenadora Setorial do Centro de Teologia E Ciências Humanas - PUC-Rio

Rio de Janeiro, 20 de Maio de 2015 
Todos os direitos reservados. É proibida a reprodução total ou parcial do trabalho sem autorização da universidade, do orientador e do autor

\section{Alexandre Arantes Pereira Skvirsky}

Graduou-se em Filosofia na UERJ (Universidade Estadual do Rio de Janeiro), em 2004. Concluiu o curso de mestrado em Filosofia pela PUC-Rio em 2007. Cursou o doutorado na mesma instituição, onde obteve o título de doutor em Filosofia com a presente tese. Foi bolsista da CNPq durante o mestrado e o doutorado. Pesquisa na área de Epistemologia, Metafísica, Filosofia Moderna, Ceticismo Antigo e Moderno.

Ficha Catalográfica

Skvirsky, Alexandre Arantes Pereira
A Introdução da Dúvida no Ceticismo no Renascimento
/ Alexandre Arantes Pereira Skvirsky ; orientador: Danilo
Marcondes de Souza Filho. - 2015.
200 f. ; $30 \mathrm{~cm}$
Tese (doutorado)-Pontif́cia Universidade Católica do
Rio de Janeiro, Departamento de Filosofia, 2015.
Inclui bibliografia

CDD: 100 


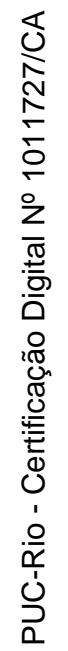

À Beatriz 


\section{Agradecimentos}

Ao meu orientador, Professor Doutor Danilo Marcondes de Souza Filho pela confiança e gentileza com que se prontificou a me orientar e que demonstrou para mim durante os períodos mais difíceis. É uma honra ter sido seu aluno e orientando; foram suas aulas durante o mestrado que me despertaram o profundo interesse pela filosofia cética e me provocaram para esta pesquisa.

Aos professores que participaram da Comissão examinadora, pela disponibilidade e generosidade na leitura, correções, e críticas. Agradeço à Professora Doutora Ana Paula El-Jaick pela imensa dedicação em ler e revisar todo o trabalho.

Ao Professor Doutor Luiz Eduardo de Oliveira Bicca, pelo apoio ao meu ingresso ao programa de pós-graduação da PUC-Rio, e o incentivo conferido desde os anos de graduação.

À Capes e à PUC-Rio, pelos auxílios concedidos, sem os quais este trabalho não poderia ter sido realizado.

A todos os professores e funcionários do Departamento pelos ensinamentos e pela ajuda.

À minha família por todo apoio. Ao ao meu filho pela paciência, ainda maior por não entender exatamente o que era esse trabalho que tanto me ocupava, e à Beatriz Piffer Machado, a quem dedico esta tese. Estar ao seu lado permite questionar, sem medo de se perder em sem sentido, o sentido de todas as coisas. 


\section{Resumo}

Skvirsky, Alexandre Arantes Pereira; Souza Filho, Danilo Marcondes de (Orientador). A Introdução da Dúvida no Ceticismo no Renascimento. Rio de Janeiro, 2015. 200p. Tese de Doutorado - Departamento de Filosofia, Pontifícia Universidade Católica do Rio de Janeiro.

Sexto Empírico não fala de dúvida, e não faz uso deste conceito em sua clássica descrição do cético pirrônico. No entanto, desde a sua redescoberta na década de 1430 no contexto do humanismo florentino e até os dias atuais, o ceticismo é interpretado através da dúvida. $\mathrm{Na}$ presente tese, primeiramente mostramos que não há uma conexão direta entre o ceticismo pirrônico e o conceito de dúvida. Em seguida, analisamos alguns dos modos pelos quais a dúvida é introduzida no ceticismo, particularmente no período que vai do início do século XV ao final do século XVI, conhecido como 'ceticismo renascentista'.

\section{Palavras-chave}

Ceticismo; Pirronismo; aporia; epoche; suspensão; dúvida; certeza; Cícero; Montaigne; Sexto Empírico. 


\section{Abstract}

Skvirsky, Alexandre Arantes Pereira; Souza Filho, Danilo Marcondes de (Advisor). The Introduction of Doubt in Skepticism in the Renaissance. Rio de Janeiro, 2015. 200p. Ph.D Thesis - Departamento de Filosofia, Pontifícia Universidade Católica do Rio de Janeiro.

Sextus Empiricus does not speak of doubt, nor does he use this concept in his exposition of Pyrrhonian skepticism. However, since its rediscovery in the 1430s to the present day, skepticism has been interpreted through the concept of doubt. In the present thesis, we showed first that there is no explicit connection between Pyrrhonian skepticism and doubt. Then, we analyzed some ways through which the concept of doubt was introduced into skepticism, especially in the period from the beginning of the $15^{\text {th }}$ to the end of the $16^{\text {th }}$ century, known as Renaissance skepticism.

\section{Keywords}

Skepticism; Pyrrhonism; aporia; epoche; suspension; doubt; certainty; Cicero; Montaigne; Sextus Empiricus. 


\section{Sumário}

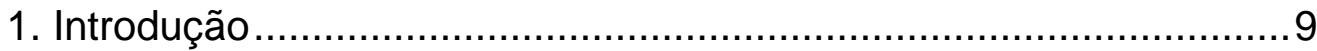

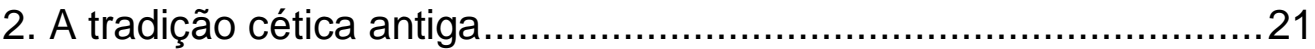

2.1 Breve descrição do ceticismo pirrônico..........................................32

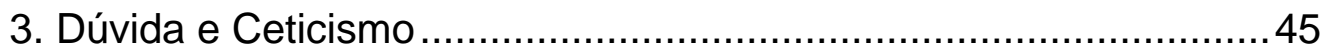

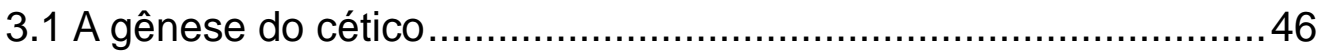

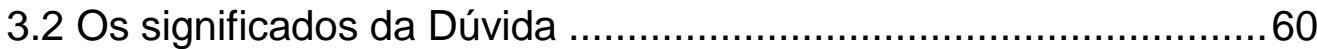

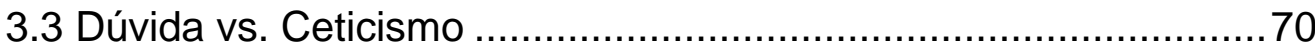

4.O Desaparecimento e a Redescoberta do Ceticismo .....................87

5. A apropriação da dúvida pelo pensamento filosófico .....................110

5.1 O uso filosófico da dúvida nos Academica de Cícero .................. 111

5.2 O pensamento escolástico....................................................126

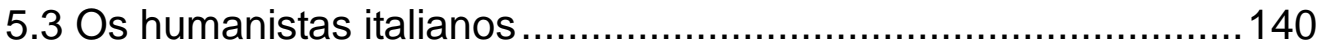

6. A introdução da dúvida no ceticismo ........................................151

6.1 As traduções latinas das fontes céticas ....................................152

6.2 A Reforma Protestante ......................................................156

6.3 Montaigne e a Apologia de Raymond Sebond ...........................164

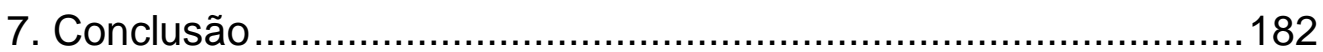

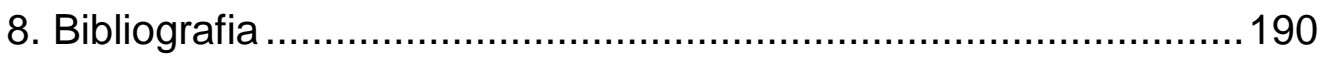




\section{Introdução}

A despeito do crescente número de trabalhos, congressos e livros dedicados à tradição cética desde a década de 1980, ainda é frequente considerar-se o ceticismo uma "filosofia da dúvida". $\mathrm{Na}$ verdade, a suposta sinonímia entre dúvida e ceticismo atualmente é dominante. Tanto no meio filosófico, quanto no uso da linguagem comum "dúvida" e "ceticismo" são tratados como equivalentes ou intercambiáveis. No entanto, não há uma relação direta entre ceticismo e o conceito de dúvida. Em suas origens gregas, o cético não é quem duvida ou que "coloca tudo em dúvida". Na obra de Sexto Empírico (séc. II a.C.), a principal fonte textual sobre o ceticismo antigo, estão ausentes os termos gregos correspondentes ao conceito de dúvida (tais como distázo, endoiázo, diakrino, dentre outros). A dúvida não é utilizada por Sexto em sua descrição do ceticismo e seu procedimento investigativo. Para Sexto, o cético não é alguém que está em dúvida, ou que 'lança dúvidas' sobre a filosofia dogmática. Estas formulações não ocorrem nenhuma vez em suas obras. Benson Mates (1996, p.30) frisa este ponto:

É um fato interessante, com importantes consequências filosóficas, que em sua narrativa sobre o pirronismo Sexto nunca fale sobre a dúvida. Não faltam verbos na língua grega para expressar tal condição (p.ex., endoiazó, distazó), mas ele nunca faz uso de nenhum deles. Em vez disso, para a atitude característica do pirrônico, Sexto utiliza os verbos aporó e améchanó, que significam "estar sem recursos" (to be at a loss). ${ }^{1}$

Sexto não fala de dúvida nem descreve o cético através de termos similares ou correspondentes à dúvida que lhe eram disponíveis. Distázo é um termo grego

1 Nas palavras de Paganini (2008), "Sexto nunca fala da dúvida no sentido próprio e moderno da palavra em sua exposição do ceticismo, ainda que a língua grega não careça de verbos para expressar este estado de espírito (tais como os verbos endoiázein, distázein: Platão faz uso desta última palavra sobretudo no Teeteto, nas Leis e no Sofista)". 
comum, equivalente à dúvida, porém, Sexto não o utiliza para descrever o cético. Distazó deriva de dis, assim como dubitare - o vocábulo latino que está na origem do termo nas línguas latinas modernas- deriva, através de dubius, de duo. O radical de ambas as palavras é o numeral dois, e possuem o mesmo sentido: estar entre duas alternativas, hesitar entre elas. A dúvida designa um estado em que pode se encontrar o pensamento; a situação frequente de ver-se entre duas ou mais alternativas, e hesitar entre elas - no entanto, não é este o estado em que se encontra o cético na descrição de Sexto. Embora a ausência dos termos gregos correspondentes à dúvida seja um fato textual na obra de Sexto, até mesmo especialistas consideram que o cético é aquele que duvida: ser cético e duvidar são frequentemente tratados como "atitudes" equivalentes. Este equívoco é acusado por Katya Vogt:

Até mesmo especialistas sobre a Antiguidade às vezes falam como se a dúvida fosse obviamente um ingrediente do ceticismo. Observe o título de uma coleção de artigos da década de 1980: Dúvida e Dogmatismo: Estudos sobre a Filosofia Helenística, eds. Schofield, Burnyeat, e Barnes [...] às vezes usa o termo "dúvida" ao discutir sobre o ceticismo pirrônico, bem como "certeza", o oposto da dúvida na filosofia moderna, igualmente ausente da discussão antiga como termo técnico ${ }^{2}$.

Muitos exemplos poderiam ser fornecidos para este equívoco frequente, porém basta citar alguns estudiosos de prestígio do ceticismo e da filosofia antiga. Segundo Couissin (1983), "A epoche pirrônica é a atitude mental de não conferir nem negar o assentimento: é dúvida”. Couissin toma a epoche pirrônica e a "atitude mental" cética como equivalentes à noção de dúvida. Julia Annas e Jonathan Barnes entendem o ceticismo como a expressão de uma atitude dubitativa: "Os céticos são aqueles que duvidam: eles não creem nem descreem, não afirmam nem negam" (Annas \& Barnes, 1985). No entanto, dúvida e ceticismo não são equivalentes: a atitude de não crer, nem descrer é propriamente cética, não uma atitude dubitativa.

2 Katja Maria Vogt. "Why Ancient Skeptics Don't Doubt the Existence of the External World: Augustine and the Beginnings of Modern Skepticism". In: Roman Reflections: Essays in Latin Philosophy, eds. Katharina Volk and Gareth Williams. No prelo. 
Desta maneira, inclusive entre especialistas em filosofia antigade não há clareza suficiente de que a dúvida está ausente do ceticismo grego, e de que não há uma conexão direta ou intrínseca entre ambos. E deve-se frisar que até mesmo especialistas que chamam atenção para o fato de que a dúvida não se encontra no ceticismo descrito por Sexto Empírico, ainda assim mantêm que haveria alguma relação fundamental estre ambos. Deve-se frisar, portanto, que em nenhum momento da sua narrativa sobre o ceticismo, Sexto oferece elementos que tornem possível aproximar o que descreve como próprio ao cético da noção comum de dúvida. Não só não há nenhum termo grego equivalente à noção de dúvida, mas também a dúvida enquanto atitude está ausente na sua descrição do ceticismo: além das palavras estarem ausentes, não se pode encontrar uma "atitude dubitativa" no cético pirrônico. Felizmente, Sexto inclui em sua descrição a atitude própria do cético, a qual se pode ver ser de nenhum modo equivalente a uma atitude dubitativa.

Portanto, no capítulo três temos em vista trazer à tona um sentido de ceticismo em que não é equivalente e não se confunde com a crença, com a descrença ou com a dúvida. Em vez de semelhante ou equivalente a outros fenômenos mentais, o ceticismo assinala um fenômeno particular da consciência, um estado mental específico, que consiste em não afirmar e não negar, mas em estar "em suspenso" em relação a ambas alternativas. Este estado mental não se confunde com uma atitude dubitativa, com a desconfiança ou a incredulidade; e não é oscilação, hesitação ou indecisão entre alternativas.

De modo a ilustrar a diferença entre o ceticismo pirrônico e a noção de dúvida, o filósofo norueguês Arne Naess (1968, pp. 69-70) refere-se aos casos clínicos de "dúvida geral e profunda" discutidos por Karl Jaspers em seu compendio de Psicopatologia Geral. Naess compara os sintomas de um paciente acometido pela "síndrome da dúvida" (Zweifelsuche; folie du doute) com um cético pirrônico: o que teriam em comum? Uma vez estabelecida a sinonímia entre ceticismo e dúvida, o que seria capaz de evitar que casos extremos como psicopatologias possam ser descritas como os sintomas de um cético? 
Atualmente, a neurociência busca mapear a atividade cerebral, utilizando técnicas como a imagem por ressonância magnética funcional (fMRI), e recentemente busca realizar experimentos para descortinar uma "neurologia da crença". Um dos principais estudos, realizados por Harris et al. (2008), apresenta resultados interessantes no que diz respeito às diferentes áreas cerebrais ativadas no tocante à "crença, descrença e incerteza". Cabe perguntar, no entanto, o que exatamente seria a incerteza, e de que modo se diferencia de um estado de dúvida ou de incredulidade: o estudo de Harris reconhece que não aborda as possíveis diferenças existentes entre "crença", "descrença" e "incerteza" ${ }^{3}$. Outros estudos, no entanto, não tomam esta precaução. Na pesquisa de Asp et al. (2012), por exemplo, simplesmente se equaciona a dúvida e a incredulidade ao ceticismo. Tomando ambos os termos como equivalentes, qual fenômeno mental se estaria exatamente buscando ao nível da atividade cerebral? Claramente, a incredulidade. Mas por que utilizar o termo ceticismo como sinônimo de incredulidade?

Pode-se afirmar que a principal razão para a maioria dos especialistas em filosofia cética e antiga ${ }^{4}$ aceitarem a sinonímia entre o cético e a atitude de duvidar reside em que este entendimento está profundamente enraizado em nosso modo de pensar, e amplamente disseminado em nossa cultura. Luiz Bicca (2014, p. 5) aponta para este fato (que atinge até mesmo os especialistas):

No que diz respeito ao ceticismo, todo mundo acha que sabe o que é, nestes nossos tempos, qualquer um pensa dele ter uma noção ou fazer-se uma idéia, mesmo que vaga, -- a definição mais comum do cético sendo aquela que diz tratar-se de alguém que duvida de tudo.

3 Alguns exemplos das perguntas desenvolvidas neste estudo para gerar a incerteza são: "Jesus spoke 2,467 words in the New Testament", "Akrasia means 'weakness of will", e "The Dow Jones Industrial Average rose 1.2\% last tuesday" (Harris et. al., 2008, p. 142 ).

4 Dentre os autores que fazem a distinção entre dúvida e ceticismo, pode-se destacar L. Corti, B. Mates, A. Naess, G. Paganini, K. Vogt e M. Williams. 
Veremos adiante a extensão que esta sinonímia atinge, analisando os usos do termo ceticismo pelo senso comum atualmente em vigor. No uso corrente da linguagem comum pode-se encontrar uma constelação de significados de "ceticismo". O emprego mais frequente e familiar do termo "cético" diz respeito a ser incrédulo, no sentido de ter "uma opinião desfavorável quanto ao sucesso de uma empresa ou empreitada", ou de demonstrar "incredulidade ou falta de confiança a respeito da veracidade de um fato" 5 . De acordo com outras definições, o cético é "uma pessoa que mantém uma atitude de dúvida a respeito dos valores, planos e caráter dos outros" "6; e pode até aproximar-se do sarcasmo, da falsidade ou inautenticidade, enquanto o ceticismo seria própiro de quem deseja aparentar ser um "espírito incrédulo", e desconfiar de todas as opiniões e valores preconcebidos. Esta incredulidade pode dizer respeito particularmente a quem coloca em dúvida o valor das máximas morais religiosas, ou inclusive duvida das crenças e dogmas religiosos, sendo neste caso o cético um sinônimo para ateu ou irreligioso ${ }^{7}$.

Desse modo, nota-se que a atitude cética costuma ser vista pelo senso comum como uma atitude carregada de preconceitos, já que o cético sempre exercerá a sua incredulidade, independentemente do tópico em questão: o cético seria alguém sempre incrédulo e desconfiado, inclusive em situações que não possua razão ou motivos para assim proceder. Pode-se destacar ainda a conexão entre o ceticismo e a atitude científica. Nesta variante, o ceticismo consistiria na recusa de admitir qualquer coisa sem prévio exame crítico, sendo fundamental para a adoção de uma atitude científica. O cético seria aquele que pratica o exame crítico, a dúvida científica, a qual seria oposta à credulidade. Neste sentido, o ceticismo e a atitude científica têm o seu ponto de encontro na dúvida, tomada

5 Definições adaptadas dos dicionários LALANDE (1999), verbete "Céptico" (crítica), e LE PETIT ROBERT (2008), verbete "Scepticisme".

6 RANDOM HOUSE WEBSTER'S COLLEGE DICTIONARY (1990), verbete “skeptic”.

7 Ver Don Cameron Allen (1964). 
como a prática de não se admitir nada sem prévio exame crítico ${ }^{8}$. É interessante notar o esforço de Carl Sagan para incentivar o pensamento crítico em seu artigo The Burden of Skepticism (1987), em que ilustra a necessidade do "fardo do ceticismo" através da situação de negociar com um vendedor de carros usados:

Você sabe que é preciso algum grau de ceticismo, e entende por quê. É aborrecedor que você talvez tenha que discordar do vendedor de carros usados, ou colocar-lhe perguntas que ele fique relutante em responder. Há ao menos um pequeno grau de confronto na compra de um carro usado e nninguém sustenta que isto seja algo especialmente agradável. Mas há uma boa razão para que ocorra - por que se você não exercitar um mínimo ceticismo, se tiver uma credulidade absolutamente desimpedida, há provavelmente um preço que precisará pagar mais tarde. Então você irá desejar que tivesse feito um pequeno investimento no ceticismo desde cedo.

Nesta conexão entre ceticismo e atitude científica, podem-se encontrar outras interpretações a respeito do aspecto positivo da dúvida, especialmente no que diz respeito à metodologia da pesquisa científica e seu uso enquanto ferramenta para desmascarar a pseudociência. Nota-se que este uso do termo ceticismo é bastante comum atualmente, sendo promovido por diversas instituições, tais como a CSICOP (Comitê para a Investigação Cética de Alegações Paranormais), fundada por Carl Sagan e Paul Kurtz, e a Fundação Educacional James Randi. E, por fim, nota-se que o ceticismo é utilizado para expressar um ponto de vista ou dúvida política, como no caso dos Eurosceptics.

É digno de nota que em todos estes “domínios", desde o entendimento mais simples e disseminado, até as interpretações filosóficas de comentadores autorizados, o modo de se compreender o ceticismo é decisivamente marcado pela dúvida. Deste modo, no entendimento do senso comum, o ceticismo aponta para uma atitude mental de descrença e incredulidade, e enquanto doutrina assinala uma posição filosófica que expressa desconfiança no tocante à possibilidade de um conhecimento dotado de certeza (sentido epistêmico). Portanto, a partir do

8 Diderot dá a sua voz a esta concepção quando afirma que "o ceticismo é o primeiro passo a caminho da verdade". 
uso da linguagem comum, que engloba o entendimento geral do senso comum, da religião e da ciência, a visão geral que se tem do ceticismo diz respeito a uma atitude ou doutrina em cuja essência está a incredulidade, sendo a sua prática fundamental o "exercício da dúvida". O cético é quem pratica a dúvida. Deste modo, podem-se apresentar resumidamente ao menos seis diferentes significados atuais para o ceticismo, de acordo com os quais o "cético" seria aquele que:

1) coloca tudo em dúvida; é descrente (sentido geral);

2) é incrédulo, desconfiado (sentido psicológico);

3) duvida da possibilidade de um conhecimento certo e indubitável, seja de modo irrestrito, seja de modo limitado a determinado domínio (sentido epistêmico);

4) duvida da moral instituída e dos valores recebidos; libertino (sentido moral);

5) duvida da crença e dos dogmas religiosos (sentido religioso);

6) tem a dúvida como princípio, recusando admitir qualquer coisa sem prévio exame crítico (sentido científico).

Pode-se notar que em todas estas variadas concepções de ceticismo em uso corrente na linguagem comum, entende-se o ceticismo em conexão à noção de dúvida. É aparente, portanto, a forte correlação hoje existente entre ceticismo e dúvida: o cético é entendido como quem duvida; e os diferentes usos correntes do termo "ceticismo" correspondem aos diversos sentidos ou dimensões em que se pensa a dúvida (psicológico, moral, epistêmico, religioso, e científico). Portanto, os diferentes modos de se avaliar o ceticismo dependem de como se entende a "prática da dúvida" em meio à sua polissemia. Mais frequentemente, o ceticismo possui uma conotação pejorativa. O cético seria quem duvida de tudo e "duvida 
por duvidar", sem motivos, razões, ou propósito ${ }^{9}$. E, na mesma medida, mais frequentemente entende-se a dúvida como sinônimo de desconfiança, descrença e incredulidade. Entretanto, pode-se enxergar o ceticismo de um modo positivo. $\mathrm{Na}$ condição de qualidade do pensamento crítico, que é exigida pela atitude científica, o "exercício da dúvida" é valorizado, pois representa a atitude crítica de não se aceitar nada sem prévio exame. Neste caso, tanto a noção de dúvida quanto o ceticismo, enquanto sinônimo da "dúvida científica", possuem conotações positivas em conexão ao "questionamento crítico". Diante desta pluralidade de modos de se entender tanto o ceticismo quanto a noção de dúvida, o que significaria dizer que o cético é alguém que duvida? O que esta sinonímia seria capaz de revelar sobre o ceticismo? Após uma breve caracterização da tradição cética antiga e do ceticismo pirrônico no segundo capítulo, buscaremos responder a estas perguntas no terceiro capítulo. Gostaríamos de agora propor a seguinte questão relativa à história das ideias: se não há dúvida no ceticismo grego, como teria ocorrido o processo de identificação entre ambos e a produção da sua sinonímia, que é atualmente um lugar comum?

"Ceticismo" é um termo filosófico cujo surgimento está associado aos pensadores da escola pirrônica (fundada ca. I séc. a.C.), os primeiros a serem denominados céticos. Os pirrônicos ficaram conhecidos como os skeptikoi (do verbo skopein: investigar, olhar atentamente), pois em suas investigações não encontram nenhum resultado: continuam buscando. Deste modo, é apenas tardiamente, com os skeptikoí da escola pirrônica que se pode remontar à origem do termo cético na filosofia antiga, que surge para designar uma escola de pensamento filosófico.

O ceticismo praticamente desaparece durante todo o período medieval (principalmente no Ocidente), vindo a ser retomado apenas no contexto do humanismo florentino, na primeira metade do século XV. Com a progressiva disseminação dos textos céticos antigos, dá-se início às tentativas de reconstrução

9 Descartes, Discurso do Método, III. Para Descartes, a "dúvida cética" seria vã e sem propósito, e nota-se que esta interpretação do ceticismo encontra-se já em Montaigne. 
do seu significado, multiplicando-se as interpretações e usos do ceticismo. É a partir desta época que o ceticismo incorpora-se à linguagem comum, e durante o século XVI o vocábulo surge nas línguas modernas. Pode-se afirmar que desde então ceticismo e dúvida estão entrelaçados, o que está profundamente enraizado tanto na visão filosófica, quanto na visão comum de ceticismo (ver quarto capítulo).

A dúvida é um termo da linguagem comum, que descreve uma atitude mental, ou um estado da consciência. Originalmente, possui um uso cotidiano ou comum, não filosófico. Como termo da linguagem comum, a dúvida foi apropriada pela filosofia, vindo a tornar-se um termo semitécnico significativo para o pensamento filosófico especialmente na modernidade, desempenhando notoriamente um papel central na filosofia cartesiana. Na filosofia antiga não se pode notar a dúvida ocupar nenhuma posição de destaque ou desempenhar o papel de uma questão relevante, não sendo na Antiguidade grega que ocorre a passagem da dúvida de um termo comum da linguagem cotidiana, que expressa um estado mental, conhecido por todos nós, ao seu uso conceitual na filosofia, através do qual se elaboram questões e teorias filosóficas.

Como veremos no quinto capítulo, a dúvida começa a receber um lugar de destaque para o pensamento filosófico pelo menos desde Cícero. O pensador romano faz uso da dúvida para fazer a distinção entre o dogmatismo e a sua própria concepção de filosofia, que aos seus olhos é a filosofia acadêmica. Em $D e$ Trinitate X, 10, Santo Agostinho notoriamente desenvolve um pensamento filosófico fazendo uso do conceito de dúvida, mostrando que há algo de indubitável como condição de possibilidade para que possa colocar qualquer coisa em dúvida ${ }^{11}$. Embora Cícero e Agostinho já façam um uso filosófico da noção de dúvida, é a partir do século XII, no contexto do pensamento escolástico, que os conceitos de dúvida e certeza passam a receber uma importância filosófica cada vez maior. E a importância destas noções verifica-se igualmente no pensamento humanista. Portanto, a dúvida é um termo próprio da linguagem comum que é

\footnotetext{
${ }^{11}$ Fato para o qual muitos intérpretes chamam a atenção. Ver, por ex., Wittgenstein, Da Certeza, §§ 341-343.
} 
apropriado pelo pensamento filosófico, e, pela via inversa, o ceticismo é um termo que tem origem na filosofia helenística e, com os humanistas italianos passa a ser incorporado à linguagem comum. No início do período moderno, a dúvida e a certeza já são termos centrais para o pensamento da época.

Dentre os intérpretes que assinalam o fato de que o conceito de dúvida está ausente do ceticismo pirrônico, especialmente L. Corti e M. Williams buscam distinguir especificamente entre o Pirronismo e a dúvida cartesiana, mostrando, cada um ao seu modo, de quais maneiras a dúvida e o ceticismo são conceitualmente diferentes e mesmo contraditórios. A noção de dúvida é fundamental para o ceticismo moderno, e esta importância recebe uma medida sem paralelos a partir de Descartes. Embora Descartes seja a referência paradigmática para a consolidação do "ceticismo moderno", especialmente quando se tem em mente o "método da dúvida" e o "problema da existência do mundo externo", não iremos conferir atenção especial ao legado de Descartes para a transformação do ceticismo, e não iremos cotejar o ceticismo e a dúvida através da referência ao pensamento de Descartes. Como escreve Paganini:

Temos o costume de pensar que a dúvida e o ceticismo são inteiramente coextensivos, e que, portanto não poderia haver um cético que não fosse ao mesmo tempo alguém que duvida: a dúvida tornou-se para nós um sinônimo perfeito de ceticismo. Embora isto seja verdadeiro para os modernos, e a fortiori para aqueles que vêm após Descartes, isto não é nem igual ou forçosamente verdadeiro para os antigos. (Paganini, 2008, p.56)

Como sugere Paganini, pode-se considerar ser Descartes o ponto de chegada do processo de identificação entre dúvida e ceticismo. Após Descartes, esta sinonímia torna-se completa, especialmente no que diz respeito ao "cético" tornarse uma posição anônima, um interlocutor fictício do debate epistemológico moderno e contemporâneo. Portanto, em Descartes, não apenas dúvida e ceticismo se confundem e se identificam, mas esta sinonímia é levada para o palco da epistemologia moderna, cujo quadro conceitual é amplamente influente e de muitas formas ainda hoje em vigor. Como assinala Floridi, após Descartes todos os elementos do modo como hoje pensamos o ceticismo já estão presentes: 
O dualismo que se requer para produzir uma dúvida séria, a mudança epistemológica trazida pelas novas descobertas científicas, tais como as de Copérnico e Galileu, as novas explorações geográficas e astronômicas, a crise do paradigma aristotélico-escolástico na epistemologia, o foco no sujeito individual como o elemento sobre o qual uma nova teoria do conhecimento poderia se desenvolver, a Reforma, a Contra-Reforma e o fim do monopólio católico em questões de fé religiosa e educação intelectual, e a redescoberta de filosofias do passado com os seus desacordos irreconciliáveis estavam dentre os fatores que abriram uma nova era na história do ceticismo, uma era na qual ainda nos encontramos. (2002, p.51)

Tendemos a ler a questão da dúvida a partir do que Descartes fez, e a avaliar a significância da filosofia cética antiga a partir do nosso próprio ponto de vista, e de acordo com o contexto das nossas próprias questões. Como afirma Naess (1969, p. 33), "Talvez tenham sido as preocupações filosóficas de agora e do passado que fizeram o maior disserviço ao ceticismo". Mas, se com Descartes ocorre a consolidação da sinonímia entre dúvida e ceticismo, de que modo teria sido a dúvida primeiramente introduzida no ceticismo? No sexto capítulo, nossa tarefa historica será reunir alguns exemplos ilustrativos para abordar esta questão. Desta maneira, a nossa abordagem centra-se, sobretudo no que se costuma chamar de "ceticismo renascentista"; o período que vai do início do século XV ao final do século XVI. Este pode ser considerado o período fundamental para a análise da introdução da dúvida no ceticismo, o qual corresponde à redescoberta do ceticismo na década de 1430 e estende-se até à publicação da Apologia de Raymond Sebond (1580) de Montaigne, em que uma apresentação compreensiva do ceticismo é pautada na noção de dúvida. Portanto, nota-se que esta tese não abrange Descartes e o século XVII. Sendo nosso tema a dúvida e o ceticismo, por que não falamos de Descartes? Optamos por tratar de um contexto da dúvida 'précartesiana' por dois motivos principais.

Em primeiro lugar, é a partir da sua redescoberta no início do século XV que a dúvida é introduzida no ceticismo. Deste modo, a sinonímia entre dúvida e ceticismo tem início desde a sua redescoberta no contexto do humanismo florentino, cerca de dois séculos antes da publicação das Meditações. Entre os 
comentadores especializados que reconhecem não haver dúvida no ceticismo grego, tais como Paganini, Naya e Vogt, este parece ser um ponto consensual: a introdução da dúvida no ceticismo ocorre a partir da sua redescoberta no Renascimento. Portanto, é com a redescoberta do ceticismo no contexto florentino, a partir do início do século XV, que se deve investigar o fenômeno de introdução do conceito de dúvida no ceticismo e o seu processo de transformação através deste conceito.

Em segundo lugar, como a introdução da dúvida no ceticismo ocorre muito tempo antes de Descartes, o conceito de dúvida não dizia respeito ainda a uma “dúvida metafísica”. Pode-se considerar a dúvida cartesiana indissociável da originalidade do projeto de encontrar um novo fundamento para o conhecimento o que, por sua vez pode ser entendido como a inaurugação de um novo modelo para o conhecimento ${ }^{13}$. Como se costuma afirmar, a grande inovação do pensamento de Descartes se dá no domínio da metafísica; centrando-se na subjetividade, apresenta uma nova fundação metafísica para o conhecimento humano, a qual traz consigo pressupostos epistemológicos radicalmente novos. Portanto, a dúvida cartesiana faz parte de um projeto metafísico de fundação do conhecimento certo e inabalável, sendo por seu intermédio que um novo fundamento e um novo modelo para o conhecimento é sedimentado. Descartes trata nas Meditações, em suas palavras, da "dúvida metafísica”, em oposição à dúvida que poderia ser considerada "natural"14. Cabe frisar que, com o nosso enfoque, não tivemos a pretensão de dimunuir a originalidade e a radicalidade do pensamento cartesiano nem o seu papel na formação do ceticismo moderno e da ideia de "dúvida cética". Apenas buscamos delinear algumas das vias pelas quais a noção de dúvida é apropriada pelo pensamento filosófico, as quais influenciam diretamente a introdução da dúvida no ceticismo já a partir da sua redescoberta no início do século XV.

\footnotetext{
${ }^{13}$ Ver, Langer, 1929.

14 Ver Williams, Unnatural Doubts (1996).
} 


\section{2}

\section{A tradição cética antiga}

Há duas tradições do ceticismo grego: o ceticismo acadêmico e pirrônico. Em 2.1, seguimos em linhas gerais a exposição do ceticismo efetuada por Sexto Empírico (especialmente em Hipotiposes Pirrrônicas, livro I), cuja obra é a principal fonte do ceticismo pirrônico e da tradição cética antiga em geral. Em sua exposição, nota-se como o termo "dúvida" não se faz presente, e tampouco a noção de dúvida é necessária para seguir a sua exposição do ceticismo e compreendê-lo.

A controvérsia a respeito das diferenças entre acadêmicos e pirrônicos é uma questão polêmica, que se encontra desde a Antiguidade. Como veremos, não é claro se haveria uma diferença essencial entre elas, especialmente tendo-se em vista Arcesilau e Carnéades, os principais representantes da filosofia neoacadêmica. E nestes, assim como no ceticismo pirrônico, não há um uso técnico do termo dúvida, nem figura de modo relevante a noção de dúvida nos relatos sobre a sua prática filosófica. No entanto, em vez de aprofundarmo-nos nesta antiga polêmica, nosso interese concentra-se nas diferenças entre as suas respectivas tradições textuais: embora nem o termo, nem a noção de dúvida se façam presentes no ceticismo grego, e desta maneira não desempenhem nenhum papel relevante, por outro lado, como veremos (seção 5.1), o termo dúvida (dubitare) figura nos Academica de Cícero, a principal fonte disponível sobre a tradição acadêmica, sendo este termo inserido, dentre outros modos, precisamente em sua descrição das diferenças entre a filosofia acadêmica e a dogmática.

As duas principais fontes textuais da tradição cética antiga parecem desenvolver-se em contextos independentes entre si. Sexto Empírico em nenhum momento menciona Cícero, e este em nenhum momento refere-se a Enesidemo, 
Timon ou ao pirronismo. A tradição comum a que ambos Cícero e Sexto Empírico se referem termina com Fílon de Larissa. As fontes textuais hoje disponíveis do ceticismo antigo são de uma época já bem distante da tradição e das controvérsias por elas narradas. As fontes disponíveis são todas secundárias: seus autores descrevem uma tradição mais antiga e já remota. E não há, nem mesmo na Antiguidade, uma tradição cética única ou linear, e sim uma história de cinco séculos de rupturas, dissidências e discordâncias, até mesmo sobre o conceito de ceticismo. A este respeito Marcondes (A tradição cética, p. 1) escreve:

Ao examinarmos a tradição cética vemos, no entanto, que não há um ceticismo, mas várias concepções diferentes de ceticismo, e mesmo o que podemos considerar a "tradição cética" não se constituiu linearmente a partir de um momento inaugural ou da figura de um grande mestre fundador, mas se trata muito mais de uma tradição reconstruída.

Os supostos "fundadores" do ceticismo, Sócrates e Pirro, são figuras resgatadas da tradição retrospectivamente, que não fundaram nenhuma escola, nem deixaram escritos. Segundo Sexto Empírico, Enesidemo teria resgatado a figura de Pirro (c. 365-275 a.C.), contemporâneo mais velho de Alexandre, o Grande para denominar a sua escola, por considerar que a vida de Pirro apresentaria o melhor exemplo de uma vida cética ${ }^{15}$. A obra de Enesidemo está perdida, e pouco se sabe sobre a sua vida. Pirro não deixa escritos, nem funda uma escola. Tímon (c.325-), discípulo de Pirro, relata as respostas de seu mestre a três questões fundamentais:

1) Qual a natureza das coisas? Nem os sentidos nem a razão nos permitem conhecer as coisas tais como são e todas as tentativas resultam em fracasso. 2) Como devemos agir em relação à realidade que nos cerca? Exatamente porque não podemos conhecer a natureza das coisas, devemos evitar assumir posições acerca

15 Cf. Sexto Empírico, Hipotiposes Pirrônicas, I, ii 7, e Diógenes Laércio, A Vida dos Filósofos Ilustres, IX. 
disto. 3) Quais as consequências dessa nossa atitude? O distanciamento que mantemos leva-nos à tranquilidade. ${ }^{16}$

Pirro teria acusado a inapreensibilidade das coisas, apontando para que não se pode conhecer as coisas tais como são, devendo-se portanto evitar assumir posições dogmáticas acerca disto; e este distanciamento seria o que nos levaria à tranquilidade. Portanto, pode-se notar em Pirro fundamentalmente uma atitude e um modo de vida ${ }^{17}$, os quais teriam sido posteriormente resgatados e introduzidos ao ceticismo pirrônico, especialmente, o entendimento de que com uma postura não dogmática é possível viver bem e atingir a tranquilidade.

Se Pirro parece ser o melhor exemplo de quem teria não apenas pensado, mas vivido o ceticismo, por outro lado não funda uma escola propriamente dita, nada escreve, e se houve uma continuidade do seu pensamento entre os seus seguidores após a sua morte, esta parece ter sido de curta duração e escopo (Zeller, 2010, p. 520). Portanto, a origem da filosofia cética estabelecida enquanto escola de pensamento parece ocorrer no interior da Academia de Platão, durante a liderança de Arcesilau de Pitane (c. 315-240 a.C.), o quarto escolarca na sucessão da Academia após a morte de Platão. De acordo com outra tradição, o ceticismo teria se iniciado com Arcesilau diretamente a partir de uma inspiração socrática. Em um texto anônimo do séc. VI, intitulado Introdução à Filosofia de Platão ${ }^{18}$, uma busca semelhante ocorre em relação ao pensamento platônico:

Em sua discussão acerca das coisas, dizem, ele [Platão] usa certos advérbios indicando ambivalência e dúvida, por exemplo, "provavelmente" e "talvez", e isto é uma característica não de quem sabe, mas de alguém que não consegue apreender nenhum conhecimento preciso (...). Argumentam, em segundo lugar, que na medida em que ele procura estabelecer visões contrárias acerca das mesmas coisas, claramente defende a sua inapreensibilidade - p.ex. procura estabelecer posições contrárias ao discutir a amizade no Lisis, a temperança no Carmides, a piedade no

16 apud Marcondes (2000).

17 Sobre a atitude de Pirro, ver Bicca, 2014.

18 Citado em Marcondes (2000). 
Eutifron (...). Em terceiro lugar, dizem que ele considera que não há conhecimento, como fica claro na medida em que refuta todas as definições de conhecimento no Teeteto. Seu quarto argumento é que se Platão considera que o conhecimento é de dois tipos, um proveniente dos sentidos, outro do pensamento, e que ambos falham, então é claro que ele defende a inapreensibilidade (...). O quinto argumento é que ele próprio diz em seus diálogos "Eu não sei nada e não ensino nada, tudo que faço é levantar problemas".

Arcesilau é considerado o inaugurador da assim chamada 'fase cética' da Academia de Platão, conhecida como a Nova Academia, embora ao fazê-lo pudesse estar apenas seguindo a própria tradição acadêmica de Sócrates e Platão. Portanto, Sócrates, que teria sido a inspiração para a prática cética de Arcesilau não deixa escritos, e tampouco Pirro, a figura inspiradora da nova escola cética inaugurada por Enesidemo. Sócrates e Pirro seriam, portanto, os "fundadores" da tradição cética antiga, mas que, no entanto, não as fundaram de fato, sendo figuras resgatadas da tradição para exercer este papel.

Em Sobre os Fins, 2.2, Cícero escreve: "Arcesilau retoma a prática socrática" e, nos Academica, argumenta, contra Antíoco de Ascalon, que a Nova Academia seria a legítima sucessora da tradição socrática e platônica. Sustentar que Arcesilau retoma a prática socrática significa afirmar a filiação de Arcesilau à tradição acadêmica desde Sócrates: o pensamento neoacadêmico estaria em consonância com o seu "mestre fundador". Cícero argumenta que haveria apenas uma Academia, pois a assim chamada Nova Academia, na verdade, não se distinguiria da velha Academia, mas daria prosseguimento aos ensinamentos de Platão. Deste modo, haveria apenas uma Academia, desde Sócrates e Platão, a Arcesilau e Carnéades, até a sua própria época (Acad., I, 46). Diógenes Laércio e Sexto Empírico (HP I, 232) fornecem relatos diferentes. Neles se encontra a diferenciação entre a Velha, a Média, a Nova e até a Quarta e Quinta Academias. (D.L., 4.28).

O pensamento "cético" de Arcesilau floresce sobretudo através da sua controvérsia contra os estoicos. Estes mantinham que o homem sábio confere o seu assentimento tão somente a uma apresentação ou impressão cognitiva 
(phantasia kataleptike), e que ele nunca opina. A noção de "homem sábio" desempenha um papel especial nas filosofias do Helenismo, em particular a partir do desenvolvimento que recebe com a filosofia da Stoa. O homem sábio é dotado de todos os atributos desejáveis, sendo o modelo de uma conduta prática virtuosa, livre do erro e das falsas opiniões sustentadas pelo homem comum. Uma impressão cognitiva seria aquela que traz consigo a evidência de que corresponde ao seu objeto, não podendo derivar de algo não existente, sendo precisa e clara de que realmente é o caso aquilo que apresenta. Deste modo, a impressão cognitiva é o critério de verdade da teoria do conhecimento estoica: possuiu necessariamente um objeto real como a sua causa, e o apresenta com completa precisão e clareza. Ainda, de acordo com Zenão (334-262 a. C.), como o homem sábio nunca opina, na ausência de uma impressão cognitiva suspenderia o juízo (epoche). Diante disto, de acordo com Sexto Empírico (Contra os Professores, VII, 151), Arcesilau afirma que "Se tudo for incognitivo, segue-se, de acordo inclusive com os estoicos, que o homem sábio suspende o juízo".

Enquanto para os estoicos a epoche assinalava uma limitação do homem sábio, com Arcesilau torna-se índice de sabedoria, originando-se uma noção "cética" de epoche: sendo tudo inapreensível, é sábio suspender-se: "Arcesilau é o primeiro a expor, ou mesmo a formular a tese de que o homem pode abster-se de opinar e que o homem sábio não apenas pode, como deve fazê-lo”. (Acad. II, 7677). Deste modo, Arcesilau é considerado o primeiro a defender a suspensão a respeito de tudo, e, por conta disso, os acadêmicos viriam a ser conhecidos como os ephetikoi, "aqueles que suspendem o juízo sobre tudo" ${ }^{19}$, sendo caracterizados (de acordo com esta suposta citação de Crisipo) pela epoche generalizada. Neste momento, não é ainda utilizado o termo skepsis (exame, investigação), ou skopein (olhar atentamente, examinar), para descrever a prática de Arcesilau e os Acadêmicos, de modo que haveria um anacronismo em se falar de "ceticismo acadêmico", pois não havia ainda o termo "cético" (nem o substantivo “ceticismo"). O termo "cético" é utilizado para designar os discípulos da nova

19 Citação de Crisipo, Sobre a auto-contradição estoica, em Plutarco, Contra Colotes (1120c), apud Long \& Sedley, 1987, p. 440. 
escola fundada por Enesidemo, de modo que os primeiros usos deste termo datam de meados do século I a. C. (cf. Long \& Sedley, 1987). O uso anacrônico do termo cético para designar o pensamento da Academia ocorre desde a Antiguidade, encontrando-se presente já no relato de Numênio, em que é retrojetado a Arcesilau por pirrônicos de um período posterior:

[...] Arcesilau manteve-se fiel a Pirro, exceto pelo nome, pela negação de todas as coisas. De qualquer forma, Mnaseas, Philomemus e Timon, os céticos, o chamam de Cético, como eram eles próprios, já que ele também negava o verdadeiro, o falso, e o convincente ${ }^{20}$.

Atentar para o surgimento tardio do termo ceticismo em conexão com a escola pirrônica é relevante especialmente quando se tem em mente que Cícero aparentemente não conhece o pirronismo. Não menciona Pirro, Timon ou Enesidemo nos Academica, e os termos "cético" e "ceticismo" estão ausentes em toda sua obra. Logo, a filosofia acadêmica exposta e esposada por Cícero jamais é referida em sua obra como ceticismo.

Para defender-se em suas controvérsias da contra-argumentação dos estoicos, Arcesilau precisa defender a viabilidade da epoche generalizada, especialmente frente aos argumentos da apraxia e da autorrefutação. Ao minar a possibilidade da epoche cética, os estoicos enfraqueceriam as críticas à sua própria doutrina, pois as críticas céticas não se sustentariam a si mesmas. Em vista disso, Arcesilau sugere como critério para a conduta da vida o razoável (eulogon), através do qual seria possível suspender o assentimento sobre todas as coisas, e ainda assim ser possível agir de acordo com a suspensão sobre tudo. Deste modo, com este argumento, Arcesilau sugere que é possível agir e buscar a felicidade no mundo de modo razoável, mesmo sem se estar na posse de um conhecimento “científico". Em que medida Arcesilau pensa a noção de "razoável” tão somente como um argumento dialético, de modo a responder ao ataque estoico nos termos

20 Numênio apud Eusébio, Preparatio Evangelica, 14.6 4-6 Citado em Long \& Sedley,1987, p. 440 
da própria doutrina estoica, ou como um elemento doutrinário, é uma questão amplamente debatida, inclusive já na Antiguidade, questão que viria a se intensificar a respeito de Carnéades, o mais ilustre representante do ceticismo da Academia após Arcesilau, que se torna escolarca cerca de 50 anos após a sua morte.

Carnéades (219-129 a.C.) dá sequência à generalização da epoche iniciada por Arcesilau, ampliando o seu escopo para além do pensamento estoico, mas à filosofia em geral, embora a sua crítica ainda seja voltada em especial para o estoicismo, em sua época para o escolarca Crisipo (281-208 a. C.). Carnéades propõe o argumento do píthanon (convincente; plausível) como o critério para a conduta de ação. Embora haja casos em que não se pode distinguir impressões verdadeiras que são convincentemente verdadeiras, de impressões convincentemente verdadeiras, mas falsas, isto não seria o suficiente para descartar as impressões convincentes como critério de ação, pois, na maior parte das vezes, as impressões convincentemente verdadeiras são, de fato, verdadeiras. Deste modo, seria possível manter a epoche e ao mesmo tempo conferir o assentimento a impressões convincentes, de modo a guiar a vida prática, sem sustentar posições teóricas acerca da natureza real das coisas ou julgar que o conhecimento a este respeito deva ser infalível.

Os argumentos dialéticos de Arcesilau e Carnéades costumam ser entendidos como expressões de "falibilismo" - ao se admitir que não se está na posse da verdade, ainda é possível conceber critérios "sucedâneos da verdade" que permitiriam guiar a ação. Embora estes sejam reconhecidamente critérios falíveis, poderiam ser utilizados satisfatoriamente como guias para a conduta prática; na falta da verdade ou da melhor razão, o que se aproxima da verdade e se mostra plausível pode ser considerado o suficiente para se agir moralmente e buscar o bem viver e a felicidade.

Os critérios para a conduta da vida prática oferecidos por Arcesilau e Carnéades parecem ter em vista argumentar pela viabilidade da epoche, e pela possibilidade do bem viver mesmo sem se estar na posse de conhecimentos 
dogmáticos. No entanto, não consistem em uma doutrina, mas em argumentos dialéticos, concebidos e voltados especialmente contra os estoicos. Contudo, foram posteriormente utilizados como recursos para a elaboração de um sistema doutrinário, quando se configura um movimento dogmático surgido no interior da academia.

Costuma-se assinalar que a argumentação de Arcesilau se faz de modo inteiramente dialético, pois requer um oponente que afirme a sua tese, a qual será neutralizada com a argumentação pela tese contrária. Neste sentido, sendo o caso que os seus adversários sejam os estoicos, a significância da sua dialética argumentativa diria respeito à neutralização da filosofia estoica em sua oposição a ela. Portanto, a argumentação de Arcesilau não teria em vista sustentar a afirmação ou a negação de nenhuma tese ou princípio filosófico, senão mostrar como, a partir das próprias premissas em que se baseiam os argumentos estoicos, as suas teses não se sustentariam e, juntamente com a sua contra-argumentação, se cancelariam a si mesmas. Assim, pode-se descrever a epoche praticada por Arcesilau como a suspensão dos compromissos epistemológicos esposados pelos estoicos.

Carnéades teria ampliado a aplicabilidade da epoche ao argumentar em ambos os lados de uma questão por si mesma, não sendo necessária a referência a um adversário que coloca uma tese. Desta maneira, em seu próprio discurso é capaz de apresentar ambos os lados de qualquer questão de forma igualmente convincente, de modo a provocar a epoche em seus ouvintes, como faz em seus discursos sobre a justiça na ocasião da sua visita a Roma como embaixador de Atenas $^{21}$.

Nota-se que este aspecto universal da epoche é fundamental no ceticismo pirrônico descrito por Sexto Empírico. Ao pesar os argumentos de ambos os lados de um conflito, e encontrá-los em um estado de equipolência, o cético suspende o juízo sobre a matéria em questão. E, ao fazê-lo, suspende-se inteiramente do

21 Ver a este respeito Bicca (2009). 
conflito - tanto em relação a ambas as doutrinas em conflito, quanto ao conflito como um todo. Deste modo, o pirrônico suspende-se de todas as teses e argumentos com os quais estão envolvidas as doutrinas, bem como de todos os pressupostos e premissas sobre os quais estejam erguidas. Nesse sentido, o procedimento cético descrito por Sexto pode ser visto como o passo a passo de uma epoche universalizada, a qual Sexto entende como possível de ser aplicada a todo e qualquer conflito a respeito de algo não evidente. Deste modo, a prática cética consistiria em suspender-se de todo e qualquer compromisso epistemológico com o qual se possa deparar ao longo da sua investigação.

Embora seja um ponto controverso, pode-se considerar não haver indicações claras de que Arcesilau, e nem mesmo Carnéades teriam praticado a filosofia senão de um modo que se poderia considerar "cético"22, sendo por vezes até mesmo distinguir nitidamente entre o ceticismo pirrônico e o pensamento da Nova Academia, como o próprio Sexto Empírico assinala, ao afirmar que Arcesilau, "parece ter compartilhado as doutrinas de Pirro, de maneira que o seu modo de pensar seria quase idêntico ao nosso". Ainda segundo Sexto (HP I, 232):

[...] não se pode encontrá-lo fazendo asserções sobre a realidade ou a irrealidade de coisa nenhuma, nem prefere uma coisa a outra em matéria de probabilidade ou improbabilidade, mas suspende o juízo a respeito de tudo ${ }^{23}$

E segundo Cícero, assim como Arcesilau havia feito, também Carnéades pronunciava-se a favor e contra todos os assuntos, sem jamais expressar uma opinião decidida. (Cf. Cícero, Nat. Deo. I, 5, 11, Acad. II, 18, 60). Por outro lado, Sexto (HP I, 227) caracteriza o píthanon de Carnéades como um critério dogmático, através do qual se buscaria asseverar como as coisas seriam em sua essência.

22 Ver Long \& Sedley, 1987, p. 460 e Zeller, 2010, pp. 520; 521n; 552.

23 Ver Bolzani, 2011. 
[...] nós [pirrônicos] dizemos que são iguais no tocante a serem plausíveis ou implausíveis, no que diz respeito à sua essência, ao passo que eles afirmam que algumas impressões seriam plausíveis, e outras impressões seriam implausíveis.

Em HP I, 226, a afirmação da inapreensibilidade é tomada como o principal ponto de divergência entre acadêmicos e pirrônicos. Contudo, pode-se ler em Acad. I, 45 que "Arcesilau afirmava que nada pudesse ser conhecido, nem mesmo o resíduo de conhecimento que Sócrates havia mantido para si - a verdade desta própria afirmação". Nas palavras de Bolzani (2011, p. 15), "Se tudo é obscuro, a própria afirmação da obscuridade é, em si mesma, obscura”. Nada positivo permanece da prática dialética: como todas as coisas "estão escondidas em obscuridade" (in occulto), a "fórmula" utilizada por Arcesilau contra o dogmatismo seria autorreferente e, portanto, cancelaria a si mesma - da mesma maneira que Arcesilau entende que a filosofia estóica se cancelaria através dela mesma.

O nascimento do pirronismo está relacionado a acontecimentos ocorridos na Academia no século I a.C. Considera-se que, a partir da sistematização do pensamento de Carnéades elaborada por Clitômaco (ca.175-110 a.C.) companheiro e sucessor deste na liderança da Academia -, Fílon de Larissa (c. 160-79 a. C.), que por sua vez sucede de Clitômaco na Academia, teria dado início ao desenvolvimento do falibilismo neoacadêmico em uma doutrina positiva. Portanto, Filon de Larissa (fl. 100 a.C.) teria sido o responsável por instalar na Academia um movimento do retorno ao dogmatismo, a uma filosofia doutrinária, sendo durante a sua liderança que uma dissidência interna irrompe na escola.

Antíoco de Ascalon (fl.70 a.C.) rompe com a Academia (c. 87), buscando retornar às bases da filosofia de Platão, porém aproximando-a do pensamento estoico em um esforço de ecletismo. Antíoco viria a abandonar a Academia e inaugurar em Alexandria a sua própria escola filosófica. Enesidemo de Cnossos (séc. I a.C.), em razão do rumo dogmatizante impresso por Filon, também viria a romper com a Academia (c.90-80). Enesidemo funda uma nova escola, que 
denomina pirrônica, resgatando a figura de Pirro de Élis (360-270 a.C.) por ser o melhor exemplo de quem teria seguido o modo de vida cético. É neste contexto que se situa a nossa principal fonte sobre a Nova Academia: em sua obra, Cícero autointitula-se um seguidor da Academia e, a partir deste ponto de vista, expõe tanto a filosofia quanto a história da tradição neoacadêmica. No entanto, a sua concepção do pensamento acadêmico está bastante afastada tanto temporal quanto filosoficamente dos principais representantes da tradição acadêmica, Arcesilau e Carnéades.

Enesidemo critica o pensamento acadêmico Filon por conta da relativização da epoche. Este filósofo aceita um critério aproximado de verdade, assumindo um "falibilismo moderado" de modo doutrinário. Com isso, imprime um rumo dogmatizante na Academia, ao mesmo tempo em que aceita a infiltração de doutrinas estoicas em seu próprio sistema. Deste modo, a significância da academia com Filon se resumiria a "estoicos em luta contra estoicos" ${ }^{24}$. Portanto, Enesidemo teria rompido com a Academia de modo a resgatar a prática cética à sua significância própria, a qual teria sido corrompida por Filon. No entanto, não se sabe se Enesidemo, com o seu rompimento da Academia e com o resgate da figura de Pirro, estaria efetivamente buscando criar algo novo, ou simplesmente retornar às origens da Nova Academia de Arcesilau e Carnéades. Contudo, há semelhanças fundamentais entre o ceticismo pirrônico fundado por Enesidemo e o pensamento da Nova Academia. O elemento que sugere mais fortemente esta filiação é o próprio uso "cético" ou dialético da epoche.

Nesta breve exposição do pensamento da Nova Academia, nota-se que não há referências ao conceito de dúvida: os seus termos técnicos são outros; em ampla medida, tomados de empréstimo da filosofia estoica, como epoche, aparallaxia, assentimento, impressão, critério, etc. Nas principais fontes antigas, não se descreve a prática de Arcesilau ou de Carnéades como uma prática da

24 Esta seria uma frase do próprio Enesidemo, relatada por Photius (sec. IX), que afirma ter lido os Discursos Pirrônicos de Enesidemo e relata as suas teses. 
dúvida. Como veremos mais adiante (quinto capítulo), a exceção é a exposição de Cícero da tradição acadêmica, especialmente em seus Academica.

\title{
2.1
}

\section{Breve descrição do ceticismo pirrônico}

\begin{abstract}
Nesta seção, nossa intenção é descrever os elementos essenciais do ceticismo pirrônico tal como é exposto por Sexto Empírico, principalmente nos capítulos iniciais das Hipotiposes Pirrônicas, Livro I. É preciso notar que não tentaremos oferecer uma definição de ceticismo, mas apenas esboçar algumas das suas características que consideramos serem essenciais. Esta ressalva torna-se relevante diante do fato de que tanto as suas características essenciais ou principais, quanto o próprio conceito de ceticismo são objeto de extensa e contínua controvérsia.
\end{abstract}

Nas primeiras linhas das Hipotiposes Pirrônicas, Sexto apresenta o modo como entende "a principal diferença entre as escolas filosóficas" (HP, I, 1-4):

$\mathrm{O}$ resultado natural de qualquer investigação é que aquele que investiga ou bem encontra o objeto de sua busca, ou bem nega que seja encontrável e confessa ser ele inapreensível, ou ainda persiste em sua busca. O mesmo ocorre com os objetos investigados pela filosofia, e é provavelmente por isso que alguns afirmaram ter descoberto a verdade, outros, que a verdade não pode ser apreendida, enquanto outros continuam buscando. Aqueles que afirmam ter descoberto a verdade são os "dogmáticos", assim são chamados, especialmente, Aristóteles, por exemplo, Epicuro, os estoicos e alguns outros. Clitômaco, Carnéades e outros acadêmicos consideram a verdade inapreensível, e os céticos continuam buscando. Portanto, 
parece razoável manter que há três tipos de filosofia: a dogmática, a acadêmica e a cética ${ }^{25}$.

Os filósofos dogmáticos, como Aristóteles, Epicuro e os estoicos, sustentam um resultado afirmativo para a sua busca da verdade. Clitômaco, Carnéades e outros acadêmicos, na medida em que mantêm um resultado negativo para a busca - pois afirmam ser a verdade inapreensível - também dogmatizam; sustentam a posição de um "dogmatismo negativo". Os céticos, por sua vez, persistem em sua busca, sendo o único "resultado" obtido da sua investigação não afirmar nem negar nada a respeito da matéria investigada. Sexto afirma haver uma diferença fundamental entre o ceticismo e o pensamento dogmático, tanto positivo da filosofia por assim dizer "tradicional", quanto negativo de alguns acadêmicos (nota-se que Sexto não meniciona Arcesilau): apenas os céticos ainda investigam, e sustentam nenhuma posição acerca da verdade filosófica da matéria investigada ${ }^{26}$.

Na exposição de Sexto Empírico, esta primeira caracterização do ceticismo reside na noção cética de skepsis (busca, investigação). Como não é capaz de encontrar um resultado, seja positivo, seja negativo para a sua investigação, o cético ainda investiga, poersiste na sua busca, sem sustentar nenhuma posição sobre a matéria investigada. O ceticismo distingue-se dos outros tipos de filosofia justamente por não encontrar um resultado para a sua investigação, e, deste modo, não sustentar nenhuma posição teórica sobre a matéria que investiga, nem elaborar ou manter qualquer doutrina a seu respeito. Os céticos, diferentemente dos que aderem aos outros tipos de filosofia, ainda investigam.

Portanto, nestas primeiras linhas das Hipotiposes, o ceticismo é apresentado como um dentre três tipos de filosofia, e, ainda, em conexão a algo mais amplo do que o próprio domínio da filosofia. Sexto entende os três tipos de filosofia como,

25Sexto Empírico, Hipotiposes Pirrônicas, I, 8-10. Doravante HP, seguido de livro e alínea. Citações de HP I 1-30, tradução de Danilo Marcondes (1997).

${ }^{26}$ Sexto mais adiante (p. ex. HP I, 16) tornará explícita a natureza da "matéria investigada" pela filosofia, sobre a qual o cético nada afirma nem nega. 
ao mesmo tempo, os "três resultados naturais de toda investigação", o que significa que a própria atividade filosófica pode ser entendida em relação à atividade investigativa e seus "resultados naturais". E, neste contexto, a especificidade do ceticismo, a característica que lhe é própria diz respeito não apenas à filosofia, mas ao processo de investigação de modo geral - o cético é um investigador que não encontra um resultado para a sua investigação e nela persiste.

Nas linhas seguintes, Sexto Empírico define o ceticismo como uma habilidade de oposição (dynamis anthithetiké). Neste sentido, o ceticismo pirrônico se caracteriza por uma habilidade. Esta é a definição oferecida por Sexto Empírico (HP I, 8):

O ceticismo é uma habilidade que opõe as coisas que aparecem e que são pensadas de todos os modos possíveis, com o resultado de que devido à equipolência nesta oposição tanto no que diz respeito aos objetos quanto às explicações, somos levados inicialmente à suspensão e depois à tranquilidade.

De acordo com esta definição, o cético caracteriza-se tão somente por possuir esta capacidade de oposição. O cético é quem contrapõe argumentos com um mesmo peso em matéria de persuasão ou convencimento, de modo que através do exercício desta capacidade encontra-se diante de um conflito equipolente entre teses excludentes. A partir daí, o cético é levado a suspender-se: diante do impasse ocorre a suspensão (epoche $)^{27}$.

Portanto, nas Hipotiposes o ceticismo é primeiramente descrito como um resultado natural da investigação, em que o investigador não descobre a verdade sobre o objeto investigado, e continua buscando; e como um procedimento investigativo, a através da sua capacidade antitética, o investigador opõe argumentos de peso igual, deparando-se com um impasse, sendo então levado à

27 No capítulo seguinte (seção 3.3), analisaremos a epoche pirrônica e os modos possíveis de se entendê-la em seus diferentes sentidos ou dimensões. 
suspensão e atingindo a tranquilidade. Deste modo, nota-se que as primeiras descrições do ceticismo estão relacionadas à investigação. O ceticismo é um dos resultados possíveis de toda investigação e diz respeito a uma capacidade investigativa, não consistindo em uma doutrina ou teoria; enquanto resultado e capacidade, o ceticismo tem uma natureza inteiramente prática, não teórica ou doutrinária.

Neste sentido, pode-se entender o ceticismo ou o caminho, a via cética (skeptike agoge), apenas como um procedimento investigativo, a qual possui uma conotação prática, enquanto a habilidade de executar um modelo investigativo. Em HP I, 11, Sexto Empírico afirma: “a definição do filósofo pirrônico está implicitamente contida naquela do caminho cético: ele é alguém que possui a habilidade supramencionada". O ceticismo, portanto, parece poder limitar-se a um procedimento investigativo, sendo o cético tão somente alguém que possui uma habilidade específica, sendo capaz de executá-la. Embora seja possível entender o ceticismo deste modo, veremos adiante que esta caracterização do ceticismo consiste apenas em um modo de entendê-lo, mas que não esgota todos os seus sentidos. Em resumo:

1) O ceticismo é um dos resultados naturais de toda investigação, e um dos três tipos de filosofia; um resultado filosófico que não encontra modos, ou que se encontra incapaz de afirmar ou negar nada sobre o objeto investigado, e faz com que o cético continue buscando;

2) O ceticismo caracteriza-se como a capacidade e a execução de um procedimento investigativo, que consiste em opor impressões, argumentos, e teses de modo a produzir um conflito equipolente em disputas sobre objetos não evidentes da investigação dogmática. A seguinte esquematização apresenta de modo claro as etapas do procedimento de investigação cética: 
Skepsis (investigação) $\rightarrow$ Zetesis (busca) $\rightarrow$ Diaphonia (conflito) $\rightarrow$ Isosthenia (problema do critério, equipolência) $\rightarrow$ Aporia (impasse) $\rightarrow$ Epoche (suspensão) $\rightarrow$ Ataraxia (tranquilidade) $\rightarrow$ Eudaimonia (felicidade). ${ }^{28}$

Nota-se que o modelo investigativo do ceticismo pirrônico tem como ponto de partida a investigação da verdade (skepsis). Ao buscar (zetesis) os modos correntes de se pensar uma determinada questão que o incomoda, o cético deparase com o conflito de doutrinas (diaphonia), no qual as respostas encontradas para uma determinada questão dividem-se entre teses contraditórias e excludentes, cujos argumentos têm um peso igual - são igualmente convincentes ou persuasivos (isosthenia). O conflito sustenta-se, pois 1) os critérios aduzidos por cada uma das partes para resolver o conflito, como são internos às próprias doutrinas em conflito, estão eles mesmos em disputa; e 2) devido à ausência de um critério externo aos argumentos propostos por cada lado, o conflito permanece, sem poder ser resolvido ou dissolvido o impasse (o chamado problema da ausência de critério, ver HP II, 14-79). Diante deste plano de equipolência entre teses excludentes, e devido à ausência de um critério que fosse capaz de resolvê-lo, o cético vê-se obrigado a abrir mão de uma teoria filosófica que pudesse dizer qual seria a verdade a repeito da sua questão, sendo então levado à suspensão do juízo (epoche). $\mathrm{O}$ cético não se pronuncia a favor de nenhum dos lados, de modo a nem afirmar nem negar nada acerca da questão. E da suspensão adviria, fortuitamente, como uma sombra segue o seu objeto, a tranquilidade, ou um estado de imperturbabilidade da alma (ataraxia).

Como indicamos acima, ao se pensar sobre a skeptike agoge pode-se ter a impressão de que o ceticismo estaria relacionado apenas ao processo de investigação. Tendo em vista que Sexto Empírico define o cético simplesmente como alguém que possui a capacidade de executar o "caminho cético", pode-se supor que o ceticismo limitar-se-ia a estratégias dialéticas e procedimentos argumentativos. De acordo com esta visão do ceticismo, o seu objetivo principal seria instalar-se em qualquer discussão que possua uma pretensão ao

28 MARCONDES, D. A tradição cética, s/d, p.8. 
conhecimento e à verdade e "neutralizá-la". Contudo, deve-se ter em vista que, de acordo com Sexto Empírico, a finalidade do ceticismo é encontrar a tranquilidade. O caminho cético para a tranquilidade, no entanto, não é através da decisão de controvérsias e disputas, tampouco através da construção de um entendimento dogmático, positivo sobre a matéria em questão. Pelo contrário, Sexto escreve que "a finalidade do cético é a tranquilidade em questões de opinião e a sensação moderada quanto ao que é inevitável".

Pois aqueles que mantêm uma opinião sobre se algo é por natureza bom ou mau estão sempre perturbados. Quando se encontram privados daquilo que consideram bom, sentem-se afligidos por algo naturalmente mau e passam a buscar aquilo que pensam ser bom. E ao obter isso se sentem ainda mais perturbados, já que ficam contentes de forma irracional e imoderada e passam a recear que as coisas mudem e percam aquilo que pensam ser bom. Mas, ao contrário, aqueles que não determinam serem as coisas naturalmente boas ou más, não as evitam nem as buscam avidamente, e, por isso, não se perturbam. (HP, I, 25-28.)

A finalidade do ceticismo, portanto, não diz respeito ao estabelecimento de um critério para a crença verdadeira ou para a crença plausível. Consiste apenas em obter a tranquilidade em matéria de opinião e a moderação a respeito do que é inevitável. Deste modo, a finalidade do ceticismo desvincula-se das investigações sobre o não aparente; não envolve crenças sobre o que estaria para além dos fenômenos ou sobre como as coisas seriam 'por natureza', i.e., para além do modo como aparecem. Portanto, a tranquilidade do cético diz respeito à ausência de opiniões dogmáticas e à moderação que o caminho cético lhe proporciona. E, neste sentido, a finalidade do ceticismo residiria no exercício do ceticismo. É ao exercitar ou praticar o ceticismo que se evita o dogmatismo e, deste modo, se conseguiria viver com tranquilidade e moderação.

Nota-se que a distinção entre fenômeno (o que aparece) e o que é não evidente (o que estaria para além ou por trás do que aparece, como a sua causa ou essência) é fundamental na exposição de Sexto. Segundo Sexto, o cético suspende o juízo a respeito dos "objetos não evidentes da filosofia dogmática" (HP I, 16). Com a experiência de exercer a sua habilidade específica, em vez de perseguir na 
busca pela verdade das coisas em sua "natureza real", o cético limita-se a seguir o que aparece. É este modo de vida que, no decorrer da sua experiência, aparece ao cético como conduzente à tranquilidade da alma (ataraxia). $\mathrm{O}$ cético confere o seu assentimento somente àquilo que lhe "afeta em sua passividade" (pathos), ou seja, às afecções passivas e involuntárias. Sexto apresenta da seguinte forma o assim chamado "critério do ceticismo" (HP, I, 21-22):

O termo "critério" é usado em dois sentidos: no primeiro, os critérios geram crenças sobre a realidade ou não de algo (discutiremos estes critérios ao refutá-los), e no segundo, temos critérios de ação, de acordo com os quais em nossa vida cotidiana praticamos certos atos e evitamos praticar outros, e é destes critérios que tratamos aqui. Dizemos então que para os céticos o critério é aquilo que aparece, querendo dizer com isso as impressões sensíveis, uma vez que estas consistem em sensações e afecções involuntárias e logo não estão sujeitas ao questionamento. Portanto, presumivelmente ninguém discutirá se uma coisa existente tem esta ou aquela aparência, o que se discute é se de fato corresponde àquilo que aparece.

O que se discute dogmaticamente não é o próprio aparecer dos objetos que aparecem, isto que ocorre inclusive devido a afecções involuntárias, mas a suposta objetividade subjacente ao que aparece. Deste modo, um critério de ação é dogmático somente na medida em que se baseia não naquilo que aparece, do modo como aparece, mas no que estaria subjacente ao que aparece, como a sua causa ou essência, a sua "natureza real". O pirrônico não rejeita as aparências ou fenômenos, entendidos aqui como algo que lhe afeta involuntariamente, mas, pelo contrário, são os fenômenos ou "aquilo que aparece" que constituem o critério do ceticismo. O que o cético se abstém de fazer é julgar se os fenômenos de fato correspondem a certa realidade subjacente: o que frequentemente está em disputa não é que aquilo que aparece se mostre do modo como aparece, mas uma realidade oculta ou obscura à qual os fenômenos corresponderiam em sua natureza real. Deste modo, o cético confere o seu assentimento aos fenômenos, mas não ao objeto não evidente que se supõe estar subjacente ou "por trás" daquilo que aparece. $\mathrm{O}$ critério pirrônico, portanto, consiste em critérios práticos, tanto para a ação, quanto para a inteligência, de acordo com os quais em nossa vida cotidiana praticamos certos atos e evitamos praticar outros. O critério de ação do ceticismo 
baseia-se naquilo que aparece, e que Sexto expõe de acordo com um esquema dividido em quatro partes (HP I, 23-24):

Aderindo, portanto, ao que aparece, vivemos de acordo com as normas da vida comum, de modo não dogmático, já que não podemos permanecer totalmente inativos. Essas práticas que regulam a vida comum parecem ser de quatro tipos, consistindo primeiro na orientação natural, depois no caráter necessário das sensações, em seguida nas leis e costumes da tradição, e por fim na instrução nas artes. Pela orientação natural somos capazes de percepção e de pensamento; é devido ao caráter necessário das sensações que a fome nos leva à comida e a sede à bebida; dadas as leis e os costumes da tradição consideramos em nossa vida cotidiana a piedade como um bem e a impiedade como algo de ruim; graças à instrução nas artes não permanecemos inativos naquelas que adotamos.

Sendo o critério do ceticismo a adesão ao que aparece, há quatro práticas fundamentais que "regulam a vida comum". Estas quatro práticas podem ser caracterizadas como guias práticos de ação. Desta maneira, baseando-se no critério cético para o bem viver, o pensador cético seria capaz de reorganizar inteiramente o seu modo de vida, deixando de lado todo elemento dogmático ou não evidente na condução da sua vida. Em decorrência da sua prática, o cético é levado a ter uma profissão, a conviver bem com os seus concidadãos, a respeitar os costumes e práticas religiosas da sua comunidade, e a orientar-se de acordo com sua sensibilidade e inteligência. Os céticos vivem em decorrência do seu ceticismo: a sua vida é moldada pelo seu ceticismo. O critério cético não se baseia em juízos sobre objetos não evidentes, e que estão sujeitos às infinitas controvérsias entre as diversas escolas de pensamento - não é teorético, assertórico ou dogmático.

Tendo em vista o critério e a finalidade do ceticismo, através dos quais o cético organiza toda a sua vida prática apoiando-se exclusivamente no que aparece de modo a obter a tranquilidade e a moderação, nota-se que a skeptike agoge possui um caráter nitidamente ético - o caminho cético, para além de um procedimento investigativo, consiste em um modo de vida. O ceticismo, portanto, poderia ser entendido como um procedimento de investigação que busca examinar as teses da filosofia dogmática e denunciá-las como sem fundamento; mas, ao 
mesmo tempo, é uma filosofia ética e um modo de vida, de modo que não se limita a um procedimento investigativo. Neste sentido, é possível caracterizar o ceticismo em linhas gerais de acordo com dois aspectos ou dimensões:

1) A dimensão prático-dialética. Como o cético não defende nenhuma doutrina ou teoria, e tampouco propõe argumentos com o efeito de endossálos ou sustentá-los, pode-se dizer que o cético não adota nenhuma posição teórica. A sua estratégia argumentativa consiste tão somente em atacar a pretensão de verdade das doutrinas dogmáticas. Ao opor-lhes argumentos contrários, que busca possuírem um mesmo peso em matéria de persuasão, o cético neutraliza os argumentos dogmáticos, de modo a apenas levantar um questionamento a respeito da legitimidade da investigação dogmática;

2) A dimensão prático-ética. $\mathrm{O}$ ceticismo consiste em um modo de vida, com o qual busca alcançar a tranquilidade, e não propriamente em uma teoria ou doutrina; não se caracteriza como a defesa teórica de uma posição doutrinária, sendo simplesmente uma prática, ou, em sua relação à "assim chamada filosofia", uma "prática intelectual" através da qual busca o bem viver.

Estas dimensões constituem a significância do pirronismo, e não podem ser analisadas como dois componentes independentes. Nas palavras de Williams (1988b, p. 551), “o ceticismo pirrônico se distingue pelo fato de que resiste à análise em um componente teórico e um componente prático ou prescritivo; e esta resistência deriva do Pirronismo não possuir nenhuma base teórica, sendo primária a prática, e não a teoria”. Pensar o ceticismo como uma teoria que leva a uma prática seria equivocado, tanto quanto, inversamente, pensar que seria uma prática com consequências teóricas. Deste modo, pode-se tentar caracterizar o ceticismo pirrônico da seguinte forma: 
1) ceticismo é um dos resultados naturais de toda investigação, em que não se encontra o objeto buscado, e continua-se buscando;

2) ceticismo é uma capacidade (dynamis) de oposição, consistindo em uma prática filosófica que possui um procedimento investigativo próprio;

3) ceticismo é um modo de vida, cujo fim é a tranquilidade;

4) ceticismo é uma adesão (hairesis) filosófica.

As dimensões ética (3) e investigativa (1-2) do ceticismo dizem respeito a apenas uma "prática intelectual", denominada via ou caminho cético (skeptike agoge): a prática filosófica do ceticismo confunde-se com a prática comum, com a vida cotidiana do filósofo cético. Esta indissociabilidade das suas dimensões prático-ética e prático-dialética explicita uma característica própria do pirronismo, que é descrita por Michael Williams como "ceticismo sem teoria" (1988; 2014). O pirronismo desprende-se de compromissos teóricos, aos quais se esposa nas filosofias dogmáticas. $\mathrm{O}$ ceticismo não sustenta nenhuma teoria, e tampouco consiste em uma "tese epistemológica", seja positiva ou negativa. Como vimos acima, sustentar uma tese sobre a verdade, ainda que negativa, é o ponto principal que para Sexto Empírico distinguiria os céticos pirrônicos dos filósofos acadêmicos. Segundo Williams (1988b, p. 580):

[...] estamos muito acostumados a pensar no ceticismo como uma tese no interior da epistemologia, ao passo que, para Sexto, todas as posições epistemológicas, incluindo o ceticismo teórico, são apenas mais coisas sobre as quais ser cético.

O pirronismo não é uma tese epistemológica. Deste modo, o ceticismo pirrônico não designa um lugar possível de se ocupar no interior de uma epistemologia. A prática cética de suspender-se de conflitos entre doutrinas 
dogmáticas é um modo pelo qual o cético continuamente exerce e reafirma a sua isenção em relação a toda e qualquer teoria sobre a verdade. O pirronismo é isento de compromissos epistemológicos, e a sua prática consiste justamente em desprender-se de tais compromissos. Segundo Bicca (2012, pp. 180-81), o pirronismo tem em vista "a purgação de todo compromisso cognitivo ou teorético da vida humana". Nesta medida, claramente o ceticismo pode possuir e historicamente possui uma relevância especial para o conhecimento e para a teoria do conhecimento. Entretanto, esta é uma consequência do ceticismo para os seus adversários, i.e., expressa a sua significância vista desde fora, e não a partir dele próprio: para os filósofos dogmáticos, o ceticismo é uma ameaça fundamental para o conhecimento filosófico que precisa ser respondida à altura.

Portanto, pode-se considerar que o ceticismo levanta questionamentos sobre a assim chamada epistemologia, no entanto, como afirma Naess: "O pirronismo não é apenas uma atitude de questionamento epistemológico" (1969, p.33). Pensar que o fundamental do ceticismo diria respeito a "questões epistêmicas", ou à "problemática epistemológica" é um modo de não atentar para a sua significância própria e dela desviar-se. Nas palavras de Williams (2010, p. 299):

[o ceticismo pirrônico] desafia algo que é mais profundo que a epistemologia técnica e que dá origem a ela: a nossa parcialidade epistêmica a favor de nós mesmos enquanto os juízes de como as coisas realmente são.

Segundo Williams, é legítimo pensar que o ceticismo representa um desafio. No entanto, o desafio cético não se voltaria fundamentalmente contra a epistemologia, e sim para nós mesmos. Ou seja, o ceticismo pirrônico estaria relacionado a algo mais profundo e fundamental em nossa própria natureza, algo que seria independente de qualquer teoria do conhecimento, e estaria inclusive na origem das teorias do conhecimento - algo anterior à epistemologia, e não interior a ela. Desafiar a nossa parcialidade epistêmica consistiria, desta forma, no exercício espiritual com o qual o ceticismo está envolvido. Esta seria propriamente a prática filosófica do ceticismo. 
A significância da prática cética não se resume em colocar teorias em oposição, analisar seus argumentos, ou chegar à suspensão. Fundamentalmente, o ceticismo tem em vista, através do exercício destas habilidades, confrontar uma atitude epistêmica que já se encontra presente em nós mesmos. Deste modo, o ceticismo pode ser entendido na linhagem da exortação délfica do "conhece-te a ti mesmo": ao confrontar as filosofias dogmáticas e colocá-las lado a lado em seus conflitos, o cético pratica não somente a expurgação da filosofia dogmática; o cético exercita-se, através da sua prática filosófica, em suspender-se da parcialidade epistêmica que se encontra nele mesmo.

Bernard Williams (1985, p. 204), ao frisar que o ceticismo não se resume a questionamentos epistemológicos, escreve: "O ceticismo ocupa-se basicamente com a dúvida, mas não com (a negação) do conhecimento". A significância do ceticismo não diz respeito à negação do conhecimento, nem pode se reduzir a uma tese epistemológica, mas tampouco se ocupa com a dúvida. Nota-se que nesta breve apresentação do ceticismo, que está baseada na descrição do cético por Sexto Empírico no início das Hipotiposes Pirrônicas, não se pode encontrar nenhuma ocorrência do conceito de dúvida. Já isto sugere que a significância do ceticismo deve ser pensada de outro modo, não a partir de uma noção que lhe está ausente.

À guisa de conclusão pode-se resumir as descrições fundamentais do ceticismo pirrônico por Sexto Empírico da seguinte forma: 1) como um dos três tipos de filosofia, de acordo com o resultado da investigação: não se encontra o objeto buscado, e continua-se buscando; 2) como uma habilidade de oposição através da qual é gerada a aporia entre as teorias dogmáticas investigadas; 3) como um caminho ou procedimento investigativo, cujas etapas vão da skepsis à ataraxia e à eudaimonia; 4) como caminho investigativo descreve, ao mesmo tempo, um modo de vida e uma ética. Tanto em sua dimensão investigativa quanto ética, de se buscar viver bem, o ceticismo pode ser considerado uma "prática filosófica" una e coesa, em que não há cisão entre teoria e prática, entre investigação e guia de conduta. Sendo inteiramente uma prática intelectual, não 
envolve nem "doutrina", nem "prescrição": não se ensina, nem se recomenda o ceticismo, apenas pratica-se o ceticismo. O ceticismo diz respeito a uma adesão filosófica específica, a qual possui características próprias, consistindo em uma das alternativas possíveis para aquele que investiga. Neste sentido, não é preciso negar ao ceticismo uma identidade filosófica, pois ele a possui, embora não se possa expressá-la na forma de um corpo doutrinário, de uma tese ou conteúdo filosófico, mas apenas como procedimento, caminho, ou como um modo de vida.

Portanto, Sexto Empírico não faz uso das palavras gregas correspondentes à dúvida para descrever o ceticismo, nem se pode identificar claramente, para além da ausência dos termos correspondentes à dúvida, qualquer referência ao conceito de dúvida na caracterização do ceticismo pirrônico. Por que Sexto não se refere à noção de dúvida ou utiliza nenhum termo correspondente à dúvida em grego para caracterizar o ceticismo? Será que em algum lugar da sua descrição o ceticismo confunde-se com a dúvida? Para tentar responder a estas perguntas, cabe analisar o que se entende por dúvida, para se pensar por que este conceito está ausente da descrição do ceticismo de Sexto Empírico, e de quais modos, a despeito deste fato textual, seria possível interpretar a filosofia cética através da dúvida. 


\section{3}

\section{Dúvida e Ceticismo}

Neste capítulo, pretende-se mostrar que dúvida e ceticismo dizem respeito a fenômenos independentes entre si. A extensão que a sinonímia entre dúvida e ceticismo atinge será exemplificada em 4.1, onde mostramos como até mesmo alguns principais comentadores da filosofia cética que buscam diferenciá-la da dúvida terminam por reinserir esta noção em sua compreensão do ceticismo. Em 4.2 analisamos o conceito de dúvida através de alguns dos modos pelos quais o termo é entendido e utilizado pela linguagem comum, de modo a examinar as diferentes formas de se entendê-lo e aproximarmo-nos do seu significado próprio. Em 4.3, cotejamos o ceticismo com a acepção de dúvida que consideremos ser a que melhor expressa o seu significado próprio, de modo a mostrar os principais modos pelos quais se pode ver uma distinção nítida e fundamental entre ceticismo e dúvida.

Ao se colocar a dúvida no lugar da aporia, entende-se que o ceticismo advém do ato de duvidar. O cético suspende-se porque duvida. Neste sentido, o ceticismo nasceria da indecisão e, a partir deste entendimento, o procedimento cético transforma-se no exercício de colocar tudo em dúvida. Ao se colocar a dúvida no lugar da epoche, a dúvida torna-se o resultado do ceticismo; o ponto de chegada da investigação cética. Por consequencia, em vez de suspender-se, o cético buscaria estar sempre em dúvida, sendo um indivíduo que se mantém em estado de constante hesitação e perplexidade.

Portanto, insere-se a dúvida tanto no início quanto no fim do ceticismo. Como veremos (Cap. 6), já Montaigne sustenta que duvidar consistiria tanto na tarefa quanto no fim do ceticismo. Com estas transformações, o cético torna-se quem começa pela dúvida para terminar com a dúvida. Consequentemente, em última análise, o ceticismo deixa de ser uma adesão filosofica ou um dos tipos de 
filosofia, como é descrito por Sexto, para tornar-se apenas um exercício de futilidade, algo sem razão de ser e sem propósito; uma marca de inconsequência intelectual e até mesmo sintoma de uma psicopatologia ${ }^{29}$.

\section{1}

\section{A gênese do cético}

Como veremos a seguir, de acordo com vários intérpretes contemporâneos o conceito de dúvida poderia ser introduzido na filosofia cética já em um momento anterior ao ceticismo propriamente: o ceticismo seria um modo específico de se lidar, resolver, solucionar a dúvida, de modo que diria respeito a uma atitude específica que se mantém em relação a esta. No entanto, é digno de atenção que estes sejam os principais intérpretes que buscam distinguir entre dúvida e ceticismo. Contudo, em meio à busca de traçar tal distinção - que é inclusive a sua intenção declarada -, terminam por conceder de alguma forma um papel para a dúvida na "gênese do cético". E, consequentemente, como inserem esta noção em sua origem, atribuem à dúvida um papel central na significância própria do ceticismo pirrônico. Deste modo, a narrativa de Sexto da "gênese do cético" pode ser tomada como um exemplo ilustrativo de como a noção de dúvida está profundamente arraigada em nossa compreensão da filosofia cética, bem como, a partir da modernidade, em nossa compreensão da filosofia de uma maneira geral.

Como reconhece Olaso (1975), quem primeiramente chamou a atenção sobre a narrativa de Sexto sobre a gênese do cético foi Arne Naess (1968, p. 28):

29 K. Jaspers, Psiolopatologie apud Naess (1969). 
É importante distinguir entre dúvida e suspensão do juízo. A suspensão do juízo é a característica básica do cético quando confrontado com asserções dogmáticas. [...] Não há razão para postular um estado de dúvida como um ingrediente principal, ou característica que acompanha constantemente a mente de alguém que suspende o juízo. E, no entanto, é precisamente essa identificação da dúvida com a suspensão que tão frequentemente obscurece as referências aos céticos gregos.

Não que na gênese de um cético a dúvida e a indecisão não desempenhem nenhum papel; com efeito, as pessoas de talento da narrativa de Sexto foram levadas ao ceticismo precisamente pela dúvida inquietante e indecisão neles provocadas pelas contradições nas coisas. E a ataraxia que Sexto descreve pretende-se como um meio de eliminar exatamente aquele estado de inquietude.

Nota-se que, no primeiro parágrafo da passagem, Naess distingue claramente entre dúvida e ceticismo, apontando para a importância de não se confundi-los. Na sequencia, entretanto, retorna à temática da dúvida ao pensar sobre a gênese do cético: "as pessoas de talento da narrativa de Sexto foram levadas ao ceticismo precisamente pela dúvida inquietante e indecisão neles provocadas pelas contradições nas coisas". Sexto Empírico não afirma que a gênese do cético estaria relacionada à dúvida. No início das Hipotiposes (I, 12) Sexto descreve as origens do ceticismo através da passagem do homem "précético" (Olaso) ao "cético maduro" (Naess). O cético inicia a sua vida filosófica com a intenção de descobrir a verdade e a falsidade das coisas:

Homens de talento, perturbados pela discrepância (anomalia) nas coisas e em aporia (aporountes) a respeito de que alternativa aceitar, foram levados a indagar sobre as coisas verdadeiras e sobre as falsas, esperando encontrar a tranquilidade ao resolver esta questão. O princípio básico do ceticismo é o de opor a cada explicação outra equivalente, porque acreditam que, assim, deixarão de ter uma atitude dogmática $(H P, \mathrm{I}, 12)$.

A anomalia encontrada nas coisas causa uma perturbação no pensamento, tornando-o perplexo ao não ser capaz de determiná-las, de encontrar a verdade e a falsidade a seu respeito. Pode-se notar que na exposição de Sexto, o cético pirrônico não se diferencia em sua gênese de qualquer outro filósofo, pois, incomodado com alguma questão, busca investigá-la e conhecer a verdade a seu 
respeito. Tal como qualquer outro pensador em movimento de lançar-se a filosofar, o cético espanta-se com alguma questão, assombra-se com a "anomalia nas coisas", sentimentos que o levam então a investigá-las mais detidamente. Ao buscar (zetesis) um caminho nas opiniões das escolas filosóficas para encontrar a verdade ou a falsidade acerca do que investiga, a "habilidade especial" do cético entra em cena de modo decisivo.

Tendo lançado-se a filosofar com o objetivo de decidir acerca da verdade ou falsidade das impressões sensíveis de modo a alcançar com isso a tranquilidade, encontrou-se diante da equipolência nas controvérsias (isosthene diaphonian), e, sem poder decidir sobre isto, adotou a suspensão, e, em consequência da suspensão, seguiu-se, como que fortuitamente, a tranquilidade em relação às questões de opinião. $(H P, \mathrm{I}, 26)$

Ao deparar-se com as controvérsias das opiniões filosóficas (endoxa) acerca da questão que investiga, a habilidade especial do cético apresenta-se como um impedimento para julgar a respeito das matérias em questão da filosofia dogmática. O cético não é capaz de determinar a verdade e a falsidade sobre a questão que originalmente o perturbava, mas, pelo contrário, encontra infindáveis controvérsias a seu respeito. Vindo a descobrir que a questão que lhe perturba é do interesse das diversas escolas filosóficas, nota que cada escola desenvolve a sua própria explicação, de acordo com uma doutrina compreensiva sobre a realidade. Sendo díspares as explicações que oferecem para o mesmo fenômeno, caberia ao cético preferir uma delas, avaliar cada explicação dada e pesar os seus argumentos. Neste momento, em que se encontra diante das inúmeras controvérsias filosóficas e seus infindáveis conflitos, abre-se um amplo terreno em que passa a exercer a sua "habilidade especial". Em desacordo constante, frequentemente uma escola em conflito com todas as demais, as explicações e seus argumentos excluem-se mutuamente, lhe parecendo serem igualmente persuasivos: nenhuma opinião prevalece.

Quando passa a contrapor os diferentes argumentos filosóficos, cai em perplexidade a respeito de qual dentre as diferentes escolas e doutrinas preferir. É 
então que ocorre algo de radical; uma experiência que deixaria marcas profundas em seu espírito e determinaria fundamentalmente tanto a sua atitude filosófica quanto o seu modo de vida. Diante do impasse que averigua haver entre as teorias (que se torna manifesto devido à sua habilidade especial), é levado à suspensão diante das controvérsias: o conflito mostra-se estar em um plano de equipolência, não havendo meios ou critérios para decidir a disputa em questão. O caminho para o dogmatismo lhe é bloqueado. Portanto, o procedimento cético se inicia com a skepsis, ocasionada pela perturbação com a anomalia nas coisas. Ao investigar as endoxa, o cético cai em aporia a respeito de qual doutrina preferir: não está em um estado de dúvida, mas em um estado aporético (aporountes).

Em El Significado de la duda escéptica (1975), Ezequiel de Olaso afirma:

O cético começa, certamente, por duvidar, diante de razões que lhe parecem sempre insuficientes; mas justamente quando descobre que não há critério para discernir entre as opiniões em conflito e que a abstenção do seu próprio juízo ou assentimento é seguida pela tranquilidade, abandona esta dúvida espontânea, efetivamente angustiante, através da suspensão que lhe traz tranquilidade.

De acordo com Olaso, o indivíduo "pré-cético" poderia ser descrito através da dúvida e da indecisão. Na medida em que busca a verdade nas diversas escolas e suas doutrinas, Olaso considera que o "cético imaturo", em suas investigações e buscas iniciais, estaria em um estado de dúvida; indeciso a respeito de qual escola preferir, qual doutrina julgar como verdadeira. Olaso considera que a dúvida estaria no início do filosofar para o investigador pré-cético - o cético começa por duvidar - mas que, ao se tornar um cético madura, abandonaria esta dúvida espontânea através da suspensão (epoche).

A epoche ou suspensão está para além da dúvida porque é - ou busca ser - uma solução para ela. Não surge no processo de conhecer, senão no processo de preferir um - autêntico - dentre vários conhecimentos que se nos oferecem, sendo uma reação à impossibilidade de encontrar um critério de preferência fundado racionalmente. (Olaso, 1975, p. 35) 
Com esta definição, Olaso considera ter feito a distinção entre dúvida e suspensão: a dúvida estaria na gênese do ceticismo, mas o cético responderia à dúvida com a suspensão. Deste modo, a epoche surgiria em relação à dúvida, consistindo em uma solução para ela. No entanto, como poderia a epoche estar "para além" da dúvida, como Olaso afirma, se seria justamente uma solução para ela? Eis como Olaso desenvolve a questão:

O homem que às vezes é acometido pela dúvida a respeito de uma opinião sua, ou que é induzido a colocá-la em dúvida, todavia não deixou de ser, por isso, um dogmático. É preciso saber como irá resolver a dúvida. E será cético pirrônico somente se o fizer mediante a suspensão. Segue-se que "dúvida" não se opõe necessariamente a "dogma", nem duvidar ocasionalmente a respeito de certas e determinadas coisas exime de dogmatismo ou leva ao ceticismo. (Olaso, 1975, p. 33)

A dúvida não é característica nem do ceticismo, nem do dogmatismo; a “dúvida espontânea” não se opõe, necessariamente, a um ou outro. Certamente, qualquer indivíduo pode encontrar-se em um estado de dúvida e indecisão ocasionalmente. Mas, de acordo com Olaso, o conceito de dúvida seria capaz de explicar a gênese tanto do filósofo dogmático quanto do filósofo cético. A dúvida poderia marcar a indecisão de um "dogmático imaturo" diante da controvérsia entre escolas e doutrinas, que ao esposar uma doutrina específica, dogmático teria encontrado a sua "solução dogmática" para a dúvida, tornando-se, com isso, propriamente um filósofo dogmático. No caso do indivíduo protocético, a sua resposta para a dúvida não é, certamente, a adesão a uma doutrina, mas a suspensão do juízo: esta seria a sua forma de responder à dúvida ou de "solucionála”. Em seguida, Olaso concluiu: "Desejo assinalar que o característico do cético não é colocar em dúvida a opinião dos outros às vezes a respeito de determinados tipos de coisas, senão duvidar sempre e em todos os casos”.

Pode-se tirar duas conclusões da leitura de Olaso, que dizem respeito à 1) gênese do ceticismo e à 2) função da dúvida para o filosofar em geral. 
Primeiramente, a dúvida estaria na gênese do ceticismo, sendo a epoche uma solução para a dúvida que ocorre "sempre e em todos os casos", e não para a “dúvida espontânea”, que pode ocorrer em todos os indivíduos, às vezes e a respeito de determinadas questões. Como para Olaso a epoche decorre da dúvida, e o cético sempre se suspende, igualmente buscaria o cético sempre e em todos os casos duvidar. Esta leitura, além de não encontrar apoio textual em Sexto Empírico, parece ser contrária às próprias intenções de Olaso, pois afirma que o seu objetivo seria "esclarecer a confusão entre a suspensão do juízo e a dúvida" (1975, p. 28), mas em seguida caracteriza o cético como aquele que duvida sistematicamente, de modo que reinstala a confusão entre dúvida e ceticismo, em vez de esclarecê-la.

Em segundo lugar, pode-se pensar que, para Olaso, a dúvida se situaria no início do filosofiar e estaria na gênese da filosofia, tanto para o filósofo cético quanto para o dogmático. A “dúvida espontânea" pode acometer a todos, por isso “é preciso saber como se irá resolver a dúvida". Deste modo, a dúvida poderia ser considerada a etapa inicial do filosofar em geral, bem como o divisor de águas entre o ceticismo e o dogmatismo. Neste sentido, ceticismo e dogmatismo diriam respeito, portanto, a diferentes modos de se lidar com a "dúvida", de maneira que, com efeito, a dúvida estaria no ínício do filosofar. Esta leitura, além de não encontrar apoio textual em Sexto Empírico, pode ser considerada anacrônica: no contexto da filosofia grega antiga não se descreve o início do filosofar através da noção de dúvida.

De modo similar a Olaso, buscando distinguir entre dúvida e suspensão, Michael Williams escreve (2010, p. 289):

Para Sexto, o ceticismo é o antídoto para a dúvida. Os céticos pirrônicos começam como "homens de talento" que "estão perturbados pelas anomalias nas coisas e perplexos sobre que alternativa adotar" (HP I, 12). Ao investigar as questões sistematicamente, veem que as anomalias são ainda mais difundidas do que haviam imaginado. Isto os leva à ampla suspensão do juízo e (para a sua surpresa) à paz de espírito. 
Em Descartes and the Metaphysics of Doubt (1986, p. 119) Williams é ainda mais explícito em relação ao papel da dúvida na gênese do ceticismo:

Como Sexto narra, o cético começa como alguém que duvida, mas não termina como um indivíduo que duvida. A capacidade do cético para a suspensão do juízo (epoche) é o seu remédio para a dúvida, não um meio de induzi-la.

Para Williams, ao contrário da dúvida cartesiana - e da interpretação de Olaso -, o ceticismo pirrônico consistiria em uma "extensão da dúvida comum", a qual descreve como "um estado em que desejamos conhecer a verdade, mas não podemos decidir onde está". Contudo, segundo Williams seria significativa a extensão que o cético conferiria à 'dúvida comum” (1986, p. 120):

Embora a suspensão do juízo clássica não seja dúvida, ela é alcançada por meios que envolvem uma extensão da dúvida comum, não-filosófica, o tipo de dúvida que é o resultado da exposição a opiniões conflitantes, cada uma plausível ao seu modo.

A proposta principal de Williams neste artigo, bem como em diversos outros textos é distinguir o ceticismo pirrônico da dúvida cartesiana. Williams o faz, sobretudo, contrapondo a dúvida "não natural" (unnatural) cartesiana à dúvida cética que seria uma extensão da dúvida comum, "não filosófica". No entanto, desta maneira Williams parece restringir o significado da dúvida comum a um "tipo de dúvida", que se assemelharia à noção de "conflito equipolente" utilizada pelo ceticismo pirrônico. No entanto, o conceito comum de dúvida não envolve a noção de um conflito equipolente: a "dúvida comum" não parece se assemelhar a este tipo específico de dúvida descrito justamente através de um termo técnico do ceticismo. Williams, que sustenta haver uma distinção radical entre o ceticismo pirrônico e a dúvida cartesiana, parece conceder que houvesse uma relação entre o ceticismo e a "dúvida comum" por conta da narrativa de Sexto sobre a gênese do cético. Mas, como veremos adiante, é precisamente em seu "sentido comum" que 
a distinção entre dúvida e ceticismo pode ser mais nitidamente traçada, e se pode ver não possuir lugar no ceticismo pirrônico. Em nota à passagem citada acima, Williams refere-se novamente a HP I, 12 para sustentar a sua afirmação de que "o cético começa como um indivíduo que duvida", de modo que a suspensão seria o "remédio" do cético para a dúvida.

O problema do investigador "protocético" é resolvido ao entender que não precisa preferir uma escola, não precisa emitir um juízo sobre a verdade, aos poucos amadurecendo o ceticismo e suspendendo o impulso a preferir e a julgar. Como o próprio Williams (1986, p. 119) afirma: “adquirir as capacidades céticas distintivas para a isosthenia e epoche atenua, ou mesmo elimina, o impulso a realmente conhecer como as coisas são". A suspensão seria a "resposta" ou "solução" cética para a aporia e para o impasse em que se enreda a filosofia dogmática, não para a dúvida. Da mesma forma que a epoche cética não é uma solução para a dúvida, mas a suspensão dos dogmas filosóficos, o ceticismo não é o "antídoto" para a dúvida, mas um "remédio" ou solução para o dogmatismo. Portanto, em HP I, 12 Sexto Empírico não se refere à dúvida, mas à aporia: o cético está em aporia diante da controvérsia entre as escolas dogmáticas. Nesta passagem, não há nenhuma indicação de que a dúvida desempenhe um papel na gênese do cético ou esteja na origem do ceticismo.

Como a introdução da dúvida na gênese do cético diz respeito à confusão da dúvida com a aporia, deste modo insere-se a dúvida não apenas no início do ceticismo, mas no interior da prática cética, como uma etapa integrante do seu procedimento (skeptike agoge). Segundo Paganini (2008):

Para indicar o estado de espírito do pirrônico, que fica em suspensão diante de alternativas igualmente insatisfatórias, Sexto utiliza mais os verbos aporein e anarrein, cujo primeiro significado é "não ter os meios, falta de recursos", e por consequência "estar incerto, estar perplexo" e, somente em sentido derivado, estar constrangido, não saber resolver, e finalmente duvidar.

É através das traduções latinas que o senso derivado da expressão (a saber, duvidar) torna-se o sentido primário e substitui o significado original. 
É surpreendente que Paganini opere esta aproximação conceitual entre dúvida e aporia, pois anteriormente no texto havia traçado nitidamente a distinção entre ceticismo e dúvida, esclarecendo que a atitude mental do cético, caracterizada pela suspensão, não se confunde com a atitude de dúvida. No entanto, ao explicitar o estado aporético do cético, Paganini introduz a noção de incerteza, e, em sequência, aproxima a noção de dúvida ao ceticismo através do conceito de aporia. Segundo Paganini, em aporia, o cético estaria em um estado de perplexidade e de incerteza; e, em sentido derivado, estaria indeciso e, finalmente, em dúvida. Para Paganini, a dúvida pertenceria ao ceticismo em sentido secundário, derivado do sentido primário de aporia.

No entanto, se este fosse o caso, haveria uma afinidade entre ceticismo e dúvida, de modo que a introdução da dúvida no ceticismo no período moderno não constituiria uma mudança radical no significado do ceticismo, mas teria apenas operado uma alteração na ordem dos sentidos "primário" e "secundário" do estado de espírito cético, tornando um sentido secundário e derivado em sua significação principal. No entanto, como o próprio Paganini assinala, a dúvida é uma noção que foi introduzida ao ceticismo a partir do período moderno. Como veremos no quarto capítulo (pp.104-109), talvez seja devido à esta compreensão da dúvida como um sentido secundário e derivado do conceito de aporia que Paganini parece entender a introdução da dúvida no ceticismo como uma questão meramente lexical, em vez de um processo de resignificação do ceticismo, que se situa em um amplo contexto histórico de profundas transformações culturais e filosóficas. De modo similar a Paganini, R. G. Bury (1933) afirma em sua introdução às Hipotiposes de Sexto Empírico:

Um "Cético", no sentido original do termo grego, é simplesmente um investigador. Mas a investigação com frequência leva a um impasse, e termina com a incredulidade ou o desespero por uma solução, de modo que o investigador tornase "alguém que dúvida" ou um "incrédulo" e, dessa forma, recebe o ceticismo a sua conotação usual. (Bury, 1933, introdução, xxix). 
Como diz respeito à investigação de um conflito filosófico, o cético precisa investigar ambas as teses em conflito, o que, é claro, exige que considere e compreenda cada uma em particular, e, como visa aferir o peso de cada uma das partes em matéria de persuasão, precisa analisá-las lado a lado e compará-las entre si. No entanto, analisar um conflito não significa que o cético necessariamente oscile o seu juízo entre ambas as partes. Analisar lado a lado as teses do conflito, pesar os seus prós e contras é uma etapa integrante da investigação operada pelo cético, em que há nenhuma indicação de que ocorra qualquer hesitação, oscilação ou indecisão por parte do investigador.

Como notamos mais acima, na descrição de Sexto Empírico o início do filosofar do cético é equivalente à descrição clássica do início do filosofar: devese ao assombro do pensamento (thaumazein) com a dificuldade de alguma questão, sendo isto o que impele o filósofo para a investigação ${ }^{30}$. Em Sexto, a investigação filosófica (skepsis) é dirigida pelo espanto com as coisas; pela perturbação diante da anomalia e discrepância que nelas se pode encontrar. Portanto, nota-se como o início do filosofar para o cético é equivalente à descrição comum do início do filosofar que se encontra na filosofia antiga clássica ${ }^{31}$. Nas palavras de Hannah Arendt (2008, p. 286):

Na filosofia e no pensamento modernos, a dúvida ocupa a mesma posição central que, em todos os séculos anteriores, cabia ao thaumazein dos gregos, o assombro diante de tudo o que é como é. Descartes foi o primeiro a conceitualizar esta forma moderna de duvidar, que depois dele passou a ser o motor evidente e inaudível que vem movendo todo o pensamento, o eixo invisível em torno do qual todo pensamento tem girado. Tal como, desde Platão e Aristóteles até a era moderna, a filosofia conceitual, em seus maiores e mais autênticos representantes, havia sido a expressão do assombro, também a filosofia moderna, desde Descartes, tem consistido na manifestação e nas ramificações da dúvida.

30 Ver Platão, Teeteto 155 b3 e Aristóteles, Metafísica 982 b12-13.

31 Sobre a semelhança de entendimento da aporia no ceticismo pirrônico e em Aristóteles, ver LONG, 1996. 
De modo similar, Susanne langer (1929) considera que o ponto de mutação se encontre em Descartes, destacando que a dúvida não desempenha este papel no pensamento grego ou escolástico. No entanto, pode-se ver que a introdução da dúvida no origem do filosofar ocorre em relação ao ceticismo antigo já na ocasião da sua redescoberta a partir da primeira metade do século $\mathrm{XV}$, releitura que é plenamente desenvolvida por Montaigne (ver Cap. 6).

Nota-se que a substituição moderna da dúvida pelo thaumazein pode ser entendida em conexão com a aporia, na medida em que se pode entender que este conceito desempenha uma função central no modo específico de espantar-se que é característico do filosofar. Ou seja, é possível que o thaumazein que está na origem do filosofar tenha uma conexão direta ao aporein. Segundo Oliver Ranner ${ }^{32}$, o modo específico do thaumazein, que está na origem do filosofar, seria o espanto derivado de estar em aporia. De acordo com esta possibilidade, não seria o espanto pensado genericamente que levaria ao filosofar, mas sim o espanto causado pelo pensamento de encontrar-se em estado aporético, ou seja, seria mais precisamente o sentimento de não ser possível decidir entre duas opções contraditórias que fustigaria a investigação filosófica. Neste sentido, a aporia levaria ao espanto, assombro e admiração, tendo como resultado o interesse pela investigação filosófica. Aristóteles descreve a mesma origem para o filosofar:

De fato, os homens começaram a filosofar, agora como na origem, por causa da admiração, na medida em que, inicialmente, ficavam perplexos diante das dificuldades mais simples; em seguida, progredindo pouco a pouco, chegaram a enfrentar problemas sempre maiores, por exemplo, os problemas relativos aos fenômenos da lua e aos do sol e dos astros, ou os problemas relativos à geração de todo o universo. Ora, quem experimenta uma sensação de dúvida e de admiração (diaporountes) reconhece que não sabe; e é por isso que também aquele que ama o mito é, de certo modo, filósofo: o mito, com efeito, é constituído por um conjunto de coisas admiráveis. De modo que, se os homens filosofaram para libertar-se da ignorância, é evidente que buscavam o conhecimento unicamente em vista do saber, e não por alguma utilidade prática. (Metafísica, 982b11-22)

32 Ver Ranner, 2003. 
Na Metafísica, Aristóteles faz ainda uso da aporia como um método investigativo para a filosofia. A filosofia deve começar através da medição da dificuldade dos problemas, pois "quem ignora um nó não é capaz de desatá-lo" (Met. III, 995a 25-35):

De fato, quando estamos em aporia (dianoias aporia), estamos numa condição semelhante a quem está amarrado: em ambos os casos, é impossível ir adiante. Por isso, é preciso que, primeiro, sejam examinadas todas as dificuldades tanto por essas razões, como porque os que pesquisam sem primeiro ter examinado as dificuldades assemelham-se aos que não sabem aonde devem ir. Ademais, estes não são capazes de saber se encontraram ou não o que buscam, pois não lhes é claro o fim que devem alcançar, enquanto isso é claro para quem antes compreendeu as dificuldades. Ademais, quem ouviu as razões opostas, como num processo, está necessariamente em melhor condição de julgar.

Aristóteles faz uso da aporia como método investigativo. Somente ao se examinar as dificuldades de um problema seria possível achar um caminho para solucioná-las. Neste caso, a aporia situa-se no início da investigação filosófica, podendo ser considerada uma propedêutica necessária para o seu sucesso. Aristóteles prossegue no Livro Beta da Metafísica a listar quinze aporias que se pode encontrar na história da filosofia para proceder a investigá-las. As questões que analisa se mostram historicamente em aporia, ou seja, sem solução. Todo o seu esforço subsequente será no sentido de encontrar meios ou novos recursos para solucioná-las. Portanto, nota-se que o termo aporia possui um uso na filosofia anterior ao seu entrelaçamento ao ceticismo, sendo utilizado já por filósofos pré-socráticos, e sendo significativamente elaborado em conexão com a atividade do filosofar no período clássico. Em Platão e Aristóteles, a aporia - e não a dúvida - está diretamente relacionada à gênese do filosofar, sendo utilizada por Aristóteles ainda como uma etapa propedêutica, porém fundamental do método investigativo de questões filosóficas ${ }^{33}$.

33 Ver a este respeito Long, 2006. 
Uma tradução simples para aporia é “impasse”, literalmente, significa estar sem caminho, indicando uma "dificuldade de passagem". O termo designa uma situação em que se está diante de um obstáculo que não permite passagem, não há um caminho possível para seguir adiante. Diz-se, por exemplo, que os primeiros diálogos de Platão são aporéticos, pois terminam sem solução, não avançando uma tese conclusiva sobre o tema em questão. Neste sentido, o verbo aporein significa estar sem meios ou sem recursos para se efetuar a passagem à verdade. Ao se deparar com uma aporia, não se é capaz de resolver a dificuldade encontrada; não se dispõe de meios ou recursos para solucioná-la.

Aporia é um termo anterior à filosofia pirrônica, que é utilizado com frequência pela filosofia grega clássica. No Menon de Platão pode-se entender o próprio elenchus socrático como a produção de um estado aporético em seu interlocutor. Respondendo às queixas de Menon de ter sido levado a um estado aporético a respeito da virtude, tema sobre o qual antes era eloquente, Sócrates utiliza o escravo como exemplo para tentar mostrar a Menon que o estado aporético seria, na verdade, algo benéfico, na medida em que leva à investigação e à busca de uma solução para o problema ${ }^{34}$.

Nesta medida, nota-se que duvidar torna-se propriamente o modelo da filosofia moderna. A expressão "A filosofia começa pela dúvida" demonstra o novo entendimento de que a dúvida estaria na origem da filosofia e do filosofar, ocupando o lugar desempenhado pelo thaumazein na filosofia clássica. A dúvida viria inclusive a ser capaz de capturar a "essência" do filósofo moderno: "É preciso duvidar de tudo" 35 passa a ser a sua máxima, sendo o filósofo aquele que duvida de tudo - a dúvida viria a assinalar a radicalidade da filosofia, da atividade do filosofar.

34 Ver Kahn (1996, cap. 3).

35 Ambas expressões tornam-se populares a partir do cartesianismo. Ver a este respeito Mehl, 2001, e o interessante relato de Kierkegaard do espanto de Johannes Climacus diante de tais expressões em É preciso duvidar de tudo (2003). 
Desta maneira, é possível entender a introdução da dúvida no ceticismo no período do Renascimento como um caso ilustrativo no início do período moderno do processo que concederia este papel central que a dúvida viria a desempenhar para a filosofia em geral na consciência moderna. Até os dias atuais, intérpretes como Arne Naess, Michael Williams, e Ezequiel de Olaso, em meio às suas tentativas de distinguir entre ceticismo e dúvida, mantêm este papel fundamental que é conferido à dúvida. Como estaria no início do filosofar, ser cético ou dogmático diria respeito a diferentes atitudes em relação à dúvida, e diferentes modos de se "lidar" com a dúvida e de "solucioná-la".

Buscaremos mostrar que a noção de dúvida não está presente, nem mesmo implicitamente, em nenhuma das etapas do procedimento cético na descrição de Sexto. A introdução da dúvida na modernidade pode ser considerada uma inovação no modo de se compreender o ceticismo (e de se conceber a filosofia em geral), que não encontra elementos textuais em Sexto Empírico, direta ou indiretamente.

Portanto, nosso objetivo é manter, ao contrário dos intérpretes contemporâneos aqui discutidos, que dúvida e ceticismo em princípio não têm nenhuma afinidade entre $\mathrm{si}^{36}$. Para tanto, cabe examinar principalmente se o termos técnicos aporia e epoche seriam de algum modo semelhantes à dúvida, e semelhantes a tal ponto de poderem ser tomados como conceitos equivalentes, intercambiáveis. Para fazê-lo, primeiramente analisaremos o próprio conceito de dúvida em sua polissemia, de modo a pensar de que maneira se poderia cotejar esta noção com o ceticismo.

\footnotetext{
${ }^{36}$ Para pensá-los desta forma, foi preciso operar diversas transformações conceituais, as quais ocorrem historicamente (ver Cap. 5).
} 
3.2

Os significados da Dúvida

Há diversos modos de se entender a dúvida. O próprio termo possui várias acepções e pode assinalar uma ampla gama de diferentes fenômenos. Além desta polissemia encontrada no uso comum da noção de dúvida, há ainda os que lhe são acrescentados pelo pensamento filosófico (o que pode ocorrer de diversas maneiras). Cabe agora buscar uma compreensão clara do significado da dúvida, para em seguida compará-la com o ceticismo pirrônico. Sem se pretender à exaustão, podem-se distinguir quatro sentidos principais da noção de dúvida em seu uso na linguagem comum: 1) ter uma dúvida; 2) levantar uma dúvida; 3) duvidar de algo; e 4) estar em dúvida.

1) Um uso bastante comum do termo dúvida é enquanto forma de questionamento ou inquirição. Este sentido de duvidar é mais comumente expresso na forma "x tem uma dúvida sobre p", como um aluno que tem uma questão (sobre um problema matemático, um conceito de geografia política, etc.) afirma "ter uma dúvida". Neste sentido, o seu significado parece ser simplesmente o de "ter uma questão", indagar-se sobre algo: quando não se sabe de algo, para descobrir e tirar a sua dúvida deve-se pesquisar, perguntar, investigar. Nota-se a ligação deste uso do termo à noção de ignorância: tem-se uma dúvida quando não se conhece algo. "Ter uma dúvida sobre p" parece ser apenas um modo de dizer que se tem uma questão a respeito de p que se deseja esclarecer. Este uso do termo parece ser apenas Esta questão, no entanto, pode se dar na forma de uma dúvida propriamente. Se aquilo sobre o que se tem dúvida apresenta-se não na forma de uma simples interrogação, como uma questão em aberto (Qual é a capital da Bulgária?), mas na forma de alternativas (Qual é a capital da Suíça, Berna ou Genebra?), aproxima-se então ao sentido próprio da noção de dúvida. 
2) No sentido de "levantar uma dúvida a respeito de p", a dúvida está relacionada à ideia de objeção. Pode-se entender que "levantar", "colocar" ou "lançar" dúvidas a respeito de $\mathrm{p}$ significa que se tem reservas a respeito de $\mathrm{p}$, ou que se poderia ter objeções contra p. É deste modo que Kant explora este sentido de dúvida, em conexão à distinção entre dúvida subjetiva e dúvida objetiva:

A dúvida é uma razão contrária ou um mero obstáculo do assentimento, que pode ser considerada quer subjetiva quer objetivamente. Subjetivamente, ela é às vezes considerada como o estado de uma mente indecisa, e objetivamente como o conhecimento da insuficiência das razões para o assentimento. Neste último sentido, ela se chama objeção, isto é, uma razão objetiva para se ter por falso um conhecimento tido por verdadeiro. (Kant, 2011,Introdução, X, p. 99; Lógica Jasche, A 129, Ak 83)

Para Kant, uma dúvida objetiva parece constituir uma forma de conhecimento; pois, quando se tem uma dúvida objetiva a respeito de $\mathrm{p}$, sabe-se de modo claro e bem determinado a "insuficiência das razões para o assentimento", ou seja, são conhecidas as razões contrárias e os obstáculos ao assentimento a p. Mas, se as razões contrárias estiverem fundadas "apenas na inclinação, hábito, e coisas semelhantes", sem se saber se realmente pertencem ao objeto ou se são válidas apenas subjetivamente, esta é uma dúvida subjetiva ou “escrúpulos". Sente-se em dúvida a respeito de p, mas não se podem indicar claramente quais as dificuldades em p que causam reservas a seu respeito:

A gente duvida sem que possa se explicar de maneira clara e determinada sobre a razão de duvidar e sem que possa discernir se esta razão está no objeto ele próprio ou apenas no sujeito. Ora, se esses escrúpulos devem poder ser afastados, eles têm que ser levados à clareza e determinidade de uma objeção (op. Cit, p. 100).

Desta forma, levantar uma dúvida sobre p seria uma maneira mais fraca de levantar objeções contra p. Enquanto não se é capaz de determinar a causa da dúvida, as razões para duvidar, não é possível formular uma objeção bem definida, restando apenas "escrúpulos". Ou seja, não se pode veicular com 
determinação uma reserva em relação a $\mathrm{p}$, nem se pode pretender ser capaz de defendê-la contra argumentos contrários, pois não se conhece suficientemente bem as próprias razões para tal reserva. Por isso, segundo Kant "é modéstia apresentar suas objeções como dúvidas apenas".

3) O significado de "duvidar de algo", que poderia ser expresso como " $x$ duvida de que p", é semelhante à desconfiança ou incredulidade em relação a uma determinada situação ou proposição. Na frase "duvido que chova amanhã", indica-se uma tendência a julgar que não choverá amanhã. Portanto, nesta acepção, duvidar de que $\mathrm{p}$ consiste em desconfiar ou descrer que p. Como assinala Lorenzo Corti, este uso da dúvida assinala, mais especificamente, a tendência a julgar que $\sim$ p. Portanto, no mais das vezes, a frase "duvido que chova" significa que se está inclinado a crer que não irá chover. No exemplo de Corti (2012, p.55):

Ora, é verdade que duvidar de que p pode implicar a inclinação para fazer um julgamento. (...) Consideremos o seguinte diálogo. Eu pergunto a meu irmão: "Massa vai ganhar o campeonato de formula 1 este ano?" Ele me responde: "No começo da temporada, eu não tinha nenhuma ideia sobre isso, mas, depois de seus últimos fracassos, duvido que ele consiga ser campeão" ou "No começo da temporada, eu duvidava que ele pudesse ganhar, mas agora, após seus últimos triunfos, não tenho mais nenhuma ideia sobre isso". "Duvidar de que p", nessas frases, implica estar inclinado a julgar e a crer que $\sim p$. Para ser mais preciso, "duvidar de que p", nesse uso, significa (...) estar inclinado a crer que $\sim$ p.

Desta maneira, a dúvida como tendência à descrença pode ser entendida como a tendência à negação de uma determinada proposição. Pode-se entender este sentido de dúvida como uma "negação ativa" ${ }^{38}$ : manifesta a tendência a julgar ou o juízo de que não há um determinado conhecimento, ou ainda, de que não há conhecimento de um modo geral - o que comumente se encontra no período moderno -: o ceticismo seria a doutrina que afirma não ser o homem capaz de obter conhecimento certo, seguro, inabalável.

\footnotetext{
${ }^{38}$ Agradeço a Rogério Soares da Costa por chamar a atenção para os desdobramentos deste sentido de dúvida.
} 
Neste sentido, ter uma dúvida pode significar, na verdade, manter que não há conhecimento de tal ordem; manter ativamente determinadas negações. Notase que este modo de se entender a dúvida assemelha-se àquilo que Sexto Empírico descreve como "dogmatismo negativo". Afirmar que o cético duvidaria neste sentido, assemelha-se, portanto, à crítica de que o ceticismo teria, na verdade, um componente dogmático em seu próprio seio, de acordo com o qual tenderia a uma negação. Nota-se que a questão de se haveria uma tendência dogmática no conceito do ceticismo é levantada desde a Antiguidade, sendo por vezes formulada através da inconsistência entre a skepsis e a epoche. Nas palavras de Bicca, "[...] a acusação haver um componente dogmático ou doutrinário no ceticismo: o cético sabe que é impossível o conhecimento e, portanto, já espera que a epoche será eficaz - e, ainda, se sabe que será eficaz antes de toda e qualquer investigação, então por que investiga? (2012, p.178)’”. Não obstante, é problemática a consideração de que esta tendência dogmática se assemelharia ao conceito de dúvida. Quem afirma "duvido da possibilidade de todo e qualquer conhecimento suprassensível" não está realmente em dúvida; pois "duvidar" do conhecimento suprassensível, nesse caso, expressa na verdade a crença de que tal conhecimento não exista ou não seja possível, sendo uma simples negação (ou expressa a tendência a julgar que não há conhecimento suprassensível; uma forma mais fraca de afirmar a mesma descrença, não como convicção, mas como suspeita, inclinação, desconfiança). Deste modo, neste sentido de negação ativa, pode-se considerar que "ter uma dúvida" na verdade não é a manifestação de uma dúvida propriamente, mas de uma crença. Enquanto negação ou tendência à negação, "duvidar de p" significaria apenas "descrer que p". Deste modo, esta acepção de cúdiva, tão frequentemente identificada com o ceticismo no período moderno, poderia ser considerada um uso catacrético da noção de dúvida, que não expressa as características essenciais do conceito de dúvida, mas assemelha-se mais à crença, ou à descrença do que à dúvida propriamente. Embora Sexto Empírico considere esta forma de postura intelectual um "dogmatismo negativo" que no início das hipotiposes denomina de filosofia acadêmica -, como veremos nos capítulos seguintes esta acepção de dúvida é constantemente enfatizada no 
período moderno, sendo com ela que mais frequentemente se confunde o ceticismo: a negação do conhecimento é simplesmente tomada como uma atititude ou postura cética.

4) "Estar em dúvida" sobre algo indica propriamente um estado mental, que pode ser descrito como um estado de oscilação entre duas ou mais alternativas, resultando em uma vacilação para decidir. Pode-se considerar esta acepção de dúvida, a dúvida enquanto estado mental, como o significado primário da noção de dúvida, ao passo que as acepções discutidas acima diriam respeito a sentidos secundários ou catacréticos da noção de dúvida. Na medida em que as expressões "duvidar de algo", "ter uma dúvida", e "levantar uma dúvida" podem ser aproximadas, respectivamente, aos sentidos de descrença, inquirição e de objeção, estas expressões não parecem assinalar o fenômeno específico designado pela noção de dúvida. Em dúvida, a mente ou a consciência encontra-se em um estado de hesitação, pois vacila e oscila entre as alternativas, sem conseguir decidir entre elas. A inquietação, e possivelmente a irritação que estão atreladas ao estado de dúvida remetem a esta característica. Sem este movimento da consciência de oscilação entre alternativas, de vacilar entre um e outro lado e não conseguir decidir-se, não é possível compreender a dúvida enquanto estado mental.

Para Kierkegaard, a dúvida é propriamente um estado da consciência. A consciência é o terceiro termo sem o qual as duas alternativas em conflito não se sustentam $^{39}$. Toda dúvida é uma dúvida para uma consciência. Neste sentido, a dúvida é a relação da consciência com alternativas dentre as quais não é capaz ou não se sente em condições de optar. Portanto, a existência da dúvida depende da permanência das alternativas em conflito para uma consciência. Enquanto há dúvida, ou enquanto se está em dúvida, o conflito está presente, resistindo a uma resolução. Ou seja, o horizonte da consciência em um estado de dúvida são as próprias alternativas em conflito.

39 Cf. Kierkegaard, 2003. 
Deste modo, o estado de dúvida é um estado mental caracterizado propriamente pelo conflito entre alternativas. Se as alternativas não mais se apresentarem, ou se desaparecer a dificuldade de escolher entre elas, não há mais a dúvida. Portanto, um elemento essencial da dúvida enquanto estado mental é um obstáculo ou dificuldade na escolha entre alternativas conflitantes. Neste sentido, estar em dúvida entre "que p e que $\sim p$ " consiste em um estado de dificuldade de escolher entre alternativas em conflito. Para haver a dúvida enquanto um estado mental, que é descritivo de um movimento de oscilação da consciência, não pode haver distanciamento das alternativas em conflito: a dúvida é estar entre as alternativas. Quando se está em dúvida, ou enquanto se está em um estado de dúvida, estão necessariamente presentes as alternativas conflitantes, pois são estas que caracterizam a dúvida e são elas que constituem o estado de dúvida enquanto estado mental. No entanto, após distingui-lo da acepção de "duvidar de algo", que se confunde com descrença ou tendência a não crer que $x$, Corti caracteriza o "estado de dúvida" da seguinte maneira:

[...] está claro que existe um sentido de "duvidar de que p" que não implica estar inclinado a crer, ou a julgar que $\sim$ p. Consideremos o seguinte diálogo: "Você acredita que Massa vai ganhar este ano?"; "Para dizer a verdade, não [sei nem] se ele vai ganhar, nem se não vai ganhar. Estou em dúvida". Noutros termos, estar num estado de dúvida sobre p pode querer dizer simplesmente não crer que $\mathrm{p}$, nem que $\sim$ p. (Corti, 2012, p.55)

Para Corti, como estar em dúvida a respeito de p seria não crer que p e não crer que $\sim p$, "[...] o estado de dúvida é um estado de não crença" (p. 60). No entanto, o estado de dúvida não pode ser caracterizado como um estado de "não crença". Estar em dúvida indica outro fenômeno mental, outro estado da consciência, que não pode ser confundido simplesmente com a descrença. Sendo um estado de hesitação, de oscilação, a dúvida não é um estado de não crença em p e não crença em p. A dúvida indica, na verdade, um estado de oscilação entre a crença e a descrença (se se quiser relacionar a dúvida à crença, o que não parece 
ser necessário). A dúvida distingue-se tanto de um estado de crença quanto de um estado de não crença.

Enquanto um estado mental, a dúvida não é estática como a definição de Corti levaria a entender. Pelo contrário, o estado de dúvida pode ser considerado um estado dinâmico, de oscilação entre as alternativas possíveis, caracterizandose principalmente pela vacilação e hesitação por ele provocadas. Em dúvida, a consciência movimenta-se entre as alternativas, oscila e "balança" entre uma e outra, contudo sem ser capaz de decidir-se. O único resultado que é constante enquanto se está em dúvida é a indecisão. Inclusive, nada parece haver de fixo e estável na dúvida que possibilitariam caracterizá-la propriamente como um estado, exceto o seu "movimento pendulatório": deste modo, pode-se descrevê-la como um estado dinâmico da consciência.

Deste modo, é preciso cautela em se considerar o estado de dúvida como um estado de não crença. A dúvida não é equivalente nem à crença, nem à descrença. Como a dúvida é um estado em que a consciência analisa as alternativas sem ser capaz de decidir entre elas, é propriamente um estado de oscilação da consciência, em que esta permanece entre a crença e a não crença. Logo, o estado de dúvida ocorre somente quando " $\mathrm{x}$ " - que é uma consciência - oscila entre p e p na tentativa de chegar a uma decisão.

E, como a dúvida consiste na relação entre uma consciência e alternativas, a tendência ou o impulso a julgar e a decidir pode ser considerado a segunda condição necessária para que se possa caracterizar a dúvida como um estado mental. Pois no estado de dúvida há uma tendência a julgar ou a decidir, sem a qual não é concebível a hesitação, vacilação e oscilação entre as alternativas que lhe são constitutivas. Entende-se este impulso a julgar como a tendência a emitir um juízo, a chegar a uma tomada de decisão. Desta maneira, o que confere sentido à hesitação do estado de dúvida é a própria vontade de julgar diante de um obstáculo para a sua realização, podendo ser considerado o seu objetivo final uma tomada de decisão, a emissão de um juízo, a obtenção de uma crença, etc. Peirce parece se referir a este impulso a julgar subjacente à dúvida quando afirma: 
A irritação da dúvida causa uma luta para atingir um estado de crença. Chamarei a esta luta inquirição, embora deva admitir-se que esta não é, às vezes, a designação mais adequada. A irritação da dúvida é o único motivo imediato para a luta por atingir a crença. (Peirce, 1877)

Para Peirce, a "irritação da dúvida" é o que fustiga a inquirição. Embora esta não seja a única forma de se entender a dúvida, ou o único modo de se pensar a motivação por trás da inquirição, Peirce chama a atenção para o impulso a julgar que é subjacente ao estado de dúvida: "A dúvida é um estado de desconforto e insatisfação do qual lutamos para nos libertar e passar ao estado de crença". Em um estado de dúvida, a oscilação da consciência se dá na tentativa de atingir uma crença - sem a busca para se atingir uma crença não é possível compreender o movimento da consciência de oscilação e hesitação entre as alternativas, ou a “irritação da dúvida”.

Nota-se que não se pode explicar o dinamismo da dúvida sem o "impulso a julgar" - ou, nas palavras de Peirce, a "luta por atingir uma crença": a oscilação da consciência é o resultado do obstáculo à sua motivação de escolher entre as alternativas, de afirmar ou negar um juízo, de aceitar ou rejeitar uma crença. Deste modo, o estado de dúvida pode ser considerado como um estado filiado ao dogmatismo, na medida em que a consciência está comprometida com as alternativas em conflito; com a escolha entre elas. Nas palavras de Olaso (1975, p. 33), “duvidar é próprio de quem crê poder emitir um juízo”. É constitutivo do estado de dúvida o impulso a emitir um juízo, a "atingir" uma crença - ao mesmo tempo em que, devido a algum obstáculo que se impõe não se é capaz de fazê-lo. Enquanto se está em dúvida, as alternativas persistem como o horizonte em que a consciência transita e, caso seja resolvida a dificuldade, dissipa-se o conflito entre as alternativas, e, com isso, dissolve-se o próprio estado de dúvida - tanto quanto, ausente o impulso a julgar, não há dúvida.

Portanto, pode-se considerar que haja um dogmatismo subjacente ao estado de dúvida de um modo essencial. Hesita-se entre as alternativas, não se consegue 
decidir, mas, devido a alguma necessidade, seja ela imposta externamente, seja advinda da vontade, é preciso ainda decidir. Deste modo, pode-se dizer que a dúvida é uma expressão do próprio dogmatismo quando, diante de algum obstáculo, o processo de deliberação encontra-se em dificuldade, o assentimento vacila, porém, permanece fixa a necessidade ou o desejo de conferir o assentimento à matéria em questão. Neste sentido, o estado de dúvida pode ser considerado como um estado mental em relação de continuidade e estreita conexão com o dogmatismo. Segundo Naess (1968, apud Bicca, 2014):

[...] não há nenhuma base, na descrição que faz Sexto, para representar-se o cético maduro como uma pessoa que mostra indeterminação, irresolução, indecisão, vacilação, hesitação, suspense, perplexidade, atordoamento, embaraço, confusão, desorientação, descrença, incredulidade, desconfiança, acanhamento ou suspeita, como quer que esses termos caibam para descrever seu estado mental quando ele se põe a escutar dogmáticos. Não há nada a sugerir que o cético, enquanto uma pessoa real, devesse sentir-se obrigado a sair por aí duvidando ou buscando mais que os outros. Aliás, a ânsia de duvidar e buscar aplicar-se-ia mais ao dogmático, pois quanto mais se postula como verdadeiro e quanto mais enredado alguém se acha na intelectualização de atitudes, tanto mais há para se duvidar. Abstendo-se de dogmatizar, uma pessoa pode reduzir as ocasiões para duvidar.

Neste sentido, pode-se dizer que a dúvida não assinala uma ruptura radical com o dogmatismo, com a crença ou com o assentimento. Pelo contrário, na medida em que o estado de dúvida se caracteriza pela tendência ou impulso a julgar, pode-se afirmar que há uma relação de parentesco entre dúvida e dogmatismo. O ato de duvidar e "estar em dúvida" podem ser considerada realidade mais próximas do dogmático que do cético. A dúvida pode assinalar uma pausa no dogmatismo, um estado em que o dogmatismo encontra um bloqueio. E, neste sentido, não rompe, cessa, ou opõe-se necessariamente ao dogmatismo, mas, pelo contrário, está atrelado a ele. A dúvida é gerada e surge no interior de um contexto dogmático.

Portanto, a dúvida é um estado mental de indecisão, no qual, diante de alternativas em conflito, uma consciência oscila e hesita entre as alternativas, sendo esta oscilação devida ao impulso de se resolver um conflito e se chegar a 
uma decisão. Logo, podem-se destacar algumas características principais da dúvida enquanto estado mental:

1) Nasce por conta de algum obstáculo ou dificuldade para se decidir entre duas ou mais alternativas;

2) É um estado mental dinâmico, em que a consciência oscila entre as alternativas possíveis; "estar entre" alternativas constitui o horizonte da consciência em um estado de dúvida;

3) O impulso a julgar e a decidir constitui a força subjacente à dúvida, que lança a consciência em seu movimento pendulatório entre as alternativas possíveis.

Tendo em vista estas características, nota-se que se costuma descrever o estado de dúvida como um fenômeno mental associado à 1) hesitação, vacilação, oscilação, indecisão, irresolução - pois "estar entre" é a situação em que se encontra uma consciência em dúvida, bem como à 2) inconstância, perturbação, irritação, frustração e até medo, pois a consciência deseja decidir entre as alternativas embora, em dúvida, não seja capaz de fazê-lo. 
3.3

Dúvida vs. Ceticismo

Tendo em vista as conclusões da seção anterior, procedemos em seguida à comparação entre a noção de dúvida e o ceticismo. Como a acepção de "estar em dúvida" pode ser considerada capturar o significado essencial da noção, é especialmente esta acepção que será agora comparada ao ceticismo e seus termos técnicos principais. Como veremos nos capítulos seguintes, as transformações do ceticismo no período moderno ocorrem principalmente através da introdução da noção de dúvida nas etapas da diaphonia, aporia e epoche do procedimento cético - ou através da substituição de uma ou mais destas etapas pela dúvida. A seguir, buscamos examinar cada um destes elementos ou etapas da skeptike agoge com algumas das principais características da noção de dúvida que examinamos acima.

Por que o cético estaria "em desespero por uma solução", ou teria o problema de não "saber resolver", como sugerem Bury e Paganini? Como vimos, a característica específica que define o cético é a habilidade de oposição. Sexto escreve em HP I, 12 que "a principal origem do ceticismo é a prática de opor a cada afirmação uma afirmação equivalente; parece-nos que fazer isto coloca um fim ao dogmatismo". Pode-se afirmar que o cético não está "em desespero por uma solução", pois não é uma solução (dogmática) o que busca em sua investigação. O que caracteriza uma aporia é o fato de não ser decidível, não haver caminhos para ultrapassar a dificuldade que se apresenta. Estar diante de uma aporia pode ser considerado a origem do ceticismo, e produzir uma aporia indica o uso bem sucedido da habilidade cética, ao contrário de uma "falta de recursos".

Em sua investigação, o cético é capaz de analisar e pesar os argumentos a favor de p, e então, encontrar, escolher ou produzir cuidadosamente argumentos 
de igual peso igual a favor de $\sim$ p. O cético o faz com o propósito de produzir a aporia $^{40}$. Esta é a sua habilidade, sendo igualmente a característica da sua investigação, o caráter da skepsis. O cético não é um investigador que se supõe passivo ou imparcial ${ }^{41}$, mas em sua investigação pratica o ceticismo, i.e., busca exercitar a sua habilidade de oposição de modo a evitar o dogmatismo.

Segundo Pierre Pellegrin (1997, p.41): “estar em uma aporia é estar em um embaraço e em uma perplexidade que interditam toda decisão". Deve-se notar que a aporia pode causar perplexidade - tanto quanto pode causar espanto, indignação, assombro, admiração -, mas nao é sinônimo de perplexidade. No caso do cético, a aporia é o que o leva à suspensão. Em HP I, 31 lê-se: "Falando-se de um modo geral, pode-se dizer que [a epoche] advém através da oposição das coisas".

Ao examinar o conflito e constatá-lo ser aporético, o investigador cético sente-se incapaz de decidi-lo. Devido à ausência de critérios para se resolver o conflito, o cético não oscila entre as alternativas, não hesita ou está indeciso. Quando um exame foi realizado, e o seu resultado é um impasse, restando apenas o sentimento de que não se pode decidi-lo. Ao examinar um conflito e se constatar a equipolência entre as suas partes, e a ausencia de um critério de resolução, uma aporia é estabelecida; diante da qual nenhuma decisão é possível. Deste modo, o cético não está indeciso diante do conflito, mas é o próprio conflito que se mostra ser indecidivel. A investigação cética mostra que a disputa em questão é anepikritos, indecidível (HP I 98, 112, 165, etc.) Impasse é o sentido próprio da aporia na investigação cética: uma disputa em que não há caminho possível a se seguir, por conta de se ter mostrado ser ela mesma indecidível.

Logo, para o cético, a aporia resulta de uma investigação cuidadosa, mostrando ser impossível qualquer decisão. Deve-se observar que há algo em comum à aporia e à dúvida: ambas envolvem duas ou mais alternativas (um

40 Cf. $H P$ III, 228, em que Sexto explica por que o cético, às vezes, faz uso propositadamente de argumentos fracos e pouco convincentes.

41 Como sugere Bolzani (1996). 
conflito que requer deliberação), e possuem alguma dificuldade ou obstáculo em sua origem. Contudo, a dúvida nasce de um obstáculo que torna difícil uma decisão, levando à oscilação entre alternativas, ao passo que a aporia apresenta-se como um obstáculo intransponível, através do qual não há passagem possível; é indecidivel, um impasse. Para haver aporia, é necessário que se mostre a ausência de meios de decidir: o cético exibe um conflito entre alternativas opostas e excludentes de igual peso em matéria de persuasão.

Portanto, a aporia não é equivalente e não se confunde com a dúvida no que diz respeito à indecisão: diante de uma aporia, não se está indeciso, pois qualquer decisão racional está interditada, sendo o conflito indecidível, ao passo que a dúvida se caracteriza como um estado de indecisão. Em aporia, a dificuldade percebida pelo cético gera o sentimento de não haver possibilidade de decisão. Pelo contrário, pode-se afirmar que o conflito que caracteriza o estado de dúvida é um conflito em aberto, pois a dúvida não significa que a verdade não possa ser encontrada em uma das alternativas. Ou seja, quando se está em dúvida, não necessariamente sente-se que a matéria em questão seria indecidível. Pelo contrário, como o estado de dúvida se caracteriza justamente por estar entre alternativas, hesitar entre possíveis decisões, parece estranha a consideração de que o objeto da dúvida seria indecidível (embora seja possível).

Quando se está em dúvida, sente-se uma dificuldade para decidir, mas não necessariamente é impossível uma decisão. Como vimos acima, a dúvida não se caracteriza por uma incapacidade de decisão, mas, pelo contrário, entende-se a dúvida um estado de indecisão: o assentimento vacila, oscila entre ambos os lados, pois não se sabe qual se deve preferir. E nota-se que há uma diferença notável entre um estado de indecisão e a incapacidade de decisão. Quando se está indeciso, tem-se em vista a tomada de uma decisão, contudo, não se sabe ao certo como fazê-lo. A indecisão só faz sentido dentro do horizonte de uma tomada de decisão. A incapacidade de decisão, pelo contrário, suspende ou impossibilita uma tomada de decisão. 
No início das Hipotiposes (HP I, 10), Sexto caracteriza a epoche da seguinte maneira: "A suspensão é um estado de repouso mental (stasis dianoias), de acordo com o qual não afirmamos nem negamos nada". Neste sentido, a suspensão caracteriza-se como um movimento de sustar, cessar, interromper o intelecto diante da aporia que se apresenta. Devido à constatação de não ser possível resolver o impasse entre os argumentos dogmáticos em conflito, ou não ser possível decidir-se a favor de uma ou outra tese investigada, Sexto Empírico descreve que o cético é levado à suspensão. Portanto, o cético não é levado à suspensão porque está em dúvida entre as alternativas em conflito, o seu juízo não oscila por conta de averiguar uma aporia, e tampouco está indeciso no momento em que a suspensão ocorre. O cético suspende-se devido ao impasse em que se encontram as alternativas em conflito (diaphonia). O impasse (aporia) é devido à força igual existente entre os objetos e discursos opostos (isosthenia), que não possibilitam uma decisão. O cético não é capaz de dizer a qual lado do conflito deveria conferir o seu assentimento, sendo, então, levado à suspensão (HP I, 8).

Entretanto, no caso da dúvida não é nem mesmo necessário que as alternativas sejam contraditórias ou mutuamente excludentes. Como assinalam Broughton (2002) e Perrin (2008), pode-se estar em dúvida a respeito de uma única proposição, e oscilar o assentimento entre a sua afirmação e a sua negação, bem como estar em dúvida a respeito de alternativas diferentes, que, no entanto, não são necessariamente contráditórias. Neste sentido, a isosthenia não é uma condição necessária para a dúvida. Nas palavras de Perrin (2008, p.53):

Uma razão para duvidar de que pé uma razão para estar menos do que certo de que p. É possível ter uma razão para duvidar de que p e, logo, para estar menos do que certo de que $p$, e, não obstante, ter evidência suficiente da verdade de $p$ para crer que $\mathrm{p}$ e estar justificado em fazê-lo.

De acordo com Thagard (2004), a dúvida não requer alternativas contraditórias, mas sugere que o risco de diminuir a coerência de um sistema de crenças já seria uma razão suficiente para se duvidar de uma proposição. De 
acordo com esta leitura, para engendrar a dúvida, não é necessário que as alternativas sejam nem opostas, contraditórias, ou excludentes - nem a diaphonia (conflito excludente), nem a isosthenia (equipolencia) são elementos necessários ou constitutivos da noção de dúvida. Em HP I, 196, Sexto explica a frase cética epecho, "Eu suspendo":

Adotamos a frase "eu suspendo meu juízo" no lugar de "não sou capaz de dizer qual dos objetos apresentados devo achar convincente e qual não devo achar convincente", de modo a indicar que os objetos aparecem para nós de modo igual em matéria de credibilidade ou incredibilidade.

A epoche é caracterizada por uma incapacidade de dizer a qual dos objetos apresentados deve-se conceder o assentimento. Como as alternativas em conflito apresentam-se de modo igual em matéria de persuasão, não possibilitam nenhuma decisão, de modo que o cético suspende-se devido à impossibilidade de decidir ou de preferir entre impressões. Portanto, é somente quando o cético está diante de um conflito equipolente e se sente incapaz de decidir que é, então, levado à epoche. A suspensão do conflito marca o desligamento em relação a ambas as teses. Neste sentido, pode-se afirmar que o cético deliberadamente evita o dogmatismo, bem como o "impulso dogmático". O cético evita a tendência dogmática, ou o impulso a julgar, a aceitar ou rejeitar uma posição teórica sobre a realidade não evidente e vir a sustentá-la como doutrina.

Deste modo, com a epoche, o cético se recusa a proferir qualquer afirmação ou negação a respeito das alternativas conflitantes. Neste sentido, a suspensão poderia ser descrita como a suspensão tanto da crença em p, quanto da crença em $\sim$ p. Já a dúvida seria estar entre crer que p e crer que $\sim$ p. Em todo caso, a dúvida não é uma suspensão, mas é dinâmica, sendo o movimento da consciência em direção à crença, mas também à descrença, sem alcançar nenhuma delas. Em dúvida, busca-se alcançar a crença ou a descrença, de modo a resolver o problema, ao passo que a suspensão é a interrupção de tal tentativa, um cancelamento, desligamento em relação tanto à crença quanto à descrença. 
E nota-se que, quando se está em dúvida acerca de algo, ainda que se saiba tratar-se de uma situação aporética, ainda assim é possível uma tomada de decisão. Pois aqui entra em cena o impulso a julgar que subjaz à dúvida. $\mathrm{O}$ estado de dúvida supõe a vontade de decisão, ou, dependendo do contexto em que se manifesta, até mesmo impõe a necessidade de uma decisão. Este elemento volitivo que subjaz à dúvida permite que, mesmo no caso de não haver meios para se tomar uma decisão, ainda assim seja possível decidir.

Ao longo de HP I, 187-209, Sexto Empírico caracteriza o estado mental do cético como um estado de indiferença, em que não tem mais a inclinação a julgar, sendo, em consequência, indiferente ao impulso dogmático. Em HP, I, 192, ao descrever o estado cético de não asserção (aphasia), Sexto Empírico escreve:

\begin{abstract}
A respeito da não asserção o que dizemos é isto. O termo "asserção" possui dois sentidos, um geral e um estrito; usado em sentido genérico, indica afirmação ou negação, como, por exemplo, "É dia", "Não é dia"; em sentido estrito indica somente a afirmação, e neste sentido as negações não são designadas como asserções. A não asserção é, portanto, a renúncia à asserção entendida em sentido genérico, no qual dizemos que estão incluídas tanto a afirmação quanto a negação, de modo que a não asserção é uma afecção (pathos) por causa da qual recusamos tanto colocar quanto negar qualquer coisa.
\end{abstract}

Ao suspender-se diante do conflito, o estado mental em que o cético se encontra é um estado de indiferença. A epoche não é apenas o ato de suspensão do juízo, mas de suspender-se do conflito. $O$ cético está indiferente às alternativas em conflito. Com a suspensão, distancia-se de ambas as alternativas em conflito. No caso da dúvida, a consciência oscila entre as alternativas; não há distanciamento, sendo justamente isto o que ocorre com a epoche. Neste sentido, dúvida e epoche excluem-se mutuamente: não é possível estar entre alternativas e ao mesmo tempo distanciar-se delas.

Segundo Kant, o investigador cético seria um terceiro observador, que vê as alternativas em conflito se contradizer e se anularem mutuamente. "Dois filósofos metafísicos, um dos quais prova a tese, e o outro a antítese, ocupam aos olhos de 
um terceiro observador a posição de um exame cético. Devem-se fazer ambas as coisas por si mesmo" (2005, p. 205. Ak 18:61, Reflexão 5015) ${ }^{42}$. Neste sentido, o investigador cético observa o conflito entre as teses dogmáticas, mas não se confunde com elas, pois não está comprometido com nenhuma. Portanto, para o investigador cético, a aporia que examina não é necessariamente o seu conflito. Da mesma forma, a sua própria consciência não necessariamente oscila ou hesita entre as alternativas, mas opõe uma à outra alternativa e as exibe como um conflito equipolente.

Vimos que, de acordo com Kierkegaard, a consciência é o terceiro elemento que, juntamente às alternativas, compõe o estado de dúvida. Em dúvida, as alternativas constituem um conflito da consciência. É sempre uma consciência que está em dúvida e oscila, de modo que as alternativas são propriamente o horizonte da consciência em um estado de dúvida. Mas, para o cético, a aporia não consiste em um conflito da sua consciência, mas um conflito entre teses dogmáticas, e o cético se suspende de ambas as teses, i.e, do conflito como um todo. Em HP I, 190, o estado mental de indiferença é caracterizado por Sexto pelo termo arrepsia, i.e., um estado de equilíbrio. O cético suspende-se em face de uma aporia, quando não há saída da equipolência entre as alternativas. Da mesma maneira que a suspensão decorre do estado de equilíbrio entre as alternativas, este é o estado de espírito em que o cético se encontra ao suspender-se. Portanto, podese entender o estado de repouso mental (stasis dianóias) ocasionado pela epoche como um estado mental de equilíbrio. Deste modo, a suspensão caracteriza-se como um estado de equilíbrio do pensamento, em que o cético está indiferente às teses em conflito, evitando afirmar ou negar. E, pelo contrário, como vimos é constitutivo à dúvida o "impulso a julgar". Logo, podem-se resumir os pontos acima da seguinte forma:

42 Ver Skvirsky (2012). 
1) A dúvida caracteriza-se como um estado de indecisão; ao passo que o cético é levado a suspender-se por conta do impasse por ele investigado ser indecidível (anepikritos)

2) Para estar em dúvida não é necessário que as alternativas sejam nem opostas, nem mutuamente excludentes, mas estas características são fundamentais para a investigação cética, sendo a própria "habilidade específica" do cético a "capacidade de oposição";

3) As alternativas são o horizonte da consciência enquanto está em dúvida; já o cético desliga-se, suspende-se, distancia-se de ambas alternativas bem como do conflito como um todo.

4) O estado de oscilação da consciência, que descrevemos como o estado dinâmico da dúvida contrapõe-se como o estado de indiferença e equilíbrio descrito como o estado produzido pela epoche

5) O impulso a julgar constitutivo da dúvida, sendo aquilo que primeiramente explica o movimento de lançar a consciência a buscar, em face de obstáculos, uma tomada de decisão, contradiz-se à atitude própria do cético de recusar-se a afirmar e a negar algo acerca de um objeto não evidente, de evitar o dogmatismo.

Desta forma, pode-se notar que, de diversas maneiras, a dúvida e o ceticismo assinalam práticas, estados e atitudes opostas e até mesmo contraditórias entre si. Podemos, agora, retomar estes pontos sob outro ponto de vista, ao analisar o caminho traçado por um dos intérpretes que aborda frontalmente a questão do "Ceticismo sem Dúvida" de Sexto Empírico e encontar um modo de responder a ele. Lorenzo Corti (2012, p.58) afirma:

Por que Sexto não caracteriza o cético com a palavra "dúvida" - por que, por exemplo, ele não define o cético como alguém que está num estado de dúvida sobre qualquer questão? Porque o estado de dúvida é um estado de não crença. E, 
para Sexto, o que é crucial não é que o cético não tenha crenças, mas, antes, que ele não efetue nenhum ato de julgamento.

Como vimos, ao se considerar a dúvida um "estado de não crença", torna-se obscura a distinção entre dúvida e suspensão do juízo. Se uma diferença fundamental entre elas, a característica dinâmica de hesitação e oscilação da dúvida, é deixada de lado, como é possível entender a distinção entre dúvida e suspensão? Ao comparar o cético pirrônico com o "cético cartesiano", Corti identifica diferença entre eles da seguinte maneira:

O cético cartesiano não crê que p/que $\sim$ p; o cético pirrônico não julga que p/que $\sim$ p. E crer que p não é o mesmo fenômeno que julgar que p. A crença é um estado (que tem uma certa duração) e o julgamento, um ato (que tem lugar num certo instante). O cético pirrônico é caracterizado como um indivíduo que não realiza atos de julgamento com relação a seu objeto de investigação; o cético cartesiano, como alguém que não está em um estado de crença com relação ao seu objeto de investigação. (2002, p.57.)

Para Corti, a diferença entre o cético pirrônico e cartesiano repousaria na ausência, de um lado, de atos de julgamento e, de outro, de um estado de crença. Deste modo, para além da distinção entre crença e julgamento, Corti parece entender que a suspensão e a dúvida possuam uma mesma estrutura. Segundo Corti, a única diferença entre dúvida e epoche seria que esta consistiria na suspensão de um ato do julgamento, ao passo que a dúvida assinalaria um estado de não crença.

Deste modo, na leitura de Corti, a diferença entre a dúvida e a suspensão está condicionada à distinção entre o estado de crença e o ato de julgar. Porém, a questão de se há dúvida no Pirronismo não parece depender da distinção entre crença e juízo. A distinção entre dúvida e ceticismo não está condicionada à discussão sobre o objeto da epoche; ou seja, sobre o que o cético se suspende, e, em particular, se aquilo do que o cético se suspende seriam crenças ou juízos. Ainda, a distinção entre ato e estado não é crucial para esta discussão, pois a 
epoche pode ser entendida de mais de uma maneira, ou possuir mais de uma dimensão, podendo-se entendê-la não apenas como o ato de suspender-se, mas como um estado, o de "estar suspenso". Logo, equacionar a dúvida a um estado, e a suspensão a um ato pode ser considerado um equívoco, na medida em que não se obtém através disso nenhuma distinção essencial entre dúvida e suspensão. Sexto Empírico frequentemente descreve a epoche como um estado mental, e não apenas como o ato de suspender-se. Em HP I 203, Sexto escreve:

Sempre que digo "a cada argumento um argumento equivalente pode ser contraposto" o que digo, com efeito, é que "a cada argumento investigado por mim, que estabelece algo que me parece dogmático, parece-me haver outro argumento que estabelece algo dogmaticamente equivalente ao primeiro do ponto de vista de sua credibilidade ou falta de credibilidade", de tal forma que o proferimento desta fórmula não é dogmático, mas consiste em uma expressão de uma afecção humana, algo que é aparente a quem é afetado.

Hankinson (1995, p. 251-2) sugere que esta passagem esclarece que, ao usar o termo afecção (pathos), Sexto não se refere apenas a impressões sensíveis, mas também a estados mentais. O conteúdo de uma afecção, enquanto diz respeito àquilo que um indíduo sofre ou experiencia, pode ser tanto sensível quanto mental. Neste sentido, a epoche consistiria no estado mental de estar "em suspenso". Cabe perguntar, portanto: quais são os sentidos ou dimensões da epoche no texto de Sexto Empírico?

Como a epoche é um conceito originalmente estoico, segundo Marcondes (2007, p.73) um bom ponto de partida para compreender a epoche pirrônica é em referência ao quadro conceitual das teorias aristotélica e estoica do juízo. Distinguem-se três fases na teoria aristotélica do juízo ${ }^{43}$ :

1) uma fase preparatória em que elaboramos o juízo relacionando conceitos; 2) a fase seguinte em que temos o ato de julgar que algo ocorre ou não, propriamente

43 Sigo aqui a análise de Danilo Marcondes (2007). 
dito, isto é, em que se estabelece a relação com o real, em que se dá o assentimento, em que consideramos que algo é (ou não) verdadeiro; e, finalmente, 3) o estado em que acreditamos ou somos de opinião de que as coisas são (ou não) assim, tratando-se portanto de uma atitude mental ou psicológica, uma espécie de compromisso ou engajamento, que nos leva à decisão de afirmar (ou negar).

Para Aristóteles, há três fases envolvidas em se tomar algo como verdadeiro: uma fase preparatória de formação de um juízo, em que se dá a relação entre conceitos; o ato de julgar propriamente dito; e a fixação do juízo como um compromisso definido, dando origem a uma opinião, crença ou convicção; a uma certa atitude mental que sustentamos em relação ao real. De acordo com a teoria estoica do juízo, o assentimento consiste em um ato mental, constitutivo do juízo, que envolve a deliberação racional e voluntária a respeito do conteúdo proposicional recebido por uma impressão. Primeiramente, recebemos uma impressão, através da qual algo nos afeta, produzindo-se em nós um conteúdo proposicional para esta impressão. Por fim, ocorre o assentimento, pode-se conferir ou não o assentimento ao conteúdo de determinada impressão. Como vimos, na exposição sobre o critério do ceticismo, Sexto Empírico afirma que o cético não rejeita as impressões que o afetam involuntariamente. $\mathrm{O}$ assentimento (synkatathesis) deve ser entendido como um ato voluntário e racional: o que está em jogo com a noção de assentimento é uma decisão deliberada pela qual se aceita o conteúdo proposicional de uma impressão como verdadeiro (cf. Acad. II, 37). Após cotejar o que Sexto descreve sobre a suspensão com as teorias aristotélica e estoica do juízo, Marcondes (2007, p.77) enumera os seguintes “sentidos ou dimensões" que se pode encontrar na epoche pirrônica:

1) uma dimensão de caráter mais lógico, dizendo respeito à interrupção do processo que leva da consideração de uma proposição à formulação do juízo correspondente; 2) uma dimensão que poderíamos considerar mais psicológica, consistindo na retenção do impulso de julgar, por não haver condições ou motivos para isso; 3) uma dimensão performativa, o "Eu suspendo," relativa à ação propriamente dita e ao estado em que aquele que "suspende" se encontra, no qual este se abstém quanto a uma decisão ou a uma tomada de posição, estando assim "em suspenso". "Suspender" pode significar, portanto, interromper um processo, reter um impulso e abster-se quanto a uma tomada de decisão. 
A epoche pode ser entendida como um ato: o ato de interrupção do processo judicatório, de modo que o cético não se pronuncia, não julga a favor ou contra nenhuma das alternativas. Enquanto retenção do impulso de julgar, o cético é capaz de recusar e evitar a tomada de decisão diante de um conflito que se mostra aporético. Assim, a epoche assinala a atitude de evitar o impulso a emitir um juízo a respeito de um conflito e de decidi-lo quando uma decisão mostra-se aporética. Neste sentido, a suspensão aponta para uma atitude ou propensão intelectual do investigador cético, que consiste em reter o impulso de dogmatizar. Por fim, a epoche assinala uma afecção ou estado mental, de acordo com o qual o cético mantém-se indiferente em relação às teses em conflito das quais se suspende, e não se compromete com elas. Ao suspender-se, está “em suspenso", sendo o seu estado mental um estado de neutralidade ou indiferença em relação àquilo de que se suspende. Em HP I, 190, Sexto escreve:

A expressão "não mais isso ou aquilo" indica também a afecção (páthos) que é a nossa, segundo a qual, pelo fato da força igual das coisas em oposição, somos conduzidos ao equilíbrio (arrepsía).

O cético possui um estado mental ou uma afecção mental que lhe é própria, que é caracterizada, sobretudo, pelo equilíbrio; é marcada pela força igual dos objetos opostos, gerando a indiferença em relação a ambos. Portanto, é possível identificar na epoche pirrônica ao menos três dimensões complementares:

1) o ato de interromper ou sustar o processo judicatório, de modo a não afirmar ou negar nada acerca de algo não evidente;

2) uma atitude de não-asserção, de acordo com a qual se retém o impulso a julgar e com isso se evita o dogmatismo, 
3) um estado mental (pathos dianoias - na tradução de Estienne, status mentis) marcado pelo equilíbrio, indiferença e tranquilidade; não pela oscilação, hesitação, indecisão ou perturbação.

Desse modo, pode-se novamente notar que o processo de investigação cético não é "dubitativo": o cético não vacila ou oscila o seu assentimento durante a investigação das teses dogmáticas. Pelo contrário, as investiga de modo a buscar o equilíbrio entre elas, sendo justamente devido à constatação de que as alternativas opostas são equipolentes (em matéria de persuasão, convencimento) que o cético é levado ou chega à suspensão. Esta, sendo entendida como atividade ou ato, marca o distanciamento do investigador em relação ao conflito investigado, ao passo que, em um estado de dúvida, se está entre as alternativas em conflito - distanciarse das alternativas significa a dissolução da dúvida. E deve-se frisar que a epoche não é uma solução para a dúvida, ou o "modo cético" de responder à dúvida: nem é a dúvida o que engendra a epoche, mas a aporia, nem é a dúvida o resultado da investigação cética, mas a suspensão. O ceticismo não começa nem termina com a "dúvida". Portanto, deve-se evitar confundir a dúvida com a crença, com a descrença, ou com a suspensão - seja esta pensada como suspensão do juízo, do impulso a julgar, ou como a suspensão do próprio dogmatismo. Como a dúvida não é um estado de não crença, "estar em suspenso" já assinala uma condição mental diferente de um estado de dúvida.

Em todos os seus sentidos ou dimensões, a epoche não apenas claramente distingue-se do conceito de dúvida, como podem ser considerados conceitos opostos e mesmo mutuamente excludentes em vários aspectos. Nenhuma das etapas do procedimento equivale ou de fato confunde-se com a dúvida. No caso da epoche em particular, seja em sua dimensão como ato, atitude ou estado mental é incoerente pensá-la como dúvida.

De um lado, tem-se a vacilação e oscilação do juízo, o impulso a julgar, e um estado de hesitação e indecisão e a inserção da consciência entre as 
alternativas, que constituem o seu horizonte, e, de outro lado, o ato de suspensão ou interrupção do juízo, a atitude de rejeição do impulso de julgar, e um estado mental de equilíbrio e indiferença. Portanto, Sexto Empírico não fala de dúvida porque 1) não há nenhuma relação direta entre ceticismo e dúvida e, sobretudo, porque 2) a atitude cética e o estado mental do cético são contraditórios com o conceito de dúvida.

A atitude cética é reter o impulso a julgar, e evitar dogmatizar a respeito de conflitos indecidíveis sobre objetos não evidentes. Estando "em suspenso", o estado mental do cético é de equilíbrio e tranquilidade, "impertubabilidade" - o oposto da oscilação, inquietude e indecisão do estado de dúvida, no qual se deseja e se busca tomar uma decisão, chegar a um juízo ou obter uma crença.

Ao se introduzir a noção de dúvida no ceticismo, não mais é possível compreendê-lo em sua significância própria, e assim inevitavelmente surgem diversas contradições e inconsistências. Uma suposta inconsistência da filosofia cética, frequentemente assinalada no período moderno, diz respeito à sua finalidade prática. Como pode o cético buscar a tranquilidade, se professa duvidar de tudo e estar sempre em dúvida? O cético afirma ter como finalidade a tranquilidade (ataraxia), ou seja, o contrário do que se imagina de alguém que buscasse a dúvida como um fim. Nota-se que, paralelamente à acusação desta inconsistência, está o processo de transformação do ceticismo: ao ser reinterpretado como dúvida, a ataraxia é um dos termos céticos mais difíceis de serem mantidos nesta releitura do ceticismo. Como consequência, o ceticismo na modernidade perde as características de busca da tranquilidade e da felicidade. Como o ceticismo passa a ser sinônimo de dúvida, indecisão, e perturbação, não mais se pode entendê-lo como uma filosofia prática, como um modo de vida coerente e feliz.

Hegel, voltando-se contra este erro histórico nas Lições sobre a História da Filosofia (1825-6), esclarece bem este ponto: a dúvida é oposta à ataraxia. 
Não devemos traduzir skepsis como uma "doutrina da dúvida". O ceticismo não é uma dúvida, pois a dúvida é justamente o oposto da tranquilidade que deve ser o resultado do ceticismo. A dúvida [Zweifel] deriva de dois [zwei]; é uma vacilação entre dois ou mais pontos de vista, uma pessoa se decide a favor nem de um ou de outro, mas deve se decidir a favor de um ou de outro, apesar de duvidar de cada um. (...) Esta posição da dúvida é o oposto do ceticismo. A dúvida é inquieta porque quer encontrar quietude em algo oposto à quietude, e não pode achá-la em lugar nenhum. O ceticismo, entretanto, é igualmente indiferente a um e ao outro, e não deseja encontrar segurança em um dos elementos opostos. Esta é a posição cética da ataraxia. ${ }^{44}$

Ao ser identificado com o conceito de dúvida é contraditório pensar que a finalidade do ceticismo seja a ataraxia. Logo, com a introdução do conceito de dúvida no ceticismo no período moderno, este paulatinamente deixa de ser pensado como uma filosofia de cunho ético, como uma filosofia prática. A ataraxia é tão evidentemente contraditória com a dúvida que resiste à sinonímia entre ceticismo e dúvida, sendo, portanto, abandonada - torna-se uma “inconsistência do ceticismo”. Mas não apenas a ataraxia é deixada de lado, como todos os termos técnicos do ceticismo - aporia, epoche, diaphonia e skepsis -, uma vez pensados através do conceito de dúvida, são transformados e perdem a sua identidade. E o próprio cético viria a receber uma nova identidade, ou novas identidades, inteiramente diferentes da concepção antiga e, de diversas formas, radicalmente opostas: uma identidade despersonificada, em vez de investigador ou filósofo, uma personagem filosófica, que faz apenas sempre e em todos os casos duvidar, que está constantemente perplexo, indeciso, perturbado. À guisa de conclusão:

1) O conceito de dúvida não está presente no procedimento investigativo do ceticismo pirrônico, não sendo equivalente a nenhuma das suas etapas;

2) Duvidar não é a "habilidade específica" do ceticismo. O cético não é quem exerce a capacidade de duvidar, mas a "capacidade de oposição";

44 Hegel (2006), p. 307-8. 
3) A dúvida não está na origem do ceticismo. Não se torna cético porque se está em dúvida. A origem do ceticismo é o estado aporético, o impasse em que se encontra o objeto da sua investigação. O ceticismo não nasce da dúvida, nem é uma atitude em relação à dúvida, uma “solução" para ela ou o seu "antídoto": a sua atitude é a de não asserção e de evitar o impulso a dogmatizar;

4) Estar em dúvida não é o fim almejado pelo cético. O resultado obtido da sua investigação é a tranquilidade, não a inquietação. Não é o seu modo de viver, de modo que não está sempre indeciso, hesitante ou perplexo, mas vive de acordo com os fenômenos, com o que aparece;

5) "Ser cético" (em relação a p e p), ou "estar em suspenso" (em relaçao e p e $\sim$ p) dizem respeito a uma atitude cognitiva e a um estado mental que são opostas à “estar em dúvida” (entre p e $\sim$ p).

Portanto, pode-se afirmar que não só o ceticismo não se confunde com a noção de dúvida, mas que com a introdução desta noção no ceticismo fica prejudicada a possibilidade de compreensão da sua significância própria. Podese explicar o fato textual de não haver dúvida na descrição do ceticismo de Sexto Empírico devido ao fato de que o ato, o estado mental, e a atitude intelectual que são próprios à prática do ceticismo sejam inteiramente distintos da dúvida, seja a dúvida pensada enquanto ato, estado mental ou atitude. Ao se misturarem, confundirem e se tornarem equivalentes, não é mais possível compreender o que é o ceticismo pirrônico, tanto quanto o próprio conceito de dúvida se torna vago e impreciso.

Deste modo, pode-se afirmar que há uma razão teórica para Sexto não descrever o seu cético através da noção de dúvida, que diz respeito à significância própria do ceticismo pirrônico. Pirronismo e dúvida não têm necessariamente uma relação de parentesco, semelhança ou proximidade. O ceticismo que Sexto descreve é independente do conceito de dúvida e seus derivados, bem como a 
noção de dúvida é independente do ceticismo e assinala, fundamentalmente, um fenômeno da consciência, um estado mental.

A dúvida é um fenômeno mental em que a consciência oscila entre duas ou mais alternativas devido a algum obstáculo no caminho de um juízo a seu respeito e, enquanto se está em um estado de dúvida, as alternativas constituem o horizonte em que a consciência transita, sendo levada a este movimento pelo impulso de julgar ou desejo de decidir o conflito em que se encontra. O estado de dúvida, desta forma, caracteriza-se como um estado de indecisão, vacilação, hesitação do espírito, gerando sentimentos de perturbação, irritação, ansiedade. Já a suspensão não decorre simplesmente da existência de alternativas opostas, mas da investigação de um conflito equipolente, cujo resultado é a sua indecidibilidade. Deste modo, a suspensão consiste no movimento ou ato de afastar-se do conflito como um todo, tendo por base a resistência ao impulso de julgar e gerando o estado mental em que se está “em suspenso".

De acordo com a descrição de Sexto Empírico, a mente do cético não oscila, mas, "em suspenso", é capaz de viver uma vida tranquila e comum, sem julgar como as coisas seriam para além do modo como lhe aparecem. A dúvida representa um obstáculo para certa visão de mundo; ao passo que o ceticismo é ele próprio uma visão de mundo, uma adesão filosófica, cuja significância é, ao mesmo tempo, prática e intelectual. 


\section{O Desaparecimento e a Redescoberta do Ceticismo no Renascimento}

Cícero comenta em De natura Deorum $(\mathrm{I}, \mathrm{v}, 11)$ que a filosofia acadêmica está em declínio entre os gregos. E os seus Academica encontram pouco eco em seus contemporâneos e nas gerações seguintes, de modo que, segundo Schmitt (1972, p.23), “é quase em vão que se busca uma continuidade da tradição acadêmica no pensamento romano após Cícero". Plínio, o Velho (23/4 - 79), Quintiliano (30/5 - ca.100) e Plutarco (46-119) citam a obra, e Minucius Felix (fl.200-40) conhecem o texto em primeira mão, que é mencionado por diversos autores no contexto da patrística, que em sua maioria, escrevem do Norte da África, dentre os quais se pode destacar Eusébio, Jerônimo, Ambrósio, Lactâncio (250-325), e especialmente Santo Agostinho. O último autor antigo a conhecer os Academica parece ter sido Martianus Capella (fl. ca. 425). Durante o período medieval, entre os séculos V e XII, encontram-se escassas referências à obra (ver Schmitt, 1972, pp.33-42; Hunt, 1998, pp.18-25).

Santo Agostinho dedica uma das suas primeiras obras, Contra Academicos, à tentativa de refutação dos argumentos encontrados nos Academica de Cícero. Como nestes a posição que se destaca é o probabilismo endossado por Cícero, esta é a posição filosófica que Santo Agostinho busca com mais veemência refutar em Contra Academicos. O último golpe de Agostinho contra a doutrina acadêmica é sustentar, contra a doutrina do probabilismo e a versimilhança, a fé e a verdade revelada baseadas na autoridade de Cristo como critério de verdade. Esta estratégia seria influente para o pensamento cristão, como se pode ver, por exemplo, em Henrique de Gandavo e Martinho Lutero. 
Deste modo, pode-se considerar que o Contra Academicos volta-se especialmente contra o probabilismo de Cícero. Agostinho chega mesmo a ridicularizar a ideia de um critério de verossimilhança; pois como alguém poderia se guiar por aquilo que se aproxima à verdade se, no entanto, não a conhece (ver Contra Academicos, II, 7, 19; III, 18, 40, etc.)? Agostinho chega mesmo a defender Arcesilau, sustentando que tinha bons motivos para atacar Zenão ao defender os princípios da filosofia platônica contra a sua doutrina fisicalista da alma (Ibid., III, 17, 38). As maiores autoridades para Agostinho, que se estabelecem como critérios de verdade e garantias da certeza, são, em matéria religiosa, Cristo, e no uso da razão ainda não iluminado pela fé, a filosofia de Platão.

Tanto Agostinho (que não lia o grego à época em que escreve Contra Academicos ${ }^{45}$ ) quanto Lactâncio baseiam o seu conhecimento sobre a tradição cética exclusivamente nos Academica de Cícero, de modo que ambos parecem desconhecer inteiramente o ceticismo pirrônico (Floridi, 2002). Deste modo, Agostinho não utiliza o termo "cético" em Contra Academicos. Nas principais fontes da tradição cética antiga em Latim, Cícero e Santo Agostinho, discute-se apenas a Nova Academia, sem se fazer nenhuma referência aos skeptikoi, de modo que o termo não figura em suas obras, o que seria capaz de explicar a desconcertante inexistência do termo "cético" no vocabulário latino medieval. Nos Academica de Cícero e no Contra Academicos de Santo Agostinho, debate-se o pensamento neoacadêmico, sem jamais se fazer referência aos termos "cético" e "ceticismo". Neste sentido, Floridi afirma (2002, p.13) que já à época de Agostinho é

[...] o ceticismo acadêmico transmitido em latim que havia se tornado o tipo de ceticismo conhecido por filósofos e teólogos, à custa do Pirronismo e dos textos gregos de Sexto Empírico.

45 Ver Floridi, 2002, p.13. 
Dentre os possíveis motivos que teriam contribuído para esta falta de interesse no ceticismo antigo durante o período medieval, Luciano Floridi (2002, p.15) elenca a questão linguística, já que poucos a esta época sabiam o grego, bem como o latim medieval já havia se distanciado de suas fontes clássicas, além de outros fatores, tais como o "dogmatismo religioso (a Bíblia torna-se a fonte confiável para uma completa semantização do real)", interesses teológicos, e a rejeição de “investigações epistemológicas mundanas”. Danilo Marcondes menciona ainda como um fator determinante o fato de Santo Agostinho, em Contra Academicos, ter oferecido uma refutação para o pensamento neoacadêmico, baseada na fé e na verdade revelada, ao submeter a razão à autoridade de Cristo. Como já teriam sido refutados, o interesse pelos acadêmicos gradualmente diminuiria. Segundo Marcondes (A tradição cética, s/d, p. 11):

\begin{abstract}
A influência de Santo Agostinho no Ocidente em todo o período medieval explica em grande parte o desinteresse pelo ceticismo. Referências ao ceticismo antigo e discussões de questões céticas estão, salvo algumas exceções, ausentes da Filosofia medieval.
\end{abstract}

Um quadro similar delineia-se para o ceticismo pirrônico. Praticamente é desconhecido no ocidente latino durante o período medieval, situação que perdura do século IV ao século XV. Há indicações de que o conhecimento do ceticismo pirrônico não era incomum até o século IV, ou que mesmo houvesse ainda céticos pirrônicos, pois Gregório de Naziano (c. 330-389) adverte:

Desde que os Sextos e Pirros e a prática de argumentar pelos lados opostos, como uma doença vil e maligna, infectaram as igrejas, o palavreado tomou as vezes da cultura, e - como é dito no Livro dos Atos sobre os Atenienses - passamos todo o tempo falando ou ouvindo uma ou outra novidade qualquer (Oratio 21, caput 12, pg. 35, col. 1095 citado em : Floridi, 2002, p. 12).

Portanto, pode-se afirmar que, após o século IV, pouca ou nenhuma atenção foi destinada à filosofia cética antiga, senão esporadicamente, e, nesses casos, 
especialmente em obras de eruditos bizantinos. Estes estavam, segundo Floridi (2002, p. 20-24), em uma situação mais favorável: além de conhecer a língua grega, e parecem ter desfrutado de acesso contínuo ao menos a algumas fontes céticas originais. Deste modo, tanto o ceticismo acadêmico quanto o pirrônico haviam caído em quase total esquecimento. A tradição cética teria, por assim dizer, chegado a um fim.

É somente no contexto do Renascimento italiano, em particular florentino, que se pode localizar um ressurgimento da filosofia cética antiga. Com a ampliação do interesse pela Antiguidade que se dá com o humanismo renascentista (Petrarca cita Arcesilau e Carneades em De sui ipsius et multorum ignorantia), são redescobertos no início do período moderno não apenas o ceticismo, mas uma série de outras doutrinas gregas e orientais, tais como o estoicismo, o epicurismo e a cabala, inteiramente desconhecidos no Ocidente, e são recuperadas obras de filósofos clássicos, inclusive grande parte da obra de Platão e Aristóteles, e outros que apenas se conhecia pelo nome.

Após o século IV, portanto, o pirronismo praticamente desaparece do cenário intelectual europeu, especialmente no Ocidente latino, e tampouco a tradição acadêmica, que se fazia disponível, sobretudo através do Contra Academicos, tem uma presença significativa. O conhecimento dos Academica viria a retornar primeiramente na França, a partir do século XIII ${ }^{46}$, e logo após na Itália, onde, no início do século XV, manuscritos e o conhecimento da obra de Sexto Empírico começam a se difundir entre os humanistas italianos, e o capítulo A Vida de Pirro, de Diógenes Laércio, é publicado em latim (1432).

46 É inclusive do Norte da França que provêm os manuscritos mais antigos da obra. Ver Hunt, 1998. 


\section{A redescoberta das fontes céticas}

Costuma-se remontar a retomada da filosofia cética antiga no início do período moderno à redescoberta das suas duas principais fontes clássicas, a obra de Sexto Empírico (Hipotiposes Pirrônicas e Adversus Mathematicos) e o capítulo "Pirro", da Vida e Doutrina dos Filósofos Ilustres, de Diógenes Laércio, o que se dá em conexão à retomada e à ampliação de interesse pelos Academica de Cícero. Os manuscritos de Sexto Empírico são redescobertos, e reintroduzidos ao ocidente na primeira metade do século $\mathrm{XV}$, no contexto do renascimento italiano, particularmente florentino, o que coincide com a primeira tradução latina da Vida de Pirro, de Diógenes Laércio, e com a ampliação de interesse pelos Academica de Cícero.

A “Vida de Pirro" (Vita Pyrrhonis) é publicada em 1432 por Ambrogio Traversari. Esta é a primeira tradução para o Latim do capítulo "Pirro" da Vida $e$ Doutrina dos Filósofos Ilustres, de Diógenes Laércio (Livro IX, cap. 11). Segundo Schmitt, é esta tradução que introduz a palavra latina scepticus ao vocabulário latino. Deste modo, é a partir desta tradução que os termos "cético" e "ceticismo" são introduzidos às línguas modernas, tornando-se paulatinamente em expressões bem conhecidas ${ }^{47}$.

Deste modo, pode-se afirmar que é a publicação da Vita Pyrrhonis de Traversari que reintroduz ao Ocidente latino o conhecimento da filosofia cética propriamente dita. E, a partir desta tradução, Pirro passa a ser considerado o principal representante da recém-descoberta escola da filosofia helenística. ${ }^{48}$

Segundo Floridi (2002), o primeiro contato do Ocidente com Sexto Empírico pode remontar a Georgios Plethon (1389-1464), erudito bizantino que se julgava a reencarnação de Platão, conhecia Sexto e era adverso ao ceticismo. Plethon entra em contato com os humanistas italianos a partir da sua visita à Itália em 1438-39 durante o Concílio de Ferrara (Floridi, 2002), possivelmente trazendo consigo um manuscrito de Sexto Emppírico. Dentre os seus correspondentes,

47 Ver Schmitt (1972 p. 13), e artigo (1983), (Copenhaver/Schmmit, 242) e Floridi (2000).

48 Ver Naya (2009). 
estão Francesco Filelfo (1398-1481) e o Cardeal Bessarion (1395-1472), dois humanistas que possuíam manuscritos da obra de Sexto Empírico. Em suas cartas, Francesco Filelfo menciona regularmente o ceticismo e Sexto Empírico. Como as cartas de Filelfo foram um sucesso editorial da época, e circularam através de sucessivas edições ao longo do século XV, é plausível pensar que tenham auxiliado na difusão do conhecimento da filosofia cética e Sexto Empírico.

Floridi mostra que havia um número consideravelmente maior de manuscritos de Sexto Empírico em circulação durante o Renascimento, tanto em grego quanto em latim, do que anteriormente era estimado (especialmente por Popkin e Schmitt); e cuja circulação não seria tão restrita. Isto forneceria a "evidência de uma difusão perceptível do conhecimento sobre os escritos pirrônicos durante os séculos XV e XVI" ${ }^{49}$. Nota-se que era o costume da época que, sempre que um manuscrito de interesse fosse emprestado, uma cópia seria feita, e assim de uma pequena quantidade de originais, de acordo com o grau de interesse gerado pela obra, um número crescente de cópias entrava em circulação.

Deste modo, de acordo com Floridi, há "seis caminhos distintos de difusão dos textos pirrônicos e recepção das doutrinas céticas durante os séculos XV e XVI” (Floridi, 2002, p.25ss). As principais vias de difusão da obra de Sexto seriam:

1) a correspondência entre eruditos bizantinos e os humanistas italianos;

2) a redescoberta de manuscritos de Sexto Empírico, lograda independentemente pelos humanistas italianos;

3) o acúmulo de manuscritos de Sexto e a ampliação da sua difusão (que culminam com a publicação das traduções latinas da obra de Sexto da década de 1560).

49 Floridi, 2002, p. 29. 
Deste modo, no contexto do humanismo renascentista, em particular florentino, a retomada da filosofia cética ocorre ao menos a partir da década de 1430, quando é publicada a tradução da "Vida de Pirro" por Ambrogio Traversari, manuscritos e o conhecimento da obra de Sexto Empírico começam a circular entre os humanistas italianos. Os escritos de Sexto Empírico viriam a ser publicados em latim na década de 1560; as Hipotiposes Pirrônicas, em 1562, são traduzidas por Henri Estienne (Henricus Stephanus, 1528-1598), e os Adversus Mathematicus são traduzidos em 1569, por Gentian Hervet (Gentiannus Hervetus, 1499-1584), que publica uma edição da obra completa de Sexto, incluindo à sua tradução de Adversus Mathematicos a tradução de Estienne das Hipotiposes. Paralelamente a estes modos de difusão, Floridi explicita os principais modos de recepção da obra de Sexto Empírico:

1) A recepção inicial dos textos de Sexto teria sido caracterizada por interesses "antiquários, históricos e filológicos". Neste momento a obra de Sexto é lida, sobretudo, como um texto literário e fonte documental sobre a filosofia antiga.

2) Em seguida, pode-se notar a "avaliação filosófica do pirronismo como uma posição cética", sendo que, quando isto acontece, teria sido "inicialmente uma questão de interpretações éticas e religiosas".

3) Até que, "paralelamente ao crescimento gradual do número de manuscritos de Sexto disponíveis, e ao desenvolvimento inicial de usos cristãos e éticos dos argumentos pirrônicos", ocorre o deslocamento geográfico da Itália para o norte da Europa, em especial para a França, onde um uso "mais epistemológico" dos escritos de Sexto começa a se desenvolver, sendo do final do século XVI ao início do século XVII sobretudo moral e religioso. 
O caminho percorrido pelas ideias céticas antigas e o seu percurso de difusão, influência e transformação no pensamento moderno parece assim delinear-se mais claramente. Nota-se que, para Floridi (2002, p.30), a recepção inicial da obra de Sexto Empírico se dá em conexão aos interesses humanistas, e não propriamente filosóficos. Apenas um século após o uso dos textos céticos antigos estar voltado para os interesses próprios dos humanistas italianos é que apareceria uma elaboração filosófica das ideias céticas antigas. Isto ocorre, em um primeiro momento, em relação a questões teológicas (Erasmo, Lutero, Hervet), éticas (Montaigne, La Mothe Le Vayer, libertinos eruditos), e posteriormente em conexão com questões epistemológicas (Charron, Descartes; mas mesmo em Charron ainda em relação a questões religiosas) e científicas (Mersenne, Gassendi) ${ }^{50}$.

Portanto, o percurso da retomada e do uso ou apropriação das fontes céticas antigas desenvolve-se, cronologicamente, em conexão aos seguintes domínios: 1) Interesses humanistas; 2) Teologia; 3) Ética; 4) Epistemologia; 5) Nova ciência.

\section{A retomada dos Academica}

Embora a obra de Cícero jamais tenha sido perdida ou esquecida, sendo algumas editadas continuamente durante todo o período medieval, como o $D e$ Oficiis, outras eram quase completamente desconhecidas, como é o caso dos Academica.

De um modo geral, as obras filosóficas [de Cícero] - com exceção das que tratam da filosofia moral - não são bem conhecidas durante a Idade Média e é apenas no século XV e posteriormente que recebem maior proeminência e passam a

50 Ver Richard Popkin (2003). 
desempenhar um papel mais importante nas discussões filosóficas. (Schmitt, 1972, p. 35).

Deste modo, é raro o conhecimento direto dos Academica previamente aos séculos XIV e XV (Schmitt, 1972). O movimento de ampliação de interesse pelos Academica pode ser localizado na Itália, a partir de Petrarca (1304-1374), que o inclui na lista dos seus livros favoritos sob o título Hortensius, e o cita em algumas de suas obras, estimulando o interesse pela sua leitura em seu círculo de influência. Em algumas de suas obras, como De sua própria Ignorância e a dos Outros (1367) Petrarca menciona diretamente o Academica e expõe brevemente as questões nele discutidas. Afirma Schmitt (1972, p. 44):

Quando chegamos à época de Petrarca e do surgimento do movimento humanista, encontramos uma difusão bastante elevada do Academica. Mais manuscritos da obra são copiados, referências a ela aparecem com mais frequência em cartas e pode ser encontrado com mais frequência em bibliotecas de todos os gêneros.

Também Dante inclui-se dentre os primeiros a se referir aos Academica. No Convivio, escrito entre 1304 e 1307, apresenta os acadêmicos no contexto de uma discussão sobre a virtude e a moralidade. Para Dante, os acadêmicos teriam a sua origem em Sócrates, mas deste não derivariam o seu nome, mas sim da Academia, devido à Sócrates "nada ter afirmado".

Estes eram chamados de acadêmicos, dentre os quais Platão e Espeusipo, seu sobrinho, assim chamados porque o lugar onde Platão estudava era a Academia, e não derivavam o seu nome de Sócrates porque na filosofia deste nada era afirmado. 51

51 "E questi furono Academici chiamati, sì come fue Platone e Speusippo suo nepote: chiamati per luogo così dove Plato studiava, cioè Academia; nè da Socrate presero vocabulo, però che ne la sua filosofia nulla fu affermato. Veramente Aristotile, che Stagirite ebbe sopranome, e Zenocrate Calcedonio, suo compagnone, [e per lo studio loro], e per lo 'ngegno [singulare] e quasi divino che la natura in Aristotile messo avea, questo fine conoscendo per lo modo socratico quasi e academico, limaro e a perfezione la filosofia morale redussero, e massimamente Aristotile. E però che Aristotile cominciò a disputare andando in qua e in lae, chiamati furono - lui dico, e li suoi compagni - Peripatetici, che tanto vale quanto 'deambulatori'. E però che la perfezione di questa moralitade per Aristotile terminata fue, lo nome de li Academici si spense, e tutti quelli che a 
Através de Petrarca dissemina-se o interesse pelos Academica, de modo que se pode notar no final do século XIV e início do século XV uma ampla retomada de interesse pela obra e o seu conhecimento direto entre os humanistas. Coluccio Salutati (1331-1406), Lorenzo Valla (1407-1457), Marsilio Ficino ${ }^{52}$ (1433-1499) e Rudolf Argicola (1444-1485) se referem explicitamente ao Academica e ao probabilismo ciceroniano. Nicolau de Cusa (1401-1464) refere-se tanto aos Academica quanto ao Contra Academicos de Agostinho ${ }^{53}$. O cardeal Giovanni Dominici (1356-1419) e os humanistas Guarino da Verona (1360-1460), Giovanni Aurispa (1376-1459), Poggio Bracciolini (1380-1459), Pier Candido Decembrio (1399-1477), Bartolomeo Scala (1430-97), Francesco Patrizi (1413-94) ou possuíam uma cópia do Lucullus ou, através das referências que fazem à obra, demonstram conhecê-la diretamente ${ }^{54}$. Deste modo, o conhecimento dos Academica difunde-se entre os humanistas italianos, bem como aumenta a circulação de manuscritos entre o final do século XIV e início do século XV. Segundo Schmittt (1972, p.48):

Apesar de este despertar de interesse pelos Academica no final do seculo XIV e início do século XV, não encontramos, até onde pude descobrir uma emergência do ceticismo.

questa setta si presero Peripatetici sono chiamati..." (Dante, Il Convivio, IV, 6. 14-16, citado em Hunt, 1998, p. 31).

52 Apesar do seu esforço de recuperar a obra platônica, Ficino não confere muita atenção à "fase cética" da Academia: "Embora Ficino se pronuncie pouco sobre os Academica de Cícero propriamente, ele considera a questão sobre qual posição os céticos acadêmicos ocupam na tradição platônica. Ele certamente não trata a questão in extenso, mas de alguns comentários ocasionais podemos concluir que Ficino via pouca utilidade pela assim chamada Nova Academia e sentia que esta tendência cética tinha pouco lugar no verdadeiro platonismo. Por exemplo, a respeito da alma, ele claramente filia-se pelo Platonismo de inclinação dogmática contra o probabilismo de Carnéades" (Schmitt, 1972, p. 160). Ficino e a Academia platônica de Florença, deste modo, não parecem ter exercido um papel especial na retomada de interesse pelos Academica ou pela filosofia cética antiga.

53 Schmitt, 1976, p. 53.

54 Ver Hunt, 1998, cap. 2 e Schmitt, 1972, p. 47. 
Nesta retomada de interesse pela obra filosófica de Cícero, no entanto, Schmitt frisa que o conteúdo propriamente filosófico dos Academica atrai pouca atenção. Os humanistas produzem comentários e escólios dos Academica, mas são "todos essencialmente de natureza filológica e de pouco valor para a interpretação filosófica da obra":

Os humanistas que voltam sua atenção para o Academica estavam interessados mais em questões filológicas, textuais e históricas do que nas implicações filosóficas a serem descobertas no tratado de Cícero. (Schmitt 1972, p.54)

Portanto, segundo Schmitt, no Quattroccento demonstra-se pouco interesse pelo conteúdo filosófico ou "cético" dos Academica. Esta situação perduraria até o final do século XIV, ao passo que "amplo interesse foi manifestado pelo Cicero philosophus durante os séculos XV e XVI.” (1972, p. 15), podendo-se destacar Omer Talon, Giullio Castellani e Joannes Rosa como os autores mais significativos a fazerem um uso filosófico dos Academica.

Durante o século XVI foram preparadas, pela primeira vez, uma série de escólios, comentários e anotações sobre a obra, de natureza tanto filológica quanto filosófica. (Schmitt, 1972, p. 43).

De acordo com Schmitt, é principalmente a partir da década de 1540 que os Academica passam a ser objeto de comentários e análises críticas, o que demonstra uma guinada de interesse pela obra. O interesse filosófico pelos Academica atinge o seu auge especialmente durante o período entre a publicação de Loci Communes, de Philip Melanchthon (1535), e as publicações latinas de Sexto na década de 1560. Com a publicação das traduções de Sexto Empírico, este interesse cede, sendo aos poucos Sexto Empírico quem se estabelece como a principal referência sobre o ceticismo para a época. Pode-se concluir que as traduções de Sexto viriam em resposta a um interesse cada vez maior de se conhecer o ceticismo antigo, o que até então era possível somente através do capítulo a Vida de Pirro, de Diógenes Laércio, dos Academica, de Cícero, e dos manuscritos da obra de Sexto, de acesso mais restrito. 
Portanto, pode-se considerar bem documentada a redescoberta e guinada de interesse pela tradição cética antiga no período moderno, bem como se pode notar que a interpretação da retomada do ceticismo efetuada por Floridi a respeito de Sexto Empírico e Diógenes Laércio, e dos Academica efetuada por Schmitt convergem para uma mesma cronologia.

Conhecia-se o ceticismo desde a década de 1430, o que desperta o interesse, sobretudo filológico e histórico dos humanistas renascentistas, que leem os manuscritos céticos como fontes documentais sobre o passado clássico. As fontes céticas são objeto de interesses humanistas; durante a década de 1430, a Vita Pyrrhonis é publicada por Ambrogio Traversari, e manuscritos da obra de Sexto começam a circular entre os humanistas. Os Academica são publicados primeiramente em Roma, na edição da Opera Philosophica de Cícero de 1471, vindo a integrar diversas edições das suas obras ao longo do século $\mathrm{XV}$, sendo publicados separadamente apenas em 1535.

Em seguida, no início do século XVI, o ceticismo é absorvido pelas controvérsias religiosas no contexto da Reforma Protestante. Referências ao ceticismo são proeminentes no contexto das controvérsias religiosas, especialmente nos debates entre defensores da Reforma e da Contra-Reforma, mas já se pode notá-las desde o debate entre Lutero e Erasmo sobre o livre-arbítrio (1525).

Pode-se notar a convergência entre Schmitt e Floridi a respeito dos modos iniciais de distribuição e difusão das fontes textuais do Pirronismo, transmitida por Sexto Empírico e Diógenes Laércio (Floridi), e da tradição acadêmica transmitida por Cícero (Schmitt) durante o período moderno. Em ambos os casos, previamente a uma tomada de interesse genuinamente filosófico pelas fontes da tradição cética há um longo intervalo de tempo em que são objeto apenas de estudos tipicamente humanistas.

Ao frisarem que até meados do século XVI não havia um interesse genuinamente filosófico pelo conteúdo dos textos antigos, isto parece significar 
para ambos os autores que o ceticismo não havia ainda penetrado no pensamento moderno, ou na "consciência moderna", de modo que nada filosoficamente relevante haveria ocorrido. Deste modo, Schmitt e Floridi parecem subscrever à visão de Popkin, para quem não havia um "uso significativo" do ceticismo clássico previamente às publicações latinas de Sexto na década de 1560, com a exceção de Gianfrancesco Pico della Mirandola (Examen Vanitatis, 1520).

Mas pode-se perguntar: no período anterior às publicações latinas de Sexto durante mais de um século de interesses humanistas pelas fontes céticas antigas -, nada de significativo teria ocorrido para o modo de se compreender a filosofia cética antiga? Como assinalam Schmitt e Floridi, há uma produção humanista, voltada para interesses principalmente filológicos e históricos, que consiste em uma série de escólios, anotações e comentários sobre o ceticismo clássico. Portanto, como a esta época o ceticismo já havia sido difundido, não teria o pensamento humanista influenciado o modo como o ceticismo havia sido "assimilado à consciência moderna" bem como por ele transformado? Schmitt (1983, p.225) nota esta "lacuna" nos estudos do ceticismo renascentista e dos anos iniciais da sua recepção:

Apesar do fato de que até agora alguma atenção possa ter sido dada à descoberta dos detalhes precisos da retomada da doutrina cética antiga por pensadores do Renascimento, ainda nos falta um exame compreensivo do processo através do qual as ideias céticas antigas foram assimiladas à consciência moderna no início deste período.

Segundo a pesquisa seminal de Popkin, os elementos fundamentais para a assimilação do ceticismo à consciência moderna teriam sido: 1) a crise intelectual da Reforma; 2) as publicações da obra de Sexto em latim (1562, 1569); e 3) a exposição do ceticismo de Montaigne no ensaio Apologia de Raymond Sebond (1588). O que Popkin mostra em sua História do Ceticismo é o impacto da retomada do ceticismo no pensamento moderno, pois desejava apresentar o ceticismo como uma das forças atuantes em sua formação e em seu caráter filosófico. Deste modo, como busca pensar no ceticismo como uma das forças 
atuantes na formação do pensamento moderno, pode-se dizer que o "ceticismo renascentista", embora assinale o papel da reforma, não consiste no seu interesse principal.

Como buscamos entender de que modo a noção de dúvida foi introduzida no ceticismo, o que desejamos pensar é, ao contrário, o impacto causado pelo pensamento moderno ao modo de se interpretar o ceticismo. Deste modo, o interesse de Popkin concentra-se no período conhecido como ceticismo moderno, que se costuma considerar ter início a partir de meados do século XVII, sendo Descartes o seu marco principal, ao passo que nosso interesse é no chamado "ceticismo renascentista", cujo período normalmente entende-se estender do início do século XV ao final do século XVI.

De acordo com esta perspectiva, a Apologia de Montaigne (1588) poderia representar não apenas um ponto de partida para a influência do ceticismo no período moderno, mas ao mesmo tempo um ponto de chegada do processo de transformação do ceticismo através da noção de dúvida. Pois, com Montaigne, pode-se considerar completo o processo de transformação do ceticismo através da dúvida.

Como veremos adiante, pode-se notar que, no contexto religioso, Erasmo, Lutero, e, mais explicitamente, Melanchthon já interpretam o ceticismo como uma “doutrina da dúvida", bem como nas traduções latinas de Traversari (1432) e Estienne (1562) o termo "dúvida" é utilizado para traduzir termos técnicos céticos centrais. Como a noção de dúvida é introduzida no ceticismo desde a sua redescoberta, em vista do nosso propósito de analisar a reconfiguração do ceticismo através da noção de dúvida, o período desde a recepção inicial do ceticismo até as publicações da década de 1560 parece-nos ser fundamental.

A pesquisa de Emmanuel Naya é esclarecedora ao mostrar que a recepção inicial do ceticismo entre os humanistas italianos consiste, na verdade, em uma longa história de tentativas de se compreender o ceticismo. Naya (2009, p. 20) assinala que "o século XVI primeiramente redescobriu um corpo textual 
fragmentado e disperso, um verdadeiro quebra-cabeça que seria progressivamente organizado", de modo que as condições da recepção do ceticismo no período renascentista foram "incomunmente erráticas". O esforço interpretativo do "fenômeno cético" levaria décadas para consolidar uma leitura coerente e unificada do Pirronismo, o que finalmente teria ocorrido durante a primeira metade do século XVI. No entanto, escreve Naya:

Conhecia-se Pirro a partir da década de 1470 - bem antes da década de 1560 - e as principais noções céticas a respeito da suspensão do juízo (épochè, épéchein, éphektikoi) são progressivamente esclarecidas entre 1510 e 1530. Portanto, a partir de meados do século, havia uma consistência crítica que contribuía para um corpus textual excepcionalmente rico. Durante os quinze anos seguintes, o Pirronismo receberia efetivamente uma identidade filosófica, como é demonstrado no artigo "sceptica" publicado por Robert Estienne ${ }^{55}$ em 1543. (Naya, 2009, p. 21)

Deste modo, Naya altera a cronologia comumente aceita de que o ceticismo teria penetrado na consciência moderna a partir das controvérsias da Reforma e, sobretudo com as publicações latinas de Sexto da década de 1560. Naya prossegue:

A segunda metade do século não produziu nenhuma novidade: a redescoberta essencial das noções já havia sido realizada antes, bem como a definição do corpus pirrônico: Amônios, Aulus Gellius, Laércio, Lucian, Cícero, e Sexto - cujas obras eram difíceis de encontrar, mas, no entanto notórias - constituíam o corpus essencial no século XVI (Naya, 2009, p.22).

Com esta alteração na cronologia da "via de entrada" do ceticismo na modernidade, um resultado que se pode concluir da pesquisa de Naya consiste na reabilitação do período de mais de um século do ceticismo entre os humanistas italianos como relevante para se entender o "fenômeno cético moderno", mostrando, sobretudo, que é previamente às publicações latinas quando ocorre

55 Robert Estienne, irmão mais velho de Henri, da família Stephanus. Dictionarium, sive latinae linguae thesaurus, Paris: R. Estienne, 1543. 
grande parte do esforço de organização, tradução e interpretação do ceticismo, estabelecendo as bases conceituais que se podem notar a partir de então, desde Erasmo e Lutero, à tradução de Estienne e à apresentação da tradição cética feita por Montaigne em sua Apologia de Raymond Sebond.

Deste modo, o esforço filológico de interpretação entre os humanistas precede o uso religioso que se fará do ceticismo no início do século XVI. Segundo Naya, surpreendentemente, são as enciclopédias, os dicionários, e thesauri que desempenham um papel fundamental na difusão do ceticismo, e deste modo permitem efetuar a reconstrução do seu processo de assimilação ao início do período moderno. Baseando-se na pesquisa lexicográfica de cerca de vinte famílias de dicionários entre 1470 e 1610, afirma (2009, p. 21):

A redescoberta do ceticismo consistiu primeiramente na redescoberta das principais personagens da escola pirrônica, desde a década de 1480 adiante [...] Esta popularização das personagens pirrônicas ilustres mostra que a Nova Academia não foi um elo principal na redescoberta do ceticismo entre o fim do século XV e meados do século XVI: a personagem principal permaneceu sendo Pirro, e foi sob a sua égide que elementos doutrinais foram difundidos e interpretados, até 1550, quando a importância de Pirro é diminuída em benefício de Sexto Empírico.

O ceticismo é redescoberto e interpretado em conexão com uma "personagem cética" representativa da tradição: primeiramente o conhecimento de Pirro é mais amplo, e posteriormente Sexto Empírico vem a ganhar maior notoriedade. De acordo com Naya, os principais representantes da Nova Academia, Arcesilau e Carnéades não são elos fundamentais para a redescoberta do ceticismo neste período. Contudo, se, por um lado, não se confunde as personagens principais da Nova Academia com as personagens do Pirronismo, por outro lado, os "céticos e acadêmicos" são constantemente confundidos entre si e até tomados como equivalentes.

Deste modo, não se deve pensar que a tradição neoacadêmica não desempenhe um papel importante na redescoberta do ceticismo. Schmitt (1972, p.56) assinala que, apesar dos Academica não levarem a questionamentos 
propriamente filosóficos entre os humanistas dos Quatrocentos, “ocasionalmente fazem uso de Diógenes Laércio e diversas outras fontes gregas para auxiliar a esclarecer o contexto da obra de Cícero". E, da mesma forma que a tradição pirrônica é utilizada para esclarecer o contexto dos Academica, refere-se à tradição neoacadêmica para se buscar compreender melhor a recém-descoberta filosofia cética. Desde a redescoberta do scepticus, no início do século XV, até as publicações de Sexto da década de 1560, os Academica consistem na fonte de conhecimento que estava mais acessível sobre a tradição cética grega. Inclusive a a confusão entre o scepticus e o academicus torna visível a importância da tradição neoacadêmica para o esforço de compreensão do ceticismo na época.

Quando [os pensadores renascentistas] falam dos Academici, quase sempre querem dizer "céticos", i.e., no sentido de céticos filosóficos ou epistemológicos que duvidam se o homem pode ter conhecimento certo e verdadeiro sobre o mundo (Schmitt, 1972, p. 8).

O termo "acadêmico" é utilizado durante todo o início do período moderno como sinônimo para 'cético' - ou o que na modernidade (e predominantemente até os dias atuais) se entende ser um pensador "cético". Embora o termo latino scepticus tivesse sido introduzido por Traversari desde a década de 1430, “academico" e "cético" continuariam a ser usados como sinônimos, uso que não sofreria mudanças até o século XVII (Schmitt, Floridi). Deste modo, refere-se aos "Céticos e Acadêmicos" indistintamente, como se designassem uma mesma forma de pensar que já consiste em uma referência bem conhecida - o que se pode ver no debate entre Erasmo e Lutero sobre o livre-arbítrio. Schmitt escreve a este respeito:

Alguns elementos característicos do ceticismo acadêmico, p.ex. o probabilismo e a suspensão do juízo, são amplamente discutidos durante a primeira metade do século XVI em escritos que tratam de questões religiosas da época. Além do mais, como em outros escritos que envolvem questões conceituais do mesmo período, encontra-se caracterizações frequentes do Academicus como alguém que possui 
uma moldura intelectual particular, sendo presumidamente conhecido por todos. (Schmitt, 1972, p. 59).

Em suas controvérsias religiosas, Erasmo e Lutero referem-se aos "Céticos e Acadêmicos", o que indicam ser o ceticismo bem conhecido possuir uma identidade bem definida já na década de 1520. Isto confirma a cronologia de Naya: o ceticismo e as personagens céticas são progressivamente esclarecidos desde o final do século XV, e se estabelecem como referências intelectuais no início do século XVI.

Pode-se frisar que a tradição neoacadêmica, transmitida por Cícero e Agostinho, e os Academica em particular desempenham um papel fundamental na recepção inicial do ceticismo. Mesmo após a publicação de Sexto Empírico, podese afirmar que os Academica continuam a exercer considerável influência ${ }^{56}$. Além de se misturarem à interpretação e compreensão do ceticismo pirrônico desde os anos iniciais da sua redescoberta, a tradição neoacadêmica influencia diretamente as traduções latinas das fontes pirrônicas, de modo que as traduções de Diógenes Laércio por Traversari (1432) e Sexto Empírico por Henri Estienne (1562) baseiam-se no latim de Cícero e Agostinho. Como escreve Floridi (2002, p. 14),

A terminologia cética era baseada no latim de Cícero e Agostinho, e o pirronismo chegou ao debate filosófico nos séculos XVI e XVII através do léxico técnico do ceticismo acadêmico.

Como vimos, no léxico técnico de Cícero a dúvida é um termo proeminente. Cícero cita a palavra grega epoche e oferece como tradução "retenção do assentimento" (retentio assensione). Embora a sua apresentação das questões próprias da Nova Academia se desenvolva frequentemente através das noções tradicionais de assentimento, apreensibilidade, e retenção do juízo, Cícero

56 Após as publicações de Sexto da década de 1560, os Academica voltam a exercer maior influência em meados do século XVII no contexto do cartesianismo (ver Maia Neto, 2007). 
também apropria-se desta tradição, e reinterpreta o pensamento acadêmico através da noção de dúvida (dubitari, dubio, incerta, etc.).

Não apenas a tradição neoacadêmica é utilizada como uma principal referência para se compreender e interpretar a filosofia cética desde a sua recepção inicial entre os humanistas, como também a noção de dúvida é introduzida na filosofia cética desde a sua retomada. Estes dois fenômenos são concomitantes, sendo a evidência para ambos fornecida pelas traduções das fontes textuais do início do período moderno ${ }^{57}$. Nas palavras de Vogt (2010):

Cícero é da maior importância para a transição entre o ceticismo antigo e o ceticismo do início do período moderno. Como em outras áreas da filosofia, a influência de Cícero é em parte a influência do tradutor. Ao transpor ideias filosóficas à língua de uma cultura diferente, as ideias mudam. Cícero fala às vezes de duvidar, dubitari (...). Mas a dúvida não tem lugar no ceticismo grego.

Como escreve Vogt, a influência de Cícero na retomada e interpretação do ceticismo na modernidade é em parte a influência de um tradutor. Cícero pode ser visto como um elemento fundamental de transição entre o ceticismo da Antiguidade e a sua retomada no início do período moderno. Através do seu vocabulário e da sua própria concepção filosófica, é possivel explicar em parte a introdução da noção de dúvida no ceticismo na modernidade. Contudo, deve-se ter cautela para não exagerar a influência de cícero e de seu vocabulário latino para a introdução da dúvida no ceticismo no período moderno. Segundo Paganini (2008, p. $57 \mathrm{ss})$ :

[...] tanto Cícero quanto Agostinho se servem fluentemente do verbo dubitare e de todos os seus derivados para designar a orientação característica do ceticismo, sendo a partir deles que a atividade principal do cético torna-se sinônimo de dúvida em vez da suspensão do juízo. (grifos nossos)

57 Analisaremos as traduções adiante, em 3.3. 
Estas palavras podem levar a pensar que o latim de Cícero e Agostinho seja a fonte exclusiva para a introdução da dúvida no ceticismo. Na sequencia, afirma que o Cícero tradutor:

[...] foi tão influente ao longo de todo o Renascimento, que Estienne não sente a necessidade, em seu comentário, de justificar a maneira pela qual traduzira a aporia cética.

De acordo com Paganini, Estienne teria aceitado a autoridade de Cícero para a sua interpretação e tradução dos aporetikoi como "aqueles que duvidam" (addubitant). Embora claramente seja com base no vocabulário de Cícero e Santo Agostinho que as fontes textuais pirrônicas tenham sido traduzidas no Renascimento, pode-se argumentar que a influência do Cícero tradutor não é por si só suficiente para explicar o modo como o ceticismo passaria a ser entendido no período como uma filosofia da dúvida. Portanto, partindo-se da influência do latim de Cícero e Santo Agostinho, não se deve concluir que esta seja a única via através da qual a noção de dúvida teria sido introduzida no ceticismo durante o período do Renascimento.

A introdução da dúvida no ceticismo e a sua sinonímia não parece se dever exclusivamente à ampla influência exercida por Cícero e seu vocabulário latino, e tampouco consistir em apenas uma questão linguística ou lexical. Buscaremos mostrar que tanto a influência de Cícero, quanto a de seu vocabulário latinopodem ser consideradas como apenas um dentre possivelmente diversos fatores que convergem para a introdução da dúvida no ceticismo. Buscaremos fazê-lo, no próximo capítulo, de duas maneiras diferentes:

1) Com Cícero já ocorre uma transformação na compreensão do "ceticismo" - melhor dizendo, da tradição acadêmica. Como vimos, a partir da compreensão dogmática de Filon de Larissa, Cícero reconcebe a significância do pensamento acadêmico no interior de um ecleticismo positivo, em que o sentido propriamente cético da epoche é deixado em segundo plano, passando a ser associada à 
liberdade de escolha de acordo com a doutrina do probabilismo. Cícero reinterpreta a tradição acadêmica e a apresenta ao seu modo, de acordo com os seus próprios objetivos. Deste modo, Cícero oferece uma reconcepção do pensamento neoacadêmico através do seu probabilismo eclético, na qual a dúvida desempenha um papel central Neste sentido, pode-se considerar enorme a influência da exposição da tradição acadêmica na obra de Cícero para o legado do ceticismo. Entetanto, mesmo a sua influência para a transformação do ceticismo grego no Renascimento através da noção de dúvida não se resume a uma questão linguística ou simplesmente à sua atuação como um tradutor. Cabe assinalar que a importância de Cícero e da sua concepção da filosofia acadêmica - que não se restringe aos Academica - é também filosófica.

Os Academica de Cícero não exercem influência significativa no período medieval após a época de Santo Agostinho, voltando a serem mencionados somente a partir do século XII no contexto da Escolástica (cf. Hunt, 1998 e Schmitt, 1972). Mas, por outro lado, no que diz respeito mais a aspectos sociais, culturais e econômicos do que propriamente filosóficos, e neste sentido a obra de Cícero exerce enorme influência durante o período medieval. Ao comparar a influência de Cícero à de Aristóteles no período medieval, Schmitt escreve:

A influência de Cícero durante a Idade Média foi enorme. Foi talvez tão grande quanto a de Aristóteles, embora não tenha sido enfatizada na mesma medida pelos divulgadores da cultura medieval, e os escritos de Cícero certamente não dominaram o ensino na universidade dos séculos XIII e XIV na mesma medida em que os escritos de Aristóteles. A influência de Cícero provavelmente foi sentida em um espectro mais amplo dos níveis social e econômico do que a do Estagirita. (1972, p.33)

Deste modo, é em conexão com a sua obra política, moral, oratória e retórica que se pode notar a importante e ininterrupta influência da obra de Cícero. E, neste sentido, o De Oficiis parece ser uma das suas obras mais influentes. O probabilismo eclético de Cícero pode ser caracterizado como a concepção filosófica dominante do seu pensamento, concepção que está presente ao longo de 
toda a sua obra, tanto em seus escritos filosóficos, quanto sobre retórica, oratória, moral, e política.

Cícero é tomado pelos humanistas como modelo de tradutor e eloquência em latim clássico, sendo uma referência para os humanistas no que diz respeito aos deveres cívicos, oratória e retórica. Como mostrou Quentin Skinner (2009, pp.106-110), a chave para interpretar o humanismo de Petrarca está em que, ao redescobrir o "grande gênio da Antiguidade", adota como seus os ideais ciceronianos, dentre os quais se pode destacar a união entre sabedoria e eloquência: o homem de virtude não deve apenas ser sábio, mas saber transmitir sua sabedoria aos seus ouvintes, de modo a incitá-los a ações virtuosas, e assim conferir à sua sabedoria um uso prático (cf. De Oratore). Desta maneira, o estudo da retórica de modo algum seria menos valioso do que o estudo da filosofia moral para a formação. Neste sentido, é mais plausível que o interesse de Petrarca por Cícero - e inclusive o seu interesse em recuperar os Academica - tivesse como foco o contexto da retórica e oratória, e não a temática cética. E, com efeito, a própria filosofia acadêmica de Cícero está diretamente ligada não somente ao que se poderia chamar de "questões céticas", mas figura em sua obra em conexão a diversas outras discussões. Cícero afirma nas Tusculanas:

Sempre me agradou o hábito dos peripatéticos e dos acadêmicos de discutir, de todos os problemas, o pró e o contra: não só porque esse sistema é o único apto para descobrir em qualquer situação o elemento de verossimilhança, mas também pelo ótimo exercício que isso constitui para a palavra. (Tusc. Disput., II, 3, 9, citado em Reale, 2011, p. 200)

A argumentação in utramque partem, que constitui um dos pilares do seu probabilismo, incide diretamente sobre a arte da retórica e da oratória. Com efeito, referindo-se a Carnéades em De Oratore (III, 80), Cícero afirma que a capacidade de argumentar em ambos os lados de uma questão em todos os casos [de omnibus rebus in utramque partem sententiam possit dicere], aliada à experiência e à prática constituem as qualidades do "verdadeiro e único orador perfeito". Desde a 
década de 80 a. C., Cícero se declara um seguidor dos acadêmicos (Inv. II, 9-10), e expõe a sua doutrina probabilista "acadêmica" em diversos escritos, como $D e$ oficciis, Tusculanae Disputationes, De Invectione, e desempenha um papel central em De natura deorum. Deste modo, o probabilismo de Cícero - bem como a confusão deste com o pensamento "cético" da Nova Academia - pode ser considerado atuante em diversas áreas de influência, de modo que possui um legado histórico para além dos diálogos dos Academica, de questões relativas à tradição cética, e da própria filosofia.

2 ) Pode-se afirmar que as traduções latinas de Sexto têm como pano de fundo outra visão de mundo e, mais especificamente, outro modelo de conhecimento, que é diferente tanto do ceticismo grego, quanto do probabilismo eclético de Cícero. No início do período moderno, a noção de dúvida já está presente e é relevante entre os humanistas como um conceito filosófico, o que se pode notar desde o contexto da escolástica medieval. É possível afirmar que o processo de elaboração filosófica da noção de dúvida e a sua introdução no pensamento moderno remontam às preocupações próprias do período, e ao seu contexto específico, às questões e interesses vigentes na época.

Em seus comentários aos Academica, os humanistas já fazem uso da noção de dúvida para interpretar seus principais temas e questões. Contudo, tendo em vista que Cícero insere o conceito de dúvida em sua apresentação da tradição acadêmica e em sua concepção particular da filosofia acadêmica, isto talvez pudesse ser considerado natural, e não indicar nada a respeito do pensamento humanista propriamente dito ${ }^{58}$. Portanto, é relevante que se possa notar tanto nos pensadores escolásticos quanto nos humanistas o uso filosófico das noções de dúvida e certeza em conexão a diversos temas e contextos, sem relação direta com a tradição acadêmica ou com os Academica em particular.

58 Bartolomeu della Seta, por exemplo, cita a passagem dos Academica em que Cícero descreve a maiêutica socrática como um exercício da dúvida. 


\section{A apropriação da dúvida pelo pensamento filosófico}

Nosso objetivo neste capítulo é examinar alguns dos caminhos pelos quais a noção de dúvida, ausente no ceticismo pirrônico e na filosofia grega antiga de um modo geral, vem a ser primeiramente tomada como um conceito filosóficamente relevante, vindo então a ser amplamente apropriada pelo pensamento filosófico, e até tornar-se um conceito central para a filosofia.

Desta maneira, desejamos examinar alguns caminhos do processo histórico que culmina com a apropriação da noção de dúvida à "consciência moderna". Iniciamos com o que pode ser considerado um dos primeiros passos deste processo: a apropriação da noção de dúvida, termo originariamente de uso comum, pelo pensamento filosófico de Cícero. Passamos, em seguida, ao contexto da Escolástica e do humanismo italiano. Com isso, pretendemos apenas oferecer alguns exemplos de vias pelas quais ocorreu esta apropriação conceitual.

Claramente, deixamos de lado importantes passos da longa história da apropriação filosófica da noção de dúvida, como o contexto da Patrística grega e latina - e o famoso uso de Santo Agostinho do conceito de dúvida, especialmente em De Trinitate, bem como o próprio contexto histórico do início do período moderno. Portanto, buscamos apenas tratar de alguns elementos que possam contribuir para a compreensão do grande destaque que a noção de dúvida viria a assumir no pensamento moderno - e, em particular, na releitura do ceticismo antigo no Renascimento. 


\section{1}

\section{O uso filosófico da dúvida nos Academica de Cícero}

Cícero (106-44 a.C.) estuda com diversos filósofos durante a sua vida, tanto em Atenas quanto em Roma. Em De natura deorum $(I, 3)$ revela sua "intimidade com aqueles homens muito eruditos que frequentaram minha casa e conversavam diariamente comigo, em particular Diodoro, Filo, Antíoco e Posidônio". No período em que reside em Atenas (88-84 a.C.) frequenta tanto a Stoa Poikilé, quanto a Academia de Platão, então sob a liderança (c.110-79) de Filo de Larissa. A concepção de filosofia neoacadêmica que Cícero endossa tem a sua inspiração neste filósofo. Em sua exposição da tradição acadêmica, Cícero refere-se duas vezes a uma obra de Fílon (Acad., I, 13; II, 11), bem como a duas obras de Clitômaco (Acad., II, 98, 103), hoje perdidas.

Cícero escreve grande parte das suas obras filosóficas após o seu exílio político (58 a. C.). Com elas, deseja criar uma "cultura filosófica" entre os romanos. No início dos Academica (c. 45 a. C.), Cícero pergunta a Varro por que não se dedica à exposição da filosofia. Varro responde ser impossível compreendê-la sem erudição grega; quem conhece grego estudará filosofia em grego, e quem não conhece o grego, tampouco irá se interessar por estudá-la em latim. Logo, traduzir a filosofia grega para o latim seria "um esforço vão" (Acad., I, 6). Eis a réplica de Cícero (Acad. I, 10):

Na verdade, tanto quem não pode ler os livros gregos lerá estes; quanto quem pode ler o grego não deixará de lado os trabalhos da sua própria nação. Quão maior prazer não terão dos filósofos, se estes imitarem Platão, Aristóteles e Teofrasto da mesma maneira que aqueles poetas que imitaram Ésquilo, Sófocles e Eurípedes?

Em muitas das suas obras, Cícero justifica tanto o esforço de tradução da filosofia grega para a língua latina, quanto o valor da própria filosofia e do seu estudo, pois seria o melhor ou mesmo o único caminho para se buscar a sabedoria. De acordo com a sua própria avaliação, o mérito do seu trabalho seria 
essencialmente o de transmissão: apenas traduziria para o latim algum manual que lhe estivesse disponível, situando os argumentos em forma de diálogos em cenário romano e lhes fornecendo exemplos retirados da história romana. No entanto, pode-se notar que a apresentação de Cícero da filosofia grega não carece de originalidade. Ao deslocar a filosofia grega para a cultura romana, ocorrem diversas apropriações e inflexões, podendo-se notar uma diferença profunda entre o pensamento filosófico de Cícero e a filosofia helenística. Este é o caso da tradição da Nova Academia que Cícero expõe em seus Academica. Nosso objetivo é apontar para um aspecto em que a exposição de Cícero é original, aspecto para o qual até agora não foi dada suficiente atenção.

\section{O probabilismo eclético de Cícero}

Cícero afirma em diversas das suas obras ser "acadêmico", de modo que apresenta o seu pensamento como representativo da filosofia da Academia. Para o filósofo romano, Arcesilau teria reavivado o espírito da velha Academia de Platão, de modo que, para ele, a Nova Academia, inaugurada por Arcesilau, estaria em consonância e continuidade com a mais antiga. É neste sentido que afirma ser simplesmente "acadêmico": como haveria apenas uma tradição acadêmica, Cícero entende-se partidário da Academia representada desde Sócrates, Platão, e continuada por Arcesilau e Carnéades. Em Acad. I, 13, ao ser interpelado por Varro sobre ter abandonado a velha Academia e estar seguindo a Nova, Cícero afirma, baseando-se na autoridade de Filo, que "não há duas Academias".

No entanto, o pensamento acadêmico defendido por Cícero está bastante afastado do pensamento de Arcesilau e Carnéades. Além de esposar a concepção do pensamento acadêmico desenvolvido por Filo em uma doutrina positiva, em muito distante das atitudes filosóficas de Arcesilau e Carnéades, o pensamento de Cícero é marcado ainda pelo seu próprio ecletismo. Cícero concilia vários

elementos do pensamento clássico e helenístico; platônicos, aristotélicos e estoicos à sua própria postura intelectual, cuja natureza pode ser considerada 
essencialmente prática, marcada pela sua vivência de advogado, orador, e político romano. O caráter próprio do pensamento "acadêmico" de Cícero pode ser descrito como um "probabilismo eclético"59. Nas Tusculanas, Cícero escreve:

Há liberdade de pensamento, e cada um pode sustentar o que quiser, quanto a mim, atermeei ao meu princípio, e buscarei sempre em todas as questões a máxima probabilidade, sem estar ligado à lei de nenhuma escola particular à qual deva forçosamente seguir na minha especulação . "Sed defendat, quod quisque sentit; sunt enim iudicia libera: nos institutum tenebimus nullisque unius disciplinae legibus adstricti, quibus in philosophia necessario pareamus, quid sit in quaque re maxime probabile, semper requiremus" (Tusc. disput., IV, 4, 7).

O princípio ou método de Cícero consiste em buscar a máxima probabilidade, sem estar ligado à doutrina de nenhuma escola em particular. Cícero julga que sustentar uma doutrina específica significaria a imposição de limites em sua capacidade de investigar e escolher o mais provável. Para o pensador romano, manter desimpedida a sua liberdade de pensamento depende diretamente de não "estar ligado à lei de nenhuma escola", e deste modo seria possível, em todos os casos, buscar a "máxima probabilidade". Glucker (1996) assinala que o ecletismo de Cícero não deve ser confundido com uma doutrina fixa. Não trata-se de agrupar diferentes teorias, de diversas procedências em um corpo doutrinário, sistemático e fechado em si mesmo, mas de ser livre para escolher a teoria ou argumento que lhe possa parecer, a cada momento, ser a mais provável. O ecletismo de Cícero, em vez de doutrinário, seria "dia após dia": não apenas não se compromete com a procedência das teorias, mas não se compromete inclusive com a sua própria escolha: em outro momento, pode deixar de lado o que anteriormente havia escolhido como o mais provável.

Se o ecletismo é para Cícero o melhor modo de manter-se livre e desimpedido para buscar o mais provável, o método ou procedimento mais eficaz para se fazê-lo é através da argumentação in utramque partem. Em De officiis (II, 2, 8) Cícero escreve: "Não se pode ter uma visão clara do que é provável, a não

59 Ver Giovanni Reale (2011), parte II, cap. IV. 
ser que se faça uma comparação dos argumentos de ambos os lados" (probabile elucere non posset, nisi ex utraque parte causarum facta contentio). Argumentar em ambos os lados é o procedimento que deve ser adotado pelo probabilismo, pois consiste no melhor caminho para que se possa "ter uma visão clara do que é provável”. Cícero afirma nos Academica (II, 7):

O único objetivo da nossa discussão é, ao argumentar em ambos os lados (in utramque partem), extrair e dar forma a algum resultado que possa ou ser verdadeiro ou o mais próximo possível da verdade. neque nostrae disputationes quicquam aliud agunt nisi ut in utramque partem dicendo eliciant et tamquam exprimant aliquid, quod aut verum sit aut ad id quam proxime accedat.

Nota-se que o objetivo de argumentar em ambos os lados é encontrar o que mais se aproxima da verdade, não a suspensão do juízo. De acordo com Reale, a argumentação pró e contra para Cícero "não deve levar à suspensão do juízo, mas ao encontro do provável e do verossímil [:] oferece-lhe a possibilidade de escolher a solução mais provável" (Reale, 2011, p. 200). Deste modo, a epoche não é uma consequencia da argumentação in utramque partem. Portanto, a noção cética de epoche parece ser dispensável para Cícero, tornando-se supérflua, obsoleta. Em discutir a questão do sumo bem (se a virtude é suficiente para a felicidade), Cícero conclui (Acad. II, 134):

Sou arrastado em diferentes direções - agora a última posição parece-me ser a mais provável, agora a primeira. Contudo, ainda creio que a não ser que uma ou outra seja verdadeira, a virtude é destruída [...] "Distrahor - tum hoc mihi probabilius tum illud videtur. Et tamen, nisi alterutrum sit, virtutem iacere plane puto"

Não obstante ser "arrastado em diferentes direções”, Cícero acredita que um dos lados deve ser o mais próximo da verdade. A epoche não parece ser uma possibilidade real para Cícero - como seria possível simplesmente suspender o juízo sobre a virtude e a felicidade? Parece ser esta possibilidade, a que ocasionaria a epoche; o equivalente da destruição da virtude - para Cícero, a 
verdade ou verosimilhança tem de estar em um dos lados: um ou outro tem que ser verdadeiro. A equipolência, portanto, não arrasta Cícero para a epoche. Como é assinalado por Bicca (2009, p. 82),

[...] não obstante suas preferências céticas, Cícero não exibe em seus diálogos nenhuma construção argumentativa que desague em suspensão explícita; na melhor das hipóteses, enxerga-se uma esboçada e sugerida equipolência, que não exibe nenhum próximo passo em termos de método.

Cícero não pensa a argumentação in utramque partem em conexão com a epoche. Argumentar em ambos os lados não tem em vista a epoche, e sim a busca do provável. E, inversamente, ao se deparar com uma equipolência, Cícero não a entende como índice para a epoche, mas como situação-limite em que nenhuma probabilidade parece ser possivel.

Deve-se lembrar que a generalização da epoche proposta por Arcesilau é considerada uma inovação do seu pensamento, o que leva inclusive à consideração de que inaugura uma nova fase da Academia (D.L. IV, 28). A Média ou Nova Academia é caracterizada pela epoche, sendo os seus seguidores conhecidos como ephetikos, "aqueles que suspendem o juízo sobre tudo"60. Dessa maneira, a noção de epoche desempenha um papel central no pensamento de Arcesilau, caracterizando um novo modo de filosofar que inaugura uma nova fase da Academia, em que a suspensão (epoche) é tomada como um índice de sabedoria. A primeira referência à epoche nos Academica (II, 59) ocorre ao final do discurso de Lucullus, porta voz para Antíoco de Ascalon:

Em primeiro lugar, quem pode estar desimpedido quando não há diferença entre apresentações falsas e verdadeiras? Segundo, que critério existe para uma apresentação verdadeira, se um critério pertence tanto a uma apresentação verdadeira quanto a uma falsa? Estas considerações necessariamente levaram à doutrina da epoche, que é uma retenção do assentimento (adsensionis retentio), na

${ }^{60}$ Plutarco, Contra Colotes, 1120C. Cf. Long \& Sedley, 1987, p. 440. 
qual Arcesilau foi mais consistente, se as opiniões que algumas pessoas sustentam sobre Carnéades forem verdadeiras. "Primum qui potestis non impediri, cum a veris falsa non distent? deinde quod iudicium est veri, cum sit commune falsi? Ex

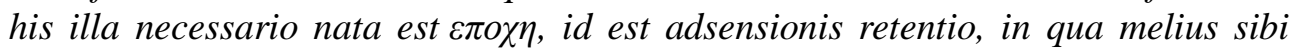
constitit Arcesilas, si vera sunt quae de Carneade non nulli existimant".

Cícero oferece como tradução para epoche a expressão "retenção do assentimento"61, e interpreta as dificuldades cujas considerações levariam à suspensão como impedimentos para o pensamento. Contudo, Cícero não entende que estes impedimentos realmente restrinjam a capacidade de afirmar um juízo. Os "impedimentos" que para Arcesilau levavam à epoche, para Cícero poderiam ser contornados. Como vimos acima, de modo a dirimir as dificuldades que levariam à epoche, o procedimento a ser adotado consiste na argumentação pró e contra (in utramque partem disserere). Pode-se perguntar, portanto: a noção de epoche desempenha alguma função no pensamento acadêmico de Cícero?

Cícero endossa a tese de que a verdade existe, mas é inapreensível (Acad. II, 67-68, 77-78, 110, 141). Embora a verdade não possa ser apreendida, Cícero sustenta que para se considerar algo como provável não é preciso “conferir o assentimento, aprovar, tomar o fato como certo, compreender, perceber, ratificar, firmar e fixar" (Acad. II, 141, cf. II, 99); uma impressão (videatur) já seria o suficiente. Deste modo, em princípio Cícero aceita os argumentos acadêmicos para a acatalepsia e, consequentemente, para a epoche. No entanto, em vez da suspensão, Cícero busca o provável. A probabilidade não seria uma forma de apreensão ou assentimento, mas a alternativa possível tendo em vista a ausência da apreensão. Sendo a verdade inapreensível, entende-se a probabilidade justamente como a busca do que mais se aproxima ou se assemelha à verdade. Deste modo, nota-se como o probabilismo de Cícero é fundado na afirmação da inapreensibilidade. “...Enquanto você [Luculo] fala de coisas 'percebidas' e 'apreendidas', nós descrevemos as mesmas coisas como 'aparecendo' (sed ea

\footnotetext{
${ }^{61}$ Há uma variação do predicado da retenção nas duas famílias de manuscritos do Academicus Primus: "retentio assensione" e "retentio assertione" que Hunt (1998) identifica, respectivamente, com as tradições italiana e francesa da obra.
} 
quae vos percipi comprehendique, eadem nos, si modo probabilia sint, videri dicimus)" (Acad. II, 105). A inapreensibilidade não leva à epoche, mas ao falibilismo de se afirmar apenas que algo é provável ou verossímil, mas não "apreendido" ou dotado de certeza. Nota-se que, além da inapreensibilidade não ser índice de epoche, mas apenas de uma nova atitude de abrir mão da certeza e buscar o provável, em sua afirmação da inapreensibilidade Cícero sustenta-se em uma teoria epistêmica limitacionista. Em De natura deorum, I, 5, 12 escreve:

\begin{abstract}
Não somos dos que negam em absoluto a existência da verdade, limitamo-nos a sustentar que a cada verdade está unido algo que não é verdadeiro, mas tão semelhante a ela, de modo que ela não pode nos oferecer qualquer sinal distintivo que nos permita formular um juízo e dar nosso assentimento. Daí deriva a existência de muitos conhecimentos prováveis que, mesmo não sendo plenamente certificados, mostram-nos tão nobre e elevados a ponto de poderem servir como guia para o sábio. "Non enim sumus ii quibus nihil verum esse videatur, sed ii qui omnibus veris falsa quaedam adiuncta esse dicamus tanta similitudine, ut in iis nulla insit certa iudicandi et adsentiendi nota. Ex quo exsistit et illud multa esse probabilia, quae, quamquam non perciperentur, tamen, quia visum quendam haberent insignem et inlustrem, his sapientis vita regeretur".
\end{abstract}

De acordo com Cícero, a verdade existe, mas está obstruída para nós, de modo que não podemos possuí-la por inteiro - o intelecto não é capaz de penetrála em sua profundidade. Devemos nos limitar a tentar nos aproximar o máximo possível da verdade através da probabilidade. Portanto, não se limita a mostrar que o verdadeiro e o falso são indiscerníveis, mas revela-se mais assertivo no tocante ao nosso bloqueio à verdade, ao ponto de considerar como "fato o mais certo possível que [...] não há diferença entre aparências falsas e verdadeiras" (Acad. II, 90). Após apresentar a enorme divergência de opiniões da tradição filosófica a respeito de alguns dos seus temas mais caros (como a questão da alma, do corpo, da physis), Cícero afirma:

Todas estas coisas estão ocultas, encobertas e circunscritas por uma densa nuvem de escuridão, de modo que o intelecto humano não possui a visão suficiente para ser capaz de penetrar os céus e atingir o interior da terra. "Latent ista omnia, 
Luculle, crassis occultata et circumfusa tenebris, ut nulla acies humani ingeni tanta sit, quae penetrare in caelum, terram intrare possit” (Acad. II, 122).

A afirmação da inapreensibilidade não ocorre após argumentar contra teses dogmáticas ou opor teses contrárias e pesar seus argumentos, mas a partir de uma reflexão sobre o desacordo (discrepantia, dissensio) entre as diversas filosofias, Cícero conclui que diante da dificuldade inerente às coisas, e da fraqueza do nosso próprio intelecto é preciso reconhecer que a verdade derradeira encontra-se obstruída para nós. A inapreensibilidade, ao que parece, é o que explica o descacordo, sendo mais fundamental: para evitar o infindável desacordo filosófico, devemos manter para nossos resultados o estatuto do que é verossímil e provável, e não absolutamente verdadeiro. No entanto, a respeito de questões de "suprema magnitude e extrema obscuridade" (Acad. II, 127) - tais como o bem supremo (cf. Acad. II, 134), os "constituentes do universo", a natureza do corpo e da alma - não é possível encontrar nenhuma probabilidade. A respeito da questão da imortalidade da alma, cícero escreve:

Tantos argumentos são oferecidos de ambos os lados. Uma parte destas questões parece ao seu homem sábio serem certas, mas o nosso não faz ideia nem do que seria mais provável, tal a extensão em que a maioria destas questões contém razões iguais para teorias contrárias. "nam utramque in partem multa dicuntur. Horum aliquid vestro sapienti certum videtur, nostro ne quid maxime quidem probabile sit occurrit: ita sunt in plerisque contrariarum rationum paria momenta." (Acad. II, 124).

Seria esta uma ocasião para a epoche? À primeira vista, este seria uma ocasião clara em que a noção cética de epoche teria efeito. No entanto, Cícero não apresenta estes casos como ocasiões para a epoche - e sequer menciona o termo -, mas que constituem limites para o probabilismo, em que a obscuridade da coisas não permite o encontro de nenhuma probabilidade, sendo inócuo, nestes casos, o uso da argumentação in utramque partem. Como Cícero afirma: "em coisas incertas não há nada provável (In incertis enim nihil probabile est)" (Acad. II, 
110). Questões de "suprema magnitude e extrema obscuridade" não oferecem ocasião para a busca do mais provável.

Portanto, parece ser o probabilismo de Cícero o que torna a epoche obsoleta em seu modo de pensar. A busca da "máxima probabilidade" situa-se entre o assentimento e a obscuridade das coisas - o provável transita no feixe entre os dois limites, de um lado, a posse da certeza, em que se julga apreender, compreender a verdade, e de outro lado, a obscuridade intransponível das coisas, em que tudo é incerto, e portanto teses contrárias contêm o mesmo grau de

probabilidade. É curioso que aquilo que configuraria uma ocasião típica em que o cético classico suspenderia o juízo, Cícero, no entanto, não indica como ocasião para a retentio assensionis, mas como um limite para a afirmação do provável.

Além de não entender a epoche como o que seria próprio dos Acadêmicos, (como o era com Arcesilau), é interessante notar que Cícero tampouco apresenta o probabilismo como a diferença específica entre os modos acadêmico e dogmático de filosofar. Esta diferença diria respeito, antes, a atitudes diferentes em relação à filosofia e à sabedoria, podendo-se considerar o probabilismo como uma consequencia da atitude própria dos acadêmicos face ao conhecimento. Qual seria esta atitude: se nem a epoche, nem o probabilismo, o que Cícero sustenta como sendo a característica distintiva dos academicos?

\section{O papel da dúvida em Cícero}

O homem sábio, em decorrência da inapreensibilidade das coisas, deve suspender o juízo a respeito de tudo, de modo a não opinar. Esta é a generalização de Arcesilau da tese estóica de que o homem sábio não opina. Cícero, no entanto, não endossa a concepção de homem sábio, revelando sua distância do contexto da Nova Academia de Arcesilau e Carnéades, tradição por ele próprio transmitida. 
Tendo em vista a exigência, atribuída a Antíoco, de uma representação de tal maneira que não possa haver uma falsa da mesma maneira, Cícero afirma:

Não encontro nenhuma tal representação, e por consequência sem dúvida irei conferir o meu assentimento a algo que não é realmente conhecido, i.e., devo sustentar uma opinião. "Nihil eius modo invenio. Itaque incognito nimirum adsentiar, id est, opinabor". (Acad. II, 113)

Na mesma medida que rejeita a concepção de homem sábio, sustentar uma opinião deixa de ser problemático para Cícero. Logo no início do seu discurso no Luculo afirma: "sou um grande opinador (pois não sou um homem sábio)" (Acad. II, 66). Ao mesmo tempo em que expõe o pensamento da Nova Academia, afastase das exigências compartilhadas por Zenão e Arcesilau para o homem sábio, insistindo várias vezes não ser ele próprio um homem sábio (cf. Acad. II, 115). Se Cícero rejeita a concepção de homem sábio, e afirma que sustenta opiniões, de que modo entende a sabedoria?

\begin{abstract}
Assim como outras escolas mantêm que algumas coisas são certas, outras incertas, nós, divergindo delas, dizemos que algumas coisas são prováveis, outras improváveis. O que, portanto, me impede de aceitar o que me parece provável, e rejeitar o que me parece improvável, e assim fugir, evitando a presunção de nítidas afirmações, à temeridade, que está muito longe da sabedoria? "Nos autem, ut ceteri alia certa, alia incerta esse dicunt, sic ab his dissentientes alia probabilia, contra alia dicimus. Quid est igitur, quod me impediat ea, quae probabilia mihi videantur, sequi, quae contra, improbare atque affirmandi arrogantiam vitantem fugere temeritatem, quae a sapientia dissidet plurimum?" (Cícero, De officiis, II, 2, 7-8).
\end{abstract}

A presunção e a temeridade estão o mais distante possível da sabedoria. Devemos sim opinar, mas sabendo que o que sustentamos não é toda a verdade, mas uma aproximação provável. A característica específica da filosofia acadêmica para Cícero consiste em abrir mão da exigência dogmática de se estar na posse da verdade e da certeza. Observar e contentar-se com probabilidades é uma forma de evitar a presunção de sustentar afirmações positivas da verdade. Como a verdade 
absoluta está bloqueada para nós, devemos buscar a rota alternativa da verossimilhança e probabilidade, que transitam entre a certeza absoluta e a total incerteza. É dessa forma que o pensamento acadêmico seria representativo de modéstia e de humildade intelectual, e apontaria para outro caminho possível para a filosofia. Eis a descrição de Cícero do tipo de filosofia que rejeita:

A filosofia deve avançar por argumentos. Como encontrará êxito? E o que acontecerá com a sabedoria? É o seu dever não duvidar de si mesma ou de suas doutrinas, que os filósofos denominam dogmata, qualquer um deles seria um crime abandonar; pois a entrega a tal doutrina é uma traição da lei moral, e este pecado é a fonte comum das traições de amigos e contra a pátria. "Ipsa autem philosophia, quae rationibus progredi debet, quem habebit exitum? Sapientiae vero quid futurum est? quae neque de se ipsa dubitare debet neque de suis decretis, quae philosophi vocant $\delta$ o $\mu \alpha \tau \alpha$, quorum nullum sine scelere prodi poterit. Cum enim decretum proditur, lex veri rectique proditur, quo e vitio et amicitiarum proditiones et rerum publicarum nasci solent". (Acad., II, 27)

A exigência dogmática para a filosofia, e consequentemente para a sabedoria é interpretada por Cícero como a imposição de que não se duvide de si, dos seus preceitos e doutrinas estabelecidas. Deste modo, nota-se que para Cícero a capacidade de duvidar de si exerce a função de critério de demarcação, sendo o que distingue entre as filosofias acadêmica e dogmática. A concepção dogmática de sabedoria exige que o pensador não duvide de si mesmo, e, nesta medida, abra mão da sua liberdade para pensar. Daí a exortação de Cícero em Acad. II, 120: "Quão valiosa a mera liberdade que é não estar submetido à mesma exigência que você!'” Em outras palavras: quão valiosa é a liberdade de não estar submetido à exigência da filosofia dogmática de sustentar peremptoriamente uma doutrina, sem jamais colocá-la em dúvida. Deste modo, ao dogmatismo Cícero opõe a capacidade de "duvidar de si", capacidade que representa uma liberdade do pensamento. É ao descrever a diferença entre o seu modo de filosofar e o modo dogmático, no início do Lucullus, em Acad., II, 7-8, que Cícero primeiramente introduz a noção de dúvida como um termo semi-técnico: 
Nem há nenhuma diferença entre nós e aqueles que pensam que possuem conhecimentos positivos, exceto que eles não têm nenhuma dúvida de que os seus princípios sejam verdadeiros, ao passo que nós sustentamos muitas doutrinas como prováveis, as quais podemos facilmente colocar em prática, mas raramente podemos levar adiante como certas: e, no entanto somos mais livres, na medida em que possuímos nosso poder de julgamento desimpedido, e não estamos limitados por nenhuma compulsão a endossar todos os dogmas que são estabelecidos para nós quase como éditos por certos mestres. "Nec inter nos et eos, qui se scire arbitrantur, quicquam interest, nisi quod illi non dubitant quin ea vera sint, quae defendunt: nos probabilia multa habemus, quae sequi facile, adfirmare vix possumus. Hoc autem liberiores et solutiores sumus, quod integra nobis est iudicandi potestas, nec ut omnia, quae praescripta et quasi imperata sint, defendamus necessitate ulla cogimur”. (Acad., II, 8)

A única diferença entre acadêmicos e dogmáticos é que estes não duvidam dos seus princípios, e os afirmam inconstestadamente como verdadeiros, ao passo que os acadêmicos sustentam suas "doutrinas" apenas como prováveis. A capacidade de duvidar de si representa uma liberdade do pensamento na medida em que deixa o intelecto desimpedido de preceitos e doutrinas, dispondo integralmente da sua capacidade de buscar e julgar a verdade.

Neste sentido, percebe-se que a noção de dúvida exerce uma dupla função no pensamento de Cícero. "Ser capaz de duvidar" relaciona-se tanto com o ecletismo, pois duvidar de si significa estar livre do endosso doutrinário a uma escola particular, e, portanto, "desimpedido" para pensar, quanto com o probabilismo: sendo capazes de duvidar de si mesmos, os acadêmicos sustentam que não se pode conhecer com certeza (adfirmare vix possumus); não negam o conhecimento, mas buscam se aproximar o máximo possível da verdade através da probabilidade. Assim, a "integridade intelectual" acadêmica consistiria na capacidade de duvidar das suas próprias opiniões, ou seja, evitar adotá-las como doutrinas e não considerá-las como afirmações peremptórias da verdade.

Portanto, Cícero apresenta a noção de dúvida em estreita conexão com a sua doutrina do "probabilismo eclético". é através da capacidade de "duvidar de si” que Cícero distingue-se dos filósofos dogmáticos; ou daqueles que afirmam as suas doutrinas como certas.. Pode-se mesmo pensar que a noção de dúvida seria, de certo modo, "anterior" ao probabilismo, ou estaria na "raiz" do "probabilismo 
eclético". A dúvida parece representar uma atitude, uma capacidade fundamental, sendo a capacidade de "duvidar de si" o que primeiramente torna o pensamento humilde, íntegro, desimpedido, logo, capaz de abrir mão da certeza e da infalibilidade, contentando-se com probabilidades, e nesta medida evitar a temeridade e a presunção.

Deste modo, pode-se afirmar que a noção de dúvida desempenha um papel central em seu pensamento. E, neste sentido, é legítimo considerar que esta noção de dúvida apresentada por Cícero desempenha o que em Arcesilau e Carnéades era desempenhado pela epoche. "Duvidar de si" - e não propriamente a retenção do assentimento ou epoche - é, em última análise, a capacidade através da qual Cícero expõe as qualidades que determinam o seu modo próprio de pensar, capacidade que confere a modéstia, humildade, liberdade e integridade ao seu intelecto. Ou seja, com a noção de dúvida Cícero expressa a sua própria convicção filosófica e, como se entende pertencer à escola dos "acadêmicos" (à "única" Academia), em determinados momentos atribui o exercício da capacidade de duvidar ao modo próprio de filosofar dos "acadêmicos" em geral.

É certamente algo curioso que, para Cícero, seja a capacidade de "duvidar de si" a característica distintiva do pensamento acadêmico e, com efeito, de toda a tradição acadêmica. No início dos Academica Posteriora, Cícero já havia interpretado a maiêutica socrática através da noção de dúvida. Após afirmar que tanto os peripatéticos quanto a tradição acadêmica retiraram amplos recursos da fonte de Platão, Varro comenta que, não obstante,

[Abandonaram] o famoso costume socrático de duvidar de todas as coisas, sem a admissão de qualquer declaração positiva. "illam autem Socraticam dubitationem de omnibus rebus et nulla adfirmatione adhibita consuetudinem disserendi reliquerunt" (Acad., I, 17).

E, novamente, no discurso de Varro no Luculo, afirma: "Sócrates duvida de todas as coisas" (Acad. II, 74-75). Nota-se que, além de recorrer à noção de dúvida para explicitar e defeder o pensamento acadêmico, o conceito de dúvida 
assume uma função técnica nos Academica, retrojetando até Sócrates o uso da dúvida como a atividade fundamental da sua prática filosófica.

Cícero apropria-se em seus escritos do termo dubitare, próprio da linguagem comum, conferindo-lhe um novo significado filosófico. Enquanto termo da linguagem comum, a dúvida costuma significar vacilação, hesitação e indecisão, e assim indicar a falta de convicção e a possibilidade do erro. Estes são os significados mais comuns do conceito de dúvida. De acordo com o uso filosófico que Cícero atribui ao conceito, a capacidade de duvidar marca a liberdade do pensamento, uma abertura fundamental ou fundacional para o encontro da máxima probabilidade. Em vez de designar vacilação, indecisão, e apontar para a possibilidade do erro, em seu sentido filosófico ciceroniano a dúvida atrela-se à liberdade e à sabedoria, à humildade e integridade do intelecto. A capacidade de "duvidar de si" passa a designar a característica distintiva dos acadêmicos, capacidade que lhes torna tanto livres quanto humildes, em oposição à adesão doutrinária e à presunção dos filósofos dogmáticos. Deste modo, Cícero pode ser considerado o primeiro pensador a fazer um uso filosófico do binômio "dúvida e dogmatismo".

Deste modo, depreende-se da obra de Cícero um uso semitécnico do termo dubitare, a partir da qual se torna possível considerá-lo um conceito relevante para o pensamento filosófico. Esta pode ser considerada uma contribuição original de Cícero em sua exposição da filosofia acadêmica. Na filosofia grega antiga, não se encontra um uso fílosófico do termo “dúvida". Não se podem encontrar os diversos vocábulos gregos que expressam o conceito de dúvida (tais como distázo, endoiázo, diakrino, dentre outros) nas obras de Platão, Aristóteles, ou Sexto Empírico com um sentido filosófico especial: a dúvida não é um conceito sobre o qual se constróem teorias ou a partir do qual são derivadas consequencias filosóficas.

A obra de Sexto Empírico (c. sec. II d. C.) e os Academica de Cícero são as principais fontes para o conhecimento do ceticismo antigo. As Hipotiposes Pirrônicas de Sexto viriam a ser redescobertas somente no século XV, e 
publicadas em latim no século seguinte. Desde Santo Agostinho até o início do século XV (quando o artigo "Pirro" de Diógenes Laércio é publicado por Ambrigio Traversari), os Academica permanecem como a fonte praticamente exclusiva da tradição cética antiga (cf. Schmitt, 1972). No século XVII, os Academica viriam a exercer renovada influência, com o pensamento de Mersenne, Gassendi, Bayle, e notoriamente Hume, dentre outros. Portanto, é possível considerar o pensamento filosófico de Cícero uma das fontes principais da apropriação não apenas do vocabulário, mas do conceito de dúvida ao pensamento filosófico, bem como para a introdução da dúvida no significado do ceticismo no período moderno, a partir da qual se consolida a interpretação de que o ceticismo seria uma "filosofia da dúvida".

É preciso, no entanto, não confundir o uso filosófico que Cícero faz da noção de dúvida, e o significado específico que lhe atribui com a concepção moderna de dúvida, segundo a qual o cético é quem "duvida de tudo". Nota-se que esta concepção de uma "dúvida ativa" está ausente da exposição de Cícero, que jamais faz uso de expressões como "é preciso duvidar de tudo" ou "tudo é duvidoso" (mas podemos imaginar que dissesse: "é preciso ser capaz de duvidar de si mesmo"). Ao contrário da dúvida moderna, nos Academica a capacidade de duvidar não expressa nenhuma radicalidade, mas serve uma função moderadora para o dogmatismo: resguardar a humildade e liberdade para pensar o perigo envolvido no endosso doutrinário a opiniões filosóficas. 


\section{2}

O pensamento escolástico

Nesta seção, desejamos mostrar que o conceito de dúvida recebe uma relevância especial no pensamento ocidental durante o período da escolástica medieval. Dominik Perler identifica quatro grupos de "questões céticas" em debates escolásticos entre 1267 e 1377 :

1) Dúvidas sobre a possibilidade de um conhecimento natural absolutamente certo;

2) Dúvidas gerais sobre a certeza absoluta;

3) Dúvidas a respeito do conhecimento por intuição;

4) Dúvidas a respeito do conhecimento demonstrativo ${ }^{62}$.

Costuma-se identificar a presença de questões céticas na escolástica, mas pode-se notar que tais questões céticas são expressas através do vocabulário da dúvida pelos pensadores da época.

Da mesma forma, costuma-se assinalar a presença de tendências céticas no nominalismo medieval. Estas tendências ou estratégias céticas, que dizem respeito a questionamentos "epistemológicos" na filosofia natural, se intensificam ao final do século XIII e ao longo do século XIV, como se pode notar, p.ex., em pensadores como Duns Scotus, Tomás de Aquino, Guilherme de Ockham (ca.1298-ca.1349) e Jean Buridan (ca. 1300-ca. 1358). Como não se podem 
identificar referências significativas a textos céticos antigos nestes autores, costuma-se explicar que estas tendências céticas surgem neste contexto independentemente do ceticismo. (Marcondes, 1993; Bermudez, 2000; Floridi, 2002).

Embora não haja influência do ceticismo antigo no nominalismo escolástico, por outro lado alguns pensadores medievais citam diretamente o Contra Academicos de Santo Agostinho, como é o caso de João de Salisbury, e Henrique de Gand (ca. 1217 - 1293), que cita o Contra Academicos extensamente nos dois primeiros artigos de sua Summa, bem como os Academica de Cícero (o qual utiliza como uma autoridade, da mesma forma que Agostinho).

Logo, a pergunta que se faz é: em que medida se pode notar a presença do ceticismo no período medieval? Estas "questões céticas" teriam uma raiz no período a partir de uma releitura das fontes céticas clássicas ou independentemente delas? Responder diretamente a estas questões não parece ser possível nos limites deste trabalho, sendo a nossa intenção apenas mostrar a significância que o conceito de dúvida recebe no período da Alta Idade Média. Embora isto possa ter ocorrido de diversas formas, e por diversos caminhos, destacaremos dois modos ou contextos em que a dúvida recebe destaque no período como um conceito filosófico:

1) Na filosofia natural e no nominalismo do século XIV, a problemática suscitada pela retomada do aristotelismo e especulações a respeito da onipotência divina e suas consequências epistemológicas transformam o modo de se avaliar o conhecimento humano, conferindo proeminência aos graus de certeza que o conhecimento humano seria capaz de atingir.

2) $\mathrm{Na}$ teologia moral de Jean Gerson, a casuística é combinada ao probabilismo (doctrina probabilitatis), em que são elaborados os diferentes graus de certeza; e João de Salisbury retoma a concepção de Cícero da integridade intelectual proporcionada pela capacidade de duvidar. Em ambos os casos, podese pensar que o conceito de dúvida é elaborado em conexão com a liberdade. 
Um início possível para se pensar nas "questões céticas" da filosofia natural escolástica é através da influência da retomada de Aristóteles. As traduções de Aristóteles e dos seus comentadores árabes chegam em grande quantidade à Universidade de Paris no início do século XIII, quase concomitantemente à sua fundação (ca. 1210). O aristotelismo rapidamente se estabelece como a força intelectual dominante do pensamento escolástico, presente no currículo tanto das artes liberais quanto das faculdades de teologia e medicina.

Primeiramente, a definição de conhecimento proposta por Aristóteles é submetida a uma comparação com a teologia. De que modo se pode considerar o conhecimento teológico um conhecimento científico? Um dos primeiros a aceitar tal desafio é Alberto Magno (1193-1280), frade dominicano e professor da Universidade de Paris. Em seu comentário aos Analytica Posteriora (Liber I, posteriorum, Tratactus I) escreve:

Um ser humano deve preencher sua alma não com o que é [meramente] plausível (probabile) e opinável (opinabile), pois estas não envolvem uma disposição estável (stantem) na alma, e sim com coisas que são demonstráveis e certas, as quais tornam o intelecto certo e estável, já que tais coisas são elas mesmas certas e eternamente estáveis. E disto fica claro que apenas isto [...] consiste no fim e no mais perfeito, sendo o incondicionalmente desejável dentre as ciências lógicas. (Comentários, I.1.1, ed. Jammy, I: 514 ${ }^{\mathrm{a}}$, apud Pasnau, 2010, p. 365)

Apesar de reafirmar o modelo antigo segundo o qual a estabilidade do conhecimento deriva da estabilidade do objeto de conhecimento, nota-se que a ênfase na certeza diz respeito a uma adaptação a considerações de outra natureza. O estado cognitivo ideal, e o modo como os efeitos gerados pela certeza do conhecimento se relacionam aos efeitos que surtem na alma serão temas recorrentes nas adaptações da episteme aristotélica à scientia medieval. Estas adaptações levam, por um lado, à diferenciação cada vez mais clara entre filosofia e teologia, bem como entre as diferentes fontes de conhecimento, os modos de conhecer e os seus respectivos graus de certeza. Este tema é recorrente no período, podendo-se encontrá-lo em diversos autores. Duns Scotus (1266-1308) escreve: 
A primeira condição, que a scientia seja uma cognição dotada de certeza, excluindo toda decepção, opinião e dúvida, aplica-se a toda virtude intelectual, pois uma virtude intelectual é uma perfeição do intelecto, que o dispõe para uma operação perfeita (Additiones magnae, prol. 1.1 apud Pasnau, 2010, p.360).

A perfeição do intelecto é pensada não só em relação à perfeição do conhecimento apreendido, mas em relação ainda ao estado produzido em quem conhece: o conhecimento perfeito exclui a dúvida, e com ela toda possibilidade de decepção, incerteza e falsas opiniões.

Tomás de Aquino (1225-1274) distingue entre duas formas de conceber a certeza: quanto a sua causa e quanto ao seu objeto. Na medida em que a causa da certeza é a verdade divina, a fé possuiria uma certeza maior do que seriam capazes a sabedoria e o intelecto. Contudo, enquanto a certeza provém do objeto conhecido, e depende da sua adequação à razão, a fé teria um grau de certeza menor do que aquele que a razão seria capaz de atingir. Esta formulação claramente indica, embora ainda não seja assim enunciada, a distinção entre certeza subjetiva e objetiva, a qual desempenhará um papel fundamental na filosofia moderna. $\mathrm{O}$ conhecimento derivado da experiência da fé, que é garantido pela verdade divina, não parece ser passível de nada menos do que uma certeza completa e de uma total infalibilidade.

Deste modo, a leitura de Aristóteles em um contexto em que o pensamento filosófico é determinado pelos paradigmas da teologia cristã parece ter ocasionado uma crescente preocupação com a certeza do conhecimento, o que levaria às crescentes formulações da certeza e da dúvida enquanto conceitos epistemológicos ${ }^{63}$. Gilson (1955) assinala que a "questão epistemológica fundamental" é colocada primeiramente por Henrique de Gand no século XIII.

63 A influência do aristotelismo e discussões sobre o estado cognitivo ideal para o homem seriam, por si sós, capazes de explicar a evidência com que a questão da certeza vem à tona no século XIII? Pasnau considera que a influência exercida pelas traduções árabes seria determinante na escalada da questão da certeza neste contexto - o termo akribeia (precisão) é traduzido como "certeza" na famosa passagem da introdução da Ética a Nicômaco, em que Aristóteles discute os 
O pensamento de Henrique de Gand (ca. 1217 - 1293), professor da Universidade de Paris, que colabora com Etienne Tempier, bispo de Paris, nas Condenações de 1277, é influenciado tanto por Agostinho, quanto por Aristóteles e Averróis. Gand confere uma resposta agostiniana à pergunta pela possibilidade do conhecimento humano com a qual inicia a sua Summa: "Pode o homem saber algo?" Em última analise, Gand reitera a solução de Agostinho no fim de Contra Academicos, a qual é inclusive citada por ele. Gand também discute a posição dos Acadêmicos, bem como a refutação de Aristóteles no Livro IV da Metafísica daqueles que rejeitam o principio de não contradição. Ao longo da sua discussão dos filósofos céticos da antiguidade, desde Demócrito, Protágoras e Leucipo até os Acadêmicos, e inclusive a conclusão negativa do Menon sobre o aprendizado, Gand alarga a compreensão do conhecimento, de modo a incluir o conhecimento sensível. Mantém, no entanto, que o conhecimento que provém dos sentidos não seria capaz, por si só, de resistir aos argumentos céticos, mas sustenta que o conhecimento infalível seria possível através de um elemento não sensível, a saber, a iluminação divina.

De acordo com a doutrina da iluminação da tradição agostiniana, é a intervenção divina que constitui a possibilidade e a garantia do conhecimento humano. Conhecemos porque há uma centelha divina na razão humana, a marca do criador na criatura. É deste modo que o acesso ao real torna-se possível deixada às suas próprias capacidades, a razão humana seria demasiadamente fraca e limitada para produzir um conhecimento seguro. Esta é, inclusive, a base da

possíveis graus de precisão de acordo com a natureza de cada tipo de conhecimento, e afirma ainda que, devido à cultura árabe, esta seria uma tendência inevitável. Deste modo, além das próprias traduções, pode-se pensar na influencia dos comentadores árabes à obra de Aristóteles, como Avicenna e Averróis, e Al-Farabi; este último citado por Pasnau (2010, p. 366): “A certeza significa que estamos convencidos, a respeito daquilo a que conferimos assentimento, de que não poderia ser possivelmente diferente da nossa convicção. Além do mais, estamos convencidos de que tal convicção não poderia ser de outro modo, ao ponto que quando se chega a uma convicção a respeito da sua convicção inicial, mantivemos que aquela, também, não poderia ser de outro modo, e assim indefinidamente". Nesta descrição, a certeza é entendida explicitamente de forma subjetiva, como convicção, deixando uma forte marca no sujeito que a possui. Mas parece derivar, por um processo dialético, da certeza de um princípio, de modo que a certeza completa é confirmada quando se pode derivar indefinidamente de uma premissa infinitas proposições dotadas de tanta certeza quanto as anteriores. 
refutação de Agostinho em Contra Academicos. O conhecimento humano é capaz de obter a verdade devido à mediação divina entre o intelecto humano e o seu objeto. Gand ainda defende e refuta os "Acadêmicos" com o recurso à doutrina da iluminação agostiniana, a qual seria, no entanto, progressivamente abandonada. Ao longo de toda a sua discussão, Gand refere-se constantemente à duvida e à certeza. Gand segue o vocabulário de Cícero e Agostinho, e refere-se à tese de que o conhecimento não é possível em termos de duvidar e colocar em xeque a certeza da qual é passível o conhecimento humano.

Os métodos da filosofia natural escolástica passam a ser aplicados cada vez mais frequentemente à teologia, por exemplo, às Sentenças de Pedro Lombardo (ca.1160), que consistem no texto padrão cujo estudo é obrigatório na faculdade de teologia durante mais de quatro séculos, sobretudo o segundo livro, que trata do Gênesis e da criação. Isto levaria a seguidas sanções da Universidade de Paris, que, em decreto de 1366, manda evitar a infusão de temas da lógica e da filosofia natural aos comentários das Sentenças (Grant, 1996).

O aristotelismo é combatido pelas autoridades eclesiásticas, contudo, sem êxito, devido à atração gerada pela ciência aristotélica, a qual consistia no único sistema então disponível capaz de explicar o mundo somente através de causas naturais. À medida que o aristotelismo, cada vez mais presente no currículo, não pode mais ser combatido através da proibição de obras, a proibição passa a incidir sobre teses ou artigos do aristotelismo, muitas vezes relacionados ao averroísmo, mas também à própria obra de Aristóteles, o que culmina com a condenação, em 1277, de 219 proposições defendidas pelos mestres de artes, dentre as quais diversas diziam respeito diretamente à visão de mundo aristotélica. Esta tentativa é representativa do sucesso inevitável da ciência aristotélica. Presente desde o início do século XIII, o aristotelismo torna-se um dos elementos fundamentais da visão de mundo escolástica. Pode-se afirmar que não é possível entender a Escolástica ou os seus desenvolvimentos posteriores sem referência ao impacto nela causado pelo aristotelismo, tanto nas tentativas de reprimir o aristotelismo, quanto na busca por meios de conciliá-lo com a doutrina cristã (Gilson, 1955). 
As condenações, entretanto, geram o efeito contrário do pretendido, e impulsionam ainda mais os questionamentos da filosofia natural escolástica, bem como são aplicadas a questões propriamente teológicas - o que de qualquer forma talvez já não fosse mais possível evitar. Com as condenações, ganham cada vez mais terreno as especulações sobre a possibilidade hipotética de uma intervenção divina no mundo que confrontaria diretamente com a visão de mundo aristotélica. Por exemplo, na proposição 34 se lê: “Que a causa primeira não poderia criar uma pluralidade de mundos". A impossibilidade de uma pluralidade de mundos é uma tese sustentada por Aristóteles que se coloca em conflito com a potência absoluta de Deus. Sendo o costume sustentar que a onipotência divina deve ser pensada como irrestrita, exceto nos casos em que violaria o princípio de não contradição, de acordo com a condenação deste artigo, os teólogos são, por assim dizer, "forçados" a conjecturar que, caso esta fosse a vontade divina, uma pluralidade de mundos seria possível ou mesmo poderia vir a existir. De modo a não se restringir a onipotência divina, multiplicam-se especulações, secundum imaginationem, a respeito de hipotéticas "impossibilidades naturais" em referência à visão aristotélica do mundo natural.

A partir da noção da potentia Dei absoluta, especula-se que uma hipotética intervenção divina no mundo poderia invalidar todo o conhecimento. Se Deus é onipotente, e, portanto, pode nos iludir, toda a realidade ou um aspecto dela poderia mudar a qualquer instante, bem como o modo como as coisas aparecem para nós poderia ser inteiramente distinto de como realmente são. Deste modo, há a possibilidade de que Deus mantenha um objeto inexistente como existente para nós; de modo que não haveria garantias para o conhecimento humano, podendo ser, em sua totalidade, falso. Deus poderia nos enganar constantemente, de modo a nenhuma das nossas sensações corresponderem à realidade.

Deste modo, a partir do início do século XIII, com a influência exercida pelo renascimento do aristotelismo, o modelo de conhecimento aristotélico é apropriado pelo pensamento cristão e, deste modo, sofre alterações significativas. Uma delas diz respeito à questão da certeza do conhecimento. Pode-se localizar 
nesta época o surgimento da questão da certeza como central para a reflexão sobre o conhecimento humano. O padre francês Jean Buridan (1300-1358) distingue da seguinte forma os diferentes graus de certeza:

No gênero da cognição humana há vários tipos de certeza e evidência. Quanto a nós, a certeza não deveria ser chamada de scientia ou assentimento a menos que seja firme - ou seja, sem temer [que seja o oposto]. Quanto à proposição, um tipo de certeza é aquela que pertence a uma proposição tão firmemente que não há nenhum poder pelo qual ela (ou qualquer outra semelhante a ela) possa ser tornada falsa. . . Outra certeza humana quanto à proposição é obtida quando a proposição é verdadeira e não pode ser tornada falsa por nenhum poder natural ou modo natural de ação, embora possa ser tornada falsa por um poder sobrenatural e de uma maneira miraculosa. (Summulae de dialectica VIII.4.4, tr. Klima, p. 709)

\begin{abstract}
A distinção entre certeza natural e sobrenatural (ou divina) pode ser vista como um modo pelo qual Buridan resguarda o conhecimento contra as dificuldades que haviam sido geradas por Nicolau de Autrecourt (ca. 1300- ca. 1350) a respeito do conhecimento sensível ${ }^{64}$. De modo a garantir a confiabilidade do conhecimento, Autrecourt sustenta que a única forma de conhecimento dotado de certeza é aquele que diz respeito ou a uma experiência sensível imediata, ou que poderia ser demonstrada diretamente a partir do princípio de não contradição. Para além desta fundação única para o conhecimento, todas as outras conclusões seriam menos que certas. Portanto, de modo a garantir a certeza do conhecimento humano, a solução encontrada por Autrecourt consistia em restringir consideravelmente o seu escopo. Em vista disso, Buridan defende a possibilidade de justificação do conhecimento através de vários princípios diferentes, sendo que toda conclusão corretamente derivada de um princípio válido seria dotada de certeza. Não haveria, assim, um único princípio ou um único fundamento legítimo para o conhecimento humano, a partir do qual todo o resto teria necessariamente de derivar. Nota-se que, de qualquer forma, mantém-se a consideração da noção de certeza como uma marca necessária da scientia.
\end{abstract}

64 Cf. Scott (1971). 
A dúvida apresenta-se como conceito filosófico ainda no pensamento de João de Salisbury ( $c a .1115$ - 1180), que notoriamente faz uso de um espectro mais amplo de fontes do que seus contemporâneos, sendo, por isso, considerado por vezes um "renascentista medieval" (ver Schmitt, 1972). O Bispo de Chartres demonstra ter interesse e conhecer a tradição acadêmica, embora não pareça ter tido conhecimento direto dos Academica, mas o seu conhecimento da tradição neoacadêmica estar baseado no Contra Academicos de Agostinho (Schmitt). No Prólogo ao Livro I do Polycraticus certo destaque é conferido à posição acadêmica, e especialmente no Livro VII, em cujo título já afirma serem os acadêmicos mais modestos e, portanto, menos reprováveis do que os filósofos cegos pela temeridade ${ }^{65}$. Deste modo, o "espírito acadêmico" poderia servir como modelo a ser imitado, na medida em que seriam mais modestos se comparados aos filósofos dogmáticos ${ }^{66}$, e de acordo com o qual:

Cada indivíduo deve reter a sua liberdade de julgar para o exame da verdade, e a autoridade dos autores deve ser descontada quando há um ponto de vista mais plausível que a contradiz ${ }^{67}$.

Deste modo, a questão da modéstia e da liberdade do intelecto, enfatizada por Cícero e posteriormente por Omer Talon e Johannes Rosa em seus comentários dos Academica nos séculos XVI e XVII, é destacada já por João de Salisbury. Portanto, a questão da certeza parece surgir com força total no pensamento do século XIV através da confluência de diversos fatores: o pensamento ocidental no contexto do Cristianismo, a retomada da influência do aristotelismo e de seus comentadores árabes no pensamento medieval cristão; e, ainda, as estratégias céticas hauridas do Academica e do Contra Academicos.

65 O Livro VII do Polycraticus tem como título 'Quod Achademici modestiores fuerunt aliis philosophis quos temeritas excecavit ut darentur in sensum reprobum'.

66 Cur autem Achademicos prae ceteris placeat imitari.

67 Salisbury, Policraticus, Prólogo ao Livro VII, alínea 93. 
Jean Gerson (1363-1429), chanceler da Universidade de Paris, concilia o probabilismo à casuística, de modo a chegar a uma solução prática para o problema prático da incerteza moral ${ }^{68}$. Para lidar com esta questão, Jean Gerson precisa alterar o modo tradicional de lidar com a incerteza moral do direito canônico, conhecido como tutiorismo, segundo o qual se deve agir somente de acordo com as melhores razões, e, na ausência, deve-se evitar agir face à possibilidade do pecar.

No contexto de uma crise de autoridade da tradição, provocada, sobretudo, a partir do grande Cisma do ocidente - quando o papa residia em Avignon, o antipapa em Roma, e, ainda, durante certo período um segundo antipapa em Pisa o tutiorismo parece ser uma exigência impossível. Como seria possível, em tal contexto, aplicar a regula magistralis: "Na dúvida, escolha o lado mais seguro" (in dubiis tutior pars est eligenda)? Pois, se há dúvida, como poderia haver lado mais seguro, e como seria possível evitar o perigo moral? Nota-se que a segurança ou a "melhor parte" referida pela regula magistralis diz respeito propriamente à autoridade. Ou seja, na dúvida, fique do lado seguro da autoridade da tradição, ou do grupo cuja autoridade possui o maior peso. No entanto, é justamente uma crise de autoridade da tradição que está em jogo com o Grande Cisma do Ocidente.

A necessidade de agir conforme as melhores razões, em uma época em que não se sabia ao certo à qual autoridade seguir, ou quais razões se deveria aceitar resulta em um constante estado de incerteza e ansiedade. Deste modo, como lidar com a questão da incerteza moral em uma época de crise de autoridade religiosa é o problema com o qual Gerson lida diretamente. Gerson formula o problema da seguinte maneira em De schismate (1403): Desobedecer a um papa legítimo pode levar ao inferno, assim como obediência a um papa ilegítimo ${ }^{69}$.

68 Sigo aqui a exposição de Schussler (2009).

69 "Quia non debent fideles se exponere discrimini; amans enim periculum peribit in illo, inquit Sapiens. Sed obedire homini schismatico vel haeretico ut vero papae, esset discrimen peccati moralis ut videtur; et non obedire eidem, si sit verus papa et non schismaticus, est similiter discrimen." Jean Gerson, 'De schismate', in P. Glorieux (ed.), Oeuvres complètes, 10 vols. (Paris: Desclee, 1960-1973), Vol. 6, 43. Citado em Schussler (2009), p. 449. 
Deste modo, em uma época em que as próprias autoridades se dividem a respeito de qual seria a melhor conduta a ser seguida, Gerson sustenta que não é preciso nem buscar as melhores razões, nem garantir o apoio da autoridade de um grupo majoritário para justificar a conduta moral e evitar o pecado mortal. Basta poder justificar a conduta através de uma boa razão, não necessariamente a melhor razão, baseada na autoridade de algum grupo reconhecido, e não necessariamente o grupo majoritário.

Gerson denomina a certeza necessária para a ação de "certeza moral" (certitudo moralis), termo aparentemente cunhado por ele. Gerson entende a certeza moral como sendo consideravelmente inferior se comparada ao nível de certeza capaz de ser atingido em outros domínios práticos, como, por exemplo, a certeza possível para especialistas em ética e na política. No entanto, com este novo conceito, Gerson concede maior grau de liberdade para tomadas de decisão e para agir.

Em De consolatione (1418), após chamar a atenção para o fato de Aristóteles já haver exposto a noção de uma certeza moral para a conduta na Ética a Nicômaco, Gerson afirma que, embora os acadêmicos negassem a certeza do conhecimento natural, não poderiam negar a certeza moral, que deriva de raciocínios prováveis e conjecturas imprecisas:

Se os Acadêmicos negassem inteiramente tal certeza, e se também dissessem não ser ela suficiente para agir moralmente, de que modo poderiam presumir ou cometer qualquer bem ou omitirem-se de qualquer mal, em conformidade com um juízo racional, que deve ser certo, tal como a virtude para eles é dotada de certeza, ou não é virtude ${ }^{70}$ ?

Embora não houvesse tal conceito na Antiguidade, a intenção de Gerson é mostrar que inclusive os academicos aceitariam esta noção, pois, caso contrário,

70 "Talem certitudinem si penitus negaverint Academici, si non eam praeterea sufficientem dixerint ad aliquid moraliter operari, viderint qua ratione praesumpserint aliquid vel agere bunom, vel omittere malum, conformiter ad judicium rationis, quale debet esse certum, sicut certa est in se virtus, alioquin virtus non est" (Jean Gerson, De Consolatione, 231, apud Schussler, 2009, p. 458n32). 
tornariam impossível a ação moral e a virtude, de modo nenhum negada por eles. Em sua referência aos “academicos”, Gerson menciona especialmente Sócrates, Arcesilau e Cícero, de modo que a sua discussão a respeito da aceitação dos acadêmicos da certeza moral, e sua negação da certeza natural teria em vista uma única Academia.

Na concepção de Gerson de "certeza moral”, o probabilismo traduz-se pela possibilidade de se justificar a conduta prático-moral através não somente das melhores razões (tutiorismo), mas por razões que, mesmo assumidamente inferiores ou de menor peso, no entanto, podem, ainda, ser justificadas e legitimadas através de alguma autoridade reconhecida. Pode-se pensar que, com isso, a dúvida deixa de assinalar somente a possibilidade de se cometer uma falta moral, agir indevidamente ou cometer um pecado, e passa a apontar para a possibilidade de se abrir outros caminhos para condutas práticas que podem ser igualmente justificáveis, alargando a esfera da ação prática e da decisão moral, de modo que se atrela à liberdade de ação, processo pelo qual a noção de dúvida é valorizada. Pode-se pensar que, desta forma, Gerson reabilita um sentido da noção de dúvida em que esta não se opõe, necessariamente, à liberdade. De acordo com o conceito de certeza moral, para agir e evitar o pecado não é necessário excluir toda a possibilidade de dúvida.

De acordo com Schussler, o pensamento de Gerson indica como o interesse pela tradição cética não ocorre apenas com a Reforma Portestante, podendo ser localizado ao menos desde o início do século XV. Neste sentido, Schussler afirma (2009, p. 457):

Se um choque epistemológico fosse necessário para criar um interesse no ceticismo, o Grande Cisma do Ocidente teria sido suficiente para promovê-lo no início do século XV, apenas algumas décadas antes da retomada do ceticismo antigo de fato começar.

Schussler assinala como a ruptura com a tradição e a crise da sua autoridade, ocasionando o problema de ausência de critério, ocorre já no contexto do Grande Cisma do Ocidente, problemas com os quais lida Jean Gerson. No entanto - assim 
como ocorre na Reforma - pode-se ver que o interesse de Gerson ao discutir a tradição acadêmica diz respeito mais diretamente às noções de dúvida e certeza e ao probabilismo do que a questões da filosofia cética antiga. O pensamento de Gerson pode ser visto, no que diz respeito ao seu interesse pela tradição acadêmica, em sintonia com o interesse característico do período moderno de interpretar o ceticismo através da dúvida e da certeza, desenvolvendo estas noções e uma nova compreensão do ceticismo em uma relação de reciprocidade.

Entre os séculos XII e XIV, as noções de dúvida e certeza tornam-se conceitos centrais no pensamento ocidental, especialmente em reflexões sobre a natureza do conhecimento e a conduta moral e religiosa no contexto do pensamento cristão. E pode-se afirmar que, a partir do século XIV, o probabilismo defendido por Cícero exerce uma influência significativa, misturando-se ao questionamento da certeza em voga no período. Ainda que não houvesse o conhecimento direto do Academica, o probabilismo de Cícero era facilmente acessível através das diversas obras em que expõe esta posição, obras como o $D e$ oficiis, que nunca foram perdidas. Além disso, pode-se afirmar que o seu probabilismo exerce uma influência considerável, especialmente tendo-se em vista que Cícero pertencia ao currículo de estudos regulares das artes liberais. Deste modo, independentemente da discussão cética do Academica, seria possível se deparar com o probabilismo através do estudo da retórica, oratória, da filosofia moral e política. No entanto, há outra via pela qual a dúvida é introduzida como conceito relevante para o pensamento filosófico, que diz respeito ao contexto próprio da escolástica medieval, dominado pelo pensamento cristão e influenciado pelo surgimento do aristotelismo. Estas duas tradições, que são independentes entre si, em muitos casos se misturam e se sobrepõem, de modo que ambas propiciam a maior relevância concedida às noções de dúvida e certeza pelo pensamento filosófico.

Nota-se que os desdobramentos da noção de dúvida durante a escolástica medieval se dão em dois sentidos opostos: por um lado, no domínio da teologia moral cristã, especialmente a partir do probabilismo moral de Jean Gerson, e também em João de Salisbury em referência a Cícero, a dúvida recebe uma 
conotação positiva, vindo a representar uma maior liberdade de escolha, tanto para a decisão moral, quanto para o campo da ação em geral. Com o conceito de certeza moral de Jean Gerson, a dúvida deixa de ser vista como oposta à certeza e à liberdade de escolha e de ação. Tomando-se a dúvida como uma possibilidade legítima, a própria noção é revitalizada, recebendo um sentido positivo atrelado à liberdade. E pode-se verificar dentre os humanistas que a dúvida, a hesitação e o “adiamento da decisão" não são apenas marcas de incerteza, seja moral ou epistemológica, e, portanto, recrimináveis, mas passam a assinalar a capacidade de livre deliberação e escolha. Nota-se que a teologia moral católica será influente no Renascimento, em especial para a Companhia de Jesus no século XVII, bem como irá influenciar, por exemplo, Lutero, que cita Gerson com admiração.

Por outro lado, o uso epistemológico da noção de dúvida recebe proeminência no contexto da filosofia natural escolástica. Neste domínio, o que se pode denominar de eixo dúvida e certeza é elaborado em um padrão de medida e de avaliação do grau de confiabilidade do conhecimento humano, de modo que é ressaltada a conotação pejorativa da dúvida, na condição de uma marca da incerteza e índice de desconfiança a respeito do conhecimento natural.

Veremos a seguir como esta ambiguidade da dúvida - em sentido negativo, como o oposto da certeza; e positivo, como indicativa de liberdade - amplamente elaborada em relação a questões centrais para o pensamento do século XIV, penetra no contexto do Renascimento como um dos elementos atuantes do "quadro conceitual" do pensamento dos humanistas italianos. O eixo dúvida e certeza, que havia se tornado uma "ferramenta conceitual" fundamental, sobretudo nos séculos XIII e XIV na França, faz-se presente também entre os humanistas italianos, previamente à retomada do ceticismo, e se insere na compreensão do ceticismo desde o início da sua redescoberta pelos humanistas florentinos. Pode-se pensar que o pensamento escolástico confere como herança ao início do período moderno a valorização conceitual das noções de dúvida e certeza como uma das suas conquistas intelectuais. 
De todo modo, a noção de dúvida torna-se proeminente no contexto da Escolástica tanto em conexão quanto independentemente a referências à tradição cética antiga. Deste modo, pode-se pensar que a dúvida tenha sido apropriada pela filosofia por diversos caminhos, inclusive em conexão com "questionamentos céticos" hauridos das fontes antigas. Nota-se que, no mais das vezes, as questões próprias ao contexto da Escolástica que são identificadas como questões céticas dizem respeito a questionamentos relativos às noções de dúvida e certeza. Deste modo, é possível que as contribuições filosóficas do pensamento escolástico medieval tenham influenciado o modo de pensar do início da modernidade, e, neste sentido, as questões da dúvida e certeza tenham sido sobrepostas ao entendimento do ceticismo na ocasião da sua redescoberta.

\section{3}

\section{Os humanistas italianos}

Como vimos, Cícero coloca a dúvida em uma posição de destaque em sua concepção de filosofia e de sabedoria, e a centralidade do conceito de dúvida no seu pensamento filosófico não passa despercebida aos humanistas. No Livro IV dos Rerum memorandarum libri, escritos entre 1343 e 1345, Petrarca escreve:

[...] em seus livros do Academica... Cícero [expõe] que nada deve ser firmemente mantido, mas tudo colocava em dúvida. ${ }^{71}$

E, um século após Petrarca, Bartolomeo Scala (1430-97), em De Nobilioribus Philosophorum Sectis (8, 6-15, apud Hunt, 1998, p. 38), cita a passagem dos Academica (Acad. I, 17) em que a maiêutica socrática é pensada através do conceito de dúvida: "Illam enim socraticam dubitationem de omnibus

71Marcus Tullius ... in ipsis Achademicorum libris, in quibus nichil omnino firmandum sed de omnibus dubitandum disputat ..." [Patrarca, apud Schmitt, p. 45] 
rebus et nulla affirmatione adhibitia consuetudinem disserendi...", comentando, em seguida, que Cícero buscava espelhar-se em Platão e na exposição da prática socrática dos seus diálogos.

No entanto, as referências a Cícero não são a única fonte para a elaboração filosófica do conceitos de dúvida entre os humanistas, tanto quanto os usos filosóficos do conceito de dúvida não indicam um modo único de se concebê-lo. Vimos que na obra de Cícero já se pode notar a ambiguidade na concepção da dúvida: no que diz respeito ao seu probabilismo acadêmico ou eclético, a dúvida é índice de liberdade e integridade intelectual, mas, para a ação moral, a dúvida marca a possibilidade do erro. E, como vimos no capítulo anterior, as noções de dúvida e de certeza tornam-se proeminentes durante os séculos XIII e XIV; fenômeno que ocorre tanto independentemente de fontes céticas, quanto em conexão com a influência da filosofia neoacadêmica e do probabilismo de Cícero, como se pode ver em João de Salisbury e Jean Gerson.

Deste modo, tendo-se como referência Cícero ou derivada de outras fontes, ou por outros caminhos, não necessariamente depreende-se uma compreensão única da dúvida, do seu significado ou do seu valor, mas, pelo contrário, nota-se uma mesma ambiguidade em que a noção de dúvida se envolve. Lorenzo Valla, contemporâneo de Jean Gerson, e posteriormente Omer Talon frisam a positividade da dúvida, ao passo que Coluccio Salutati, amigo de Petrarca, e Gianfranceso Pico della Mirandola, contemporâneo de Omer Talon, parecem enxergar na dúvida apenas um sentido negativo, como o sinônimo de incerteza.

Pode-se encontrar a valorização da noção de dúvida no pensamento de Lorenzo Valla (1407-1457), que escreve em De Voluptate (1431):

[...] se há tanta incerteza nos julgamentos das ações dos homens, é injusto interpretar da pior maneira as ações duvidosas e chamar alguém de avarento em vez de parco, curioso em vez de diligente, ridículo em vez de civilizado e teimoso em vez de firme. Mas, se alguma vez o devemos fazer, então eu prefiro que se faça em nossa consideração; não porque gostaria que fôssemos injustos contra $\mathrm{n}[\mathrm{os}$ mesmos, mas para evitar que nos enganemos pelo nosso amor próprio. Para evitar que alguma inveja ou ódio encoberto distorçam a nossa percepção de justiça e 
verdade quando julgamos alguém, nosso juízo deve sempre tender para a interpretação mais benevolente. Como o faziam aqueles sapientíssimos atenienses, os quais, em caso de paridade de votos, absolviam o acusado fazendo prevalecer a alternativa mais branda - como aqueles casos envolvendo a pena de morte que apresentassem votos pares para condenação e perdão. Quando nós não podemos interpretar as ações dos homens de nenhum outro modo senão no pior senso, não é impróprio recomendar um atraso na decisão, uma vez que podemos muito facilmente nos enganar - como habitualmente se diz daqueles que são invejosos ${ }^{72}$.

No modo de pesar razões e argumentos contrários ao se interpretar as ações dos homens, situação em que o julgamento está muitas vezes envolto em incertezas, "não é impróprio recomendar um atraso na decisão, uma vez que podemos muito facilmente nos enganar". Com isso, Valla defende a liberdade de decisão, à qual se inclui como possibilidade legítima o atraso na decisão ${ }^{73}$. $\mathrm{O}$ modo específico que encontra para a defesa da liberdade é salientar a positividade que pode haver em juízos incertos e em ações duvidosas. Considerando possível encontrar algo de valor no que está encoberto pela dúvida e incerteza, Valla legitima o atraso da decisão, de modo a evitar a precipitação e a arrogância, a favor de uma "interpretação mais benevolente" da conduta humana. Em Salutati, por outro lado, não obstante a sua admiração por Cícero, a dúvida é pensada em termos negativos.

Coluccio Salutati (1331-1406), em carta a Lombardo della Seta de 1379, mostra-se interessado em adquirir os "quatro livros do Academica" ${ }^{74}$, e em correspondência do período de 1401-1402 escreve sobre a filosofia acadêmica, época em que parece ter conhecimento direto da obra (Hunt, 1998, p.32). E, com efeito, Salutati viria a adquirir uma cópia do Lucullus (ver Schmitt, 1972, p. 49). Em seu De nobilitate legum et medicinae, de 1398, Salutati reflete sobre a nobreza da medicina a partir da noção de certeza. Schmitt (1972) descreve o modo pelo qual Salutati aborda a questão:

72 Valla, 1. De Voluptate in: BATISTA, A. L. 2010, p. 218.

73 Nota-se que, a partir da retomada do ceticismo, a própria noção de epoche será interpretada como uma dúvida do adiamento.

74 Apenas dois livros dos Academica sobreviveram, dos quatro livros que Cícero escrevera, como se pode aprender a partir da sua correspondência. Ver Ibidem. 
Ao comparar as profissões do direito e da medicina, Salutati levanta a questão acerca de qual das duas seria dotada de maior certeza. Neste tratado ele opta pelo direito, considerando-o ser mais nobre do que a medicina. Os seus argumentos são amplamente retiradas de fontes mais tradicionais e mais bem conhecidas do que os Academica, embora em um lugar refira-se à posição acadêmica de que todo argumento racional pode, de alguma forma, ser colocado em dúvida.

A consideração da nobreza, tema comum dentre os humanistas florentinos, é pensada por Salutati através da noção de certeza. A noção de certeza é utilizada como o indicador da nobreza superior que o direito possuiria em comparação com a medicina. Na mesma obra, Salutati refere-se aos acadêmicos com o seguinte comentário:

Pode-se tornar duvidosa toda verdade que é percebida pela razão por uma razão contrária, fato ao qual os acadêmicos eram incrivelmente dedicados, [no entanto] a moral média em todos os casos é bastante certa ${ }^{75}$.

Salutati frisa a necessidade de se possuir a certeza, tanto para a moralidade, quanto para o conhecimento, de modo que a conotação positiva da dúvida não parece ser valorizada. A dúvida não indica uma capacidade, mas é apenas índice de uma falta.

Assim, nota-se que as noções de dúvida e certeza já estão presentes de forma significativa no modo de pensar dos humanistas, tanto em conexão direta com uma avaliação filosófica do conhecimento, quanto em questões práticas, relativas à ação, liberdade, e conduta moral, em que o probabilismo ciceroniano e o ideal de integridade acadêmica exercem uma influência significativa. Em ambos os aspectos, há precedentes medievais para o tratamento destas questões em que se faz referência direta a Cícero, e aos Academica, articulando-se o probabilismo às questões da época.

75 ...quoniam omne verum quod ratione percepitur dubitabile fieri possit contraria ratione, cuius rei fuerunt Academici mirabiliter studiosi, morale médium est in omnibus valde certum. 
Além da conexão entre o probabilismo ciceroniano e o ideal humanista de liberdade, nota-se que as noções de dúvida e certeza já pertencem em geral ao quadro conceitual do pensamento humanista; consistem em "ferramentas conceituais" presentes em sua visão de mundo e em seu modo de pensar. Neste sentido, não há uma quebra ou oposição entre o pensamento escolástico medieval e o pensamento humanista. Além da influência de Cícero, a questão da certeza do conhecimento humano, que se torna proeminente no contexto da escolástica, é um dos caminhos pelos quais a dúvida é apropriada como conceito relevante para o pensamento filosófico.

Amplamente vigentes em Paris a partir do século XIII, as noções de dúvida e de certeza se fazem igualmente presentes no horizonte intelectual dos humanistas italianos. Durante o período escolástico, com a teologia moral cristã, em conexão com o probabilismo, a noção de dúvida recebe uma conotação positiva, e chega ao Renascimento como representativa de um ideal de liberdade de ação e pensamento. Ainda, com a filosofia natural, as noções de dúvida e certeza tornam-se centrais para a avaliação do conhecimento, avançando em direção a um novo modo de pensar e um novo modelo de conhecimento. Deste modo, a dúvida não é introduzida ao ceticismo na modernidade tão somente devido à influência de Cícero ou de seu vocabulário. A noção de dúvida já havia se tornado um fenômeno cultural, que é amplamente difundido entre os humanistas renascentistas, e desempenha um papel central nas controvérsias da Reforma.

Portanto, a noção de dúvida é amplamente utilizada como conceito filosófico entre os humanistas no século XV, e inclusive antes da redescoberta das fontes céticas na década de 1430 (os manuscritos de Sexto Empírico e a tradução de Traversari da Vida de Pirro). Deste modo, a introdução da dúvida no ceticismo não deve ser pensada como um momento pontual que se possa localizar em uma escola ou autor específico, como tampouco se deve apenas às traduções das fontes céticas antigas, mas está conectada a um fenômeno cultural mais amplo, sendo mais propriamente o produto de uma época. O contexto cultural, econômico e 
político da Alta Idade Média e do início do período moderno podem ser mencionados como fatores determinantes deste fenômeno cultural: a emergência das cidades-estado italianas, o grande Cisma do Ocidente, a crise da escolástica, a descoberta do Novo Mundo, a Reforma Protestante e o próprio humanismo e sua redescoberta do passado clássico; todos estes acontecimentos históricos têm consequências profundas e levam a novos desenvolvimentos intelectuais - sendo um deles a valorização da dúvida como conceito filosoficamente importante.

A mesma oposição na consideração do valor da dúvida que se pode notar no pensamento de Salutati e Valla encontra-se posteriormente no pensamento de Gianfrancesco Pico della Mirandola em comparação a Omer Talon. Há uma forte presença do eixo dúvida e certeza no pensamento de Gianfrancesco Pico della Mirandola (1469-1533), que é um dos poucos a conhecer e fazer uso da obra de Sexto Empírico no início do século XVI. Gianfrancesco Pico publica em 1520 a obra Examen Vanitatis (1520), dividido em seis livros. Os três primeiros livros são dirigidos contra a filosofia pagã em geral, em vistas de mostrar (na contramão da atitude intelectual de seu famoso tio, de buscar uma pax philosophica) como toda a história da filosofia pagã é marcada por uma dissensão generalizada. Os três últimos livros consistem em ataques diretos ao corpus aristotélico, com o objetivo de demonstrar que não há nenhuma "ciência aristotélica" e, ainda, que nenhuma ciência em sentido aristotélico seria possível.

Para Gianfrancesco Pico há uma única verdade, que é a verdade cristã. De acordo com Gianfrancesco Pico, a "vaidade pagã consiste na aceitação da superstição no lugar da religião, da incerteza no lugar da certeza, da falsidade no lugar da verdade". Pico sustenta como critério de verdade a certeza absoluta, e, assim, considera que somente o conhecimento concedido diretamente por Deus poderia ser estabelecido adequadamente ou de forma aceitável. Portanto, Pico julga que um conhecimento apenas provável não seria conhecimento nenhum, e considera vão que se procure em Aristóteles por qualquer certeza, tanto quanto em toda e qualquer filosofia pagã. 
Nota-se que a noção de certeza no pensamento de Gianfrancesco Pico ocupa um lugar de destaque. O seu critério de verdade é nada menos que uma certeza absoluta, e sustenta que somente a verdade das Escrituras, revelada diretamente por Deus, seria capaz de satisfazer a tal critério. Deste modo, apenas a revelação divina é capaz de fornecer a verdade; a racionalidade humana e seus argumentos são todos eles suscetíveis a disputas e erros infindáveis, bem como toda religião, que não seja cristã, e toda a filosofia pagã consistiriam em uma "perversão da verdade”. Estas religiões, segundo Pico, e em consonância com a opinião de Savonarola, Ficino, e Tomás de Aquino, seriam "imperfeitas, incertas, e cheias de erros." (cf. Schmitt, 1967, p. 37).

Portanto, pode-se afirmar que Pico equaciona, como equivalentes entre si, por um lado, a perfeição, a verdade absoluta e a certeza; e, por outro lado, o provável, o incerto, e o falso. Nota-se, portanto, que Pico faz uso do que chamamos de eixo dúvida e certeza como critério de verdade - embora a sua natureza possa ser a de um pressuposto geral e até mesmo irrefletido do seu pensamento, através do qual reconhece apenas as Escrituras como a única fonte existente da verdade, pois seria dotada de uma "certeza absoluta"; e descarta especialmente a filosofia aristotélica, e a filosofia pagã em geral, bem como todas as religiões não cristãs como falsas, pois seriam apenas "prováveis" e "incertas".

Omer Talon (c. 1510-1562) publica em Paris sua obra Academia (1547), um comentário introdutório que acompanha a tradução do Academica Posteriora. Para Schmitt (1972, p. 82), este parece ser o "primeiro estudo sério" sobre os Academica a ser publicado, bem como fornece "o único testemunho escrito de que haveria um grupo de nouveaux académiciens em Paris em meados do século XVI". Um dos principais interesses de Talon em seu trabalho sobre os Academica diz respeito à liberdade de filosofar.

É a liberdade própria dos Acadêmicos, i.e., de verdadeiros homens (pois considero que um significa o mesmo que o outro), que necessariamente na filosofia não se submetem às leis e regulações de nenhum homem. É também a sua modéstia, pois introduzem nenhum julgamento próprio a respeito de coisas incertas, bem como a 
sua prudência, pois ao não asseverar a sua própria autoridade comparam as causas das coisas e trazem à tona o que possa ser dito contra qualquer opinião; também a sua sabedoria, pois se devotam à única verdade de toda a vida, como se fosse uma deusa, e valorizam isto mais do que o testemunho de todos os filósofos ${ }^{76}$.

A valorização humanista da liberdade se manifesta de modo radical em Omer Talon, ao ponto de considerar "verdadeiros homens" apenas os que possuem a liberdade. A dúvida é ao mesmo tempo sinal de prudência e modéstia; justificando-se como um atraso na decisão ao não julgar "a respeito de coisas incertas". Esta liberdade acadêmica, tal como é transmitida por Cícero, faz com que os academicos se distiguam dos outros filósofos, aos olhos de Talon, "tanto quanto escravos de homens livres" 77 . Deste modo, Talon é um defensor fervoroso da integridade intelectual acadêmica, que viria em seguida se tornar o ideal de libertas philosophandi. De acordo com Sutton (1953), a expressão 'libertas philosophandi' encontra-se primeiramente no título completo do Tratado políticofilosófico (1670), porém, é expressa em seus termos radicais já na Apologia pro Galileo (1622), de Tommaso Campanella - o que, como se pode ver, ocorre igualmente no Academia, de Omer Talon. Portanto, pode-se pensar que a apropriação da dúvida pelo pensamento filosófico no início do pensamento moderno seja um fenômeno cultural amplo, e não possua uma única raiz, mas se manifeste em diversos autores de modos diferentes.

De todo modo, é visível que as noções de dúvida e certeza figuram como conceitos relevantes no modo de pensar tanto dos filósofos escolásticos quanto dos humanistas italianos; podendo-se considerar que já pertençam ao "quadro conceitual" básico de seu pensamento.

São notáveis os modos contrários de se pensar a dúvida, que se mantêm aproximadamente iguais desde a escolástica aos humanistas. Por um lado, a dúvida enfatizada por Buridan, Salutati, Gianfrancesco Pico opõe-se ao

76 TALAEUS, AUDOMARUS (Orner Talon). 1547. Academia. Eiusdem in Academicam Ciceronis fragmentum explicatio. Lutetiae: M. David, I, 20. Apud Schmitt, 1972, p. 84

77 Talon, 1547, apud Schmitt, 1972, p. 88. 
dogmatismo como índice de incerteza no conhecimento, sendo um obstáculo para a sua obtenção. Por outro lado, a noção de dúvida elaborada em João de Salisbury, Lorenzo Valla, Omer Talon opõe-se ao dogmatismo enquanto representativa de uma "atitude crítica", uma capacidade do pensamento que está livre para filosofar e buscar a verdade sem os impedimentos gerados pela adesão a uma doutrina dogmática. Logo, por um lado, com uma conotação negativa, o que se poderia chamar de "dúvida comum" opõe-se à certeza, à verdade e à obtenção do conhecimento dogmático. Por outro lado, com uma conotação positiva, a "dúvida filosófica" opõe-se à presunção e à temeridade do dogmatismo, representando a abertura de busca da verdade.

É interessante notar que esta ambiguidade se encontra no pensamento dos humanistas ocorre previamente à retomada do ceticismo, e já se encontra inclusive no pensamento escolástico. Em ambos os casos, ocorre independentemente de fontes céticas antigas. A ambiguidade da dúvida não diz respeito ao ceticismo propriamente, mas está relacionada aos modos de apropriar-se filosoficamente e de se fazer uso da dúvida. Ao se atribuir à dúvida o significado de oposição ao dogmatismo, como o faz Cícero quando considera a capacidade de duvidar como a marca distintiva entre dogmáticos e acadêmicos, Lorenzo Valla, com o "atraso da decisão", e Omer Talon, em sua identificação com a liberdade e a modéstia, cria-se um novo sentido filosófico para a noção de dúvida, que dificilmente se harmoniza com o seu entendimento comum.

Nota-se, em primeiro lugar, que o significado da noção comum de dúvida não assinala uma capacidade, mas um estado: "estamos em dúvida, por isso, ainda não fomos lá". A "capacidade de duvidar" não parece ser um sentido "natural" ou primário da noção de dúvida: quando se analisa o conceito de dúvida, não se segue espontaneamente a ideia de um antidogmatismo, mas a ideia de vacilação, de uma vacilação do "dogma”. Em segundo lugar, pode-se notar que o sentido comum da dúvida como um estado de vacilação parece ser contrário ao sentido intelectual ou filosófico atribuído à dúvida enquanto "capacidade". Como assinala uma vacilação, hesitação, ou indecisão do espírito, a noção comum de 
dúvida costuma ter um sentido pejorativo, indicando a presença de algum obstáculo ou dificuldade parauma tomada de decisão.

Ao se interpretar o ceticismo através da dúvida, esta ambiguidade passa a acompanhá-lo decisivamente, o que se pode verificar através dos diversos sentidos atribuídos ao ceticismo na modernidade até os dias atuais. Uma vez que é redescoberto e reinterpretado através da noção de dúvida, a ambiguidade presente nesta espraia-se para o entendimento do ceticismo, tornando-se ele próprio ambíguo, no que diz respeito tanto ao seu significado quanto ao seu valor filosófico. Deste modo, é interessante notar como a ambiguidade da dúvida é corresponde aos "dois ceticismos" assinalados por Olaso como os modos característicos de se conceber o ceticismo na modernidade. (1975, p. 28):

Alguns entendem que o cético é um homem que professa uma constante dúvida a respeito de tudo; outros, que é um homem capaz de colocar em dúvida as suas próprias opiniões.

O "primeiro ceticismo" possui uma conotação pejorativa, sendo o cético quem "duvida de tudo": duvida das crenças religiosas, dos costumes, da moral, e especialmente da certeza do conhecimento. Já o "segundo ceticismo" possui uma conotação positiva, cuja influência claramente é acadêmica. De acordo com esta releitura, o pensador cético é ou busca ser um pensador livre de dogmas, que é capaz de duvidar de si mesmo, e questionar o seu próprio ponto de vista e suas crenças: o seu pensamento estaria desimpedido para aproximar-se da verdade de todos os modos possíveis e persegui-la onde quer que possa se manifestar.

Por um lado, ao ser entendido como uma atividade dubitativa, o ceticismo no início do período moderno não possuía necessaria ou exclusivamente uma conotação pejorativa, pois a própria dúvida também era pensada em conexão com a liberdade. Por outro lado, ao ser entendido como uma doutrina que questiona a possibilidade de obtenção da certeza, é possível entender o ceticismo como uma “doutrina" que veicula um modo de pensar frívolo e inconsequente. Como se 
sabe, é esta conotação pejorativa do ceticismo que se torna predominante, como se pode encontrar no julgamento de Descartes no Discurso do Método: os céticos são aqueles que "duvidam por duvidar".

Portanto, pode-se pensar que a ambiguidade dos "dois ceticismos" aponta, na verdade, para uma ambiguidade anterior à retomada do ceticismo, que pertence mais especificamente ao próprio conceito da dúvida do que à filsoofia cética propriamente dita. Cabe lembrar que a ambiguidade dos dois ceticismos pode ser identificada claramente no tratamento e nas elaborações filosóficas do próprio conceito de dúvida, inclusive previamente a este conceito ser introduzido no ceticismo a partir da sua redescoberta no período moderno, como vimos em Cícero, no pensamento escolástico e nos humanistas italianos. Embora o ceticismo seja retomado no Renascimento já entrelaçado à noção de dúvida - como veremos a seguir - pode-se pensar que a presença da dúvida no início do pensamento moderno ocorra independentemente da retomada do ceticismo, sendo resultante de um longo processo histórico que culmina na época moderna. Da mesma maneira, a introdução da noção de dúvida no ceticismo no Renascimento pode ser considerado um fenômeno próprio à época moderna - e externo à filosofia cética antiga e às suas fontes textuais.

Nota-se que em nenhuma das diversas apropriações e usos filosóficos da noção de dúvida que observamos se possa identificar o papel novo e radical que a dúvida viria a desempenhana filosofia moderna. Há em Cícero, em diversos pensadores escolásticos e humanistas italianos uma clara apropriação filosófica do conceito, mas não ainda o seu uso radical como a origem da filosofia. Esta pode ser considerada uma característica do pensamento moderno, que substitui o thaumazein pelo conceito de dúvida como a origem do filosofar (ver Cap. 3). No entanto, antes de Descartes, como veremos a seguir isto ocorre na releitura renascentista do ceticismo, tanto já em suas traduções, como na influente releitura de Montaigne. 


\section{6}

\section{A introdução da dúvida no ceticismo}

Neste capítulo, desejamos pensar como a dúvida foi introduzida no ceticismo a partir da sua retomada na modernidade. Como vimos, Cícero insere a noção de dúvida em sua própria concepção da filosofia neoacadêmica, da qual se considera partidário. No entanto, além dos termos "cético" e "ceticismo" não figurarem em sua obra, os Academica não são bem conhecidos durante o período medieval; há poucas referências e quase nenhuma discussão mais aprofundada sobre a tradição acadêmica, ao menos até João de Salisbury. O mesmo ocorre com as principais fontes da filosofia pirrônica: o capítulo de Diógenes Laércio sobre a vida de Pirro (IX, 11) e a obra de Sexto Empírico é desconhecida durante todo o período medieval (com raras exceções).

A introdução da dúvida no ceticismo ocorre desde a tradução de Ambrogio Traversari do artigo sobre a vida de Pirro de Diógenes Laércio (Vita Pyrrhonis, 1432). Como é com esta tradução que primeiramente surge o vocábulo latino scepticus, pode-se considerá-la o marco tanto da retomada do ceticismo ao Ocidente latino, quanto da introdução da noção de dúvida para se interpretá-lo e compreendê-lo. Portanto, é possível localizar as origens do processo de apropriação das ideias céticas antigas e sua transformação através da noção de dúvida desde o início da retomada do ceticismo no Renascimento. A introdução da dúvida no ceticismo e a sua retomada no período moderno ocorrem concomitantemente: o ceticismo é pensado através da dúvida desde a sua recepção inicial no início do século XV. 


\section{1}

\section{As traduções latinas das fontes céticas}

A introdução da dúvida nas traduções latinas do pirronismo encontra-se registrada desde a tradução de Ambrogio Traversari da "Vida de Pirro" (Vita Pyrrhonis, 1432), que é a primeira tradução latina das Vidas dos filósofos Ilustres de Diógenes Laércio do período moderno. Na passagem em que Diógenes Laércio apresenta as denominações do ceticismo, Traversari insere o termo "dúvida" para explicitar a denominação aporética da escola cética. Após mencionar os discípulos de Pirro - Hecateu de Abdera, Tímon e Nausífanes de Theos -, Diógenes Laércio afirma (Vidas, Livro IX, cap. 11, 69-70), segundo a tradução de

Traversari:

Todos estes eram chamados pirrônicos devido ao seu mestre, mas também aporéticos e céticos devido a sua doutrina, e ainda eféticos e zetéticos. A sua filosofia é denominada zetética porque está sempre ocupada com a investigação da verdade. Chama-se cética por sempre buscar, mas nunca encontrar. Também é chamada efética por conta do seu resultado, devido à ambiguidade que permanece após a investigação, e aporética porque seus discípulos estão sempre em dúvida. E pirrônicos, como dissemos, devido a Pirro. ${ }^{78}$

Aprende-se com a leitura da Vita Pyrrhonis, de Traversari, que a escola cética designa-se "aporética" porque os seus seguidores "estão sempre em dúvida" (Aporetica uero quod eius sectatores semper addubitent). No entanto, o texto de Diógenes Laércio simplismente afirma: os céticos são denominados aporéticos por estarem frequentemente em aporia (aporein). Diógenes utiliza o verbo que está na raiz da denominação aporetikoi para explicar a designação, sem maiores esclarecimentos $^{79}$. Nota-se, portanto, que Traversari insere uma nova noção para

78 Hi omnes a magistro quidem Pyrrhonii, ceterum a dogmate aporetici \& sceptici, praetereaque \& ephectici, \& zetetici appellabantur. Est enim Zetetica philosophia sic dicta, quod semper in veritatis inquisitione versetur. Porro sceptica, quod simper quearat \& nunquam inueniat. Ephectica autem dicitur ab euentu, quod post inquisitionem ambigatur itidem: Aporetica uero quod eius sectatores semper addubitent. Atque a Pyrrhone Pyrrhonii, ut diximus, denominati sunt. (TRAVERSARI, A. Diogenis Laertii De vita et moribus philosophorum libri 10. Lugduni, 1566, p. 397)

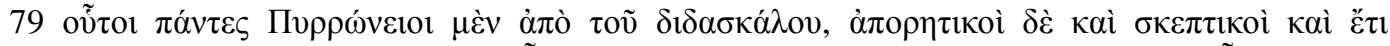

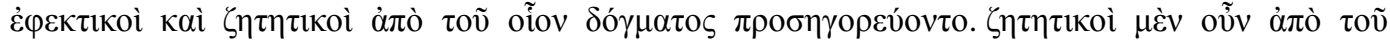


expressar o "estado aporético", e acrescenta não só que os céticos estão "em dúvida", mas que estão sempre em dúvida. E, ainda, exclui da sua tradução uma frase inteira do texto original: "denominam-se aporéticos, pois não apenas eles,

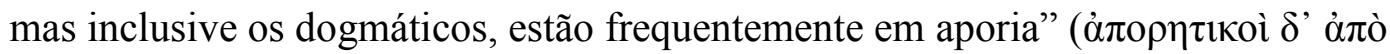

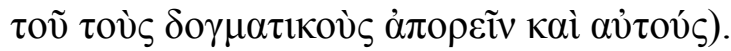

A tradução de Estienne das Hipotiposes Pirrônicas (1562) insere a dúvida logo em seu início. Da mesma forma que Traversari, a dúvida é introduzida logo no terceiro capítulo das Hipotiposes em que Sexto Empírico expõe as quatro "Denominações do Ceticismo" (HP I, 7). Esta é a tradução de Henri Estienne:

A filosofia cética é denominada "zetética" devido à sua atividade de investigar e indagar; "efética", ou suspensiva, devido ao estado produzido naquele que investiga após a sua busca; e "aporética", i.e., dubitativa e hesitante, seja, segundo alguns, devido ao seu hábito de duvidar e investigar a respeito de tudo, ou por conta de que aquele que hesita tem o espírito suspenso entre afirmar e negar; e "Pirrônica", a partir do fato de que Pirro parece ter se dedicado ao ceticismo de forma mais significativa do que seus predecessores.

[Quibus nominus Sceptica institutio vocetur]

Sceptica igitur institutio vocatur etiam Zetetice, sive quaesitoria, ab ipsa actione, quae versatur in quaerendo et utendo Scepsi. appelatur etiam Ephectice, a sustinendo assensu, quae affectio post inquisitionem factam iu eo est, qui Scepsi utitur dicitur et Aporetice, q. d. dubitatoria et haesitatoria, aut inde, quod de re omni dubitet et quaeret, ut nonnulli volunt, aut propterea quod haesitans suspenso sit ad assentiendum aut repugnandum animo. ${ }^{80}$

A expressão “dubitatoria et haesitatoria” é um esclarecimento acrescentado por Estienne, que não corresponde a nenhuma frase no original, sendo

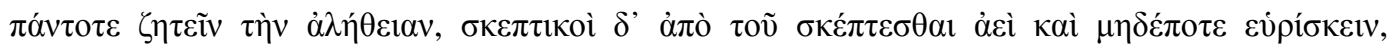

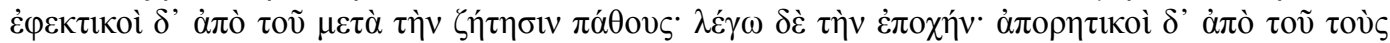

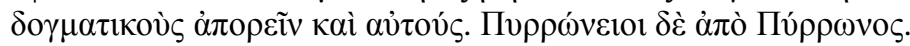

80 STEPHANI, H.; HERVET, G. Sexti Empirici Opera Graece et Latini. Leipzig: Sumptu Librariae Kuehnianae, 1841. No texto Grego referente à mesma passagem lê-se apenas: "ПEPI

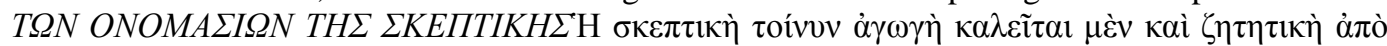

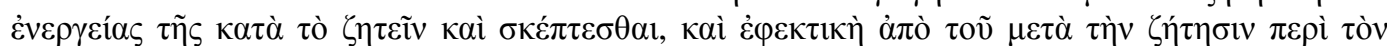

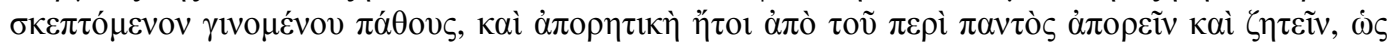

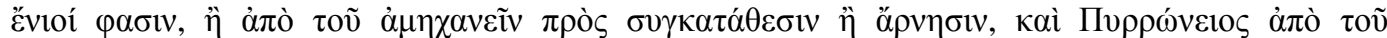

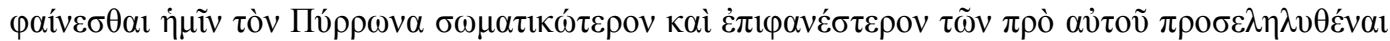
$\tau$ ก̣ $\sigma \kappa \varepsilon ́ \psi \varepsilon 1 "$. Nota-se que a tradução de Estienne continua a ser utilizada atualmente, sem maiores esclarecimentos, sendo amplamente seguida por Bury (1911, p. 5) em sua tradução das Hipotiposes para o Inglês, onde no mesmo trecho se lê: "e aporética, ou dubitativa, seja, segundo alguns, devido ao seu hábito de duvidar e de buscar, ou devido à sua indecisão quanto à afirmação ou negação" (grifos nossos). 
exclusivamente de sua autoria ${ }^{81}$. Segundo Sexto Empírico, há quatro denominações para a escola cética, que de certa forma podem ser entendidas como equivalentes: céticos, eféticos, aporéticos e pirrônicos. Estienne, no entanto, acrescenta ao entendimento da denominação dos céticos como "aporéticos" (aporetikoi) o sentido de "dubitativos e hesitantes". Portanto, na medidade em que na tradução de Estienne a filosofia cética é considerada "aporética" por ser “dubitativa e hesitante [seja] devido ao seu hábito de duvidar e investigar a respeito de tudo, ou por conta de que aquele que hesita tem o espírito suspenso entre afirmar e negar", a dúvida e a hestitação tornam-se equivalentes ao próprio ceticismo. No capítulo "Sobre os princípios do Ceticismo" (HP, I, vi, 12), Sexto afirma que

Homens de talento, perturbados pelas contradições nas coisas e em aporia a

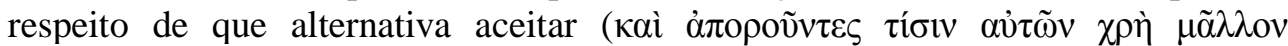
$\sigma v \gamma \kappa \alpha \tau \alpha \tau i ́ \theta \varepsilon \sigma \theta \alpha \mathrm{l}$ ), foram levados a indagar sobre as coisas verdadeiras e sobre as falsas, esperando encontrar a tranquilidade ao resolver esta questão.

$\mathrm{Na}$ tradução de Estienne da mesma passagem, os homens de talento estão em dúvida a respeito de qual alternativa $\operatorname{aceitar}^{82}$. Os céticos não mais adotariam o "princípio do ceticismo" por conta da aporia em que caem, em sua investigação da anomalia das coisas, a respeito de qual alternativa adotar, mas, por conta da anomalia observada, passam a duvidar "sobre as coisas verdadeiras e sobre as falsas, esperando encontrar a tranquilidade ao resolver esta questão". A atividade do cético, portanto, não mais seria a investigação, mas a atitidade dubitativa: o cético perde seu sentido original, encontrado até mesmo na etimologia do termo (skepsis) - o cético não mais seria aquele que investiga, que "persiste em sua busca", mas que duvida. Este modo de conceber o ceticismo se tornaria lugar comum no século XVII, inclusive devido à imensa influência de Montaigne e sua releitura do ceticismo. Nas palavras François de La Mothe Le Vayer, referindo-se

81 ver Olaso, 1975.

82 "Siquidem adundantia quadam ingeniii praestantes homines, quum ob eam inaequalitatem, quae in rebus erat, turbarentur, \& quibus potius assentiendum esset, dubitarent: quid in rebus verum, quid falsum esset, quaerere coeperunt: ut ex horum dijudicatione illum mentis imperturbatum statum adepturi". 
aos seguidores de Pirro na seção intitulada "Sobre Pirro e a seita cética" em $D a$ Virtude dos Pagãos (1642):

Seus seguidores não foram somente chamados de pirrônicos por causa de seu nome, eles tiveram três ou quatro outros que se relacionam todos, segundo sua etimologia, às dúvidas de que esses filósofos faziam profissão em sua busca contínua da verdade. É por isso que são chamados de eféticos, zetéticos, aporéticos e ainda mais comumente céticos, as quais são apelações sinônimas que lhes foram dadas de maneira quase indiferente, como marca de uma irresolução particular deles.

A noção de dúvida passaria tanto a ser equivalente ao próprio significado do ceticismo, quanto a estar na origem do ceticismo: ao observar a anomalia nas coisas, o cético é levado a duvidar. Neste sentido, o ceticismo se deveria ao estado de dúvida não poder ser dissolvido, ao passo que, segundo Sexto, o que é aporético e indecidível são as anomalias nas próprias coisas, bem como os conflitos e disputas que os filósofos se enredam em torno delas. Por seu turno, a epoche (suspensão) passa a ser uma decorrência da dúvida e da hesitação, pois aquele que hesita tem "o espírito suspenso entre afirmar e negar". O cético transforma-se em um indivíduo que duvida de tudo e cujo espírito está sempre indeciso e hesitante - sendo inclusive, como veremos em Montaigne, a sua tarefa e e o seu ofício buscar estar em constante dúvida e perplexidade. É notável que é este entendimento do ceticismo que mais frequentemente se encontra na modernidade ${ }^{83}$. No período moderno, a dúvida expressa a própria identidade e significância do ceticismo.

Deste modo, a "dúvida" pode ser considerada a característica principal do cético na modernidade, de modo que a introdução da noção de dúvida pode ser

83 Cabe assinalar que, além de estar ausente dos textos de Sexto Empírico e Diógenes Laércio, a dúvida é introduzida nas traduções modernas em uma posição central. A noção de dúvida é tornada equivalente a termos técnicos fundamentais do ceticismo, inclusive tomando o lugar de uma das próprias denominações do ceticismo. Deste modo, pode-se afirmar que a tradução dos aporetikoi como "aqueles que duvidam" (addubitant) ocupa uma posição de destaque consideravelmente maior do que o dubitari no tratamento de Cícero do pensamento da tradição acadêmica. A "capacidade de duvidar de si" para Cícero é uma característica distintiva da filosofia acadêmica, que a torna mais íntegra e livre do que a filosofia dogmática. 
considerada um dos elementos centrais da transformação do ceticismo no período moderno. Como escreve Naya (2001, p. 14):

A dúvida é para o Renascimento um dos rótulos que melhor definem o Pirronismo. É notável ver que a denominação quádrupla da escola cética incorpora este termo, sendo os aporètikoi apresentados como aqueles que duvidam (addubitant) desde 1432 na tradução de Diógenes Laércio por Ambrogio Traversari; o termo é incluído na quádrupla denominação de Sexto, tanto na tradução de Estienne quanto na tradução de Hervet, um século e meio mais tarde: a aporia que faz parte do exercício do cético passa a ser na cultura ocidental moderna uma dubitatio.

A dúvida pode ser considerada a marca principal da transformação do ceticismo no período moderno. Pode-se ver que a interpretação do ceticismo através da noção de dúvida é uma constante na releitura moderna do ceticismo. Isto indica que já havia uma presença marcante da noção de dúvida na "consciência moderna" antes da década de 1560, a qual viria então a se manifestar tanto nas traduções das fontes céticas, quanto nas interpretações do ceticismo algumas das quais veremos a seguir.

\section{2}

\section{A Reforma Protestante}

Em O Elogio da Loucura (1511), motivado por um espírito de antiintelectualismo, Erasmo pronuncia-se a favor dos "Acadêmicos" contra a presunção e precipitação das asserções dogmáticas. No mesmo sentido, a única menção que Erasmo faz ao ceticismo em De libero arbitrio (1524) ocorre ao explicar o seu sentimento de "desagrado por asserções":

Tão longe estou de deleitar-me em asserções, que prontamente tomaria refúgio na opinião dos céticos, onde isto é permitido pela autoridade inviolável das Escrituras 
e pelos decretos da Igreja, à qual em todo lugar submeto os meus sentimentos pessoais, queira apreenda ou não o que prescreve. ${ }^{84}$

Esta referência de Erasmo aos céticos dá-se no contexto do questionamento da sua própria capacidade de apreender as Escrituras. Após afirmar que muitas passagens da Bíblia são obscuras, algumas ao ponto de não poderem ser penetradas pelo intelecto humano, Erasmo sugere que se deveria evitar discuti-las avidamente ou sustentar posições fortes a seu respeito. A resposta de Lutero em De servo arbitrio (1525) encontra-se na seção intitulada: “A certeza que provém da fe̋", onde se pode ler que "nada é mais bem conhecido ou mais comum entre cristãos do que a asserção", e ser assertivo é uma exigência que advém da natureza do Cristianismo:

Permita-nos sermos assertivos, devotados à asserção e deleitarmo-nos nelas, enquanto tu permaneces com os seus Céticos e Acadêmicos até que Cristo te convoque também. O Espírito Santo não é nenhum Cético, e não são dúvidas ou meras opiniões que ele imprimiu em nossos corações, mas asserções mais seguras e certas do que a própria vida e toda a experiência ${ }^{85}$.

Com esta resposta, pode-se notar que o movimento de Lutero em rejeitar os “Céticos e Acadêmicos” se dá no sentido de afastar igualmente a possibilidade da dúvida, e resguardar a garantia de certeza da verdade religiosa. Nota-se que o critério da consciência individual de Lutero tem uma inspiração agostiniana: com base na fé, a razão seria capaz de alcançar a verdade, sendo iluminada pelo Espírito Santo em uma experiência de interioridade ${ }^{86}$. Como a verdade revelada ocorre através de uma experiência interior, em que é sentida como uma "certeza subjetiva", negar a possibilidade de certeza significa, para Lutero, o mesmo que a

84 De libero arbitrio, prefácio.

85 De servo arbítrio, II.

86 Para Agostinho, a verdade revelada, recebida através da iluminação divina, é o critério de verdade. Em De Magistro, afirma que "Cristo é o mestre da vida interior", sendo no domínio da interioridade, da experiência da fé, que a verdade é iluminada. 
negação da verdade religiosa. Deste modo, nada menos do que uma certeza completa seria capaz de satisfazer a Lutero: como a certeza é concedida pela graça divina, a dúvida e a incerteza poderiam ser consideradas equivalentes à ausência de fé.

Erasmo, ao contrário, considera a certeza completa um ideal exagerado diante da fraqueza das capacidades humanas. Deus não nos criou ou projetou as faculdades do espírito humano de modo a sermos capazes de perscrutar os abismos insondáveis da Sua criação, da Sua essência, e tampouco das Escrituras, de modo que seria recomendável uma postura de "não asserção" diante de tais limites da condição humana. Portanto, Lutero insiste que a verdade religiosa seja dotada de uma certeza completa, ao passo que Erasmo sustenta que tal certeza não seria possível, de modo que asserções radicais a este respeito deveriam ser evitadas.

Erasmo afirma que, se autorizado, subscreveria à posição dos céticos. Assinala a limitação da razão em conhecer o mundo, inclusive certas passagens da Bíblia seriam obscuras demais, de modo que não seríamos capazes de entender o seu significado em toda a sua profundidade. Se isto demonstra uma atitude cética de Erasmo, por outro lado, o seu "ceticismo" está diretamente ligado à tradição do anti-intelectualismo cristão e a uma postura de humildade intelectual. Deste modo, é difícil interpretar a atitude de Erasmo, pois claramente parece sustentar uma atitude cética, como se pode ver em seu "desagrado por asserções" e em sua assunção de que “de bom grado subscreveria à posição dos Céticos". Contudo, a postura de Erasmo poderia ser pensada ainda de diversas formas: revelar uma postura anti-intelectual ou cética, estar em conexão com a defesa de um ideal humanista de liberdade, ou mais diretamente com o seu compromisso com a unidade da religião católica. Em seu debate, Lutero e Erasmo fazem referência aos "Céticos" e "Acadêmicos", mas de que modo seria o ceticismo entendido por eles?

De acordo com Schmitt, as referências feitas ao ceticismo na querela sobre o livre-arbítrio não indicam que haveria uma presença importante das ideias céticas 
antigas na origem das controvérsias da Reforma. Embora possa subscrever à tese de Popkin de que a Reforma teria desempenhado um papel especial para a "entrada" do ceticismo no pensamento moderno, Schmitt (1972, p. 58) mostra-se mais cauteloso em atribuir ao ceticismo um papel decisivo em suas controvérsias religiosas:

Apenas em parte estavam os textos céticos antigos na raiz dos debates da Reforma e seria errado enfatizar demasiadamente a sua importância, especialmente durante os anos iniciais em que as tendências principais da disputa se delinearam. $\mathrm{O}$ ceticismo filosófico tornou-se uma questão importante no debate religioso, especialmente após as ideias céticas antigas mais importantes terem recebido ampla distribuição com a publicação das traduções para o latim das obras de Sexto Empírico (1562; 1569).

Nota-se que Schmitt não nega que houvesse a presença de textos céticos desde os anos iniciais ou na raiz dos debates da Reforma, nem que eles possam ter desempenhado alguma influência. Entretanto, indica que, se houvessem desempenhado uma influência significativa, isto teria ocorrido somente após a década de 1560, com a publicação das traduções de Sexto Empírico por Stephanus e Hervet. Como assinala Popkin, o ceticismo viria a ser influente apenas em um período posterior, quando as controvérsias se intensificam, especialmente durante os debates entre os defensores da Reforma e da Contra-Reforma ${ }^{87}$.

Pode-se afirmar que as controvérsias da Reforma estavam centradas, portanto, em questões propriamente teológicas, que seriam independentes de fontes céticas, sendo a partir de influências hauridas de outras fontes, e não da retomada do ceticismo antigo, que os modos de formulação e problematização destas controvérsias inicialmente se desenvolvem e tomam corpo. Portanto, as ideias céticas antigas teriam sido incorporadas com mais vigor apenas posteriormente aos debates religiosos da época, mas não estariam dentre as fontes

87 Ver Popkin, 2003, cap. 1, "A Crise intelectual da Reforma". 
principais das controvérsias e não teriam determinado ou influenciado diretamente a problemática na sua origem.

Por outro lado, é notável o modo como as questões da dúvida e da certeza ocupam um lugar central nas controvérsias religiosas da Reforma. Questões como: "posso ter certeza de que minha conduta agrada a Deus?" e "como excluir a possibilidade da dúvida na interpretação das Escrituras e da verdade religiosa?" podem ser consideradas fundamentais. Como afirma Schmitt,

Os problemas da certeza do conhecimento, e das possíveis fontes do conhecimento dotado de certeza estavam constantemente na dianteira das diversas disputas (1972, p.170).

\begin{abstract}
Nota-se que Lutero parece não fazer nenhuma distinção - ao menos nenhuma distinção clara - entre ceticismo e dúvida. O ceticismo parece ser entendido por Lutero como a defesa de uma atitude de dúvida intelectual, e da incapacidade de se obter a certeza. Deste modo, o ceticismo parece ser simplesmente identificado com a dúvida e, portanto, como forma de descrença e fonte para o pecado.
\end{abstract}

A insistência de Lutero na certeza, que determina a sua rejeição do ceticismo, pode ser considerada estar na base da sua concepção religiosa. De acordo com Lutero, o cristão, uma vez que autenticamente possui fé, não deve questionar os sinais de Deus, ou se a sua conduta satisfaz a Deus, e tampouco elaborar estas questões em termos de certeza, i.e., questionar-se, por exemplo, “que certeza se possui de que este é realmente um sinal de Deus?", ou "com que certeza posso saber que a minha vida agrada a Deus?", pois se um homem não tem certeza de que agrada a Deus, então é certo que não o agrada.

Para Lutero, a descrença consiste justamente em se colocar em dúvida a benevolência divina, de modo que é um desejo de Deus que se acredite que Ele nos é favorável com a maior certeza possível (1969, p.309). Deste modo, jamais 
faltaria certeza a quem tem verdadeira fé. Lutero busca esclarecer que a fé é equivalente à certeza, e consequentemente a incerteza equivalente à descrença.

Neste sentido, a questão da certeza está inextricavelmente ligada à temática da fé, e consiste em um dos pontos centrais nas disputas religiosas do século XVI. E, para além da sua conexão fundamental com o próprio entendimento do que seja "possuir fé", pode-se ver que a certeza espalha-se para diversas outras disputas religiosas, como na necessidade sentida por Lutero de estabelecer que, para a Igreja, é impossível errar, na medida em que é divina, e não humana, e está assentada na autoridade das Sagradas Escrituras. Isto, é claro, depende, por sua vez, de que seja estabelecido que o significado das Sagradas Escrituras não seja ambíguo ou obscuro, mas, pelo contrário, que contenha uma "luz espiritual bem mais forte do que o próprio sol". (Lutero, 1969, p.159)

Ao discutir a natureza das leis, Lutero afirma que, mesmo que estejam inseridas em um mundo profano, de valorização das coisas temporais, as leis devem ser dotadas de certeza:

Em todo governo dos povos [...] é a regra que todas as questões de disputa devam ser decididas por meio de leis. Mas como poderiam ser decididas se as leis não possuíssem uma certeza completa e fossem como luzes brilhantes dentre o povo? Pois, se leis são ambíguas e incertas, não apenas não seriam decididas disputas nenhumas, mas tampouco haveria quaisquer normas de conduta certas; pois leis são feitas de modo que a conduta seja regulada de acordo com certo padrão, e, assim, questões de disputa são decididas. Aquilo que é o padrão e a medida de outras coisas, portanto, como a lei o é, deve possuir a maior clareza e certeza de todas. E, se esta luz e certeza nas leis são necessárias, e concedidas livremente ao mundo inteiro pela bondade de Deus, em sociedades profanas que se ocupam de coisas temporais, como é concebível que ele não deva conceder aos seus cristãos, seus eleitos, leis e regras de luz e certeza infinitamente maiores pelas quais possam orientar a si mesmos e decidir todas as disputas, tendo em vista que ele deseja que coisas temporais sejam desprezadas por aqueles que são seus? $(1969$, p.160)

Sendo leis dotadas de certeza uma necessidade para o governo de todos os povos, Deus não deixaria de concedê-las para os seus eleitos, sendo inclusive a vontade divina que os cristãos possuam leis dotadas do grau mais alto possível de "luz e certeza". 
A onda de dúvida que chega ao período moderno conjuntamente à redescoberta do ceticismo antigo é utilizada para interpretar a nova ou recémdescoberta filosofia antiga, e acrescenta-se ao seu entendimento. Contudo, como sugere Schmitt, a sua "atitude cética" pode ter se originado a partir de outras influências, independentemente da tradição cética, e então se confunde e se mistura às suas referências aos "Céticos" e "Acadêmicos".

A obra de Philip Melanchthon (1487-1560) pode ser tomada como um exemplo ilustrativo de como o ceticismo é interpretado no contexto religioso moderno através das noções de dúvida e certeza, bem como, segundo Schmitt, de que o impacto do ceticismo nas disputas da Reforma teria se dado de modo crescente, e não desde os seus anos iniciais. Após Erasmo criticar o tratamento que confere ao ceticismo acadêmico no prefácio de 1535 de Loci communes theologici, é possível notar nas sucessivas edições da obra que Melanchthon pronuncia-se cada vez mais a respeito das questões da certeza e do ceticismo, além de ampliar consideravelmente os seus comentários sobre a dúvida e a suspensão do juízo (especialmente na edição de 1543).

Para Melanchthon, a certeza que caberia à filosofia seria derivada da “experiência universal, de princípios e demonstrações”, ao passo que a certeza própria à doutrina da Igreja adviria da palavra revelada. Deste modo, afirma: "De maneira nenhuma deixemos a dúvida filosófica ou epoche ter entrada na doutrina da Igreja, a qual deriva de Deus" ${ }^{88}$. Segundo Schmitt (1972, p. 62), "para Melanchthon, suspensão do juízo e dúvida, técnicas talvez de alguma utilidade para a filosofia, possuem nenhuma aplicação na 'doutrina da Igreja"”.

Quando o interesse pelo ceticismo filosófico começa a se intensificar, sobretudo a partir da década de 1540, pode-se verificar que este interesse aparece conectado à questão da dúvida e da certeza, e já se pode identificar a interpretação da filosofia cética antiga como uma filosofia correspondente à dúvida como a leitura predominante do período. Nas exposições do ceticismo deste período,

88 Melanchthon, Loci Communes apud Schmitt (1972, p. 61). 
pode-se notar que, quando se refere à "epoche" - seja como retentio assensionis, suspensio judicii, ou no original grego -, a suspensão do juízo e "dúvida" são tomadas como conceitos equivalentes e intercambiáveis, como se possuíssem o mesmo significado. ${ }^{89}$.

A equivalência entre dúvida e ceticismo já é marcante em Melanchthon. No prefácio à edição de 1533, Melanchthon afirma: “Et procul hie repudiandus est Academicorum et Scepticorum mos, qui vetant asserere quicquam, et iubent dubitare de omnibus rebus seu suspendere assertiones". A epoche torna-se equivalente à dúvida. Embora traduzida como suspendere assensiones, Melanchthon entende que a epoche não seria de nenhuma forma diferente de uma atitude dubitativa. Pelo contrário, ao se referir à epoche, aponta justamente para a "característica do ceticismo" de colocar tudo em dúvida: com a sua suspensão, os céticos pretendem colocar tudo em dúvida.

Sendo a certeza exigida por Melanchthon em matéria de verdade religiosa, e a dúvida relacionada à falta de fé (e, portanto, ao pecado), a doutrina dos "Céticos" e "Acadêmicos" da suspensão do juízo precisa ser rejeitada. Na “doutrina da Igreja”, a certeza é garantida pela palavra revelada de Deus. Portanto, a "dúvida filosófica" não tem nela nenhum lugar para ocupar: "Quare illam dubitationem philosophicam seu epoche nequaquam admittamus ad doctrinam Eeclesiae a Deo traditam". 90

Por conseguinte, pode-se encontrar uma forte presença da noção de certeza no início do período moderno, proeminente nas controvérsias religiosas da Reforma - e, como vimos anteriormente, de modo significativo entre os humanistas italianos. Nas controvérsias da Reforma, pode-se observar que ambos os lados em disputa fazem igualmente uso da noção de certeza. A despeito das suas divergências, a certeza é adotada por ambos os lados de suas disputas como um pressuposto comum, sendo um ponto central das suas controvérsias.

89 Melanchthon, Loci Communes apud Schmitt (1972, p. 60).

90 Idem, Ibid. XXI, 6os: apud Schmitt (1972, p. 61). 
Reformadores como Lutero e Melanchthon - e posteriormente Calvino - insistem ferozmente na posse da certeza completa, ao passo que Erasmo assinala a postura de fé e humildade diante do Criador como a mais pertinente para os cristãos.

\section{3}

\section{Montaigne e a Apologia de Raymond Sebond}

As alterações conceituais presentes nas traduções latinas das fontes céticas contêm múltiplas implicações para o significado do ceticismo. Como vimos, Estienne e Traversari traduzem a denominação dos céticos como aporéticos por aqueles que duvidam, e Estienne introduz a noção de dúvida e de hesitação tanto na origem do ceticismo, quanto ao entendimento da epoche nas Hipotiposes, propiciando a transformação do significado do ceticismo ao substituir pelo conceito de dúvida alguns dos principais termos técnicos do ceticismo, como epoche e aporia.

Como buscamos argumentar nos dois últimos capítulos, a centralidade da noção de dúvida para as reinterpreta o ceticismo não deriva exclusivamente das traduções latinas das fontes céticas, mas, pelo contrário, esta centralidade é sinal de como a noção de dúvida já havia se tornado filosoficamente importante. Com Montaigne, a dúvida permanece sendo o modo principal através do qual o pensador francês apropria-se e transforma o significado do ceticismo. $\mathrm{Na}$ Apologia de Raymond Sebond (1580), pode-se ver que a transformação do ceticismo é levada às últimas consequências. Montaigne insere a dúvida em todas as etapas do procedimento cético, de modo que reconcebe o ceticismo, do começo ao fim, através da noção de dúvida, transformando o "cético" por completo em um "indivíduo que duvida". 
Montaigne parece ter conhecido apenas a edição de Estienne (1562) das Hipotiposes Pirrônicas, pois em nenhum momento refere-se ou cita passagens dos Adversus Mathematicos. Também parece não ter tido acesso a um manuscrito original de Sexto; as expressões gregas que cita na Apologia e estão inscritas em sua librairie são provavelmente tiradas da sua cópia em grego das Vidas de Diógenes Laércio (editio princeps, 1533). É, portanto, sobre a tradução de Henri Estienne das Hipotiposes, Diógenes Laércio e Cícero que Montaigne se apoia para a sua "apresentação enérgica" (Popkin, 2003, p. 26) do ceticismo na Apologia de Raymond Sebond.

Popkin sugere que Montaigne tenha passado por uma "crise pirrônica" 91, a qual determinaria a sua posição filosófica na Apologia. Esta expressão é tomada de empréstimo de Pierre Villey (1933), segundo o qual a Apologia teria sido escrita entre os anos de 1576 e 1580, portanto, não só de uma vez, mas tendo passado por significativas revisões previamente à sua publicação em 1580. Em 1576, Montaigne encomenda uma medalha com o desenho de uma balança em estado de equilíbrio, abaixo da qual estão gravados o seu nome e sua idade na ocasião (42 anos). Dentre outros motivos que teria para fazer esta medalha, Villey afirma que Montaigne teria sofrido uma "crise de ceticismo" (1533, p. 294) no período, e que "no início de 1576 a crise da dúvida de Montaigne teria atingido a sua plenitude" (1933, p. 299).

A despeito de se houve realmente uma crise cética pessoal de Montaigne, pode-se afirmar que o teor da Apologia é marcadamente religioso e moral. Embora ressalte a influência da filosofia cética antiga na Apologia de Raymond Sebond, na qual se podem encontrar por volta de vinte e cinco a trinta empréstimos diretos das Hipotiposes, Villey esclarece que em pouquíssimos outros lugares há referências a Sexto Empírico nos Ensaios, de modo que Montaigne não mais parece ter se ocupado com o estudo do ceticismo após

91 Ver Popkin (2003), cap. 3, e Paganini (2012). 
$1580^{92}$. (1933, p. 218). E, ao mesmo tempo, Villey (1933, p. 78) assinala que há vinte e seis empréstimos da Bíblia na Apologia, os quais teriam como "objetivo mostrar que a dúvida não é de modo algum contrária ao espírito da religião". Da mesma forma, Floridi (2002, p. 48) frisa que as interpretações do ceticismo na época consistiam sobretudo em leituras éticas e religiosas: "Montaigne estava alinhado ao seu tempo. O que se pode dizer na verdade é que, em Montaigne, temas lógicos e epistemológicos começam a emergir, no entanto, ainda dentro de cenário consistentemente pragmático e religioso". De acordo com Villey:

A Apologia não compõe um todo cujas partes estão intimamente ligadas, mas sim proximamente dependentes umas das outras, de modo que o conjunto não foi construído de uma só vez; é sobretudo um vasto quadro onde Montaigne agrupa, à medida que a ele se apresentam, todas as ideias sobre a fraqueza da razão humana (Villey, 1933, p. 365).

Pode-se afirmar ser este um dos temas principais, recorrente na Apologia. A razão humana é fraca demais, envolta demasiadamente em confusão e em conflitos para poder atingir a verdade por seus próprios meios. "O homem é capaz de tudo e de nada" (1979, p. 263); "O homem é, por dentro e por fora, fraqueza e mentira" (1979, p. 279). Pode-se pensar que é em vista propriamente desta visão pessimista ou limitacionista da razão humana que Montaigne afirma serem os céticos os mais sábios dentre os filósofos ${ }^{93}$. Como nada se sabe, nem nada se pode conhecer com nenhum grau de certeza, a sabedoria maior na filosofia seria manter-se indeciso e nada afirmar. E, após analisar praticamente toda a tradição filosófica antiga, na qual Montaigne identifica um constante reconhecimento da ignorância, sua conclusão é a de que "a natureza não passa de uma sombra vã e confusa" (1979, p. 249). Em vista da fraqueza do nosso espírito, da ignorância em

92 Embora faça numerosas ampliações à Apologia e outros ensaios na edição de 1588, quando há a publicação do Livro III dos Ensaios.

93 "Não há razão que não possua uma razão contrária, diz o partido mais sábio dos filósofos" (Montaigne, 1979, p. 286: II, 15 [com alterações]). 
nosso suposto conhecimento, devemos ter uma postura de maior humildade. Lança, então, o seguinte desafio:

Se um sábio pode ter desilusões, cem homens e nações o podem também, e, em verdade, a meu ver, o gênero humano inteiro se engana há séculos acerca disto ou daquilo. Que certeza podemos alimentar de que por vezes cesse de se enganar e que no século atual não esteja laborando um erro? (II, 12, p. 270-71) ${ }^{94}$

Nota-se que este desafio baseia-se no problema da incerteza. Como podemos saber se todo o nosso conhecimento atual é verdadeiro, e nos assegurar de que nenhum erro a ele se mistura, ou de que estaríamos neste exato momento formando falsas opiniões? A resposta de Montaigne é a de um bom cristão. Ao fỉnal da Apologia, após uma citação a quem não atribui o autor, provavelmente Sêneca, "Vil e abjeta coisa o homem, se não se eleva acima da humanidade", Montaigne conclui com a seguinte recensão:

Não pode tampouco ocorrer que o homem se eleve acima de si e da humanidade, porque só pode ver como seus olhos e apreender com seus próprios meios. Elevarse-á, se Deus lhe quiser dar a mão. Elevar-se-á sob a condição de abandonar seus meios de ação, de renunciar a eles e de se deixar erguer e se elevar unicamente pelos meios que lhe vêm do céu.

Como a razão humana seria fraca e impotente, e capaz de elevar-se da sua miserável condição apenas através da graça divina, o ceticismo dos acadêmicos e

$94 \mathrm{O}$ famoso desafio de Montaigne formulado a partir de uma discussão sobre a astronomia encontra-se mais adiante no texto da Apologia: "O céu e as estrelas foram durante três mil anos considerados em movimento. Todos acreditaram, até que Cleantes de Samos ou, segundo Teofrasto, Nicetas de Siracusa se lembrou de sustentar que a terra é que girava em torno do seu eixo, seguindo o círculo oblíquo do zodíaco; e em nosso tempo Copérnico demonstrou tão bem esse princípio, que dele se vale em seus cálculos astronômicos. Que concluir, senão que não temos que nos preocupar com saber qual dos sistemas é o verdadeiro? Quem sabe se daqui a mil anos outro sistema não os destruirá a ambos? [...] Temos, portanto, quando se apresenta uma nova doutrina, razões de sobra para desconfiar e lembrar que antes prevalecia a doutrina oposta. Assim como esta foi derrubada pela recente, no futuro uma terceira substituirá provavelmente a segunda." (II, 12, p. 268). 
pirrônicos mostra-se como a escola mais sábia da filosofia pagã ${ }^{95}$. Logo após expor o modo de vida de Pirro, escreve: “Um espírito isento de preconceitos é uma vantagem preciosa para a nossa tranquilidade. Quem julga e controla seus juízos não se submete jamais facilmente” (1979, p. 238). Os filósofos dogmáticos têm demasiadas opiniões, e seu orgulho vai de encontro à tranquilidade, bem como, poder-se-ia dizer, à própria Verdade. Sobre os os céticos, Montaigne afirma (1979, pp. 238-39):

Como são dóceis e obedientes às leis políticas os simples de espírito e curiosidade, do que os que investigam e dogmatizam acerca das coisas humanas e divinas. Nada do que concerne ao homem apresenta maior utilidade do que essa simplicidade. Nessa filosofia pirrônica ele aparece nu e vazio, consciente de sua fraqueza natural e suscetível de receber de cima, até certo ponto, a força de que carece. Estranho a todos os conhecimentos humanos, acha-se tanto mais preparado a se tornar um domicílio para a ciência divina; faz abstração de sua própria inteligência a fim de dar maior espaço à fé, crê e não propõe nenhum dogma contrário às leis e aos costumes; humilde, obediente, disciplinado, estudioso, inimigo declarado da heresia, está, portanto livre dessas vãs opiniões contrárias à religião e introduzidas pelas seitas dissidentes; é uma página em branco, preparada para receber tudo o que apraz a Deus nela traçar.

Para Montaigne, o pirronismo abre caminho para a fé cristã. Embora esta seja, de certa forma, uma pintura benevolente do ceticismo, mesmo antes de se analisar os seus detalhes já se podem notar algumas inconsistências e contradições: o cético é "estudioso", e ao mesmo tempo "faz abstração da sua inteligência". No entanto, o cético jamais poderia abstrair "da sua inteligência a fim de dar maior espaço à fé": o uso da inteligência natural é um guia prático para o cético, e consiste justamente em um dos critérios do ceticismo (HP I, 26). Ainda, em que momento e por quais motivos o cético pirrônico atestaria a sua "fraqueza natural'? E, é claro, pode-se perguntar: por que o cético antigo não enxergaria na fé cristã apenas mais uma série de dogmas sobre objetos não evidentes, acerca dos quais colocaria em prática o seu ceticismo?

95 Nota-se que este fideísmo ou modo de se "fazer uso" da filosofia - inclusive do ceticismo encontra-se desde o contexto da Patrística, como por exemplo em Eusébio e São Clemente. 
Portanto, com Montaigne o ceticismo é inteiramente redefinido e transformado, sendo o Cristianismo um dos elementos principais a partir do qual esta transformação é efetuada. O ceticismo é utilizado como uma "limpeza de terreno": ao derrubar todos os dogmas e "preconceitos" junto consigo mesmo, abre o caminho para a fé ${ }^{97}$. O lema fideísta é a seguinte passagem da epístola de São Paulo aos coríntios, citado frequentemente no período moderno neste contexto, não sendo Montaigne uma exceção (1979, p. 236):

“destruirei a sabedoria dos sábios e rejeitarei a inteligência dos inteligentes". Onde está o sábio do século? E o censor? Onde está o homem culto? Não reduziu Deus a zero a sabedoria humana? Pois em não chegando o mundo ao conhecimento de Deus pela ciência, prouve a Deus que, pela prédica dos ignorantes e dos simples, fossem salvos os crentes.

Ao mesmo tempo em que Montaigne opera esta interpretação cristã do ceticismo, reconfigura-o inteiramente através da noção de dúvida. Com Montaigne, a dúvida é inserida no ceticismo em sua totalidade. Deste modo, a posição de destaque que Popkin (2003) atribui a Montaigne, como sendo o principal responsável pela difusão das ideias céticas antigas após as publicações de Sexto na década de 1560, vale também para o legado do ceticismo como equivalente a uma "doutrina da dúvida".

Todas as mudanças fundamentais no modo de se interpretar o ceticismo já podem ser encontradas em Montaigne (ver Paganini, 2008, 2011). O tratamento do ceticismo na Apologia pode ser tomado como o ponto de confluência de um século e meio de tentativas de compreender o ceticismo no início do período moderno através da noção de dúvida. Montaigne reúne e aprofunda as leituras do cético como quem duvida em um todo unificado, de modo que, através da leitura da Apologia, é possível entender o cético referindo-se quase exclusivamente à noção de dúvida e seus correlatos.

97 Pode-se encontrar o uso da filosofia, e do ceticismo em particular, como preparação para a fé desde a Patrística grega e latina. A respeito do "fideísmo cético" no período moderno, ver Popkin (2003) e Maia Neto (1994). 
Na Apologia, pode-se verificar a presença da dúvida na exposição de todas as etapas do procedimento cético (skeptike agoge): a dúvida torna-se, a um só tempo, a "tarefa", a "regra" e a "finalidade" do ceticismo. Montaigne não se refere à quádrupla denominação cética $(H P$ I, 7) na Apologia, e não refere-se à denominação cética aporetikoi, que Traversari e Estienne traduzem por "aqueles que duvidam", mas tampouco menciona em nenhum momento na Apologia o termo "aporia". Embora faça uso frequentemente da metáfora da balança, a apresentação do ceticismo oferecida por Montaigne não leva em conta a noção de "conflito equipolente", de modo que a noção de aporia não é relevante para Montaigne, sendo excluída e substituída pela noção de dúvida. Por outro lado, Montaigne refere-se às noções de epoche e ataraxia, contudo, alterando a sua significância.

Montaigne inicia a sua apresentação da filosofia cética com uma paráfrase das primeiras linhas das Hipotiposes, em que Sexto descreve "a principal diferença entre os sistemas filosóficos”. Após a sua apresentação das três variedades filosóficas de acordo com Sexto, Montaigne (II, 12, 505) passa a interpretar esta distinção ao seu modo:

Pirro e outros Céticos ou Eféticos [...] dizem que estão ainda em busca da verdade. Estes julgam que os que acreditam tê-la descoberto laboram em profundo erro, e os que afirmam não serem as nossas forças capazes de alcançá-la são, embora em menor grau, demasiado temerários ainda em sua asserção, pois determinar em que medida podemos conhecer as coisas e ajuizar da dificuldade de tal conhecimento é ciência tão elevada, ultrapassando a tal ponto qualquer outra, que duvidam que o homem esteja em condições de possuí-la.

Para Montaigne, os acadêmicos teriam concluído "pela fraqueza e ignorância do homem", ao passo que, para os pirrônicos, conhecer os limites da própria ignorância já seria marca de "ciência elevada", a qual os Pirrônicos 
colocariam em dúvida ${ }^{98}$. Mais adiante, Montaigne passa a interpretar a divisão tripartite da filosofia através do eixo dúvida e certeza:

Eis como entre as três seitas gerais da filosofia, duas professam expressamente a dúvida e a ignorância (les deux font expresse profession de dubitation et d'ignorance); quanto à terceira, a dos dogmáticos, é fácil verificar que, em sua maioria, seus adeptos optaram pela certeza por presunção. (1979, p. 239)

Enquanto Sexto Empírico opõe a escola cética tanto à dogmática quanto à acadêmica, pois estas duas seriam ambas dogmáticas na medida em que chegam a uma conclusão definitiva para o que investigam (a primeira afirma estar na posse da verdade, enquanto a última afirma não ser possível conhecê-la). Deste modo, opõe aos dogmáticos tanto pirrônicos quanto acadêmicos: os dogmáticos “optaram pela certeza"; acreditam ser possível estar na posse da certeza em seus conhecimentos, ao passo que tanto os céticos quanto os acadêmicos "professavam explicitamente a dúvida”.

Portanto, Montaigne não transmite, mas reconcebe o modo de se pensar as variedades ou tipos de filosofia da narrativa de Sexto. Com Montaigne, os filósofos se dividem entre "professar a dúvida" e "optar pela certeza". Pirrônicos e Acadêmicos renunciaram à certeza e optaram pela dúvida, assim tornando-se ambos "céticos". Nota-se que Montaigne não apenas insere a dúvida nas denominações do ceticismo, como Traversari e Estienne haviam feito em suas traduções, e La Mothe Le Vayer viria a fazer, mas altera o próprio critério de demarcação: não só os céticos são aqueles que duvidam, mas é por isso que se distinguem dos dogmáticos e, nesta medida, também os Academicos seriam "céticos".

98 Não se pode encontrar em Sexto Empírico esta forma de conceber a diferença entre as escolas filosóficas, nem a discussão sobre a dificuldade de uma "ciência dos limites". Contudo, há paralelos possíveis em Cícero. Embora Montaigne cite Lucrécio no propósito de demonstrar a dificuldade de tal ciência, a mesma objeção já havia sido levantada por Cícero nos Academica,sendo inclusive formulada de modo similar. Comparar com Acad. II, 92. 
Desde o início da sua exposição do ceticismo, Montaigne o concebe como equivalente à dúvida e é nestes termos que o elogia. Os dogmáticos afirmam conhecer e possuir a certeza, mas o fazem apenas por presunção: se lhes coubesse uma dose maior de humildade, talvez pudessem também confessar um pouco da sua ignorância. Em contraposição à certeza dogmática, a dúvida é dotada de um sentido positivo, e Montaigne a recomenda em diversas ocasiões ao longo da Apologia.

A integridade intelectual acadêmica, de acordo com a qual se é livre para filosofar, e se está desimpedido de compromissos definitivos com escolas e doutrinas filosóficas, e, portanto, livre para escolher entre diversas correntes de pensamento e aceitar o que lhe parece verossímil e apropriado também pode ser pensada como a postura intelectual de ser livre para escolher nenhuma corrente de pensamento, e estar desimpedido para declinar a todas em conjunto. Logo, o ceticismo pode ser facilmente entendido em conexão com a humildade intelectual e até com a piedade, Entretanto, como legitimar uma "filosofia da dúvida" em um ambiente intelectual católico? Em seguida, ao esclarecer qual seria a "tarefa dos pirrônicos", pode-se ver o desdobramento da noção de adiamento ou "retenção do juízo" para Montaigne:

A ignorância que se conhece, que se julga e se condena, não é uma ignorância completa. Para que o fosse, seria preciso que se ignorasse a si mesma. De modo que a tarefa (profession) dos pirrônicos consiste em oscilar (branler), duvidar e investigar, sem afirmar nem assegurar. Das três ações do espírito, a imaginativa, a apetitiva e a anuente (consentente), eles aceitam as duas primeiras; a última, eles a sustentam e a mantêm em situação ambígua, sem inclinação ou aprovação a uma ou outra parte, por menor que seja $(1979$, p. 237 - 2.12.502 [tradução com alterações])

Esta passagem ocorre após Montaigne referir-se ao relato de Zenão utilizava os seus punhos como metáfora para ilustrar a phantasia kataleptike (cf. Acad., II, 145). Deste modo, é propriamente a noção de assentimento (synkatathesis) à que Montaigne se refere e que os céticos manteriam em "situação ambígua". 
Por que o assentimento do cético mantém-se ambíguo? Vemos aqui a transformação da noção de suspensão (epoche). Primeiramente, esta é entendida não propriamente como suspensão, interrupção do ato ou da faculdade de julgar, mas como retenção, sustentação ou manutenção do assentimento em um estado ou situação de ambiguidade. E, desta forma, o assentimento não é suspenso ou interrompido, mas se mantém, se sustenta, é retido. "Não afirmar nem assegurar" designa não um ato de ruptura ou suspensão, mas assinala uma indecisão. A tarefa dos pirrônicos é oscilar, duvidar e investigar, sem afirmar nem assegurar, mantendo o seu assentimento em situação ambígua. Como sustenta o assentimento em uma situação ambígua, pode-se afirmar que, para Montaigne, o cético se situa entre a afirmação e a negação. Por não querer ou por não saber se decidir, o seu espírito oscila entre qual parte conferir o assentimento. $\mathrm{O}$ assentimento do cético não está mais "em suspenso", mas indeciso e hesitante.

A dúvida e a oscilação consistem na tarefa do cético. Portanto, o ceticismo não deve ser pensado como a confissão de uma "ignorância completa". Esta não conhece a si mesma, ao passo que o cético, enquanto indivíduo cuja tarefa é duvidar, coloca em dúvida até mesmo a sua própria ignorância. Para ser coerente, portanto, o cético deve sempre duvidar, pois, ao se manter em um estado de dúvida, distingue-se tanto do dogmático, quanto da ignorância completa. Portanto, de acordo com Montaigne, entende-se que o cético é um indivíduo que se caracteriza por estar em um estado de constante oscilação do espírito. É a oscilação, a dúvida e a indecisão que caracterizam o ceticismo e compõem a sua tarefa, não a suspensão. Ao citar as frases céticas ${ }^{99}$, Montaigne refere-se à frase "epecho" (eu suspendo) ${ }^{100}$.

Seus modos de falar são: Nada estabeleço; não é mais assim que de outro modo, ou nem um nem outro; não compreendo; as aparências são iguais para todos; a lei de falar pró e contra é a mesma. Nada parece verdadeiro que não possa parecer falso. Sua palavra sacramental é epecho, isto é, "sustento, não me movo" (je soutiens, je

99 Ver HP I, 187-209.

100 Ver HP I, 196. 
ne bouge). Eis seus estribilhos. Seu efeito é um puro, inteiro e o mais perfeito adiamento e suspensão do juízo (surceance et suspension de jugement). Eles se servem da sua razão para investigar e debater, mas não para decidir (arrester) e escolher. Quem imaginar uma perpétua confissão de ignorância, um juízo sem inclinação em qualquer ocasião, concebe o pirronismo. (Montaigne, 1979, p. 248: II, 12, 527 [tradução com alterações]).

Como isso, nota-se que a suspensão torna-se um adiamento, atraso ou cancelamento da decisão (surceance). Neste sentido, a epoche passa a significar simplesmente a prática de duvidar e de confissão da ignorância, e não parece fazer diferença sobre o que exatamente se confessa ignorar. O cético simplesmente duvida e suspende, adia o julgamento do seu espírito e confessa a sua ignorância. Este é o seu procedimento. Não parece levar a nada, nem significar muita coisa: o cético apenas demonstra "um juízo sem inclinação, em qualquer ocasião". Segundo Montaigne, as frases céticas demonstram que, para expressar a sua posição, o cético precisaria de uma "nova linguagem":

Os filósofos pirrônicos não podem expressar a sua concepção geral por nenhum modo de falar; pois lhes seria preciso uma nova linguagem: a nossa é toda ela formada de proposições afirmativas, que lhes são em tudo inimigas. De modo que, quando dizem: "eu duvido", poderíamos objetar que incorrem em contradição, pois ao menos se asseguram e sabem disto, que duvidam. Assim, para evitar semelhante objeção, tiveram de tomar de empréstimo esta comparação da medicina, sem a qual o seu estado de espírito (humeur) seria inexplicável: ao proferirem "eu ignoro", ou "eu duvido", acrescentam que ambas as proposições desaparecem com o resto da frase, assim como o ruibarbo expele os humores e com estes a si mesmo. Tal estado de espírito enuncia-se interrogativamente de maneira mais segura, dizendo-se "Que sei eu?". E é minha divisa. E a acompanho de uma balança. (Montaigne, 1979, p. 248).

No entanto, os pirrônicos jamais dizem "eu duvido". Não existe tal fórmula no ceticismo pirrônico. Nos termos em que Montaigne coloca o problema, pode-se pensar que a necessidade de uma nova linguagem consiste em que a nossa não é capaz de expressar o paradoxo e a contradição. Pois, como os céticos são aqueles que duvidam de tudo, pode-se dizer que, fundamentalmente, duvidam de si mesmos, e, caso necessário, duvidam até mesmo do fato de que duvidam. 
Entendida como dúvida e como ato de retenção, sustentação ou manutenção do assentimento, em vez de propriamente suspensão, a epoche não mais tem o significado cético de "suspender-se", pois parece simplesmente referir-se a um indivíduo que não confere o seu assentimento, mas o retém. Deste modo, a epoche assinala tão somente o adiamento do assentimento, um atraso na decisão. A epoche, em vez de indicar a suspensão do espírito diante de um conflito, passa a significar a retenção do assentimento no espírito, nele "detida" em sua indecisão e hesitação, logo não sendo capaz de conferir o assentimento. Para Montaigne, o cético está indeciso; apenas o seu juízo ou "espírito" está em suspensão. Eis como, na exposição de Montaigne, a epoche levaria à ataraxia:

Essa atitude do seu espírito, reta e inflexível, considerando os objetos sem aplicação nem consentimento, encaminha-os para a ataraxia, estado de alma (condition de vie) sereno e tranquilo [...]. Com efeito, um tal estado de espírito os isenta inclusive da intransigência em relação à sua doutrina, que defendem apenas, não receando serem vencidos em suas discussões. Se disserem que o que é pesado cai, aborrece-os nossa aquiescência, e buscam que se lhes contradiga, para engendrar a dúvida e o adiamento do juízo (pour engendrer la dubitation \& surceance de jugement), que é o seu fim. (Montaigne, 1979, p. 237: II, 12, 503 [com alterações]).

A retenção do consentimento leva o cético à ataraxia, contudo, o seu fim é “a dúvida e o adiamento do juízo". Como podem a dúvida e a indecisão levar à tranquilidade? Ao se entender a epoche como dúvida, decorre a dificuldade extrema de se aceitar que a epoche cética possa levar à ataraxia. Com isto, a concepção do ceticismo como um modo de vida cai por terra, e se passa a ignorar o contexto próprio do ceticismo como uma escola de pensamento helenística, cujo fim, compartilhado por estoicos e epicuristas, é o bem viver, a tranquilidade e a felicidade. Deste modo, Montaigne pode ser considerado o marco da completa transformação do ceticismo: a sua prática filosófica é transformada no exercício da dúvida, e a sua significância, de uma filosofia prática, um modo de vida com um fim ético, passa a designar uma atitude ou posição relativa ao conhecimento centrada na atividade de duvidar, ou exercício de manter-se em um "estado dubitativo da alma". 
Como escreve Paganini, as "mudanças decisivas precederam o deslocamento que ocorreu com Descartes; elas podem ser atribuídas a Montaigne. Este manteve as objeções epistemológicas fundamentais típicas do ceticismo [...], mas subverteu os seus fins éticos originais" (2011, p. 105). E, nas palavras de Floridi (2002, p. 49):

Após Montaigne, o ceticismo foi cada vez menos interpretado como um modo de vida e uma filosofia ética, vindo a desempenhar o papel de um polo dialético na investigação epistemológica que seria totalmente explorada por Descartes.

Como Montaigne entende que a dúvida é a tarefa do cético e a sua finalidade, não há mais espaço para a ataraxia. Não apenas com Descartes, mas já a partir de Montaigne, a ataraxia é progressivamente deixada de lado das descrições da filosofia cética - passa a ser uma "inconsistência interna" do ceticismo. Pois, não sendo mais a suspensão um índice de sabedoria, tampouco leva à tranquilidade, mas equivale à “abstração da própria inteligência”. A "ignorância que se conhece", uma douta ignorância, deve duvidar inclusive de si mesma, pois, senão, já se saberia ignorante. Portanto, para ser coerente, a dúvida dos céticos deveria ser uma dúvida completa, irrestrita, não deveria possuir limites. O cético, enquanto cético, deve sempre duvidar: o cético deve manter-se em um constante estado de dúvida. Deste modo, pode-se dizer que, já com Montaigne, o cético é quem "duvida por duvidar" pois, afinal, a dúvida constitui o seu objetivo. A sua "dúvida" não tem necessariamente um propósito: buscam a contradição. Nota-se que, com isso, a noção de diaphonia torna-se sem sentido: o cético duvida mesmo na ausência de um conflito ou problema real. Sendo o seu ofício e tarefa, os céticos duvidam a todo custo:

Só avançam as suas proposições no intuito de combater as [proposições] que supõem acreditarem os seus adversários. Se adotamos o seu ponto de vista, defendem de bom grado a tese contrária: não têm preferência. Se dizemos que a neve é preta, argumentam, ao contrário, que é branca; se achamos que não é nem preta nem branca, sustentam logo que é de ambas as cores; se concluímos que não sabemos nada ao certo, esforçam-se por demonstrar que o sabemos muito bem. E, 
ainda que pelo raciocínio estabeleçamos de maneira evidente estarmos em dúvida, eles discutirão a fim de provar que não há dúvida em nós ou que não poderíamos julgar e estabelecer que duvidamos. (1979, p. 237: II, 12, 503)

Deste modo, tanto a noção de diaphonia (contradição) quanto a de isosthenia (oposição) perdem seu sentido na Apologia. O cético, é claro, não avança proposições ou defende o seu "ponto de vista", contudo, a própria prática dialética do ceticismo é enfraquecida na exposição de Montaigne. Ao entender que duvida apenas por duvidar, sem nenhum sentido ou propósito que "não têm preferência", o cético não pesa realmente argumentos ou busca a equipolência entre eles, mas apenas a constante contradição, fazendo uso de quaisquer meios possíveis, sem ser claro com qual propósito ou intenção o faz, senão a de deixar tudo "duvidoso". Na passagem abaixo, Montaigne refere-se à vantagem dos pirrônicos na argumentação:

\begin{abstract}
Assim, os pirrônicos levam grande vantagem nas discussões, pois pouco lhes importa os ataques dos adversários, desde que possam atacar também. Tudo lhes serve de argumento; se vencem, nossas razões não têm valor; se ganhamos, as deles é que não prestam; se erram, fica demonstrado que a ignorância existe; se nos enganamos, nós é que fornecemos a prova da sua existência; se conseguem convencer de que nada é certo, confirmam a tese que defendem; se não o conseguem, ei-la naturalmente confirmada: "encontrando o propósito de um mesmo assunto razões idênticas a favor ou contra, é-lhes fácil suspender seu julgamento num sentido ou noutro".
\end{abstract}

No entanto, não se pode ver na sua exposição do ceticismo a argumentação pró e contra. E, ao longo da Apologia, o próprio Montaigne apresenta os infinitos debates da tradição a respeito, por exemplo, de alma, imortalidade, felicidade, contudo, sem avaliar e pesar ambos os lados. Montaigne apenas os acumula. Deste modo, as diferentes teses são rejeitadas não por haver investigado os termos da sua oposição, ou por constatar que estão em equilíbrio. Como escreve Brahami (2012, p. 70), em Montaigne "raramente se encontra um pensamento propriamente equipolente, terminando numa epoche". O acúmulo de diversas teses e doutrinas não é produzido com a intenção de nelas analisar o peso das razões e dos 
argumentos pró e contra. Este acúmulo tem como "efeito buscado, em vez da isosthenia, uma astenia", de modo que "a ideia mesma de colocar na balança é abandonada" (Brahami, 2012, p.72). Portanto, esta é a recomendação de Montaigne:

Deixemos de lado essa infinita confusão de opiniões, que se pode encontrar entre os próprios filósofos, e essa perpétua e universal discussão acerca do conhecimento que temos das coisas, pois é evidente que os homens, e os mais sábios e sinceros, e os mais capazes, não estão de acordo acerca de nada, nem mesmo em que o céu se encontra acima de nossas cabeças, porquanto os que duvidam de tudo duvidam disto também. (1979, p. 264; II, 12, 563).

No lugar da diaphonia, isosthenia a aporia, Montaigne faz uso das ideias de perpétuo conflito e confusão. Encontra-se na tradição apenas o interminável dissenso entre os filósofos. Portanto, seria inútil pretender acompanhar e julgar as controvérsias:

Ainda que se adote o melhor partido, nunca será ele tão seguro que não se faça necessário, para defendê-lo, atacar e combater centenas de partidos contrários. Não será melhor ficar de fora da confusão? $(1979$, p. 237)

Ao tentar julgar qual seria o melhor partido, nosso julgamento cairia em um movimento de perpétua mudança e flutuação, sem ser possível jamais encontrar um solo firme:

Além dessa inumerável diversidade de opiniões, é fácil verificar, pela confusão em que nos joga e a incerteza que todos sentem, que o nosso julgamento não tem um fundamento sólido. Quantas vezes julgamos diversamente as coisas? Quantas vezes mudamos de ideias? [...] E, no entanto, ainda que o destino nos leve a mudar quinhentas vezes de ideia, a última, atual, será a verdadeira, a infalível. (1979, pp. 264-65, II, 12, 563). 
Como a experiência do pensamento é a experiência de um movimento de constante flutuação, "não são somente os conteúdos que flutuam, é a mente mesma que está em fluxo" (Brahami, 2012, p.72). E, como a última opinião que está presente na mente predomina, não é possível a argumentação pró e contra. Todos sentem a incerteza, a inconstância, sentimentos aos quais se conecta a impossibilidade da investigação in utramque partem. Não é possível buscar uma isosthenia nas controvérsias infinitas da filosofia; nestas encontra-se apenas confusão e incerteza. O próprio fato de haver essa "inumerável diversidade de opiniões" a respeito de inúmeras controvérsias seria motivo suficiente para nos dissuadir a tentar decidi-las:

Se o fundamento está ausente, o seu discurso cai por terra; discutir e investigar não têm outro objetivo senão os princípios; se não os atinge, tudo é lançado a uma irresolução infinita. (1979, pp. 263, II, 12, 561[tradução com alterações]).

O espírito vacila, hesita entre as diferentes teorias sempre se fixando na última com a qual se depara, entregando-se, a cada vez, "por inteiro" neste incessante movimento. Com isso, Montaigne esvazia a noção de aporia e, ao fazêlo, é a indecisão e a irresolução que em Montaigne têm uma significância fundamental. Deste modo, como o cético, na exposição de Montaigne, é quem está sempre em dúvida, ele se define por buscar um estado de constante oscilação do espírito, de modo a estar sempre perplexo e indeciso. Embora não se possa considerar que esta seja uma descrição favorável do ceticismo, Montaigne faz uma apologia do ceticismo, mas o faz pela tentativa de legitimar a noção de dúvida:

E por essa extremidade da dúvida que se balança a si mesma, os pirrônicos dividem-se e se separam em várias opiniões, inclusive devido às que mantêm de diversas formas a respeito da dúvida e da ignorância. Por que isto não lhes seria permitido, perguntam, quando entre os dogmáticos um possa dizer verde e o outro amarelo, a eles também duvidar? Poderá alguém propor-nos que aceitemos ou neguemos qualquer coisa, sem que nos seja lícito a considerar como ambígua? (1979, p. 237: II, 12, 503) 
Em face das infinitas controvérsias entre os filósofos dogmáticos, por que não seria lícito decidir-se pelo caminho da dúvida? Portanto, para Montaigne, o cético é quem escolhe o caminho da dúvida como a sua alternativa filosófica. O ceticismo, ou uma "filosofia da dúvida", se torna equivalente a uma alternativa legítima para o pensamento, e inclusive talvez seja a mais sábia e moderada: "Um espírito isento de preconceitos é uma vantagem preciosa para a nossa tranquilidade. Quem julga e controla seus juízos não se submete jamais convictamente." (1979, p. 238).

Portanto, por um lado, "sustento, não me movo" significa: estou livre para não seguir, e não sigo a onda de inconstância e de contínua irresolução das opiniões e, sobretudo, das mudanças de opinião. Portanto, pode-se entender que "je soutiens, je ne bouge" significa que sustento a minha posição, não mudo de opinião, não me movo de onde já estou, de modo que permaneço firme, estável, e alheio à instabilidade do movimento.

Por outro lado, "sustento, não me movo" da minha posição justamente ao esposar a dúvida e indecisão. Se o ceticismo pode manter-me fixo onde estou, contudo, não produz um estado de equilíbrio. Através do exercício da dúvida, sou capaz de "ficar de fora da confusão", sustentando minha posição; porém, o modo de sustentá-la é fazer o espírito lançar-se em um estado de constante hesitação e perplexidade. O cético, não entanto, não sustenta nenhuma crença ou teoria; ao passo que a Apologia é uma defesa da religião católica - sem esta posição original para se "sustentar" e dar "continuidade", a exposição do ceticismo na Apologia perderia o fundamento que a sustenta.

Conhecendo a instabilidade do meu julgamento, reagi e, excepcionalmente, cheguei a certa continuidade de opinião, conservando mais ou menos intactas as que a princípio tivera. Pois, qualquer que seja a aparência de novidade, não mudo de medo de perder na troca. Incapaz de escolher por mim mesmo, confio na escolha de outrem e atenho-me às condições em que Deus me colocou sem o que não poderia impedir-me de variar amiúde. Assim é que, com a graça de Deus, conservei inteiras, sem inquietações nem casos de consciência, as antigas crenças 
de nossa religião, a despeito de tantas seitas e divisões observadas em nosso século (1979, p.267; II, 12, 569).

Se, para o cético, não há a necessidade de conservar uma crença, de modo que não faria sentido o medo de mudar e de "perder na troca", por que o cético duvidaria, e buscaria estar sempre perplexo? Qual seria a sua motivação? Isto não parece ficar claro na Apologia. Sem a "graça de Deus", mas, considerado em si mesmo, o ceticismo aparenta ser apenas um exercício de futilidade, sendo o cético um indivíduo perturbado e desorientado, que, talvez por não saber o que buscar, busca estar sempre em dúvida e num estado de constante perplexidade e indecisão.

Após Montaigne, nas referências ao ceticismo, nota-se a sua completa identificação com a dúvida. Apesar de Descartes não mencionar os céticos em nenhum lugar nas Meditações (1641), nas Resposta a Objeções escreve que teria "derrubado a dúvida dos céticos": ao fazer a dúvida derrubar a si mesma, ela levaria o ceticismo consigo. Mas, já em 1625, Marin Mersenne no diálogo La vérité des sciences contre les sceptiques ou pyrrhoniens, levanta uma objeção similar: se sabes que estás em dúvida, não duvidas de tudo; logo, "seria preciso dizer um eterno adeus ao seu Pirronismo" (Livro I, p. 204).

Na medida em que a dúvida é tomada como a característica principal do ceticismo, as críticas que se voltam contra o cético e almejam refutá-lo são direcionadas, na verdade, ao próprio conceito de dúvida. Ao ser reconcebido através da dúvida e tornar-se equivalente a ela, os diferentes modos de lidar com o ceticismo no período moderno (as tentativas de refutá-lo, de absorvê-lo ou de superá-lo) direcionam-se para esta releitura do ceticismo. Deste modo, refutar a pretensão de "estar sempre em dúvida" e de "duvidar de tudo" é visto como uma refutação do próprio ceticismo. A dúvida, ausente no ceticismo grego, torna-se a característica principal do ceticismo, e este se torna o seu legítimo proprietário e representante. 


\section{7}

\section{Conclusão}

Iniciamos pelo exame da extensão em que atualmente está difundida a sinonímia entre dúvida e ceticismo, e a contrapartida do impactante fato histórico de que Sexto Empírico, a principal fonte textual da filosofia cética antiga, não se referir a este concentio em sua descrição do cético pirrônico. Os principais especialistas em ceticismo que tentam explicar esta desconcertante anomalia buscam, de alguma forma, aproximar conceitualmente dúvida e ceticismo. Isto, no entanto, nos parece ser um equívoco: embora seja possível - como atesta a própria história - pensar o ceticismo através da dúvida, a significância do pirronismo nos parece ser inteiramente outra, e até mesmo ser estranha, alheia ao ato de duvidar ou de "lançar dúvidas" sobre doutrinas e, mais distante ainda, do fenômeno mental de estar em dúvida e da atitude de duvidar do conhecimento ou da capacidade humana de conhecer. Em toda a sua polissemia, a dúvida parece-nos ficar ao largo do que na Antiguidade possa ter significado ser um cético pirrônico.

Este nos parece ser o caso principalmente ao analisar a atitude cética e o estado mental ocasionado pela prática do ceticismo. Caracterizado por Sexto empírico como a capacidade de oposição, que leva à prática e ao estado suspensivo de não asserção, o ceticismo evita dogmatizar, não conferindo o seu assentimento nem a afirmação, nem á negação a algo não evidente. Com isso, delineia-se um estado mental de equilíbrio, "não mais isso ou aquilo" parece ser o que caracteriza esse estado, bem como a tranquilidade e a paz de espírito. Evitando-se dogmatizar e mantendo afiada a prática de evitar o dogmatismo, o cético seria capaz de viver bem seguindo apenas aquilo que aparece; o "critério cético" de viver de acordo com o que se sabe não dogmaticamente. 
De acordo com esta compreensão do pirronismo - obviamente incompleto e passível de diversas críticas e objeções - parece-nos que se deve levar a sério o que Sexto afirma nas linhas de abertura das Hipotiposes: o ceticismo é um dentre os três tipos de filosofia, assim como um dentre os três resultados naturais de toda investigação. Pode-se entender o tipo cético de filosofia ou de resultado para uma investigação não apenas como a ausência de resultado e a permanênia na busca, mas também como um resultado definido: ser cético, ou estar cético, assinala um fenômeno mental específico, distinto tanto da crença (dogmatismo) e da descrença (dogmatismo negativo), quanto da dúvida, que consiste em estar entre a crença e a descrença. Dessa maneira, o ceticismo seria capaz de expressar um fenômeno ou estado da consciência, que não é o de estar entre alternativas, mas de estar para além delas. Tal fenômeno ocorre após examinar as alternativas, suspender-se delas, e possivelmente até esquecê-las, sem, contudo, haver decidido nada, e tampouco desconsiderar a questão como menor ou indigna de atenção. Apenas, não sentir-se capaz de decidir a questão, e de fato não decidir, mas de toda forma examiná-la detidamente e terminar o exame, não indeciso, mas com a impressão de ser indecidível. Talvez, este estado ou fenômeno mental não seja comum, mas nos parece ser um fenômeno específico da consciência, distinto da dúvida, crença e da descrença. Para que se tenha uma impressão mais vívida deste fenômeno, basta lembrar-se da primeira leitura das Antinomias da Razão Pura, ou do primeiro contato com os paradoxos de Zenão - termina-se com a impressão de serem indecidíveis, mas não se pode crer nem descrer, duvidar ou julgar acerca de nada. "P" e " p p" dissolvem-se, de ambos "suspende-se". Desta forma, pode-se imaginar que com o desenvolvimento da neurociência e das técnicas de imageamento do funcionamento do cérebrotalvez seja possível no futuro, além de se conseguir mapear a atividade cerebral nos estados de crença, descrença, dúvida e incredulidade, também o fenômeno mental cético de estar "em suspenso".

Com esta compreensão da significância do ceticismo, entendemos que dúvida e ceticismo não possuem nenhuma relação direta ou imediata, mas são independentes entre si, até mesmo contraditórias em suas motivações e atitudes básicas. Em vez de duvidar e oscilar entre alternativas, o cético se suspende das 
alternativas e, renunciando ao impulso de julgar, fica "em suspenso", num estado mental de equilíbrio, indiferença e tranquilidade. Logo, o cético não duvida, não tem origem na dúvida nem é uma solução ou resposta a ela, e tampouco é dúvida a sua tarefa ou o seu objetivo.

Como a dúvida é um fenômeno ou estado mental, que pode acometer a todos, especialmente a todo filósofo, pode-se afirmar que "duvidar" não caracteriza por si só a especificidade de nenhuma forma de pensamento ou filosofia. A dúvida nem é característica ou exclusiva ao ceticismo - pois o pensador dogmático também duvida - nem há nada de especificamente cético na dúvida. E se "duvidar" realmente pudesse expressar um tipo de filosofia, vimos que, ao contrário de ser equivalente ao ceticismo, a dúvida parece estar filiada ao dogmatismo de um modo essencial. "Duvidar", ou "estar em dúvida" diz respeito a um estado mental em que a decisão está adiada por algum obstáculo, logo, a consciência oscila, vacila, hesita para escolher. Portanto, o que está na base da atitude de duvidar é a dificuldade em tomar uma decisão, em formular um juízo, ou tomar algo como verdadeiro. E nota-se que isto é precisamente o que o cético pirrônico não faz. $\mathrm{O}$ cético pirrônico é um pensador cuja prática filosófica consiste em viver bem, renunciando à tentativa de chegar a uma decisão sobre a verdade e, mais especificamente, de julgar sobre aquilo que é não evidente. $O$ cético renuncia à vontade ou impulso de julgar, sem o qual não se caracteriza um estado de dúvida. Não sendo o seu ofício a formulação de crenças ou juízos, mas o ofício do filósofo dogmático pode-se pensar que duvidar é um estado mental que ocorre mais frequentemente num modo dogmático do que cético de filosofar. A dúvida enquanto atitude e estado mental contém um maior potencial de interesse para o filósofo dogmático do que para o cético. Como a experiência da dúvida representa um obstáculo em sua busca da verdade, poderia vir a ser considerada digna da sua atenção e análise.

De acordo com nossa compreensão do ceticismo, buscamos entender o processo de introdução da dúvida na filosofia cética de modo radical, ou seja, como a introdução de um novo termo e uma nova noção em textos e em uma 
forma de pensamento em que a dúvida não tinha lugar, em que estava inteiramente ausente. E este parece ser o caso, inclusive da filsoofia grega clássica, em que não se vê nenhum uso filosófico da noção de dúvida. No entanto, deve-se notar que, tanto quanto é um fato textual que não há dúvida no ceticismo pirrônico, é um fato histórico que seja possível pensar o ceticismo através do conceito de dúvida - e assim é pensado desde a sua retomada no início do século XV. Contudo, se dúvida e ceticismo assinalam atitudes e estados mentais opostos e contraditórios, como foi e como é possível pensá-lo desta maneira?

Ao se avaliar a conexão entre ceticismo e dúvida, por um lado, pode-se pensar ser um nominalismo excessivo afirmar que não há dúvida no ceticismo, pois, mesmo que não haja um termo correspondente à dúvida no texto de Sexto Empírico, nele se poderia identificar a dúvida enquanto atitude. Mas, por outro lado, encontra-se a armadilha do uso catacrético do termo dúvida, que é o caso, por exemplo, quando se diz que a dúvida pertenceria a toda filosofia enquanto parte da "atitude crítica". Pode-se notar que, ao se introduzir a dúvida no ceticismo (e na filosofia em geral), frequentemente opera-se com uma noção filosoficamente elaborada de dúvida. Quando o pensamento filosófico apropria-se de um termo da linguagem comum, costuma ocorrer que, nesta conceitualização, o seu campo semântico seja ampliado para muito além do seu uso comum. Desta forma, ao ser apropriado pela filosofia, confere-se um sentido filosófico ao conceito de dúvida, o que se pode fazer de muitas maneiras, sendo o significado e o valor da dúvida dependentes do modo como é elaborado filosoficamente o seu conceito. Consequentemente, a partir de qual seja a sua elaboração filosófica, o conceito de dúvida pode ser introduzido no ceticismo também de diversas maneiras.

Portanto, a polissemia da noção de dúvida é uma primeira questão que torna problemática a introdução da dúvida no ceticismo: quando se afirma que o cético duvida, de que modo se entende a dúvida? Em seu sentido próprio, tal como o termo é utilizado na linguagem comum, a dúvida assinala um determinado estado mental: um estado da consciência caracterizado pela oscilação e hesitação entre 
duas ou mais alternativas. Mas, ao se pensar na dúvida em outros sentidos, seja como índice de liberdade, ou como parte da atitude crítica, seja como oposta à certeza e critério negativo para a epistemologia, atribui-se novos significados ao termo, que estão ausentes em seu sentido comum ou original. Em seu sentido próprio, enquanto estado de oscilação, hesitação e indecisão do espírito, a dúvida é contraditória com o ceticismo e, deste modo, a simples equivalência entre ser cético e duvidar, uma vez que se torna explícita, mostra-se ser demasiadamente caricatural. Isto se pode notar nas descrições de Montaigne (e Descartes) do cético como alguém que duvida por ofício, sendo a sua tarefa buscar permanecer em um constante estado de dúvida, indecisão e perplexidade, mesmo se não houver razões suficientes para duvidar. Nesta descrição, o cético torna-se um indivíduo que está ininterruptamente em dúvida - um indivíduo impossível, uma personagem absurda. Por conseguinte, faz-se necessário transferir as incoerências da leitura do cético como um indivíduo que sempre duvida para o próprio ceticismo, e pensar o "cético" ou como um indivíduo desonesto, que apenas finge ser cético e de tudo duvidar, ou como um indivíduo atormentado, psicologicamente desequilibrado, sempre indeciso e vacilante.

Deste modo, pode-se afirmar que é devido aos usos catacréticos e filosóficos da noção de dúvida que se torna possível inseri-la em todas as etapas do procedimento cético, e mesmo reinterpretar todo o ceticismo através desta única noção, como vimos ocorrer na Apologia, de Montaigne. Por outro lado, pode-se dizer que algo similar ocorre em relação ao próprio conceito de dúvida. Ao ser apropriado pelo pensamento filosófico, bem como ao ser pensado como equivalente ao ceticismo, corre-se o risco de se descaracterizar o próprio conceito de dúvida, de modo a tornar turvo seu significado próprio. Como vimos, isto é o que ocorre na definição de dúvida efetuado por Corti que, buscando distinguir entre dúvida e ceticismo, em vez disso torna a dúvida indistinguível da suspensão. Outro exemplo é a dúvida cartesiana, que é metafísica, hiperbólica, ligeira, voluntária, e artificial, etc. Após o acréscimo de todos estes novos predicados, em que medida esta "dúvida metafísica" é propriamente "dúvida"? Segundo alguns, a resposta seria "nenhum”: a dúvida cartesiana não é uma dúvida natural (M. 
Williams); não é uma dúvida real (C. S. Pierce). Portanto, ao se identificar ceticismo e dúvida, no entanto, corre-se o risco de turvar a compreensão tanto do ceticismo pirrônico, quanto do fenômeno mental da dúvida. É perfeitamente possível descrever o ceticismo independentemente da noção de dúvida - tal como faz Sexto Empírico, mas o contrário não procede: não se pode descrever o ceticismo pirrônico com precisão através do conceito de dúvida; ao se interpretálo como equivalente a uma doutrina da dúvida, perde-se o seu significado próprio.

Dúvida e ceticismo são independentes entre si, tanto histórica quanto conceitualmente. Historicamente, ceticismo e dúvida tornam-se equivalentes, no entanto, tanto antes quanto depois deste fenômeno histórico e cultural, pode-se afirmar que a noção de dúvida e o ceticismo permanecem em seus caminhos históricos próprios e independentes entre si. Pode-se oferecer como exemplo o uso jurídico do conceito de dúvida razoável ${ }^{101}$ (in dubio pro reo). Embora o direito moderno possa ter sofrido influências do pensamento cético, não se pode encontrar nenhuma menção ao ceticismo propriamente na doutrina jurídica da dúvida razoável, mas apenas uma apropriação específica da própria noção de dúvida. Como vimos, a dúvida é inserida no ceticismo desde a sua retomada no contexto do humanismo rensacentista. Contudo, pode-se pensar que a noção de dúvida possua uma trajetória própria na história das ideias. Inicialmente um termo da linguagem comum, a dúvida é elaborada filosoficamente de múltiplas maneiras, tornando-se relevante para o pensamento filosófico através de diversos caminhos, tanto em conexão com a influência de Cícero (na retórica, oratória, a liberdade para pensar acadêmica) - sendo Cícero talvez um dos primerios a apropriar-se filosóficamente do conceito, quanto independentemente da sua obra, como por exemplo, em conexão com questões epistemológicas oriundas do próprio contexto da filosofia natural escolástica, sem relação com fontes céticas antigas. Não haveria, portanto, entre a filosofia cética antiga e o fenômeno histórico de introdução e transformação do ceticismo através da dúvida no renascimento uma relação de continuidade, e sim de ruptura.

101 Cf. WALDMAN, T. (1959). 
O que pode indicar a relação de descontinuidade da tradição cética antiga e a nova tradição cética que se forma na modernidade é a própria trajetória independente da noção de dúvida, que então é inserida nas traduções e nas releituras das fontes céticas antigas. A ambiguidade da dúvida produzida através das suas elaborações filosóficas é representativa deste processo e fenômeno culturais. Por um lado, como vimos em Salutati, Buridan, Lutero, e Gianfrancesco Pico della Mirandola, é uma constante a conotação negativa da dúvida, que pode ser considerada comum à noção, na medidade em que se caracteriza como um estado de hesitação, oscilação, indecisão, ansiedade: a dúvida opõe-se à certeza, representando um obstáculo rumo à verdade. Mas, por outro lado, torna-se cada vez mais frequente uma conotação positiva da dúvida, visível em João de Sailsbury, Jean Gerson, Lorenzo Valla, e Omer Talon, e que tem em Cícero a sua inspiração mais evidente. De acordo com este entendimento, a dúvida opõe-se ao dogma, representando uma atitude de abertura à verdade.

Com a inserção da dúvida no ceticismo e sua transformação através desta noção, o que ocorre a partir da redescoberta das fontes céticas no Renascimento, os modos mais comuns de se entender o ceticismo correspondem a esta ambiguidade da dúvida, como vimos em relação aos "dois ceticismos" descritos por Olaso: a ambiguidade da dúvida, já pertencente ao seu conceito previamente à redescoberta do ceticismo, é transposta ao entendimento do ceticismo, tornando-se também o ceticismo envolto em uma ambiguidade fundamental: por um lado, “[...] o cético é um homem que professa uma constante dúvida a respeito de tudo; [por outro lado], é um homem capaz de colocar em dúvida as suas próprias opiniões" (Olaso, 1975, p. 28). Nesta ambiguidade dos modos mais frequentes de se pensar o ceticismo no Renascimento, não se pode encontrar o seu significado antigo ou pirrônico: pois o cético nem professa a dúvida, nem coloca em dúvida suas próprias opiniões. Este último sentido é claramente derivado de uma inspiração ciceroniana, pois este é o sentido que atribui aos "acadêmicos". Podese considerar que o "primeiro ceticismo", no entanto, possui uma história mais complexa, ao mesmo tempo em que está mais próximo do significado comum da dúvida, e sua apropriação filosófica não possui inspiração clara em um único 
autor. Após o período renascentista, esta ambiguidade de dúvida torna-se ainda mais ampla e clara.

Com Descartes, a ambiguidade da dúvida espraia-se não apenas para o significado do ceticismo, mas é introduzida na reconcepção da própria filosofia: insere-se a dúvida no início do filosofar, como etapa inicial da investigação fillosófica ("A filosofia começa pela dúvida", "É preciso duvidar de tudo"), bem como no fim do filosofar, o qual passa a consistir em alcançar o indubitável. Neste sentido, a dúvida é um obstáculo a ser ultrapassado; uma etapa preliminar cuja superação sedimenta os alicerces do conhecimento certo e seguro, e, ao mesmo tempo, cristaliza-se na atitude que leva a esta conquista e a representa: a dúvida é um método de descoberta da verdade. Deste modo, a dúvida opõe-se ao dogma, representando a "atitude crítica" da investigação filosófica, mas, ao mesmo tempo, enquanto "método" ou "princípio" representa o caminho rumo à verdade. A dúvida possui a um passo um sentido positivo e negativo, sendo ambíguo, a todo instante, o seu significado e o seu valor - e, a reboque, a significância e sentido do ceticismo. Em meio à polissemia e à ambiguidade da dúvida, marcantes no Renascimento e na filosofia moderna, mas cujas raízes são anteriores ao próprio início do período moderno, que se situa a retomada do ceticismo, sendo tragado, apropriado e transformado pelo novo contexto em que se situa. Nessa medida, não há, entre ceticismo antigo e moderno, a continuidade de uma "tradição": o novo ceticismo, em que a dúvida desempenha função central, é uma invenção moderna, sem precedentes na Antiguidade - sendo a própria expressão "dúvida filosófica" uma invenção característica da modernidade.

Por fim, cabe ressaltar que, como é de costume, o processo histórico não irá se reverter, mas não é bem disso que se trata; o que buscamos chamar a atenção não é para o uso correto de nomes e conceitos, mas para fenômenos: o ceticismo pirrônico possui uma identidade própria independentemente da dúvida, sendo mais vantajoso tentar investigá-la em si mesma e refletir sobre o que se pode encontrar. 
8

Referências Bibliográficas

\section{BIBLIOGRAFIA PRIMÁRIA}

ARISTOTELES. Works, 2 vols. [The Great Books] Chicago, London, Toronto: The University of Chicago Press, 1952.

BAYLE, P. Historical and Critical Dictionary. Selections. Ed. Richard Popkin. Indianapolis: Jackett Publishing Company, 1991.

CÍCERO. De Natura Deorum et Academica. Michigan: Harvard University Press, 2005. . De officiis. London: William Heineman Ltd., 1928. Tusculan Disputations. Boston: Little, Brown and Company, 1886. De Oratore. London: William Heineman Ltd., 1942.

DANTE ALIGHIERI. Il Convivio. Eds. Busnelli \& Vandelli. Firenze, Felice Le Monnier 1964 (Opere di Dante, vol. V. 1a EDIZIONE ELETTRONICA DEL: 22 dicembre, 1998). Disponível em:

http://www.liberliber.it/mediateca/libri/a/alighieri/convivio_edizione_busnelli_van delli/pdf/conviv_p.pdf Acesso em: 22/05/14

The Convivio of Dante Aleghieri. Editor Paul W. Wicksteed. Edinburgh, 1824. Disponível em:

https://archive.org/stream/convivioofdantea00dantiala\#page/446/mode/2up. Acesso em: 23/05/2014.

DESCARTES, R. Discours de la Méthode. Texto e Comentário: Étienne Gilson. Paris: J. Vrin, 1947.

Discurso do Método. Tradução: Maria Ermantina Galvão. São Paulo: Martins Fontes, 2003.

Meditações sobre a Filosofia Primeira. Tradução: Prof. Gustavo de Fraga. Coimbra: Livraria Almedina, 1988.

Philosophical Writings (2 vols.) Tradução: Haldane \& Ross. London \& New York: Cambridge University Press, 1967.

Principios da Filosofia. Tradução João Gama. Lisboa: Edições 70.

Oeuvres (vol. IX - 1: Meditations; Traduction Française) Edição: Adam \& Tannery. Paris: J. Vrin, 1964. 
DIOGENES LAÉRCIO The Lives and Opinions of Eminent Philosophers. Trad. C. D. Yonge. London: George Bell and Sons, 1901.

ERASMO DE ROTERDAM. Elogio da Loucura. Rio de Janeiro: Edições de Ouro. . De Libro Arbitrio. In: Luther and Erasmus: Free Will and Salvation. RUPP \& WATSON (Eds.) Philadelphia: The Westminster Press, 1969.

HENRY of GHENT. (2008) Henry of Ghent's Summa of Ordinary Questions: Article One: On the Possibility of Knowing. Chicago: St. Augustine's Press.

KANT, I. Lógica. Rio de janeiro: Tempo Brasileiro, 2011. . Notes and Reflections. Cambridge: Cambridge Uniersity Press, 2005.

MARTINHO LUTERO De Servo Arbitrio. In: Luther and Erasmus: Free Will and Salvation. RUPP \& WATSON (Eds.) Philadelphia: The Westminster Press, 1969.

MATES, B. (1996) The Skeptic Way: Sextus Empiricus's Outlines of Pyrrhonism. New York: Oxford University Press.

MELANCHTHON. P. (2008) Loci Communes Theologici. In: PAUCK, W. (Ed.) Melanchthon and Bucer. Louisville: Westminster John Knox Publishers.

MERSENNE, M. (1625) La vérité des sciences contre les sceptiques ou pyrrhonien. Paris: Touissanct du Bray.

MONTAIGNE, M. de Essais, V.-L. Saulnier e P. VIlley (eds.), Paris: PUF. . (1979) Ensaios. Col. Os Pensadores. São Paulo: Abril Cultural. . (2006) Os Ensaios, Livro II. São Paulo: Martins Fontes.

NAUDÉ, G. (1950) On Establishing a Library. Berkeley and Los Angeles: University of California Press.

NETTESHEIM, H.C.A. de. (2010) Sur L'Incertitude, Aussi Bien Que La Vanite Des Sciences Et Des Arts (1726). Kessinger Publishing.

FRANCESCO PETRARCA. Traité de sui ipsius et multora ignorantiam. Par L. M Capelii, 1906, Paris.

PLATÃO. Mênon. São Paulo: Edições Loyola, 2001.

Works. [The Great Books] Chicago, London, Toronto: The University of Chicago Press, 1952.

SALISBURY, John of. (1972) Policraticus. Ed. Joseph B. Pike. New York: Octagaon Books.

SANCHES, F. Que nada se sabe. In: SANCHES, F. Tratados Filosóficos, vol. I. Lisbora, ed. IAC, 1955.

SANTO AGOSTINHO Against the Academics. NY: The Newman Press, 1951.

Confissões e De Magistro (Do Mestre). [Col. Os Pensadores] São Paulo, Abril Cultural, 1980.

. De Sancta Virginitate, liber unus. Salisburgi, 1845. 
On the Trinity, Books 8-15. Ed. G. Matthews. Cambridge: Cambridge University Press, 2002.

SEXTO EMPÍRICO. (1993) Esbozos Pirrónicos. A. G. Cao \& T. M. Diego (eds.) Madrid: Editorial Gredos. . (1996) Hipotiposis Pirrónicas. R. S. Maulini (ed.) Madrid: Ediciones Akal. du Seuil (1997) Esquisses Pyrrhoniennes. Tradução Pierre Pellegrin. Paris: Éditions (2000) Outlines of Scepticism. Julia Annas \& J. Barnes (eds.) Cambridge: Cambridge University Press.

. (1933-49) Works, 4 vols. Tradução R. G. Bury. Cambridge: Harvard University Press.

STEPHANI, H.; HERVET, G. Sexti Empirici Opera Graece et Latini. Leipzig: Sumptu Librariae Kuehnianae, 1841.

TRAVERSARI, A. Diogenis Laertii De vita et moribus philosophorum libri IX. Lugduni, 1566.

VAYER, L. M. L. (2011) “Sobre Pirro e a seita cética” (tradução Plínio Junqueira Smith). In: Sképsis, Ano IV, n.7, pp.151-67.

\section{BIBLIOGRAFIA SECUNDÁRIA}

ALLEN, D. C. (1964) Doubt's Endless Sea. Baltimore: Johns Hopkins Press.

ANNAS, J. \& BARNES, J. (1985) The Modes of Skepticism. New York: Cambridge University Press.

ARENDS, J. F. M. (2008) "From Homer to Hobbes and Beyond - Aspects of 'Security' in the European Tradition" In: P. H. LIOTTA et al (eds.) Globalization and Environmental Challenges: Reconceptualizing Security in the $21^{\text {st }}$ century. Berlin; Heidelberg; New York: Springer, pp.263- 278.

ARENDT, H. (2008) A Condição Humana. Rio de Janeiro: Forense Universitária.

ASP, E. / MANZEL, K. / KOESTNER, B. / COLE, C. A. / DENBURG, N. L. / TRANEL, D. "A neuropsychological test of belief and doubt: damage to ventromedial prefrontal cortex increases credulity for misleading advertising" in: Frontiers in Neuroscience, vol.6, art. 100, pp. 1-9.

BACKUS, I. "The issue of Reformation skepticism revisited: what Erasmus and Sebastian Castellio did or did not know" in: PAGANINI \& MAIA NETO (eds.) Renaissance Scepticisms. Dordrecht: Springer, pp. 61-90. 
BARNES, J. (1984) The significance of Philosophical Scepticism. Oxford: Oxford University Press

BERMUDEZ, J. L. (2000) "The originality of cartesian Scepticism: did it have ancient or medieval antecedents?” in: History of Philosophy Quarterly, pp. 333-360.

BICCA, L. (2014) “A Atitude de Pirro”. In: Revista Prometeus, Ano 7, $n^{\circ}$ 16, JulhoDezembro, pp. 1-22.

. (2009) “Carnéades em Roma: ceticismo e dialética” In: skepsis, ano iv, nº 5, pp. $77-101$.

(2012) Ceticismo e Relativismo. Rio de Janeiro: 7 Letras.

. (2009) "Hegel: o ceticismo na dialética". In: o que nos faz pensar?, $n^{\circ} 25$.

(1997) Racionalidade moderna e subjetividade. São Paulo: Edições Loyola.

BOLZANI, R. (1998) “Acadêmicos versus Pirrônicos”. In: Discurso (29), pp. 57-110.

_. (1996) “A Epokhé cética e seus pressupostos”. In: Discurso (27), pp. 36-70.

(1990) "Ceticismo e Empirismo". In: Discurso (18), pp.37-67.

BRAHAMI, F. (2012) "Das Hipotiposes aos Ensaios. O que está em jogo em uma ruptura”. In: Skepsis, ano V, nº 8, pp. 66-77.

. (2013) “Montaigne e a política.” In: Skepsis, ano VI, $n^{o}$ 9, pp. 86-114.

. (2002) "Dubito ergo sum: Descartes et le cogito des cartésiens". In: A. McKENNA (ed.) La Lettre Clandestine, n.10 - 2001.

BROCHARD, V. (2009) Os céticos gregos. São Paulo: Odysseus.

BROUGHTON, J. (2002) Descartes's method of doubt. New Jersey: Princeton University Press.

BURNYEAT, M. (1980) "Can the Sceptic Live His Scepticism?” in: M. SCHOFIELD, M. BURNYEAT \& J. BARNES (eds.) Doubt and Dogmatism. Oxford: Oxford Clarendon Press, pp. 20-53.

. (1982) "Idealism and Greek Philosophy: What Descartes saw and Berkeley missed” In: The Philosophical Review, XCI, No. 1 (January 1982), pp. 3-40.

. (1998) "The Sceptic in his Place and Time". In: M. BURNYEAT \& M. FREDE (eds.) The Original Sceptics: A Controversy. Indianapolis: Hackett.

CAO, G. M. (2009) "Inter Alias Philosophorum Gentium Sectas, et Humani, et Mites: Gianfrancesco Pico and the Sceptics.” In: Paganini, G. / Maia Neto, J. R. (eds.) Renaissance Scepticisms. Dordrecht: Springer, pp.127-147.

. (2001) "The Prehistory of Modern Scepticism: Sextus Empiricus in FifteenthCentury Italy" in: Journal of the Warburg and Courtauld Institutes, Vol. 64, pp. 229-280. 
CASSIRER, E. (1972) An Essay on Man. New Haven and London: Yale University Press.

. (2001) Indivíduo e Cosmos no Renascimento. São Paulo: Martins Fontes.

. (1965) El problema del conocimiento en filosofia y en la ciencia. Mexico, Buenos Aires: Fondo de Cultura Economica.

CLARKE, T. (1972) “The Legacy of Scepticism” in: The Journal of Philosophy, Vol. 69, No. 20, pp. 754-769.

COLISH, M. L. (1998) Medieval Foundations of the Western Intellectual Tradition, 4001400. Wiltshire: Yale University Press.

COPENHAVER, B. P. \& SCHMITT, C. (1992) Renaissance Philosophy. Oxford \& New York: Oxford University Press.

CORTI, L. (2012) “Sexto Empírico: Ceticismo sem dúvida”. In: W.J.S. FILHO \& P.J. SMITH (Eds.) As Consequencias do Ceticismo. São Paulo: Alameda, pp.45-61.

COUISSIN, P. (1983) “The Stoicism of the New Academy” In: M. BURNYEAT (ed.) The Skeptical Tradition. Berkeley and Los Angeles: University of California Press, pp.31-64.

. (1927) "L'Origine et l'Evolution de l'Epoche" in: Revue des Etude Grecques, n. 42 , pp. 373-397.

ERNST, G. (2010) Tommaso Campanella: the Book and the Body of Nature. New York: Springer.

FINE, G. "Descartes and Ancient Skepticism: Reheated Cabbage?" in: The Philosophical Review, vol. 109, No.2, pp.195-234.

FLORIDI, L. (2002) Sextus Empiricus: the transmission and recovery of Pyrrhonism. New York: Oxford University Press. .(1995) "The Diffusion of Sextus Empiricus's Works in the Renaissance" in:

Journal of the History of Ideas, Vol. 56, No. 1, pp. 63-85. . The Grafted branches of the sceptical tree.

. (2010) “The Rediscovery and posthumous influence of scepticism". In: R. BETT (ed.) The Cambridge Companion to Ancient Scepticism. Cambridge: CUP, pp.267-287.

FRANKFURT, H. G. (2008) Demons, Dreamers and Madmen. Princeton: Princeton University Press.

FREDE. M. (1998) “The Sceptics Two Kinds of Assent”. In: M. BURNYEAT \& M. FREDE (eds.) The Original Sceptics: A Controversy. Indianapolis: Hackett.

GARBER, D. "Semel in Vita: The Scientific Backgroud to Descartes' Meditations" In: RORTY, A. O. (ed.) Essays on Descartes' Meditations. Berkeley: University of California Press, pp.81-116.

GILSON, E. (2001) A Filosofia na Idade Média. São Paulo: Martins Fontes. 
. (1955) History of Christian Philosophy in the middle Ages. London: Sheed and Ward.

GIOCANTI, S. (2004) "Classicisme philosophique et marginalité: scepticisme et libertinage" in: Dix-septième siècle, vol. 3, n 224, pp. 369-380.

. (2002) "Descartes face au doute scandaleux des sceptiques" In: Dix-septième siècle, vol. $4, \mathrm{n}^{\circ} 217$, p. 663-673.

GLUCKER, J. (1996) “Cicero's philosophical affiliations”. In: DILLON, J. M. \& LONG, A. A. (Eds.) The Question of "eclecticism": Studies in Later Greek Philosophy. Berkeley: University of California Press, pp. 34-69.

GRANT, E. (2008) The Foundations of Modern Science in the Middle Ages. New York: Cambridge University Press.

GRENE, M. (1999) "Descartes and Skepticism," in: Review of Metaphysics, n. 52, pp. 553-571.

HADOT, P. (1999) O que é a filosofia antiga? São Paulo: Loyola.

HANKINSON, R.J. (2010) "Aenesidemus and the rebirth of Pyrrhonism" In: R. BETT (ed.) The Cambridge Companion to Ancient Scepticism. Cambridge: CUP, pp. 105119.

(1995) The Sceptics. NY: Routledge.

HARRIS, S. / SHETH, S. A. / COHEN, M. S. "Functional Neuroimaging of Belief, Disbelief and Uncertainty" in: American Neurological Association, n. 63, pp. 141147.

HEGEL, G.W.F. (2006) Lectures on the History of Philosophy. Volume II: Ancient Philosophy. Oxford: Oxford University Press.

HUNT, T. J. (1998) A Textual History of Cicero's Academici Libri. Leiden, Boston, Köln: Brill.

KAHN, C. H. (1996.) Plato and the Socratic Dialogue: The Philosophical Use of a Literary Form. Cambridge: Cambridge University Press.

KIERKEGAARD, S. (2003) É preciso duvidar de tudo. São Paulo: Martins Fontes.

KOYRÉ, A. (1944) Entretiens sur Descartes. New York: Brentano’s.

(1979) From the Closed World to the Infinite Universe. Baltimore: Johns Hopkins University Press.

LANGER, S. K. (1929) "The Treadmill of Systematic Doubt" In: The Journal of Philosophy, Vol. 26, No. 14, pp.379-84.

LAURSEN, J. C. (2010) “The Archeology of Skepticism”. In: Iris, II, 3, pp. 197-203.

LENNON, T. (2008) The Plain Truth. Leiden: Brill. 
LONG, A. A. (2006) "Aristotle and the history of Greek skepticism” In: LONG, A. A. (2006) From Epicurus to Epictetus. Studies in Hellenistic and Roman Philosophy. NY: Oxford University Press, pp. 43-69.

LONG, A. A. \& SEDLEY, D. N. (1987) The Hellenistic philosophers, 2 vols. Cambridge: The Press Syndicate of the University of Cambridge.

MAIA NETO, J. R. (2003) (1997) "Academic Skepticism in Early Modern Philosophy". In: Journal of the History of Ideas, Vol. 58, No. 2 pp. 199-220.

. (2003) "Charron's epoche and Descartes' Cogito: the sceptical base of Descartes refutation of Skpeticism". In: PAGANINI (ed.) The Return of Scepticism. From Hobbes and Descartes to Bayle. Dordrecht: Kluwer Academic Publishers.

(1994) "De Montaigne a Pascal: do fideísmo cético à cristianização do ceticismo": págs 66 - 71. In: $O$ que nos faz pensar?, $\mathrm{N}^{\circ}$ 8: Edição sobre Ceticismo.

. (2012) "O contexto religioso-político da contraposição entre Pirronismo e Academia na 'Apologia de Raymond Sebond"'. In: Kriterion, n' 126, pp. 351-374.

MARCONDES, D. (s/d) "A Tradição Cética".

. (2007) "Juízo, suspensão do juízo e filosofia cética". in: Skepsis, ano i, nº 1, pp.69-82

. (1993) "Há ceticismo no pensamento medieval?" in: L. A. de BONI (org.) Lógica e Linguagem na Filosofia Medieval. Porto Alegre: EDIPUCRS, pp. 283294.

. (20xx) Iniciação à História da Filosofia. Rio de Janeiro: Jorge Zahar.

. (2012) "Montaigne, a Descoberta do Novo Mundo e o Ceticismo Moderno" In: Kriterion. Belo Horizonte, $\mathrm{n}^{\circ} 126$, Dez, pp.421-433.

. (2007) "Montaigne's view of skepticism and language in the Essais" In: D. A. KIBBEE (ed.) History of Linguistics 2005: Selected Papers from the Tenth International Conference on the History of the Language Sciences, pp. 103-111.

. (1994) "O Ceticismo Antigo: Pirronismo e a Nova Academia". In: Revista de Ciências Humanas, v.11, n.15, pp. 85-95.

. (2008) "Rústicos X Urbanos: O Problema do Insulamento e a Possibilidade de uma Filosofia Cética.” In: $O$ que nos faz pensar? Rio de Janeiro, n²4, outubro.

. (1997) “Sexto Empirico, "Hipotiposes Pirrônicas Livro I”(tradução). In: O que nos faz pensar? Rio de Janeiro, $\mathrm{n}^{\circ} 12$, setembro.

. (2009) "The Anthropological Argument: The Rediscovery of Ancient Skepticism in Modern Thought" In: J. C. LAURSEN, J. R. MAIA NETO \& G. PAGANINI (eds.) Skepticism in the Modern Age. Leiden: Martinus Nijhoff, pp.3753.

MARYKS, R. A. (2008) Saint Cicero and the Jesuits: The Influence of the Liberal Arts on the Adoption of Moral Probabilism. Aldershot: Ashgate. 
MATTHEN, M. (2014) "How to be sure: Sensory Exploration and Empirical Certainty". In: Philosophy and Phenomenological Research, vol. LXXXVIII, No. 1, pp. 38-69.

McKENNA, A. (2003) "Scepticism at Port-Royal: the perversion of Pyrrhonian Doubt" In: G. PAGANINI. The Return of Scepticism: From Hobbes and Descartes to Bayle, pp.249-66.

MEHL, É. (2001) "Dubito ergo sum: Descartes et le cogito des cartésiens", La lettre clandestine 10. In: A. McKENNA (ed.) La Lettre Clandestine, n.10 - 2001, pp. 4357.

NAESS, A. (1968) Scepticism. London; NewYork: Routledge and Kegal Paul.

NAYA, E. (2002) "Le Scepticisme au XVIe siècle: L'Ombre d'un Doute" in: G. ARTIGAS-MENANT \& A. McKENNA (eds.) Le lettre clandestine, n. 10 - 2001. Paris: Presses de 1'Université de Paris-Sorbonne, pp. 13-30.

. (2009) "Renaissance Pyrrhonism: A Relative Phenomenon" in: PAGANINI \& MAIA NETO (eds.) Renaissance Scepticisms. Dordrecht: Springer, pp.13-32.

(2002) Le vocabulaire des Sceptiques. Paris: Ellipses.

(2004) "Sextus à Gevève: la Réforme du doute". In: A. McKENNA \& P.-F. MOREAU. Libertinage et Philosophie au XVIIe siècle, n.8: Protestants, hérétiques, libertins. Publications de l'Université de Saint-Étienne, pp. 7-30.

NELSON, B. (1968) "The Early Modern Revolution in Science and Philosophy: Fictionalism, Probabilism, Fideism, and Catholic 'Prophetism'”. In: R. S. COHEN \& M. W. WARTOFSKY (eds.) Boston Studies in the Philosophy of Science, III. Dordrecht: D. Reidl, pp. I-40.

OLASO, E. de (1975) "El Significado de la Duda Esceptica". In: Revista Latinoamericana, vol. I, n. 1 , marzo. . (2011) “Os dois ceticismos de Vigário Saboiano” In: Skepsis, Ano IV, n. 6. . (2007) “Zetesis” In: Skepsis, Ano I, n.2

PAGANINI. G. (2008) Skepsis: le debat des modernes sur le scepticisme: Montaigne, Le Vayer Paris: Vrin.

. (2011) "A Querela sobre o ceticismo antigo e moderna: algumas reflexões sobre Descartes e o seu contexto" In: Skepsis, ano IV, n7, pp. 88-114.

(ed.). (2003) The Return of Scepticism. From Hobbes and Descartes to Bayle. Dordrecht: Kluwer Academic Publishers.

PASNAU, R. (2010) "Science and Certainty". In: R. PASNAU (Ed.) The Cambridge History of Medieval Philosophy. Cambridge: Cambridge University Press.

. (2002) The Cambridge Translations of Medieval Philosophical Texts. 3 Vols. Cambridge: Cambridge University Press.

(1997) Theories of Cognition in the later Middle Ages. Cambridge: Cambridge University Press. 
PENELHUM, T. (1986) "Sceptics, Believers, and Historical Mistakes". In: Synthese, Vol. 67, No. 1, The Role of History in and for Philosophy, pp.131-146.

PERRIN, C. (2008) "Descartes and the Legacy of Ancient Skepticism" In: J. BROUGHTON \& J. CARRIERO (eds.) A Companion to Descartes. Malden: Blackwell Publishing.

PIERCE, C.S. (1877) “The fixation of Belief” In: Popular Science Monthly, n. 12, November, pp. 1-15.

POPKIN, R. (2000) História do Ceticismo, de Erasmo a Spinoza. Tradução Danilo Marcondes. Rio de Janeiro: Francisco Alves.

. (1996) "Prophecy and Scepticism in the sixteenth and seventeenth Century" in: British Journal for the History of Philosophy, 4: 1, pp.1-20.

. (2003) The History of Scepticism, from Savonarola to Bayle. New York: Oxford University Press.

(1966) The Philosophies of the Sixteenth and Seventeenth Centuries. New York: The Free Press.

. (1987) "The Religious Background of Seventeenth-Century Philosophy" in: Journal of the History of Philosophy, Vol. 25, No 1, pp. 35-50.

. (1987) "The Role of Scepticism in Modern Philosophy Reconsidered" in: Journal of the History of Philosophy, Vol. 31, No 4, pp. 501-517.

. (1953) "The Sceptical Crisis and the Rise of Modern Philosophy: I" in: The Review of Metaphysics, Vol. 7, No. 1, pp. 132-151

. (1988) "Theories of Knowledge" In: C. SCHMITT The Cambridge History of Renaissance Philosophy. New York: Cambridge University Press, pp. 668-684.

POPPER, K. (1999) Conhecimento Objetivo. Belo Horizonte: Editora Itatiaia.

PORCHAT, O. (2005) "Empirismo E Ceticismo". In: Discurso (35), pp. 61-108.

RANNER, O. (2003) 'Plato and Aristotle on the Origin of Philosophy'. In: Abstracts of the Annual Meeting of the American Philological Association. Disponível em: apaclassics.org/sites/default/files/.../ranner.pdf Acesso: 12/12/13

REALE, G. (2011) Estoicismo, Ceticismo e Ecletismo. São Paulo: Edições Loyola.

SAARINEN, R. (1994) Weakness of the will in medieval thought: from Augustine to Buridan. Leiden; New York; kohl: Brill.

SAGAN, C. (1987) "The burden of Skepticism". Disponível em: http://www.csicop.org/si/show/burden_of_skepticism Acesso em: 10/02/2013

SCHMITT, C. (1983) Aristotle and the Renaissance. Cambridge \& London: Harvard University Press.

(1972) Cicero Scepticus. The Hague: Martinus Nijhoff.

. (1967a) Gianfrancesco Pico della Mirandola (1469-1533) and his critique of Aristotle. The Hague: Martinus Nijhoff.

- (1967b) "Giulio Castellani (1528-1586): A Sixteenth-Century Opponent of Scepticism" In: Journal of the History of Philosophy, Vol. 5, No 1, pp.15-39. 
(1963) "Henry de Ghent, Duns Scotus, and Gianfrancesco Pico on Illumination." In: Mediaeval Studies, Vol.25, pp.231-58.

. (1988) "John Wolley (ca. 1530-1596) and the first Latin translation of Sextus Empiricus, adversus logicos I" In: R. A. WATSON \& J. E. FORCE The Sceptical Mode in Modern Philosophy. Dordrecht: Martinus Nijhoff.

. (1983) "The Rediscovery of Ancient Skepticism in Modern Times" In: M. BURNYEAT (ed.) The Skeptical Tradition. Berkeley and Los Angeles: University of California Press, pp. 225-51.

. (1988) "The Rise of the Philosophical Textbook" In: C. SCHMITT (ed.) The Cambridge History of Renaissance Philosophy. New York: Cambridge University Press.

SCHREINER, S. E. (2011) Are you alone Wise? The search for certitude in the early modern era. New York: Oxford University Press.

SCHUSSLER, R. (2009) "Jean Gerson, moral certainty and the Renaissance of ancient Scepticism” In: Renaissance Studies Vol. 23 No. 4, pp. 445-462.

. (2005) "On the Anatomy of Probabilism". In: J. KRAYE \& R. SAARINEN (eds.) Moral Philosophy on the Threshold of Modernity. Dordrecht: Springer.

SCOTT, T. K. (1971). "Nicholas of Autrecourt, Buridan and Ockhamism" In: Journal of the History of Philosophy, Vol. 9, N. 1, January.

SEDLEY, D. (1983) "The Motivation of Greek Skepticism”. In: M. BURNYEAT (ed.) The Skeptical Tradition. Berkeley and Los Angeles: University of California Press, pp. 9-29.

. (1980) "The Protagonists" In: M. SCHOFIELD, M. BURNYEAT \& J. BARNES (eds.) Doubt and Dogmatism. Oxford: Oxford Clarendon Press, pp. 1-19.

SKINNER, Q. (2009) As fundações do pensamento político moderno. São Paulo: Editora Schwartz, ltda.

SKVIRSKY, A. (2012) "Kant e o pirronismo". In: O que nos faz pensar? Rio de Janeiro, $\mathrm{n}^{\circ} 32$, Dezembro. Especial sobre Kant. Org. Vera Cristina de Andrade Bueno.

STRIKER, G. "Academics versus Pyrrhonists, reconsidered” In: R. BETT (ed.) The Cambridge Companion to Ancient Scepticism. Cambridge: Cambridge University Press, pp. 195-207.

STROUD, B. (1984) The Significance of Philosophical Scepticism.Oxford: Oxford University Press.

SUTTON, R. B. (1953) “The Phrase Libertas Philosophandi” In: Journal of the History of Ideas, Vol. 14, No. 2, pp. 310-316.

THAGARD, P. (2004) "What is Doubt and When is it Reasonable?" In: Canadian Journal of Philosophy 34 (Supplement), pp. 391- 406.

THORSRUD, H. (2010) "Arcesilaus and Carneades". In: R. BETT (ed.) The Cambridge Companion to Ancient Scepticism. Cambridge: Cambridge University Press, pp. 58-80. 
VAN LEEUWEN. H.G. (1970) The problem of Certainty in English thought: 1630-1690. The Hague: Martinus Nijhoff.

VILLEY, P. (1908) Les sources et l'évolution des Essais de Montaigne, 2 vols. Paris: Gallica.

VOGT, K. M. (2012) “Appearances and Assent: Sceptical Belief Reconsidered”. In: The Classical Quarterly, 62, pp 648-663.

(no prelo) "Why Ancient Skeptics Don't Doubt the Existence of the External World: Augustine and the Beginnings of Modern Skepticism". In: Roman Reflections: Essays in Latin Philosophy, eds. Katharina Volk and Gareth Williams. NY: Oxford University Press. Disponível em: http://katjavogt.com/research/selected-papers/

Philosophy. "Ancient Skepticism" In: The Stanford Encyclopedia of http://plato.stanford.edu/archives/sum2014/entries/skepticism-ancient/ Acesso: 23.09.2014

WALDMAN, T. (1959) "Origins of the Legal Doctrine of Reasonable Doubt" in: Journal of the History of Ideas, vol. 20, n. 3, jun-sep.

WILLIAMS, B. (1978) Descartes: The Project of Pure Inquiry. London: Penguin Books. . "Descartes's Use of Skepticism" In: M. BURNYEAT (ed.) The Skeptical Tradition. Berkeley and Los Angeles: University of California Press, pp. 337-352.

. (1985) "Ethics and the Fabric of the World". In: HONDERICH (ed) Morality and Objectivity. A Tribute to J, L. Mackie. New York: Routledge \& Kegan Paul, pp. 203-214.

WILLIAMS, M. (1986) "Descartes and the Metaphysics of Doubt" In: A. O. RORTY (ed.) Essays on Descartes' Meditations. Berkeley: University of California Press, pp.117-39.

. (2010) "Descartes's transformation of the sceptical tradition" in: R. BETT (ed.) The Cambridge Companion to Ancient Scepticism. Cambridge: CUP, pp.288-313.

. (1988a) "Epistemological Realism and the basis of Skepticism" in: Mind, New Series, Vol. 97, No. 387, pp. 415-439

. (1988b) "Scepticism without Theory" in: The Review of Metaphysics, Vol. 41, No. 3, pp. 547-588

. (2013) "Skepticism, Evidence and Entitlement" in: Philosophy and Phenomenological Research, Vol. LXXXVII No. 1, pp. 36-71.

(1996) Unnatural Doubts. New Jersey: Princeton University Press.

WITTGENSTEIN, L. (1969) Da Certeza. Lisboa: Edições 70.

WOODRUFF, P. “Aporetic Pyrrhonism”. In: Oxford Studies in Ancient Philosophy, n.6, pp. 139-168.

ZELLER, E. (2010) The Stoics, Epicureans and Sceptics. Lexington: Forgetten Books. 